UNIVERSIDADE DE SÃO PAULO

INSTITUTO DE GEOCIÊNCIAS

\title{
ASPECTOS MINERALÓGICOS E ECONÔMICOS DE DIAMANTES \\ DAS REGIÕES DE CHAPADA DOS GUIMARÃES, POXORÉU, DIAMANTINO, PARANATINGA E ALTO PARAGUAI, MATO GROSSO
}

IEDE TEREZINHA ZOLINGER

Orientador: Prof. Dr. Darcy Pedro Svisero

DISSERTAÇÃO DE MESTRADO

COMISSÃO JULGADORA

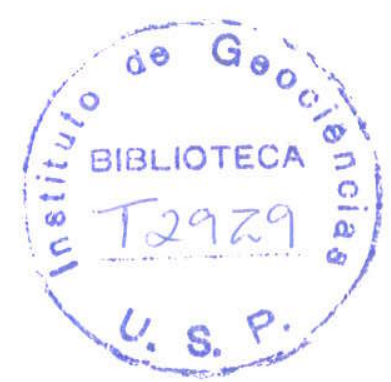

Nome

Presidente: Prof. Dr. Darcy Pedro Svisero

Examinadores: Prof. Dr. Daniel Atencio

Dr. Luiz Agusto Bizzi

SÃO PAULO

Assinatura

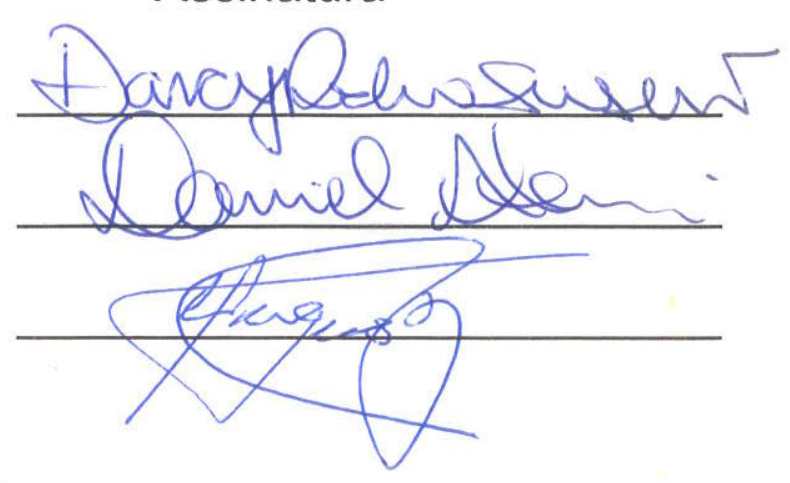
2000 
UNIVERSIDADE DE SÃO PAULO

INSTITUTO DE GEOCIENCIAS

\section{ASPECTOS MINERALÓGICOS E ECONÔMICOS DE DIAMANTES DAS REGIÕES DE CHAPADA DOS GUIMARĀES, POXORÉU, DIAMANTINO, PARANATINGA E ALTO PARAGUAI, MATO GROSSO}

lede T. Zolinger

Orientador: Prof. Dr. Darcy Pedro Svisero

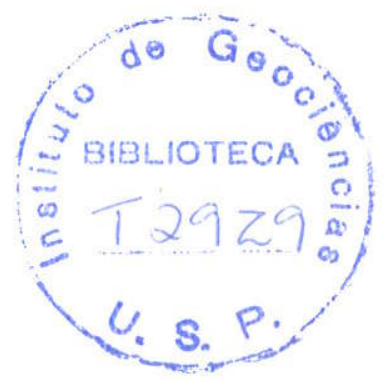

DISSERTAÇÃO DE MESTRADO

Programa de Pós-Graduação em Mineralogia e Petrologia

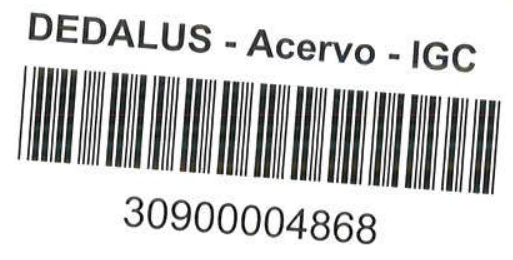

SÃO PAULO

2000 
Para mintia família e amigos.

Valeu! 


\section{AGRADECIMENTOS}

Ao término desta Dissertação de Mestrado desejo expressar os meus mais sinceros agradecimentos às diversas pessoas e instituições listadas a seguir que me auxiliaram durante a realização deste trabalho.

Assim sendo, agradeço o Prof. Dr. Darcy Pedro Svisero pela orientação, dedicação, apoio e compreensão dispensados durante as diversas fases da execução desse trabaho; o Prof. Dr. Ricardo K. Weska da Universidade Federal de Mato Grosso, que apoiou o meu ingresso no Curso de Pós-graduação do IG/USP, auxiliou nas atividades de campo e na interpretação da geologia regional; o Sr. Paulo Traven que colocou a minha disposição diversos lotes de diamantes tornando possível a obtenção dos dados mineralógicos; e à Coordenação do Pessoal de Nível Superior (CAPES) pela concessão da bolsa de pesquisa durante a realização dessa dissertação.

Sou grata à minha amiga e colega de profissão MSc. Rosana Peporine Lopes, que auxiliou na correção do texto e sugeriu mudanças no decorrer deste trabalho; ao Prof. Dr. José B. Madureira Filho por apresentar sugestões no capítulo referente à gemologia do diamante; ao MSc. Marcelo Monteiro da Rocha, aluno de Doutorado do Departamento de Geologia Sedimentar e Ambiental, que auxiliou na preparação e na interpretação dos dados estatísticos; o MSc. William Salum Filho pelo auxílio na elaboração das figuras que compõem o capítulo quinto.

Da mesma forma agradeço o Dr. Isaac J. Sayeg e a Srta. Camila Michelin do Laboratório de Microscopia Eletrônica do Departamento de Geologia Sedimentar e Ambiental, que auxiliaram nos trabalhos de obtenção das eletromicrografias; o Prof. Dr. Gergely Szabó e a Sra. Angélica Morente, pelo auxílio durante as análises realizadas no Laboratório de Óptica do Departamento de Mineralogia e Geotectônica; o Prof. Dr. Excelso Ruberti, ex-coordenador do Programa de Pós-Graduação em Mineralogia e Petrologia, pelas iniciativas que beneficiaram a pós-graduação do Programa de Mineralogia e Petrologia; e o Prof. Dr. Yushiro Kihara pela colaboração durante a obtenção de dados de difração de raios $X$.

Sou grata também a todos os colegas de Programa Carmem Nunes (Xitah), Lucelene Martins (Vaudemar), Klaus Petersen Júnior, Fernando Freitas (Pobremah), Gustavo Vilela (Troglô), Gilson Guimarães, Howard Peter K. Davies, Marco Aurélio B. Martin, Prof. Dr. Caetano Juliani, Prof. Dr. Fábio Ramos Dias de Andrade, Prof. Dr. 
Francisco Rubens Alves e Prof. Dr. Daniel Atencio, pela companhia durante o período de mestrado e pelo convívio nos inúmeros finais de semana.

Não poderia deixar de agradecer às amigas Annabel Pérez Aguilar, Maria Manuela Galvão Monteiro Capovilla, Mirian Shinzato e Sandra Iwata, que comigo conviveram nos últimos anos em nossa sala de trabalho, pelas discussões proveitosas e soluções oferecidas, tanto em geologia como em outros assuntos.

Às funcionárias da Biblioteca Sras. Brenda Mascarenhas, Érica do Nascimento, Maristela Prestes Severino e Maria Aparecida Bezerra, que atenderam com profissionalismo todas as consultas efetuadas; os funcionários das Secções de PósGraduação Sras. Ana Paula Cabanal e Magali Fernảndes Rizzo e o Sr. Tadeu Gaggiano, que da mesma forma atenderam sempre com cortesia e trataram com responsabilidade os assuntos referentes à Pós-graduação; o Sr. Marcos Mansueto funcionário da Microssonda e a Sra. Sandra Andrade do Laboratório de Química, que auxíliaram no tratamento das amostras; os funcionários do Setor de Laminação, Srs. Cláudio Hopp, Paulo Roberto Molinaro, Paulo Augusto Morgato, Luiz Cláudio Nogueira que adaptaram uma lâmina para analisar os diamantes sob imersão, os meus agradecimentos.

Agradeço também as Sras. Nícia M. B. Zalaf e Sonia Gomes Costa Vieira do Departamento de Mineralogia e Geotectônica e à Sra. Denise C. M. Cristovan, exsecretária do antigo Programa de Mineralogia e Petrologia, por toda a atenção dispensada durante este trabalho; os funcionários da Gráfica, Srs. Claudionor Barbosa e Edmir de Oliveira foram responsáveis pela encadernação dos volumes finais dessa dissertação; e o Sr. Jaime S. Marcos, que preparou parte do material fotográfico utilizado.

A todos os profissionais e amigos, que de uma forma ou de outra colaboraram neste trabalho e que por descuido não tenham sido mencionados, apresento os meus mais sinceros agradecimentos. 


\section{SUMÁRIO}

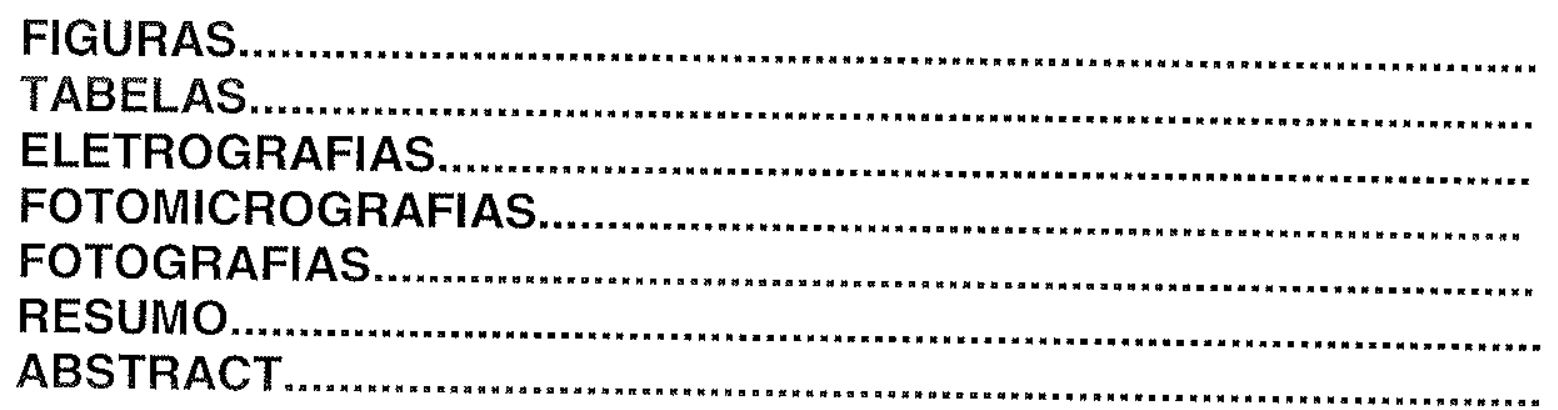

\section{INTRODUÇÃO}

1.1. Diamante no Estado de Mato Grosso

1.2. Localização geográfica das áreas.

1.3. Aspectos fisiográficos

1.3.1. Clima

1.3.2. Vegetação.

1.3.3. Drenagem

1.3.4. Relevo.

1.4. Objetivos

2. MATERIAIS E MÉTODOS

2.1. Trabalhos de campo

2.1.1. Registro dos dados obtidos

2.2. Trabalhos de laboratório

2.2.1. Preparação das amostras.

2.2.2. Microscopia óptica.

2. 3. Microscopia eletrônica........................................................... 19

2.

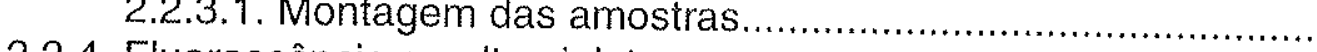

2.2.4. Fluorescência ao ultravioleta............................................. 21

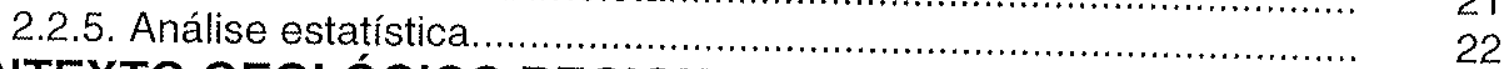

3. CONTEXTO GEOLÓGICO REGIONAL .......................................

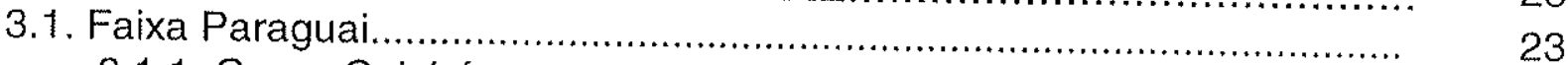

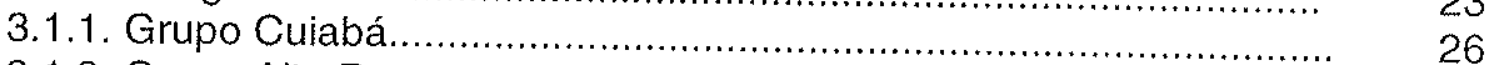

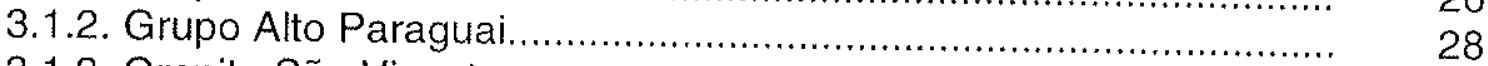

3.1.3. Granito São Vicente........................................................ $\quad 30$

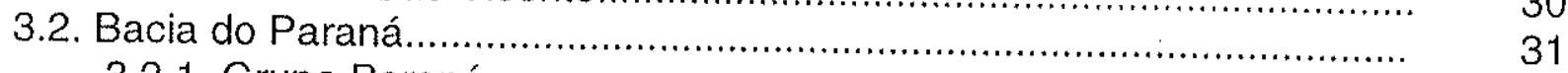

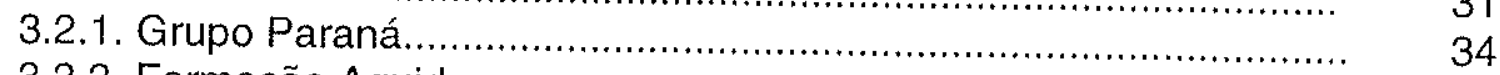

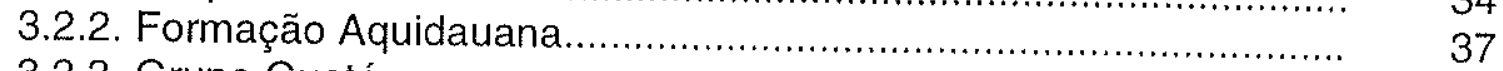

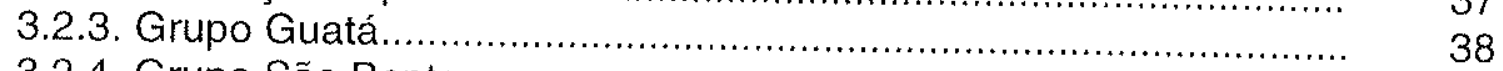

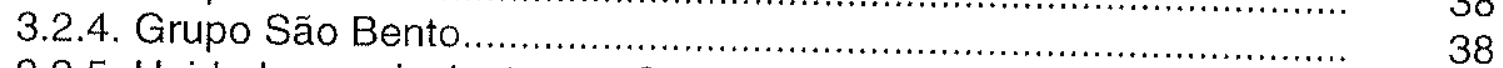

3.2.5. Unidades equivalentes ao Grupo Bauru..................................... 40

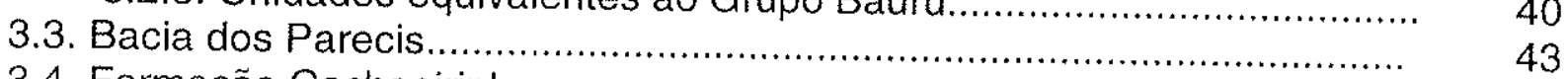

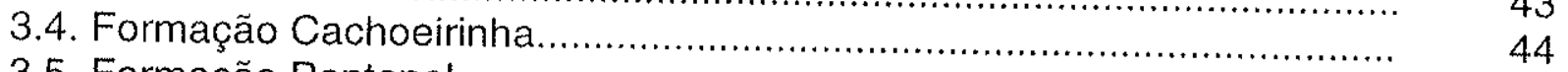

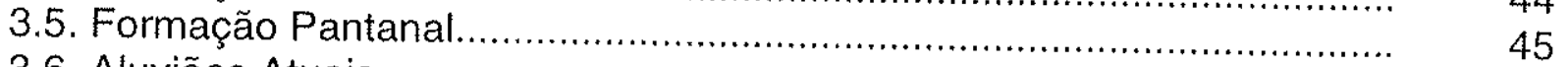

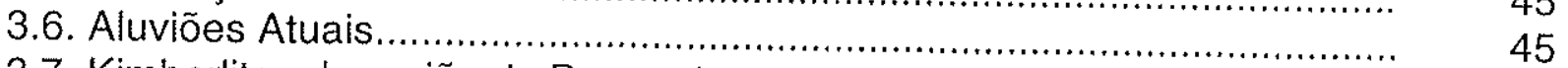

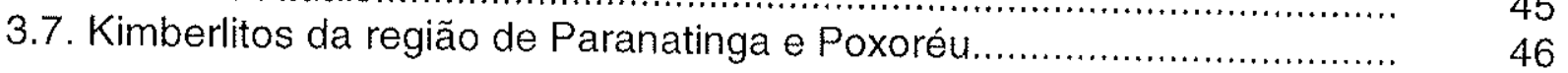


3.8. Depósitos Diamantíferos.

3.8.1. Chapada dos Guimaräes

3.8.2. Poxoréu.

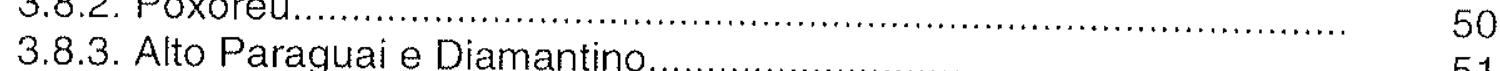

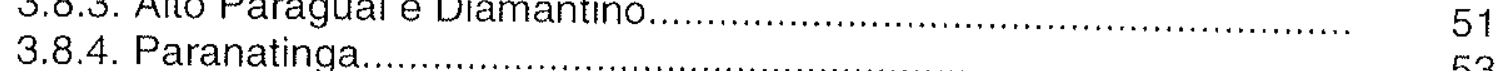

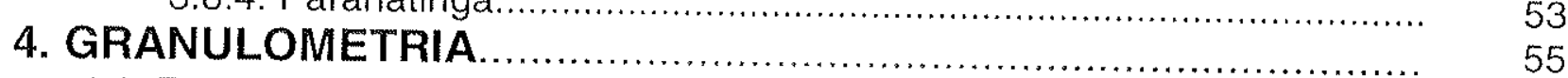

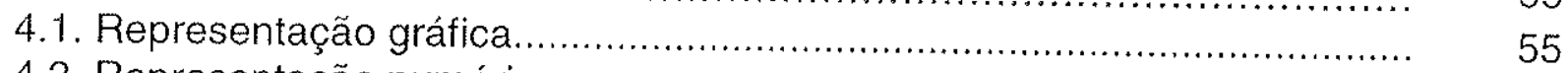

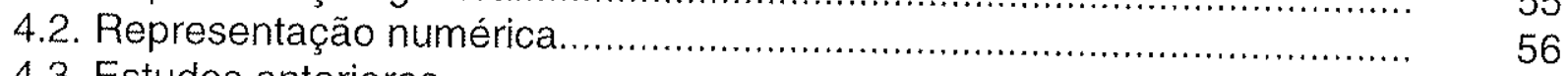

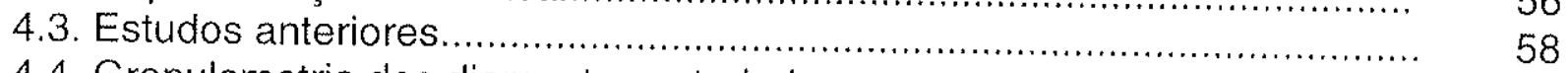

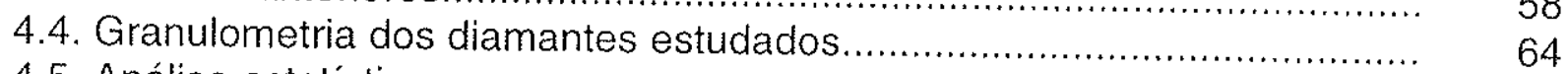

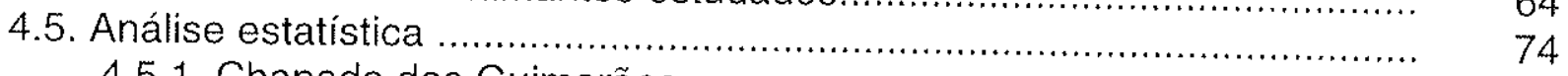

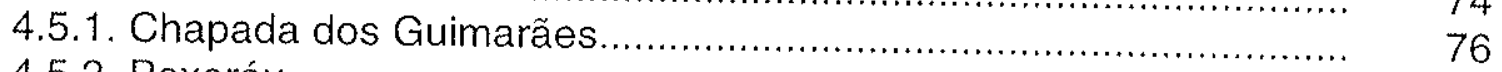

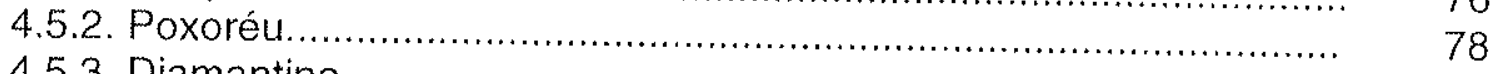

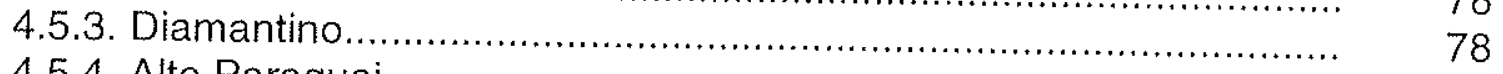

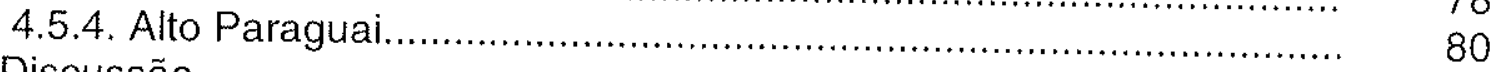

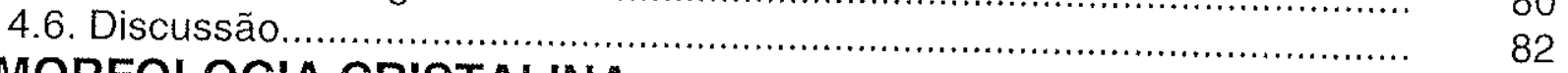

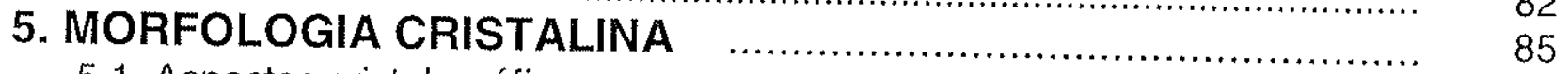

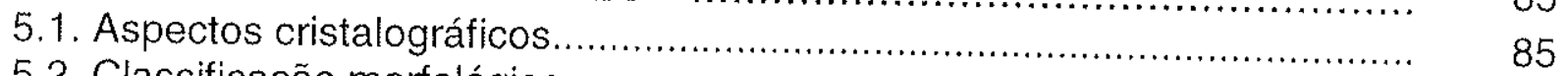

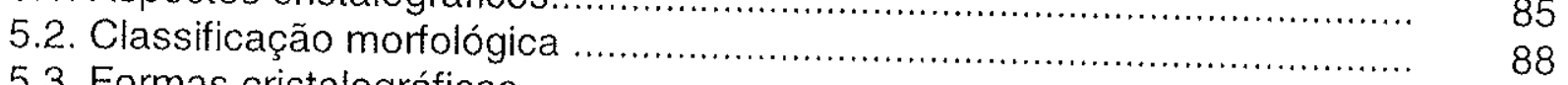

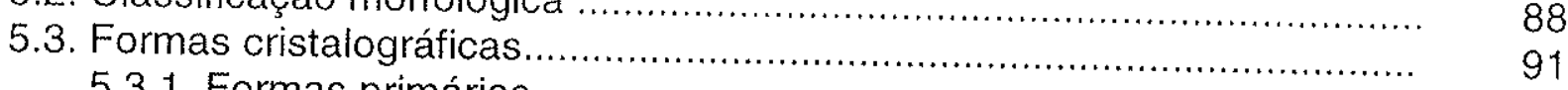

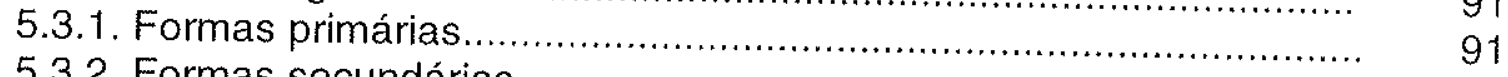

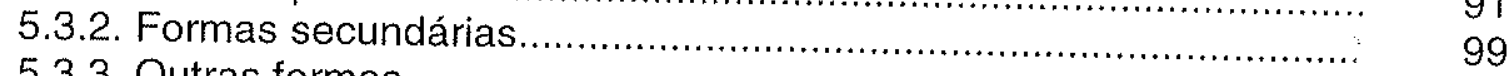

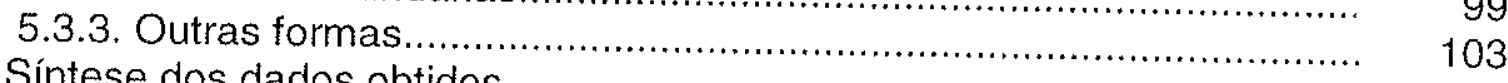

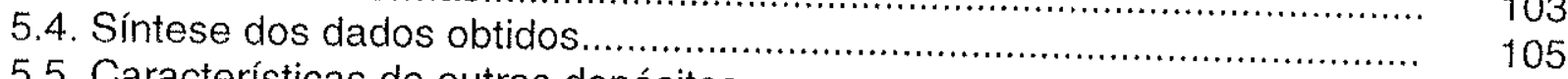

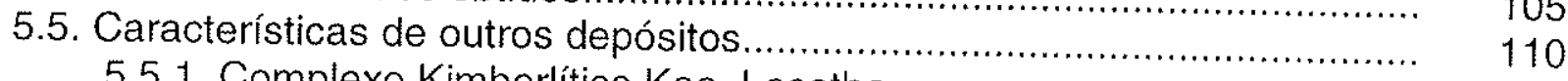

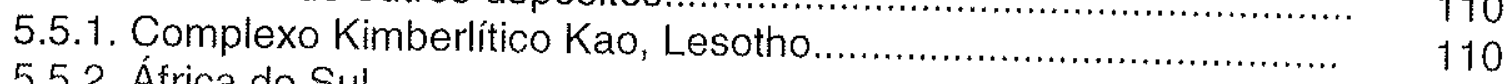

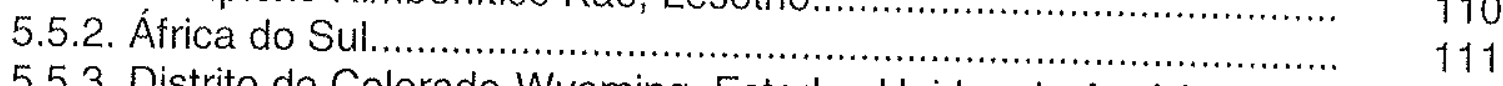

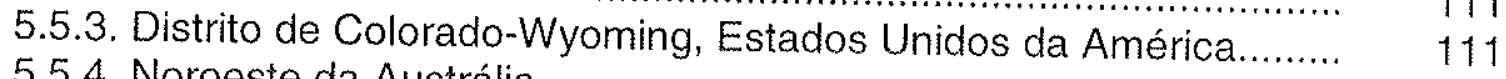

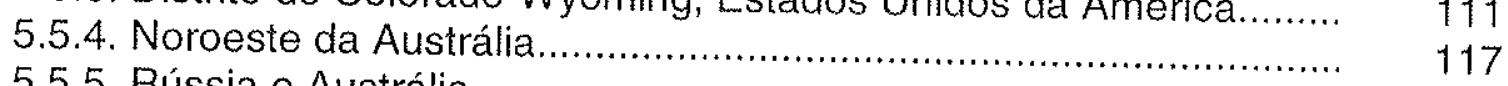

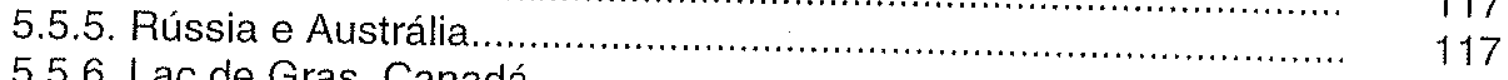

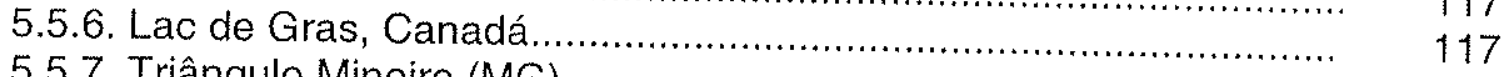

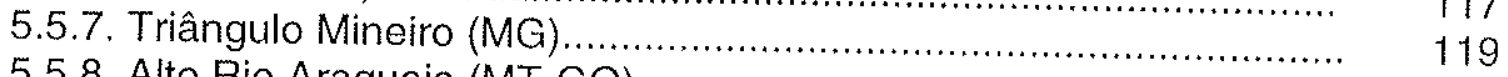

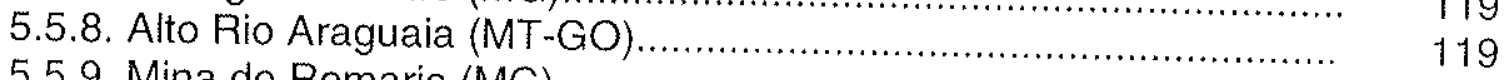

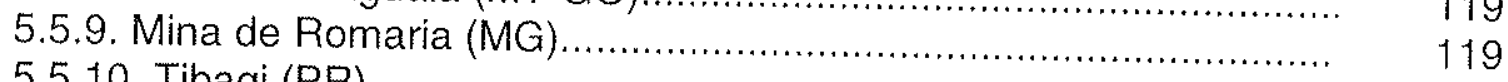

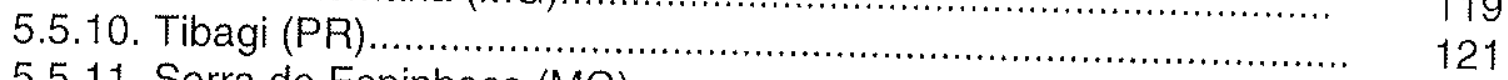

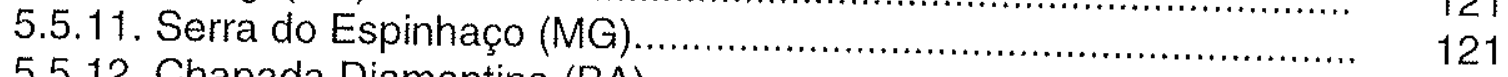

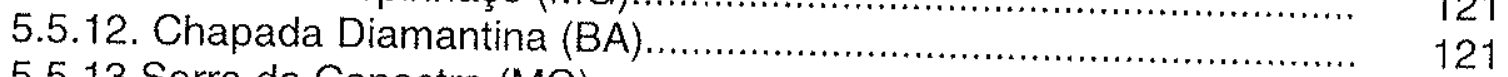

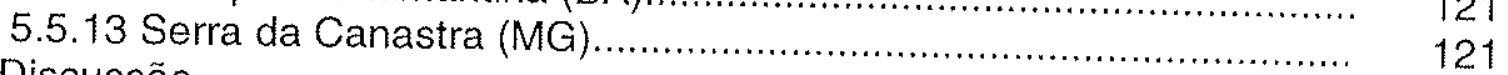

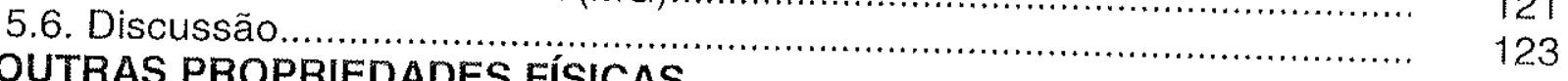

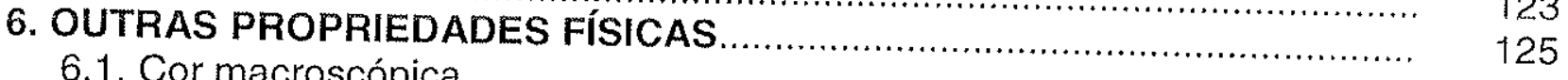

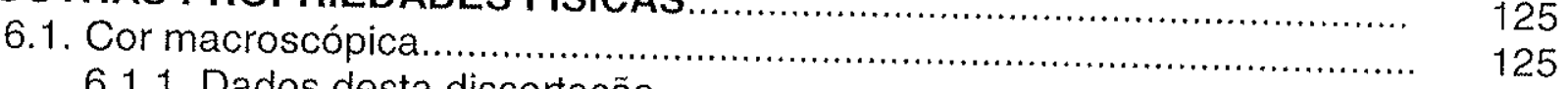

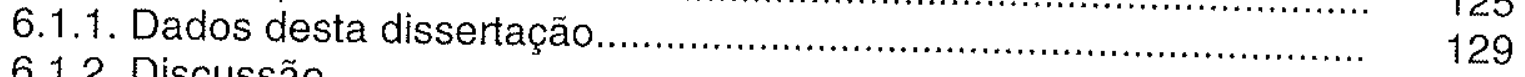

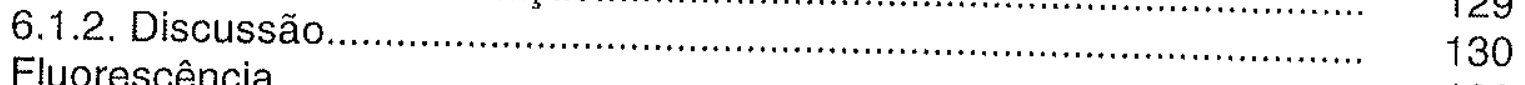

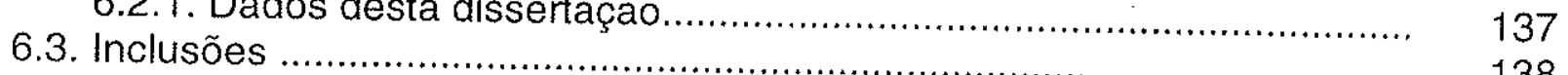

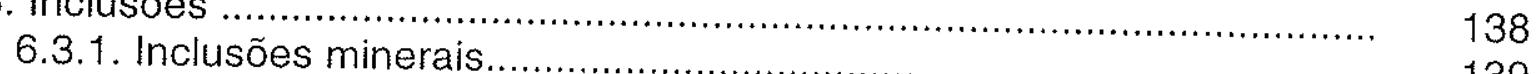

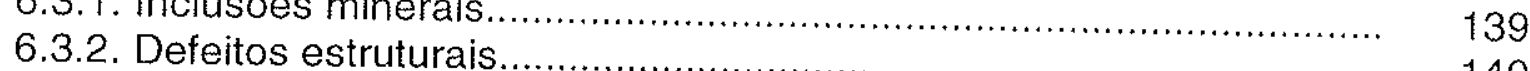

6.3.3. Dados desta dissertação..................................................... 140

7. CLASSIFICAÇÃO COMERCIAL DO DIAMANTE 


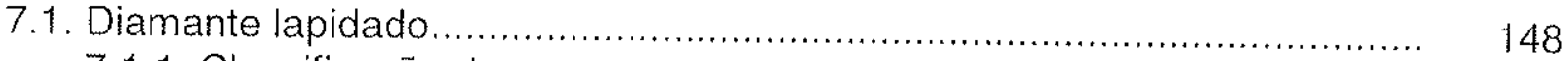

7.1.1. Classificaçäo da cor................................................... 149

7.1.2. Classificação da pureza ....................................................... 151

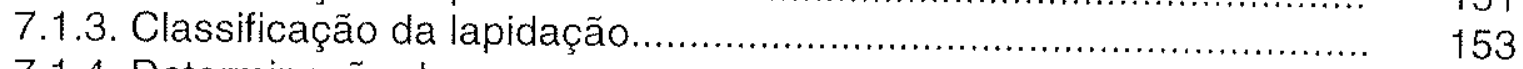

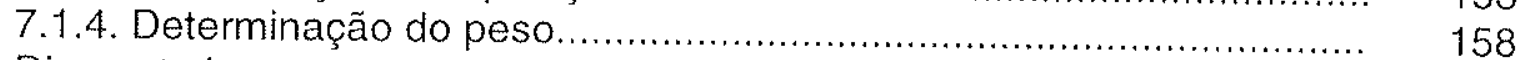

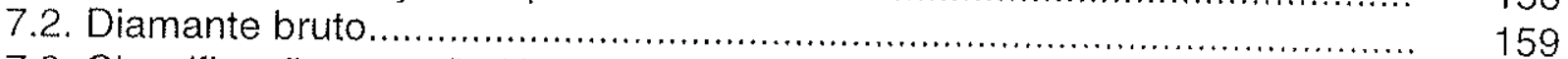

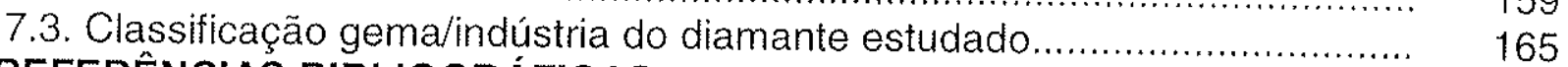

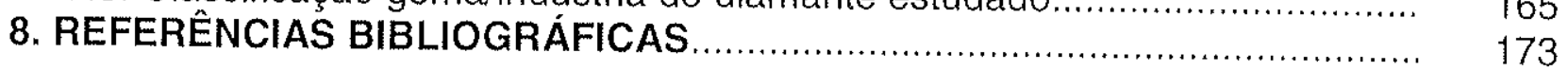




\section{ÍNDICE DE ILUSTRAÇÕES}

\section{ÍNDICE DE FIGURAS}

Figura 1.1 - Localização geográfica da área estudada .................................. 04

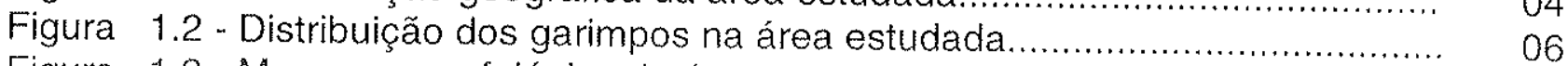

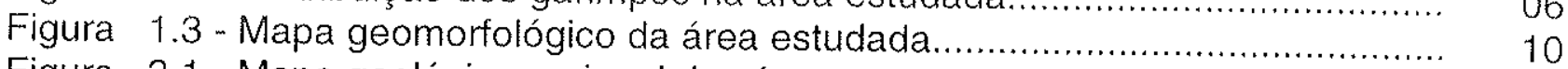

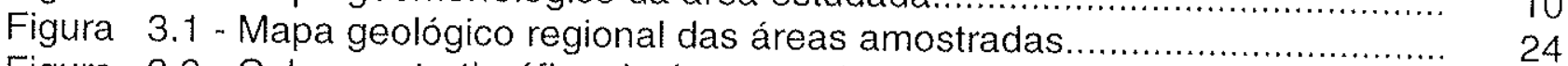

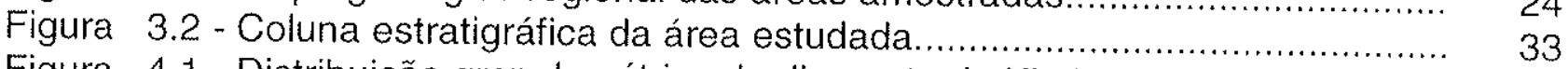

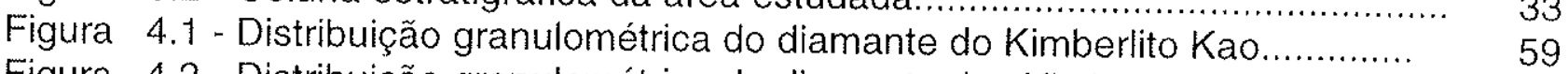

Figura 4.2 - Distribuição granulométrica do diamante dos Kimberlitos Sloan 1 e 2.. $\quad 61$

Figura 4.3 - Ídem em função da porcentagem dos cristais................................ 61

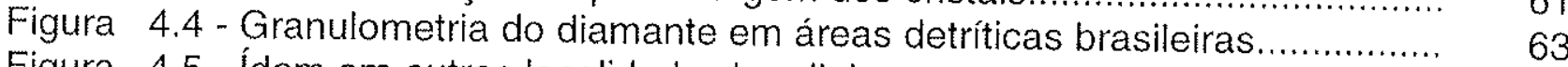

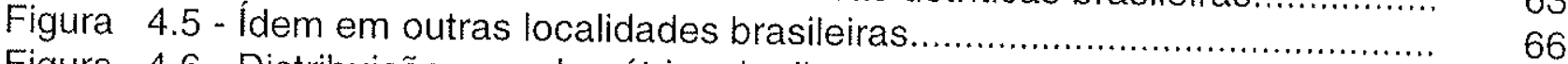

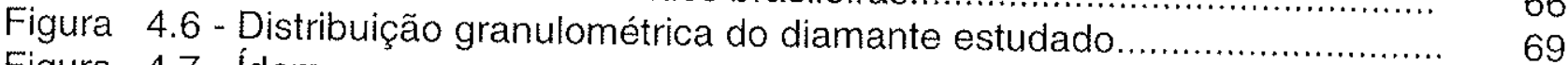

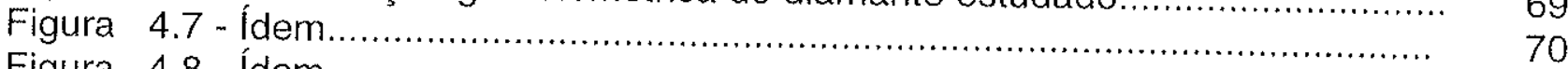

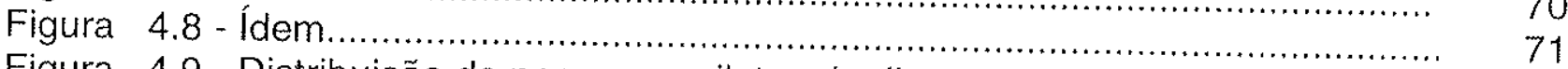

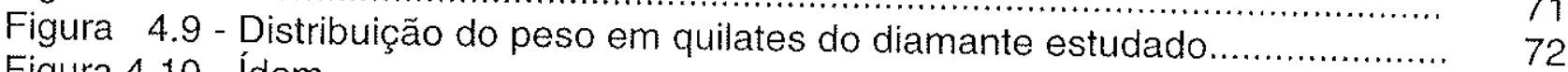

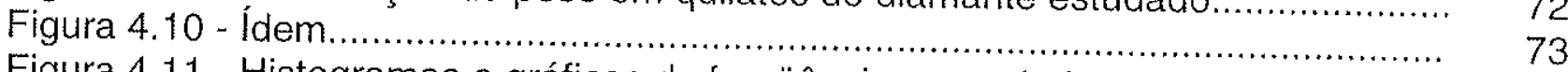

Figura 4.11 - Histogramas e gráficos de freqüência acumulada de distribuição $\quad 77$

Figura 4.12 - Ídem. granulométrica do diamante estudado

Figura 4.13 - Ídem

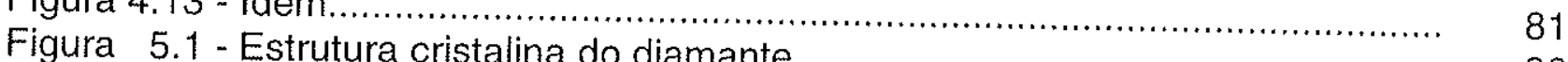

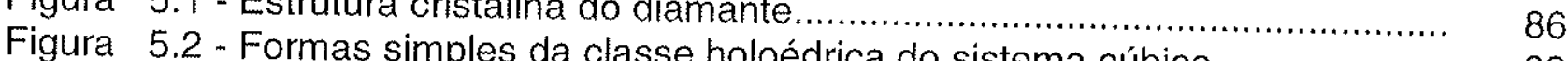

Figura 5.3 - Formas combinadas classe holoedrica do sistema cúbico.................. 89

Figura 5.4-Evolução morfológiána cúbico.............. 90

Figura 5.5 - Evolução morfológica a partir do octaedro primário........................... 100

Figura 5.6 - Distribuição das forma

Figura 5.7 - Ídem.................... 107

Figura 5.8 - Critérios usados por Whitelock.................................................. 108

Figura 5.9 - Distribuição da morfor

Figura 5.10 - Distribuição da morfologia no Kimberlito Kao ............................... 112

Figura 5.11 . Critérios usados por

Figura 5.12 - Distribuição da morfor et al. (1994) na classificação morfológica... 115

Figura 5.13 - Morfologia do diamante do Kimberlítico Sloan 1 e 2.................... 114

Figura 5.14 - Formas cristalográficas em lamproítos do Colorado-Wyoming......... 116

Figura 5.15 - Formas cristalinas em microdiamantos da Austrália......................... 118

Figura 5.16 - Morfologia de diamantes detríticos de Yakútia e Austrália. ........ 118

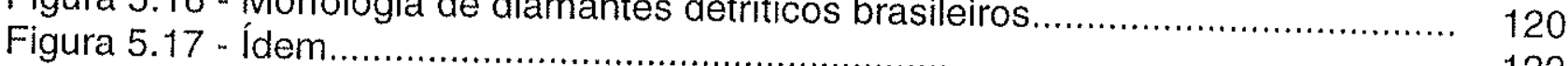

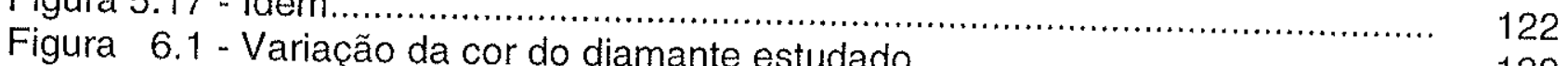

Figura 6.2 - Ídem, em função da granulometria

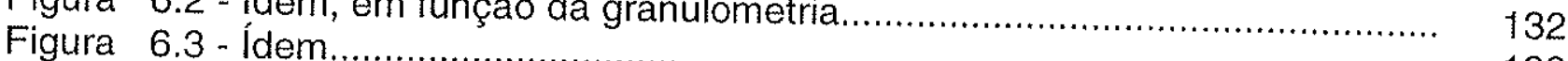

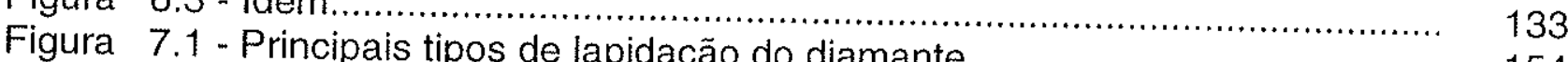

Figura 7.2 . Influência da morfologia ņa do diamante ................................... 154

Figura 7.3 - Relação gema/indústria na ároveitamento do diamante.................. 156

Figura 7.4 - Relação gema/indústria de aureas estudadas................................. 168

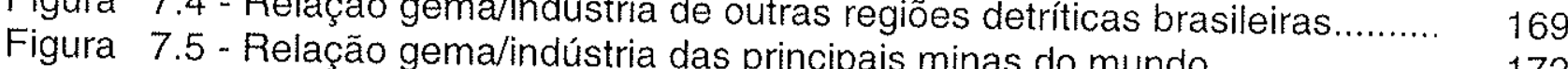




\section{ÍNDICE DE TABELAS}

Tabela 2.1 - Sintese das propriedades físicas do diamante.......................... 16

Tabela 2.2 - Esquema da tabela usada na caracterização de lotes de diamante.. $\quad 17$

Tabela 4.1 - Constantes granulométricas do sistema ANTWERP ..................... 67

Tabela 4.2 - Dados da distribuição granulométrica dos diamantes amostrados.... 68

Tabela 4.3 - Dados estatísticos dos diamantes amostrados........................... 75

Tabela 5.1 - Formas cristalográficas dos diamantes estudados............................. 106

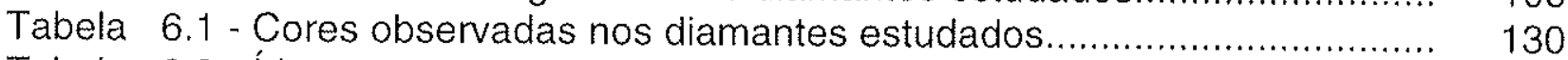

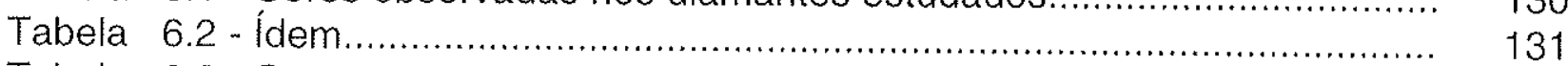

Tabela 6.3 - Comparação da cor entre diamantes detríticos e kimberlíticos......... 135

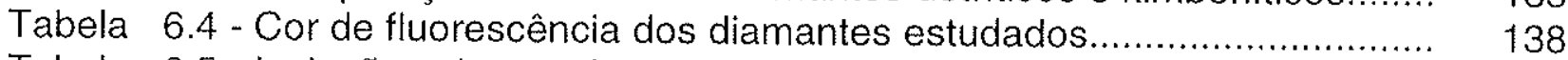

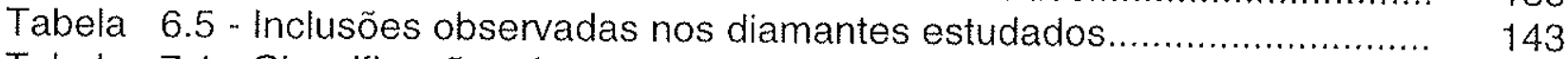

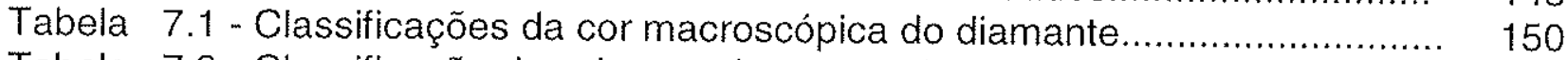

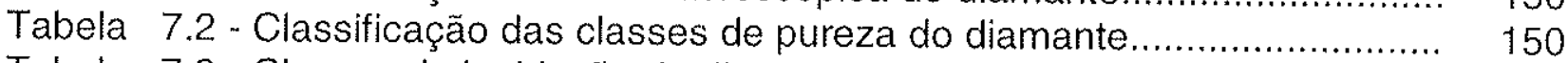

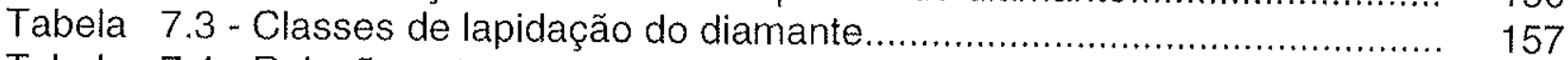

Tabela 7.4 - Relação entre o peso e o diâmetro do diamante lapidado...................... 157

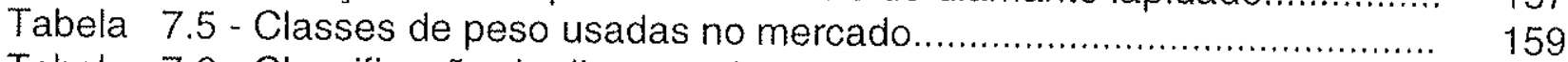

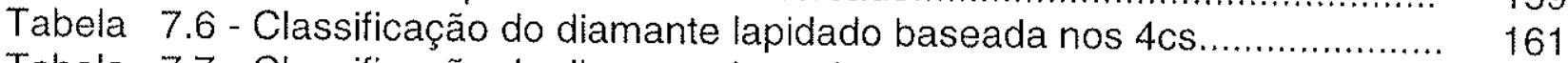

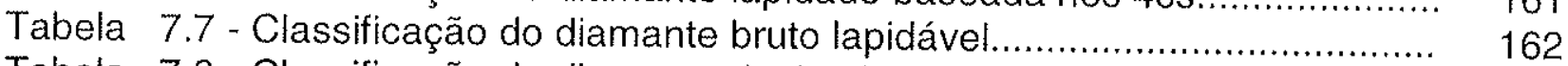

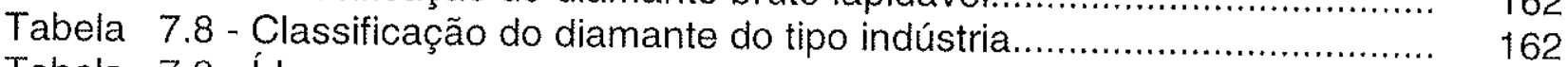

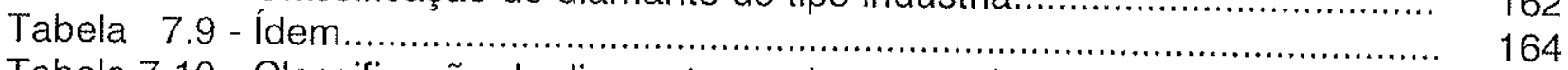

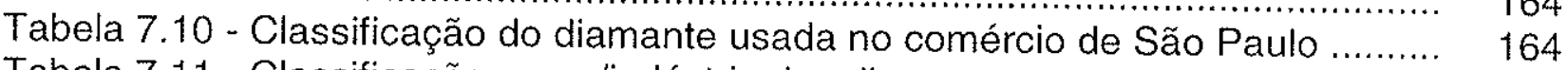

Tabela 7.11 - Classificação gema/indústria dos diamantes estudados................... 166

Tabela 7.12 - Espectos geológicos e econômicos de diamantes dos principais 171

\section{ÍNDICE DE ELETROGRAFIAS}

Eletromicrografia 5.1 - Formas octaédricas de crescimento ........................... 92

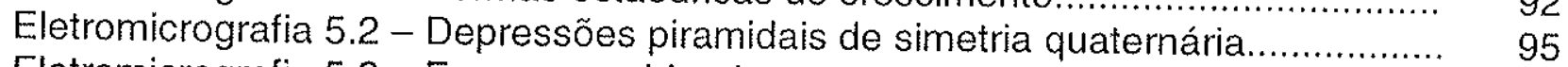

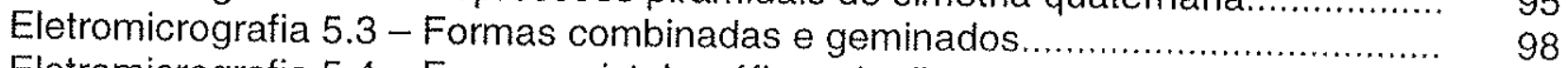

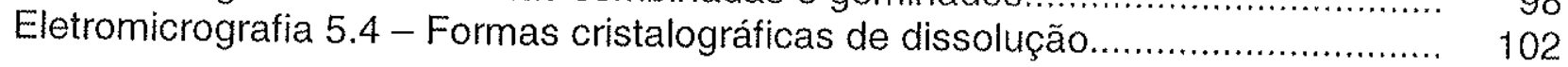

\section{ÍNDICE DE FOTOMICROGRAFIAS}

Fotomicrografia 5.1 - Aspectos morfológicos dos cristais octaédricos................. 92

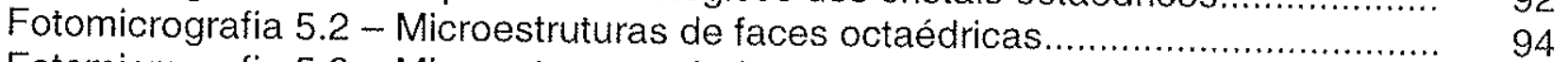

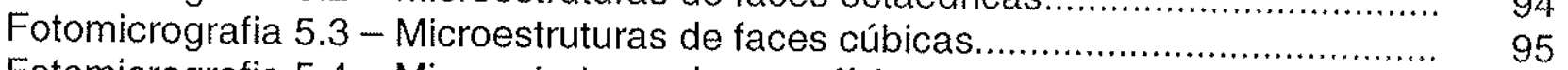

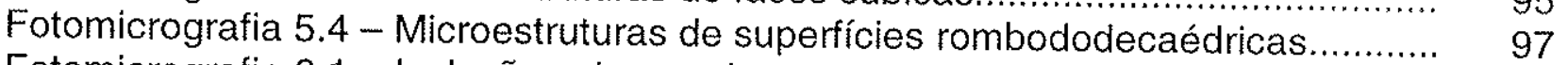

Fotomicrografia 6.1 - Inclusões observadas nos diamantes estudados.................. 144

Fotomicrografia 6.2 - Inclusões em um diamante lapidado................................. 1445

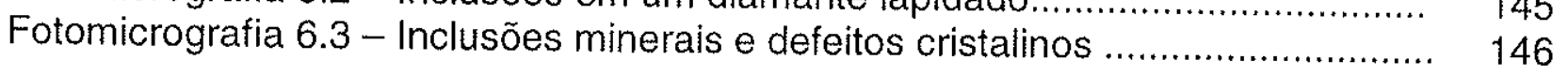

\section{ÍNDICE DE FOTOGRAFIAS}

Fotografia 6.1 - Coleção de diamantes fantasia. 


\section{RESUMO}

Neste trabalho foram estudados 4.198 cristais de diamantes provenientes de garimpos em aluviões dos Municípios de Chapada dos Guimarães, Poxoréu, Diamantino, Paranatinga e Alto Paraguai, Mato Grosso. Os diamantes foram analisados e classificados com base em suas características granulométricas, morfológicas, relação gema/indústria e outras propriedades físicas tais como a cor macroscópica, inclusões, estruturas de superfície. As propriedades descritas foram comparadas, sempre que possível, com trabalhos realizados com diamantes provenientes de aluviões de diferentes regiões do Brasil, bem como, com diamantes provenientes de kimberlitos e lamproítos de outros países tais como áfrica do Sul, Lesotho, Austrália, Rússia, Estados Unidos da América e Canadá.

A granulometria dos diamantes revelou em todas as regiões amostradas uma distribuição polimodal, contrastante com o padrão unimodal aparentemente existente em kimberlitos. Esse comportamento polimodal provavelmente estaria indicando que mais de uma fonte kimberlítica e/ou de sedimentos diamantíferos retrabalhados, forneceriam diamantes para os depósitos amostrados.

A análise da morfologia cristalina mostrou que ocorre um predomínio em todas as áreas estudadas do hábito rombododecaédrico. No entanto, percebe-se que fragmentos de clivagem, irregulares e agregados são também representativos. Cristais de hábito cristalino octaédrico, cúbico e intermediário entre octaedro e rombododecaedro, bem como formas combinadas, apresentaram representatividade variada entre as regiões. As estruturas de superfície observadas nas faces dos cristais foram trígonos, depressões quadráticas, degraus abaulados, microdiscos, estruturas em rede e estruturas de crescimento.

O estudo da cor macroscópica dos diamantes revelou que a maioria dos cristais são incolores, sendo seguidos pelas cores amarela e castanha. Outras como o verde, rosa e lilás são mais raras. Quanto ao comportamento sob luz ultravioleta, os diamantes exibiram principalmente luminescência azul, seguida das cores rosa, amarela, cinza e verde. As inclusões mais comuns nos diamantes foram defeitos cristalinos na forma de manchas pretas de forma placóide, dispostos paralelamente aos planos de clivagem octaédricos, além de minerais prismáticos e incolores que provavelmente correspondem a olivina. 
A classificação dos diamantes nos tipos gema e indústria revelou que os cristais gemológicos predominam em todas as regiões amostradas. Este fato é comum em se tratando de diamantes aluvionares, pois cristais portadores de inclusões e defeitos estruturais são destruidos devido a menor resistência mecânica ao transporte. 


\section{ABSTRACT}

During this work we carried out a mineralogical investigation based on 4.198 detritic diamond representative of diggings from the municipalities of Chapada dos Guimarães, Poxoréu, Paranatinga, Diamantino e Alto Paraguai, Mato Grosso State. Several parcels of diamond were classified in relation to their crystalline morphology, microstructures, granulometry, color, internal inclusions, fluorescence and gem/industry ratio. Following its characterization the results were correlated to their counterparts of diamonds from kimberlites of South Africa, Lesotho, United States of America, Russia and Australia, as well as placers from Brazil.

Concerning the granulometry all studied diamonds revealed a polimodal distribution which was in contrast to the unimodal pattern observed in kimberlites. This result suggests that the sources of the sampled deposits are related either to more than one kimberlite source, and/or to older regional placer depositis.

The main crystallographical feature was the dominance of the dodecahedral crystals which was followed by transitional forms between octahedral and dodecahedral, cleavage fragments, irregular and aggregate. Other crystallographical forms such as octahedral, cube, combinations between octahedral, cube and dodecahedral, pseudo-hexatetrahedral and polycrystalline diamond (carbonado and ballas) are rare. Among the microstructures it have been observed trigons on the flat octahedral faces, terraces, hillocks, micro-disc and network pattern on the rounded dodecahedral surfaces, and tetragonal etch pits on the cube surfaces.

Diamond color was broadly classified into colorless, brown, yellow, gray and other categories. The majority are colorless with less amounts of brown, yellow and gray crystals. Other rarer observed colors included green, pink and purple. Under ultraviolet radiation some diamonds were blue luminescent while a small group displayed pink, yellow, green and gray colors. Optical studies revealed that black spots were the most common inclusion inside the diamonds. Moreover, some prismatic colorless and birrefringent mineral inclusions were present and may correspond to olivine.

Concerning the ratio gem/industry most of the samples are gem-type diamonds. In a general sense the physical and the morphological pattern observed in the sampled localities agree with other detritic areas of Brazil. Such pattern was predicted since 
diamond is selected during its mechanical transport. Megadiamonds as well as fancy stones have not been observed during this work. 


\section{INTRODUÇÃO}

A palavra diamante deriva-se do grego $\alpha \delta \alpha \mu \alpha \xi$ (adamas), que significa invencivel, pois pensava-se antigamente que esse mineral fosse indestrutível. Posteriormente, percebeu-se que o diamante possui uma dureza extrema, não podendo ser riscado por nenhuma outra substância, mas por outro lado, possui clivagem perfeita podendo ser fragmentado sob impacto. Conhecido desde a mais remota Antiguidade, o diamante vem sendo garimpado na Índia desde aproximadamente 2000 a.C. Durante o periodo da Idade Média essa gema foi valorizada abaixo do rubi e esmeralda; ocupando entre os lapidários medievais a $17^{a}$ posição em importância. Contudo, com o desenvolvimento das técnicas de lapidação e do polimento, o diamante passou a ocupar um lugar importante na lista das principais gemas do mundo.

O progresso resultante das viagens marítimas logo após o Renascimento ativou o comércio do diamante no mundo. $\mathrm{Na}$ metade do século 17 o viajante francês Tavernier introduziu o uso do diamante gemológico nas cortes européias, fato que incentivou ainda mais a procura dessa gema. Em 1725, o diamante foi descoberto em garimpos da Vila Tejuco, localizada no Estado de Minas Gerais, cujo progresso ulterior daria origem à cidade de Diamantina (Leonardos 1956). Algumas décadas depois o diamante foi descoberto em Mato Grosso e mais tarde em outros estados brasileiros. A produção aumentou rapidamente e o Brasil tornou-se o maior produtor mundial durante mais de um século.

Por volta de 1866 foram descobertas ocorrências aluvionares nas cabeceiras dos Rios Orange e Vaal no centro do território da República Sul Africana, fato que provocou uma corrida de garimpeiros na região (Bruton 1978). Em 1871 o diamante foi finalmente descoberto in situ em uma rocha vulcânica que recebeu o nome de kimberlito (Mitchell 1986). Em pouco tempo, a África do Sul tornou-se o principal produtor mundial passando a controlar a produção e a distribuição do diamante através do cartel De Beers. Atualmente, o Brasil é um produtor pequeno, ocupando uma posição modesta entre os produtores mundiais (DNPM 1998), contribuindo com menos de $1 \%$ do montante mundial. Os principais produtores da atualidade são a Rússia, Austrália, África do Sul e Zaire, entre outros (Janse 1995).

Após a Revolução Industrial passou a ser utilizado de forma crescente como 
material de corte e polimento, tendo em vista sua alta dureza (10 na escala relativa de Mohs), a maior conhecida entre todas as substâncias naturais e sintéticas. Entre outras propriedades especiais reconhecidas nos últimos anos, destacam-se a alta condutividade térmica, maior do que três vezes a do cobre, tornando o diamante um excelente dissipador de calor em componentes eletrônicos (Trautman et al. 1998). Outra propriedade importante é a alta condutibilidade elétrica de certos diamantes contendo impurezas de boro, tornando-os excelentes semicondutores (Harris 1987). Seu emprego na indústria diversificou-se nas últimas décadas a ponto de ser usado como um indicador do desenvolvimento tecnológico dos países.

A produção de diamante natural deverá alcançar esse ano um valor em torno de 125 milhões de quilates ( $1 \mathrm{ct}=0,2 \mathrm{~g}$ ), ou seja, 25 toneladas métricas (Haggerty 1999). A produção de diamante sintético também vem crescendo significativamente sendo superior ao montante da produção natural. O desenvolvimento da síntese de filmes finos (Fritzen 1997), pelo processo CVD carbon vapour deposit ocorrido nos últimos anos deverá ampliar e diversificar ainda mais o emprego do diamante na indústria.

\subsection{Diamante no Estado de Mato Grosso}

A procura de bens minerais no Estado do Mato Grosso teve início com a chegada dos primeiros Bandeirantes, ávidos por encontrar ouro e pedras preciosas (Abreu 1975). Assim sendo, por volta de 1647, o ouro foi descoberto em Araés, no Vale do Rio das Mortes, mas o povoamento só começou em 1718, quando foi encontrado ouro no Rio Cuiabá, levando os colonizadores a se estabelecerem na região. A cidade de Cuiabá foi fundada oficialmente em 1727 e, em 1748, foi criada a Capitania de Cuiabá e Mato Grosso, desde então abreviada para Mato Grosso (Baxter 1988).

Pouco depois das descobertas iniciais de diamantes na região de Diamantina, Minas Gerais, durante a segunda década do século XVIII (Abreu 1973), foram encontradas as primeiras ocorrências diamantíferas do Estado de Mato Grosso, nas nascentes do Rio Paraguai (Castelnau 1949). Estes depósitos eram exclusividade da Coroa Portuguesa e por este motivo a exploração dos garimpos só começou a partir de 1805, quando a Coroa autorizou a exploração, reservando porém, o privilégio da compra das gemas.

As atividades mineradoras da Bacia do Alto Rio Paraguai iniciaram-se com a 
produção de ouro, que aumentou rapidamente levando à formação de núcleos urbanos e conseqüentemente, à criação do Arraial do Alto Paraguai, hoje Município de Diamantino (Figura 1.1). Posteriormente, com a descoberta do diamante ocorreu a intervenção da administração da Capitania e, de 1746 em diante, várias lavras foram sendo descobertas e fechadas pela Coroa, entre elas as famosas Minas dos Francisquinhos. Segundo Silva et al. (1997), um novo ciclo do diamante ocorreu por volta de 1930, através das descobertas do Rio Pari e mais tarde do Córrego do Gatinho, que deu origem ao povoado do Gatinho e mais tarde à cidade de Alto Paraguai.

Segundo Abreu (1975), a exploração do diamante sofreu um incremento na primeira década do século XIX na parte norte do Estado, declinando com o apogeu das plantações de seringueira, para ressurgir no centro e sudeste no princípio deste século e, posteriormente, adquirir grande destaque nos anos trinta.

Por volta de 1909, o diamante foi descoberto em vários afluentes do Rio das Garças, cuja exploração foi intensificada até 1924. Nesse mesmo ano João Arenas Teixeira descobriu diamantes em vários tributários do Rio das Pombas e, em 1926 no vale do Rio Poxoréu (Baxter 1988). A exploração aumentou rapidamente ao longo do Rio Poxoréu e de seus tributários menores, resultando no estabelecimento de um novo núcleo urbano que evoluiu para a atual Cidade de Poxoréu (Figura 1.1). Segundo este autor, os primeiros anos do século $X X$ constituiram um período de intensa atividade mineradora no Estado de Mato Grosso. Entre as principais regiões garimpadas, destacaram-se aquelas situadas nas cabeceiras do Rio Paraguai, Coxim e Jauru, bem como as áreas situadas nos vales dos Rios das Mortes, das Garças e Araguaia desde sua fonte até a ilha do Bananal.

A região de Chapada dos Guimarães (Figura 1.1), foi garimpada por escravos em busca de ouro no século passado, mas somente em 1933 o primeiro garimpo de diamante se desenvolveu no Córrego da Água Fria. A partir deste, outros garimpos foram sendo descobertos, entre eles o garimpo da Passagem do Mamão e do Peba. A produção perdurou até 1960, quando entrou em declínio devido à exaustão, depredação e entulhamento das áreas de fácil extração (Weska 1987).

Em Paranatinga (Figura 1.1), a garimpagem do diamante teve inicio em meados de 1951 nos leitos, terraços aluvionares e nos cascalhos que jazem ao longo das drenagens dos Rios Batovi e Jatobá (Oliva 1974, In: Barros et al. 1982).

A exploração do diamante em Mato Grosso divide-se em três zonas: a) centro- 


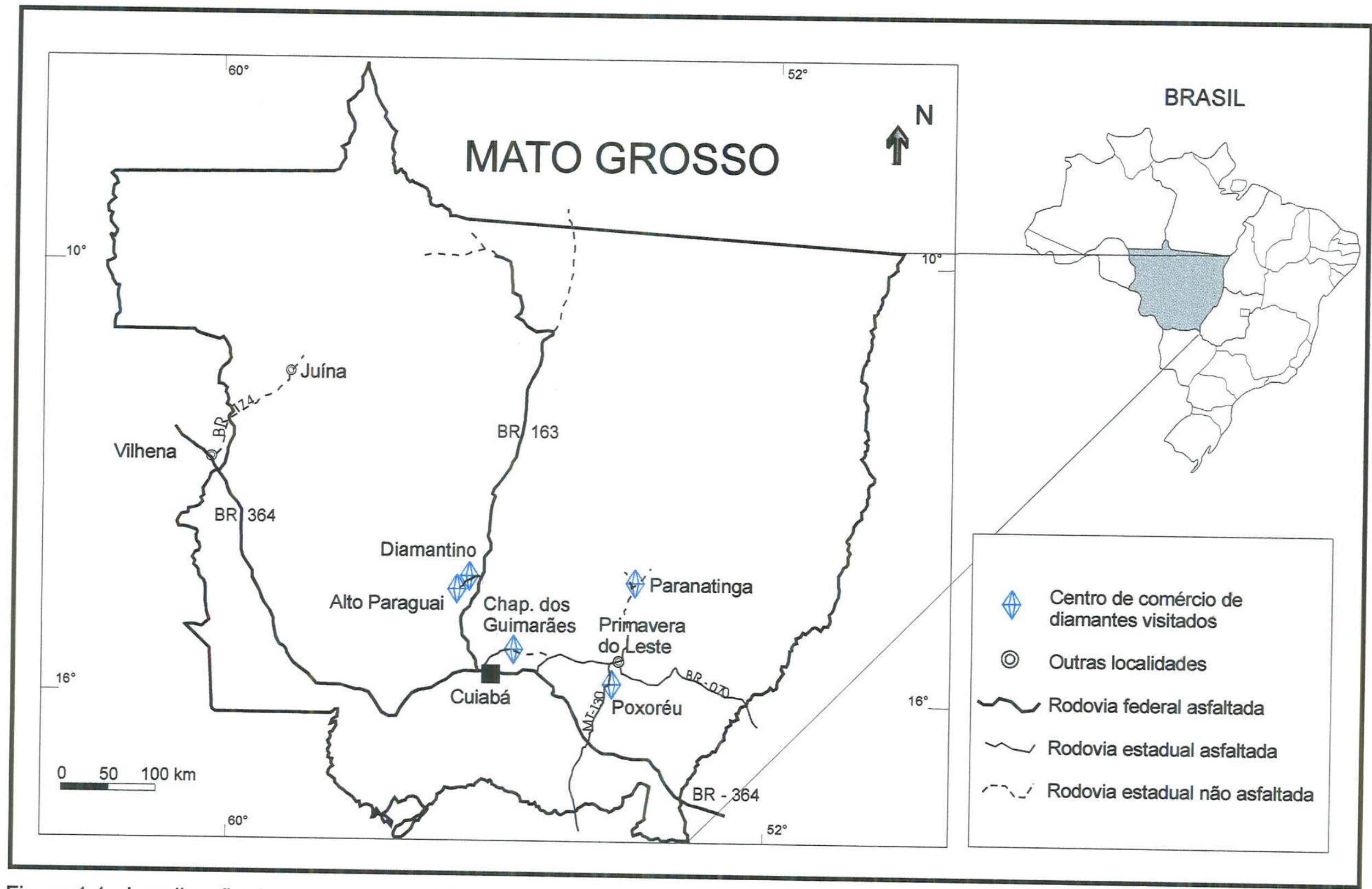

Figura 1.1 - Localização dos centros geográficos do comércio de diamante amostrados no decorrer deste trabalho. 
norte, compreendendo o Alto Paraguai e seus afluentes Sepotuba, Brumado, Cabaçale Jauru, bem como as cabeceiras do Arinos que verte para a Bacia Amazônica; b) centro-sul, incluindo rios do centro do estado tais como Taquari, Coxim, Jauru e Aquidauana e c) centro-leste, compreendendo os Municipios de Barra do Garças, Tesouro, Guiratinga, Torixoréu, Ponte Branca, Alto Garças e Alto Araguaia (Abreu 1975).

Existem garimpos em praticamente todas as bacias hidrográficas do estado (Weska 1996), destacando-se aquelas situadas na região noroeste (Juína e Aripuanã), porções centrais como as cabeceiras dos Rios Paraguai (Arenápolis e Diamantino), Cuiabá (Chapada dos Guimarães), Vermelho (Poxoréu e Dom Aquino) e dos Rios Teles Pires e Xingu (Paranatinga). As porções extremo sudeste (Itiquira) e extremo leste do Estado (região de cabeceiras do Alto Araguaia), destacam-se como as mais antigas produtoras de diamante aluvionar (Figura 1.2).

Observa-se pelo exposto, que a garimpagem do diamante nas diversas regiões de Mato Grosso vem flutuando desde as descobertas originais. Inicialmente, a intervenção da Coroa Portuguesa inibiu a produção e descobertas novas. Essa situação perdurou até 1805 quando a Coroa finalmente liberou as áreas de garimpagem. Nas últimas décadas do século dezenove, a expansão das plantações de seringueira (árvore da qual se extrai a borracha) criou um novo elemento econômico diminuindo o interesse pelo garimpo e, conseqüentemente, provocando a queda da produção.

Um dos últimos grandes impulsos na produção de diamante ocorreu por volta de 1924, com a descoberta dos garimpos da região de Poxoréu, cujo apogeu aconteceu no decorrer dos anos trinta, estando bastante reduzido nos dias atuais. O último e mais importante pico de produção ocorreu na região de Juína durante os anos oitenta. Além da grande quantidade de diamante industrial produzida, a região tornou-se famosa pela ocorrência de megadiamantes, isto é, pedras com pesos acima de 50 quilates (Svisero 1995).

Em decorrência de fatores econômicos e administrativos, as reservas de diamante do Estado foram mal prospectadas. Por este motivo, apesar da importância econômica que representaram e ainda representam, as regiōes envolvidas pouco se beneficiaram e provavelmente pouco se beneficiarão até ocorrer a estagnação deste bem mineral, tendo ainda como prejuízo a degradação do meio ambiente e a resultante deterioração dos núcleos populacionais garimpeiros. 


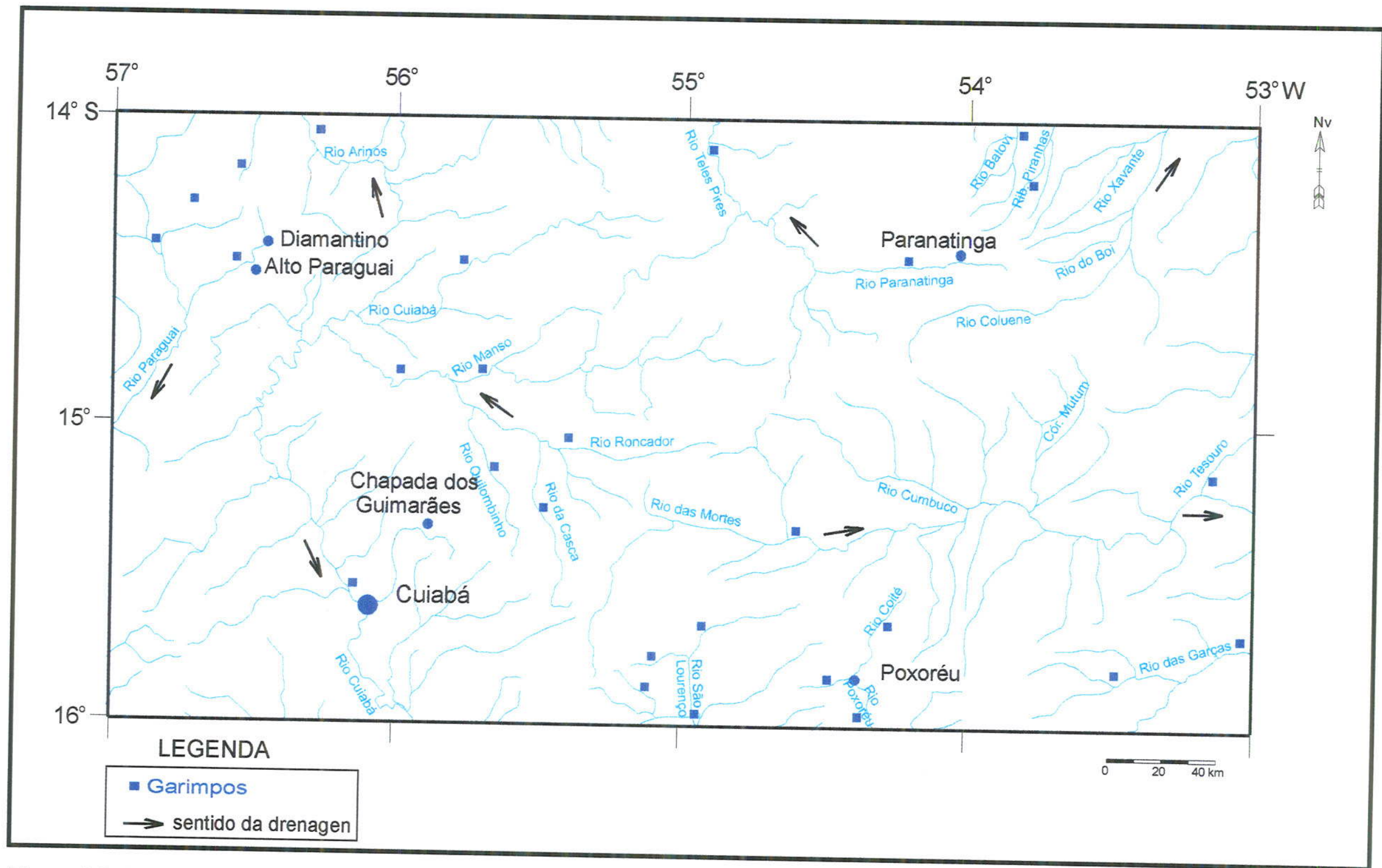

Figura 1.2 - Mapa hidrográfico da região estudada mostrando a distribuição dos principais garimpos de diamante existentes na região. Modificado de Radambrasil (1982), Mapa hidrográfico, Folha SD-21, Escala 1: 1000000. 


\subsection{Localização geográfica das áreas}

A região de Poxoréu está situada aproximadamente a $200 \mathrm{~km}$ a leste de Cuiabá, capital do Estado de Mato Grosso (Figura 1.1). O acesso, partindo de Cuiabá em direção a Rondonópolis, é feito através da BR-364 na qual percorre-se $87 \mathrm{~km}$. A partir desse ponto, toma-se à esquerda a rodovia BR-070 em direção à cidade de Campo Verde e Primavera do Leste. Após $86 \mathrm{~km}$ de percurso nesta rodovia, existe um entroncamento no qual entra-se à direita na MT-130 e, após $30 \mathrm{~km}$ chega-se à cidade de Poxoréu (Figura 1.1).

O Município de Paranatinga localiza-se na porção centro-leste de Mato Grosso a $300 \mathrm{~km}$ de Cuiabá. O acesso à Paranatinga é o mesmo de Poxoréu até o entroncamento com a MT-130. A partir deste entroncamento, percorre-se mais $10 \mathrm{~km}$ na BR-070 até Primavera do Leste. Paranatinga localiza-se a $85 \mathrm{~km}$ desta cidade a qual pode ser alcançada por uma estrada não pavimentada (Figura 1.1).

A região de Chapada dos Guimarães localiza-se a nordeste de Cuiabá, a aproximadamente $74 \mathrm{~km}$, sendo que o acesso à esta região é feito pela rodovia estadual MT-305 (Figura 1.1).

Diamantino localiza-se a norte de Cuiabá, da qual dista $162 \mathrm{~km}$. Partindo de Cuiabá, percorre-se $153 \mathrm{~km}$ pela BR-163 até o entroncamento com a rodovia estadual que da acesso à cidade de Diamantino, após um percurso de $9 \mathrm{~km}$. Quanto à cidade de Alto Paraguai, esta localiza-se a $177 \mathrm{~km}$ de Cuiabá. O acesso à esta região é o mesmo até Diamantino, de onde segue-se por uma rodovia estadual mais $15 \mathrm{~km}$ até o município de Alto Paraguai (Figura 1.1).

As rodovias asfaltadas e as estradas de terra mencionadas possuem boas condições de trafego durante a estação seca do ano que se estende de abril a outubro. Durante a estação chuvosa, entre os meses de novembro a março, o tráfego nas estradas de terra torna-se difícil.

\subsection{Aspectos fisiográficos}

As regiões abrangidas neste trabalho apresentam similaridade em algumas características fisiográficas por se localizarem relativamente próximas uma das outras. Conseqüentemente, apresentam índices pluviométricos e tipos de vegetação 
semelhantes. No entanto, diferem nos padrões de drenagem e de relevo.

\subsubsection{Clima}

No tocante às características climáticas, as regiōes de Poxoréu, Chapada dos Guimarães e Paranatinga são marcadas por duas estações bem definidas; uma seca entre os meses de abril e outubro e outra chuvosa entre os meses de novembro $e$ março. A média de precipitação pluviométrica anual passa de $1600 \mathrm{~mm}$, com chuvas mais freqüentes no mês de dezembro. A temperatura média nestas localidades é de $30^{\circ} \mathrm{C}$, sendo que as médias máximas ocorrem nos meses de setembro a dezembro e as médias mínimas de julho a agosto.

Nas regiões de Diamantino e Alto Paraguai as características climáticas são marcadas também por duas estações; uma seca entre os meses de maio a setembro e outra chuvosa entre os meses de outubro a abril. A média de precipitação pluviométrica anual é de $1750 \mathrm{~mm}$, com intensidade máxima de janeiro a março. A temperatura média nestas localidades é de $24^{\circ} \mathrm{C}$; as médias máximas ocorrem nos meses de setembro a dezembro e as médias mínimas de julho a agosto.

\subsubsection{Vegetação}

A vegetação é caracterizada por cerrados, matas tropicais, matas ciliares e por pastagens que são derivadas da atividade agropecuária intensa, tanto em Poxoréu $e$ Chapada dos Guimarães como em Paranatinga. A vegetação, segundo Baxter (1988), reflete as unidades litológicas. Segundo Weska (1996a), em solos pobres arenosos derivados de unidades litológicas areníticas predomina vegetação do tipo cerrado, enquanto nos solos ricos originados da alteração de rochas básicas a ultrabásicas, concentram-se matas do tipo tropical ou parte de matas ciliares.

A vegetação é diversificada e condicionada à litologia tanto na região de Alto Paraguai como em Diamantino. Segundo Barros et al. (1982), nessas áreas predominam os cerrados, as savanas abertas, as matas tropicais, as matas do tipo galeria ou ciliares e as pastagens. 


\subsubsection{Drenagem}

As regiöes de Chapada dos Guimarães, Poxoréu e Paranatinga, representam o divisor das bacias do Prata ao sul e Amazonas ao norte (Barros et al. 1982). Na região de Poxoréu, as drenagens da bacia do Rio Vermelho abastecem a bacia do Prata; a bacia do Tocantins, por sua vez é abastecida pelos tributários do Rio das Mortes. $O$ padrão de drenagem dessas regiões é representado pelos tipos retilíneo, retangular e subretangular, possuindo condicionamento estrutural evidenciado por alinhamentos NW e NE, e secundariamente EW e NS (Figura 1.2).

As drenagens que ocorrem em Diamantino e Alto Paraguai, compreendem o alto curso do Rio Paraguai e seus afluentes, os quais apresentam um padrão de drenagem paralelo de primeira ordem (Figura 1.2). Ao norte dessas localidades as drenagens demostram forte influência estrutural, mantendo a direção geral NE-SW, sendo os cursos ligeiramente paralelos entre si (Barros et al. 1982). A rede básica de drenagem nestas localidades é formada pelo Rio Paraguai a sudoeste, Rio Arinos a norte e Rio Cuiabá a sul.

A Figura 1.2 mostra também a distribuição geográfica dos principais garimpos existentes na região balizada pelos municípios de Diamantino, Paranatinga, Poxoréu e Cuiabá, incluindo-se serviços em andamento e frentes desativadas. Do ponto de vista geológico, a garimpagem é realizada em diversos tipos de depósitos abrangendo cascalheiras de leito ativo, terraços, aluviões recentes e em menor intensidade coluvios modernos.

\subsubsection{Relevo}

Poxoréu e Chapada dos Guimarães localizam-se no Planalto dos Guimarães (Figura 1.3). Weska (1996a) define o relevo destas regiões como diversificado, sendo as principais formas em ordem de importância representadas por chapadões (planaltos), escarpas, terraços e planícies aluviais, superfícies residuais, morros testemunhos, tálus, altos topográficos e blocos basculados.

A região de Paranatinga, caracterizada pelo relevo rebaixado e pelas formas tabulares, localiza-se na Depressão Interplanáltica de Paranatinga, estando posicionada entre a Província Serrana e os Planaltos dos Parecis e Guimarães (Figura 


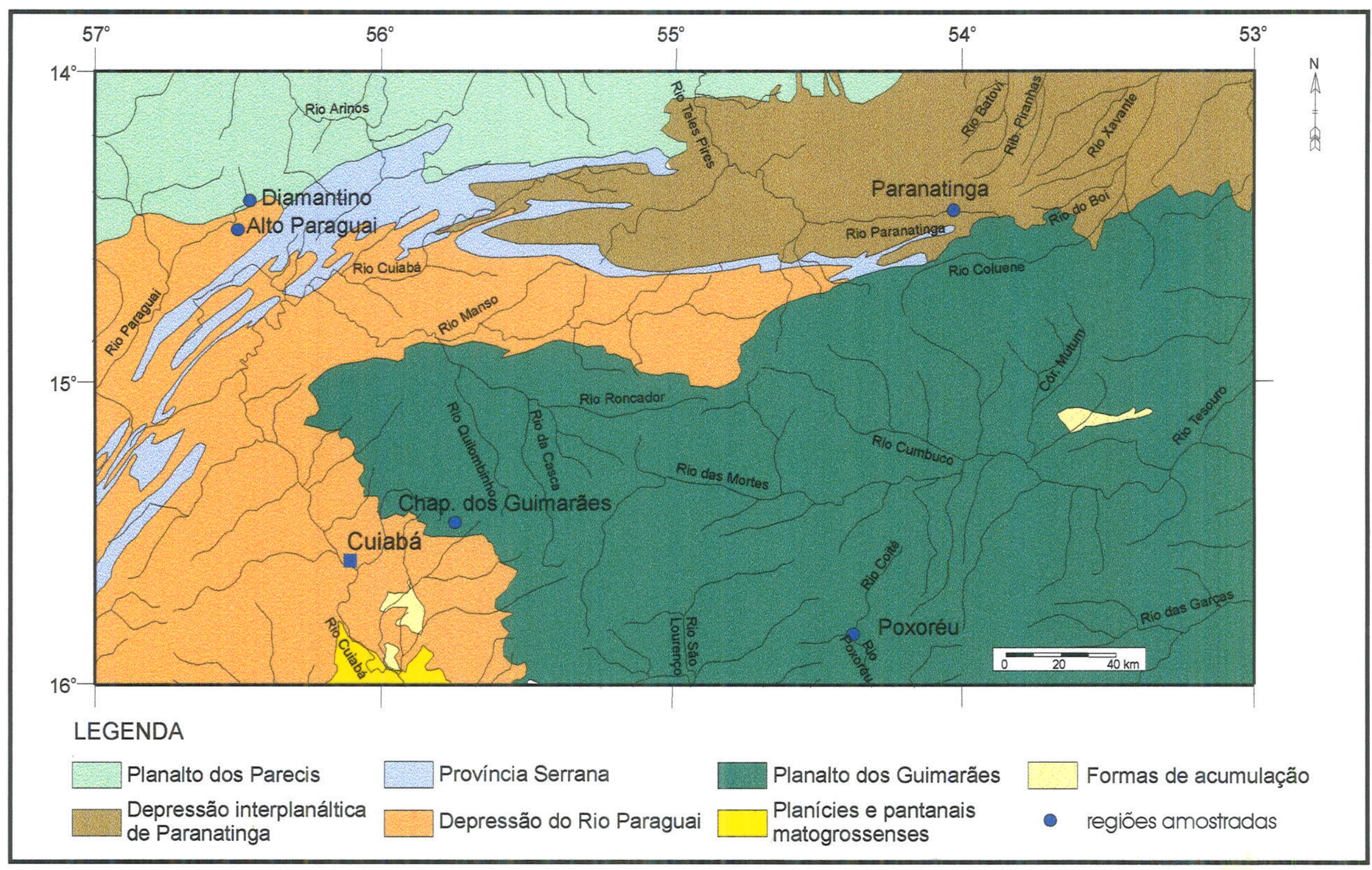

Figura 1.3 - Mapa geomorfológico da região balizada pelos municípios de Poxoréu, Chapada dos Guimarães, Paranatinga, Diamantino e Alto Paraguai. Extraido de Radambrasil (1982), Mapa geomorfológico, Folha SD-21, escala 1:1.000.000. 
1.3).

Diamantino e Alto Paraguai localizam-se em uma região denominada Depressão do Alto Paraguai, demarcada a norte pela Serra de Tapirapuã, a leste pela Província Serrana e a nordeste pelo Planalto dos Parecis (Figura 1.3). A Depressão do Alto Paraguai corresponde à uma superfície de relevo pouco dissecado, com pequeno caimento topográfico de norte para o sul. Na região onde está localizada a cidade de Diamantino, observa-se a presença de um relevo fortemente escarpado constituindo uma crista assimétrica. Já em Alto Paraguai observa-se o predomínio das planícies e terraços (Barros et al. 1982).

A Província Serrana é uma região de relevo dobrado caracterizado por uma sucessão de anticlinais e sinclinais alongados, estando posicionada entre a borda sul da Plataforma do Guaporé e a extremidade nordeste da Bacia do Paraná. O conjunto apresenta duas direções estruturais dominantes, sendo uma NE-SW e outra E.W. O prolongamento leste do conjunto serrano se estende até próximo da localidade de Paranatinga (Figura 1.3).

O Planalto dos Parecis compreende um extenso conjunto de relevo sendo caracterizado por duas feições distintas: a Chapada dos Parecis e o Planalto dissecado dos Parecis. Este último é mais representativo nas regiões de Alto Paraguai e Diamantino, sendo a sua principal característica a relativa homogeneidade com predominância de formas tabulares (Figura 1.3).

\subsection{Objetivos}

$\mathrm{Na}$ literatura geológica do Estado de Mato Grosso, os trabalhos disponíveis sobre as ocorrências diamantíferas, abordam de modo geral aspectos da geologia regional, estratigrafia, tectônica e petrogênese (Batista 1991; Weska 1996a; Filemon et al. 1997; Gibson et al. 1997; Greenwood et al. 1998). Contudo, descrições detalhadas e dados estatísticos sobre as características mineralógicas e gemológicas de diamantes são praticamente inexistentes.

Nessas condições, o objetivo principal do trabalho foi realizar estudos pormenorizados sobre as características mineralógicas de diamantes detríticos das regiões de Chapada dos Guimarães, Poxoréu, Diamantino, Paranatinga e Alto Paraguai localizadas na porção centro-sul do estado. Durante esse estudo, os 
diamantes foram classificados segundo a granulometria e o peso, morfologia cristalina, microestruturas de superfície, cor macroscópica, fluorescência ao ultravioleta, inclusões minerais e relação gema/indústria. Os estudos desenvolvidos apoiaram-se nos critérios adotados anteriormente por Leite (1969), Svisero (1971) Svisero et al. (1981), Harris et al. $(1975,1979)$, entre outros, com a finalidade de viabilizar a correlação com diamantes de outras localidades estudados por Whitelock (1973), McCallum et al. (1979), Chieregati (1989), McCallum et al. (1994), Otter et al. (1994), Trautman et al. (1997), Chaves (1997), entre outros. Desta forma uma vez levantados e tratados os dados mineralógicos do diamante das regiōes acima mencionadas, os mesmos foram comparados com outras áreas incluindo-se aqui, principalmente, depósitos secundários do Brasil e fontes primárias da África do Sul, Estados Unidos da América, Austrália, Canadá e Rússia. 


\section{MATERIAIS E MÉTODOS}

A realização desta dissertação envolveu atividades de campo e de laboratório, voltadas para a caracterização mineralógica e gemológica de diamantes de várias regiões garimpeiras do Estado de Mato Grosso, a qual exigiu a realização de uma série de atividades diferentes daquelas empregadas em estudos mineralógicos e petrológicos convencionais. Foi considerado conveniente sistematizar neste capítulo, ainda que de forma condensada, as principais etapas e métodos utilizados no decorrer da pesquisa.

O trabalho teve início com uma ampla pesquisa bibliográfica sobre a literatura nacional e internacional referente ao diamante, ocasião em que foram destacadas as publicações sobre a distribuição e os diversos tipos de classificação desse mineral Entre as publicações consultadas mereceram atenção especial àquelas referentes ao Triângulo Mineiro (Leite 1969), Romaria, Minas Gerais (Svisero et al. 1981; Svisero \& Haralyi 1985), Tibagi, Paraná (Chieregati 1989) e Serra do Espinhaço, Minas Gerais (Chaves et al. 1993; Chaves 1997) e, ainda de outros países tais como Lesotho (Whitelock 1973), África do Sul (Harris et al. 1975, 1979), Estados Unidos (McCallum et al. 1979, 1994; Otter et al. 1994), Austrália (Hall \& Smith 1984; Trautman et al. 1997), Canadá (Davies et al. 1998) entre outros. A maioria dos trabalhos utilizados foram encontrados no acervo da biblioteca do Instituto de Geociências da Universidade de São Paulo (IG/USP).

Após o levantamento bibliográfico, foram iniciadas as atividades de campo, que resultaram na coleta de dados sobre a morfologia, a cor, a granulometria e outras propriedades do diamante, da região centro sul de Mato Grosso. A maior parte dos dados referentes aos diamantes foram obtidos nos centros de comércio situados em Poxoréu, Paranatinga e Cuiabá e, sobre eles serão dadas informações adicionais nos itens subseqüentes. Complementando os trabalhos de campo foram confeccionados, através do programa CorelDraw 7.0, os mapas de localização geográfica, de drenagens, o geomorfológico e o geológico das áreas estudadas. As amostras adquiridas foram posteriormente tratadas em laboratório e os resultados obtidos serão discutidos nos capítulos subseqüentes. 


\subsection{Trabalhos de campo}

Como foi mostrado no capítulo introdutório, Mato Grosso é talvez o estado brasileiro mais rico em ocorrências e depósitos diamantíferos, sendo há vários anos o maior produtor nacional dessa gema. Entre as diversas ocorrências conhecidas, foram escolhidas aquelas das regiões de Poxoréu, Chapada dos Guimarães, Paranatinga, Diamantino e Alto Paraguai, situadas na porção centro sul do Estado. Vários foram os motivos que determinaram a escolha dessas áreas. Poxoréu, por exemplo, constituiu no decorrer dos anos trinta um dos principais pólos produtores do País. Além disso, a região vem sendo estudada com grandes pormenores nos últimos anos no tocante à geologia regional, estratigrafia e tectônica. Weska (1996a) efetuou uma síntese destas questões posicionando os depósitos diamantíferos no arcabouço estratigráfico regional. Entretanto o referido autor não desenvolveu estudos desses diamantes. Dispondo dessa base geológica integrada foi considerado conveniente completar o trabalho de Weska (op cit.) caracterizando o diamante dessa região. Paranatinga constitui uma área interessante por conter um campo de kimberlitos nas adjacências, no qual Fragomeni (1976) reportou a presença de quase 50 intrusões. Um desses corpos denominado Batovi 1 foi estudado por Svisero \& Meyer (1986), que mostraram tratar-se de um kimberlito do Grupo I (basáltico). Diamantino, Alto Paraguai e Chapada dos Guimarães constituem garimpos antigos, possuindo portanto interesse histórico. Além disso, essas áreas continuam produzindo diamantes até os dias atuais.

Definida a filosofia de trabalho, foram realizados contatos com fornecedores de diamante nas regiões de estudo, os quais uma vez conscientizados dos objetivos do trabalho, concordaram em colocar à disposição os lotes para exame. Isso feito, foram realizadas três campanhas de campo no decorrer das quais foram coletados os dados que compõem essa Dissertação.

A obtenção de informações sobre os diamantes em cada das áreas mencionadas, envolveu uma série de dificuldades tendo em vista que os garimpeiros geralmente não possuem lotes grandes. Por estes motivos, recorremos aos fornecedores locais, os quais compram e armazenam a produção individual dos garimpeiros, formando desse modo lotes representativos.

Nesse sentido, após contatos efetuados previamente, foram realizadas três etapas de coleta de dados nos respectivos locais, onde, utilizando peneira, balança, 
lupa de mão (10x), lupa binocular e lâmpada de luz ultravioleta, foram obtidos dados mineralógicos dos diamantes para tratamentos posteriores.

Durante o exame dos lotes de diamantes, foram obtidos dados referentes à granulometria, morfologia, cor, fluorescência e outras propriedades físicas do diamante. Esse foi o único procedimento viável, pois de outra forma, seria impraticável a observação direta nos garimpos, uma vez que a produção individual dos garimpeiros é pequena, sendo necessário permanecer nas frentes de trabalho de cada área amostrada para coletar os dados. Houve também, entendimento prévio com os compradores para garantir a exatidão da procedência dos diamantes das áreas estudadas.

Além dos lotes dos fornecedores locais, foram adquiridos também, alguns lotes de cristais contendo particularidades mineralógicas tais como hábitos cristalinos, geminações, inclusões minerais, microestruturas, entre outras. Os cristais escolhidos como representativos para estudos laboratoriais foram analisados nos laboratórios de Óptica e Microscopia Eletrônica de Varredura do GSA/IG/USP. Os procedimentos desenvolvidos nestes laboratórios não foram destrutivos, preservando-se desta forma as amostras para trabalhos posteriores.

\subsubsection{Registro dos dados obtidos}

Os dados extraídos dos lotes examinados foram arquivados em fichas individuais elaboradas especialmente para esse tipo de atividade, nas quais estão condensadas todas as informações possíveis para cada diamante. Essa prática tornou possível a correlação entre propriedades distintas, deixando em aberto a possibilidade de outras correlações em trabalhos futuros.

A Tabela 2.1 mostra o modelo de uma ficha utilizada na coleta dos dados mineralógicos de cristais individuais. Ela tem a vantagem de poder ser complementada, retrabalhada e modificada no decorrer da pesquisa, funcionando também como um arquivo permanente. Nela estão previstas praticamente todas as propriedades físicas do diamante, mesmo aquelas que não puderam ser trabalhadas no decorrer dessa Dissertação, tais como o comportamento no infravermelho (IV), composição isotópica em termos de $\delta^{13} \mathrm{C}$ e $\delta^{15} \mathrm{~N}$ e a catodoluminescência. Considerando as características do Mestrado - trabalho formativo com tempo limitado -, optou-se por dar ênfase às 
Tabela 2.1 - Caracterização individual dos cristais de diamante.

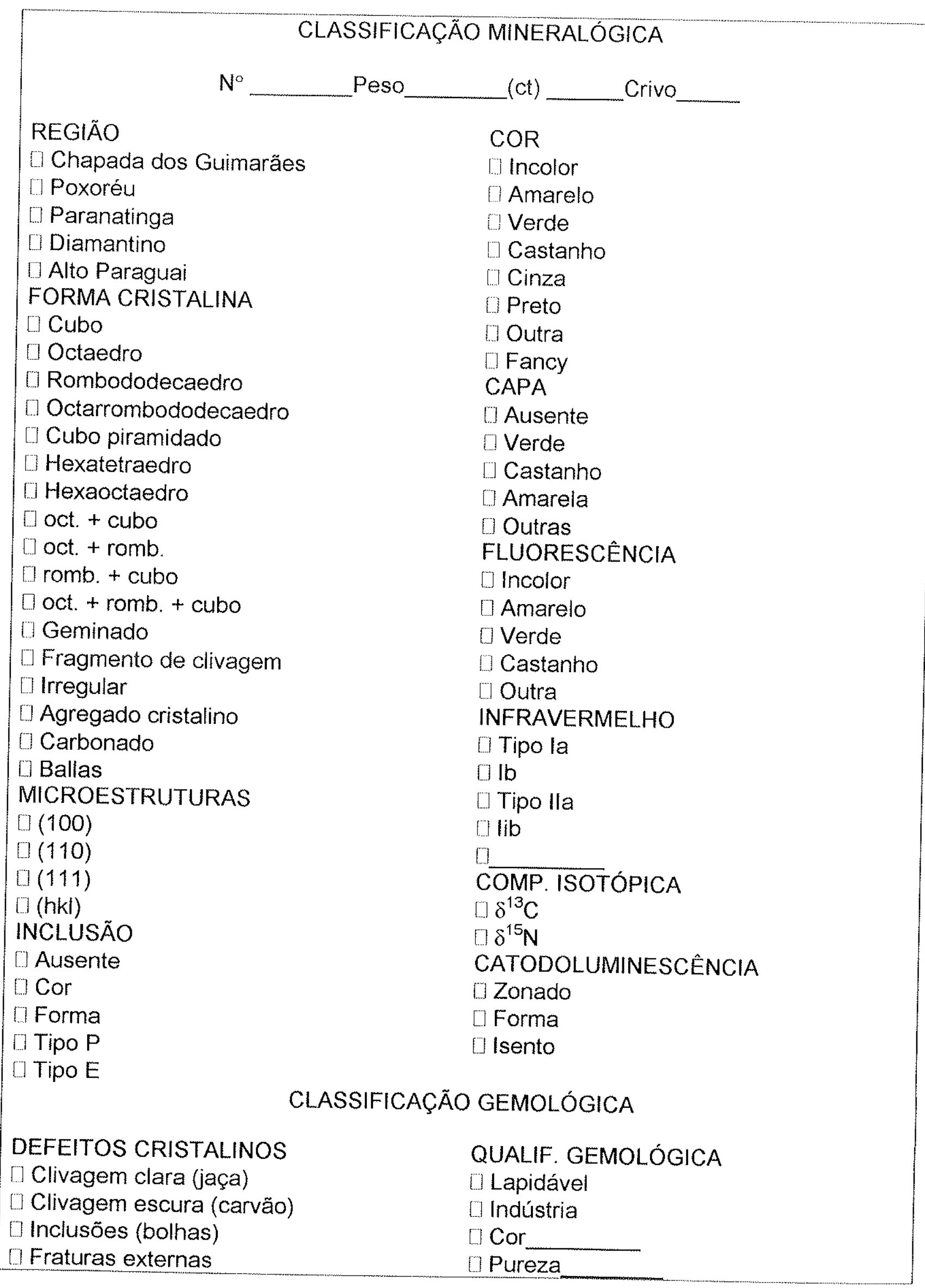


Tabela 2.2 - Caracterização dos lotes de diamantes estudados no decorrer desse trabalho. A disposição das variáveis usadas foi escolhida com o intuito de facilitar correlações entre as diversas propriedades morfológicas e físicas dos cristais. Obs: inc=incolor, ama= amarelo, ver $=$ verde, cas $=$ castanho, $\operatorname{cin}=\operatorname{cinza}$, $p r e=$ preto, out $=$ outros e fan $=$ fantasia.

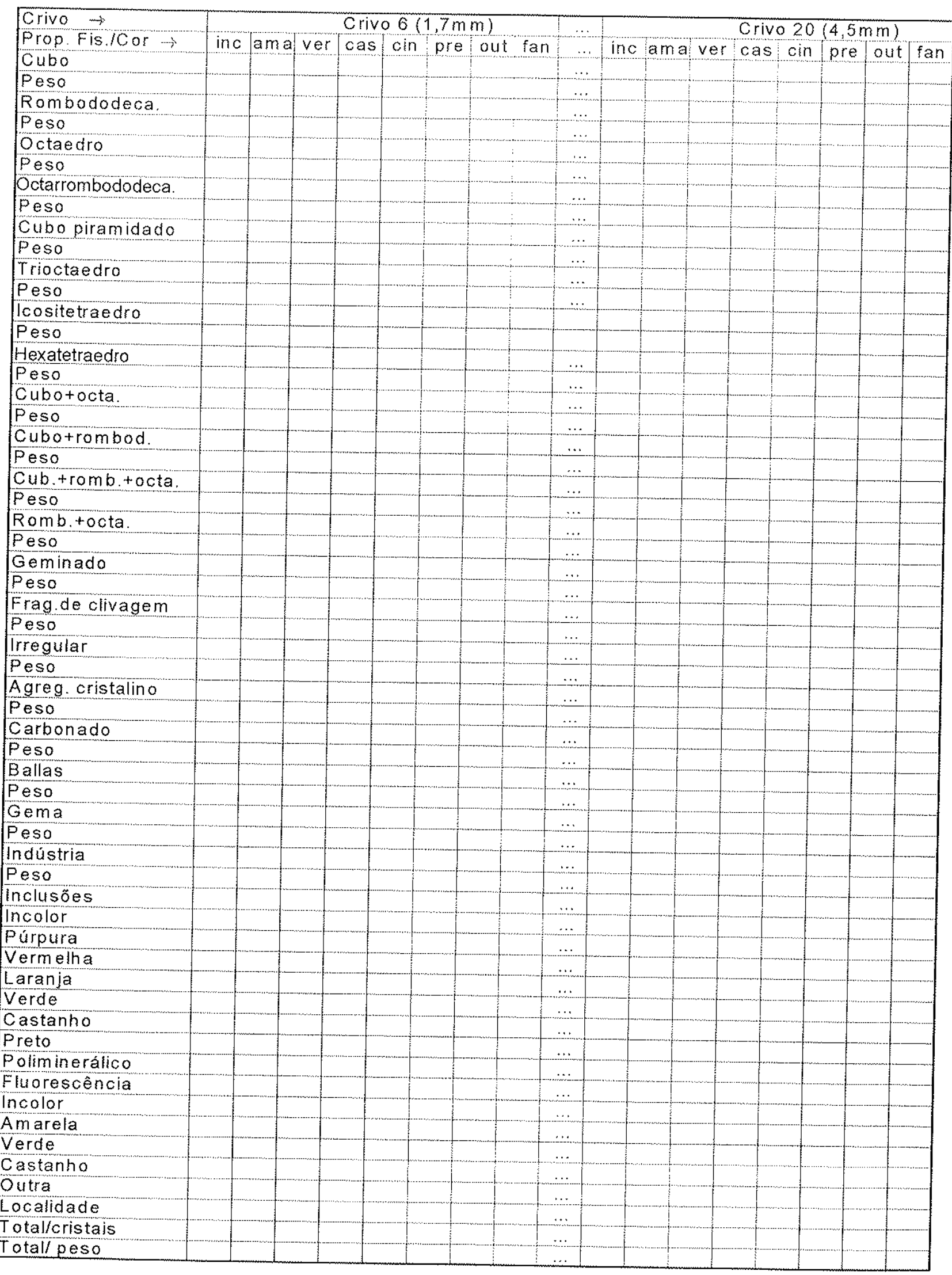


propriedades clássicas da pesquisa mineralógica, ou seja, morfologia cristalina fundamentada na cristalografia geométrica, bem como o estudo das propriedades físicas básicas tais como granulometria, cor macroscópica, inclusões minerais e comportamento luminescente. O comportamento no infravermelho bem como as características isotópicas constituem temas que poderão ser desenvolvidos posteriormente.

A Tabela 2.2 mostra outro tipo de ficha, elaborada no decorrer desse trabalho, que se mostrou mais útil no exame de lotes constituídos por um grande número de espécimes. Como se pode observar pelo modelo apresentado, as propriedades principais (hábito, cor, granulometria, etc.) estão dispostas de tal forma que podem ser relacionadas entre si a qualquer momento facilitando as interpretações dos resultados.

A partir dos dados obtidos foram efetuados vários tipos de classificações de natureza acadêmica, que permitiram correlacionar as áreas estudadas entre si, e também entre distritos diamantíferos de outros países. Finalmente, os dados obtidos foram correlacionados com classificações gemológicas utilizadas no comércio internacional do diamante, tornando-se evidente que os critérios utilizados nas classificações gemológicas na realidade estão baseados nas características físicas do diamante.

\subsection{Trabalhos de laboratório}

A descrição de alguns procedimentos adotados durante as fases laboratoriais podem ser encontradas em dissertações de mestrado e teses apresentadas no IG/USP. Para o entendimento dos trabalhos realizados, apresentaremos a seguir um resumo dos métodos usados durante a fase de obtenção dos dados.

\subsubsection{Preparação das amostras}

Os diamantes previamente adquiridos foram lavados em uma solução de $\mathrm{HCl}$ 1:1 para a remoção de impurezas tais como hidróxidos e argilas retidos nos interstícios do micro relevo dos cristais. Posteriormente, foram lavados com HF concentrado para a remoção de grãos de sílica, óxidos e outras impurezas presentes no relevo. Após a limpeza os cristais foram classificados individualmente quanto à morfologia, cor, tipo de 
inclusões, presença ou não de estruturas de superfície, defeitos estruturais ou qualquer outra característica apresentada que fosse relevante. Estes estudos foram realizados no laboratório de óptica do Departamento de Mineralogia e Geotectônica do Instituto de Geociências da Universidade de São Paulo (GMG/IG/USP), utilizando-se uma lupa binocular de marca Olympus. Concluídas essas observações, os exemplares foram guardados separadamente em envelopes numerados, facilitando dessa forma o manuseio e o uso em testes posteriores.

\subsubsection{Microscopia óptica}

Os métodos ópticos foram utilizados de forma intensiva em todas as fases desta pesquisa. Durante os trabalhos de campo utilizamos simultaneamente uma lupa de mão com aumento de 10x e uma lupa binocular Olympus com aumentos variáveis de até $40 x$, para a obtenção dos dados relativos à morfologia, à cor, estruturas de superfície, tipo e número de inclusões e outras particularidades mineralógicas.

Durante os trabalhos desenvolvidos nos laboratórios do GMG/IG/USP, foi utilizada uma lupa binocular Olympus SZH 10, a qual possui uma máquina fotográfica acoplada, marca Canon, dispositivo de aumento progressivo (zoom) de até 200 vezes e com sistema de luz transmitida e luz incidente. Nesta fase foram obtidos dados sobre as formas cristalográficas presentes nos cristais, os hábitos cristalinos e os tipos de geminados.

Durante os exames realizados com os diamantes no microscópio petrográfico, foi necessário inicialmente contornar o problema da reflexão total provocada pelo alto valor do índice de refração do diamante $(n=2,42)$. O problema foi resolvido examinando-se as amostras em um recipiente contendo Nujol, de índice de refração $n=1,45$, que atenua ou mesmo elimina as reflexões produzidas nas bordas dos cristais. Esse procedimento favoreceu as observações no interior dos diamantes durante o exame das inclusões minerais e dos defeitos cristalinos em geral.

Os cristais contendo inclusões cristalinas foram observados sob diversos aumentos no fotomicroscópio Zeiss Axioplan com sistema progressivo de aumento (zoom) de até 930 vezes, existente do GMG/IG/USP. Este fotomicroscópio dispõe de luz transmitida e refletida com filtros que permitem diminuir ou aumentar a intensidade de luz. A variação na intensidade da luz transmitida e incidente permite que se obtenha 
os melhores efeitos de luz, nitidez, cor e britho na obtenção de fotografias dos cristais e de suas inclusões.

Também foi possível estudar com mais detalhes certas características internas que são melhor observadas sob luz polarizada, tais como feições de crescimento, disposição das inclusões identificando as várias formas, cores e dimensões. Foram analisados também empilhamento dos planos de crescimento cristalino, variações no desenvolvimento das faces e microestruturas nas superfícies planas e abauladas.

\subsubsection{Microscopia eletrônica de varredura}

No decorrer dos trabalhos foi utilizado o Microscópio Eletrônico de Varredura, modelo LEO 440i, pertencente ao Departamento de Geologia Sedimentar e Aplicada (GSA/IG/USP), para análise da morfologia e das microestruturas de superfície presentes no relevo dos cristais de diamante.

O princípio do método do equipamento baseia-se na incidência de um feixe eletrônico fino com características pré-definidas, produzido por um filamento de tungstênio que varre a superfície da amostra previamente metalizada, permitindo aumentos acima de 100 mil vezes e, gerando imagens tridimensionais sempre em foco.

Ao incidir sobre a amostra, os elétrons do feixe penetram e colidem com os elétrons do átomo, produzindo elétrons retroespalhados e secundários. No primeiro caso, os elétrons do feixe ao colidirem com os elétrons do átomo sofrem desvio de direção e vão para a superfície, conservando em média $80 \%$ de sua energia original. No caso dos elétrons secundários, o elétron incidente penetra próximo ao núcleo de um átomo no espécime e desloca um elétron do seu orbital, tornando-o ionizado e excitado. Os elétrons secundários geralmente possuem energia de apenas alguns elétron-volts (Goldstein et al. 1994).

Durante a formação do elétron secundário, a vaga na camada do elétron ejetado é preenchida por um elétron de uma camada mais externa, que deve liberar uma quantidade de energia igual a diferença entre os niveis de energia das duas camadas, emitindo raios $X$. Os sinais emitidos pelos elétrons são detectados, ampliados e enviados à tela de um tubo de raios catódicos mostrando uma imagem da amostra varrida sincronicamente (Goldstein et al. 1994).

Tem-se então a formação da imagem do espécime, relacionada aos elétrons 
secundários e aos retroespalhados (retrodispersados). Estes últimos, em função da sua intensidade, revelam as diferentes intensidades luminosas de várias áreas da superfície da amostra. Os elétrons retroespalhados refletem também as diferenças de número atômico dos elementos presentes nas fases analisadas dependendo da composição química, ou seja, através da emissão de raios $X$ característicos dos elementos que constituem a amostra.

\subsubsection{Montagem das amostras}

As amostras de diamantes estudadas neste trabalho foram coladas em uma fita adesiva de duplaface, presas a um suporte de amostra (Stub), sendo posteriormente "metalizadas" a vácuo com uma película de ouro de 100 a $300 \AA$ de espessura, para permitir uma melhor condutibilidade dos elétrons na superfície do mineral. Em seguida, o conjunto foi colocado no interior de uma câmara de vácuo, sob pressões muito baixas $\left(10^{-4}\right.$ a $10^{-8} \mathrm{~mm}$ de mercúrio), necessárias à condução dos feixes de elétrons. $O$ conjunto pode ser movimentado nas direções $X, Y$ e $Z$, por meio de um controle manual (joystick). Durante a análise é possível visualizar a amostra através de um monitor, possibilitando desta forma a escolha dos pontos que se pretende analisar. Os registros obtidos podem ser reproduzidos em fotos de $35 \mathrm{~mm}$ (filme polaróide), em fotos de 120 $\mathrm{mm}$ impressas em papel, ou ainda em disquete (Zip disk).

\subsubsection{Fluorescência ao ultravioleta}

A radiação ultravioleta de ondas longas UVL (3150 a $4000 \AA$ ) foi utilizada em campo para a identificação de possíveis reações fluorescentes. O método consiste em colocar as amostras em um recipiente que é introduzido no analisador. Através de uma abertura lateral observa-se as rações fluorescentes na superfície das amostras. De um modo geral, o mineral em análise reage à incidência da radiação ultravioleta emitindo radiação cujo comprimento de onda (cor) varia com a substância sob análise. No caso do diamante, $50 \%$ aproximadamente reagem à radiação ultravioleta emitindo cores características, em geral de tonalidades azul, amarela ou verde. 


\subsubsection{Análise estatística}

A granulometria, a morfologia e a cor, constituem séries estatísticas envolvendo magnitudes e por isso são chamadas de distribuição de freqüência. Para melhor compreensão e visualização dos resultados destas distribuições, os dados referentes a morfologia e a cor foram representados graficamente e, os dados referentes a granulometria, foram convertidos em informações numéricas e gráficas através da análise estatística.

Esta análise permitiu estudar as propriedades da população em torno do valor médio medido. Assim sendo, utilizou-se como medida de tendência central a média, a mediana e à moda. Como medida de grau de dispersão dos dados em torno do valor médio utilizou-se o desvio padrão, o coeficiente de variação e a assimetria. Os gráficos mais utilizados para ilustrar a distribuição de freqüência dos dados foram o histograma e o diagrama de barras.

$\mathrm{Na}$ elaboração do banco de dados para a análise estatística, utilizou-se o programa Excel. Posteriormente os dados foram transferidos para o programa de análise estatística GSLib (Deutsch \& Journel 1996). 


\section{CONTEXTO GEOLÓGICO REGIONAL}

Na região abrangida por esta dissertação ocorrem litologias integrantes da Faixa Paraguai e da Bacia do Paraná. Os Grupos Cuiabá e Alto Paraguai (Formações Raizama e Diamantino) e o Granito de São Vicente, são unidades da Faixa Paraguai. Os Grupos Paraná, Guatá, São Bento e Bauru e a Formação Aquidauana (correspondente ao norte do Grupo Itararé), fazem parte da Bacia do Paraná. Ao norte da Faixa Paraguai ocorrem rochas do Grupo Parecis, formações Salto das Nuvens e Utiariti. Como unidades quaternárias e terciárias ocorrem as formações Cachoeirinha e Pantanal, além dos Aluviões Atuais. A estratigrafia regional apresentada é o resultado da compilação de vários trabalhos realizados na região por diferentes autores, no decorrer dos últimos anos.

Nesse capítulo será dada ênfase às unidades geológicas sedimentares da Bacia do Paraná que ocorrem nas regiões de Poxoréu e Chapada dos Guimarães, bem como às unidades metassedimentares do Grupo Alto Paraguai que ocorrem nas regiões de Paranatinga, Alto Paraguai e Diamantino (Figura 3.1). Também serão apresentadas algumas características gerais de rochas kimberlíticas que ocorrem nas regiões de Paranatinga e Poxoréu.

\subsection{Faixa Paraguai}

A Faixa de Dobramentos Paraguai situa-se na borda sul-sudeste do Escudo do Guaporé ou Amazônico, tendo à leste o Bloco Rio Apa. Compreende metassedimentos neoproterozóicos, de baixo grau metamórfico, que se estendem sobre o cráton. Apresenta extensão de $1500 \mathrm{~km}$, com exposição em Goiás (sudoeste), Mato Grosso e Mato Grosso do Sul, formando um grande arco com a convexidade voltada para o cráton (Boggiani 1997).

As subdivisões estratigráficas propostas até o momento permitem distinguir três conjuntos. Um inferior representado pelo Grupo Cuiabá (Hennies 1966) caracterizado por metassedimentos pelíticos de caráter turbidítico; um conjunto médio marcado pelo Grupo Corumbá e a Formação Araras, que compreendem sucessões carbonatadas recobrindo sedimentos glácio-marinhos (Formação Puga); e finalmente um conjunto superior representado por arenitos e folhelhos marinho-continentais do Grupo Alto 


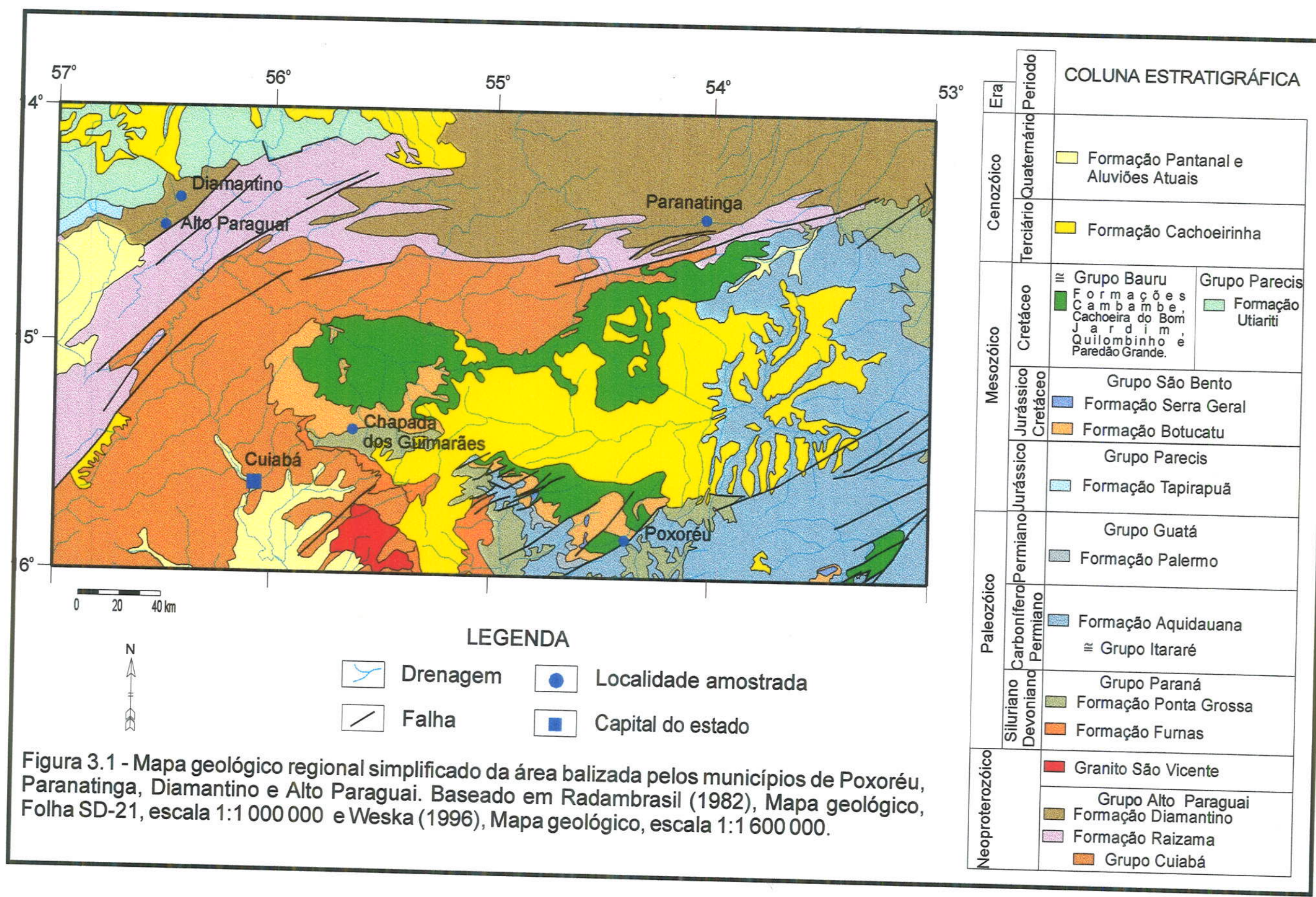


Paraguai (Almeida 1964).

Na região estudada o Grupo Cuiabá corresponde a unidade mais antiga sendo sobreposta pelas unidades do Grupo Alto Paraguai e intrudidas pelo Granito de São Vicente. Os Grupos Cuiabá e Alto Paraguai e o Granito de São Vicente (Almeida 1954), possuem idade Proterozóica Superior segundo datações realizadas por Almeida \& Mantovani (1975) e Barros et al. (1982).

Estas rochas metassedimentares caracterizam a faixa de dobramento formada no final do Pré-Cambriano às margens do Cráton Amazônico. Nesta faixa, tanto os dobramentos como o metamorfismo aumentam em intensidade para o sul/sudeste, em direção ao eixo da bacia (Cordani et al. 1984).

Esta faixa estende-se pela margem sudeste do Cráton do Guaporé até a borda leste do Cráton do Rio Apa. Ao norte é interrompida nas proximidades de Piranhas em Goiás por grandes falhamentos que constituem a continuação do Lineamento Transbrasiliano. Inclui uma seqüência de metassedimentos deformados que foram divididos nas seqüências inferior, carbonatada e superior. A seqüência inferior inclui as Formações Puga, Bauxi e os Grupos Boqui, Jacadigo e Cuiabá; a carbonatada compreende os Grupos Corumbá (Serra da Bodoquena e Corumbá) e Miciélago (Bolívia) e a Formação Araras (ao norte da faixa); finalmente a superior formada pelo Grupo Alto Paraguai (Formação Raizama e Diamantino), conforme Alvarenga \& Trompette (1994).

A história sedimentar da Faixa Paraguai iniciou-se no Proterozóico Superior com a instalação da Bacia Cuiabá na margem tectonicamente instável do cráton e sob influência glacial (Almeida 1984). Este mesmo autor apresentou uma síntese tectonoestratigráfica para a Faixa Paraguai, definindo três domínios estruturais: as brasilides metamórficas, que são zonas ortotectônicas da faixa variando de muito a pouco metamorfizadas, da qual faz parte o Grupo Cuiabá; as brasilides não metamórficas (zona estrutural imediatamente adjacente ao cráton caracterizada por dobramentos lineares, falhamentos inversos e/ou de empurrão com vergência para o cráton e metamorfismo incipiente ou ausente); e o antepaís cratônico com suas coberturas sedimentares (zona geotectônica marginal a faixa de dobramentos). 0 Grupo Alto Paraguai está incluso nas duas últimas zonas estruturais.

As denominações zona interna e externa, correspondendo respectivamente às brasilides metamórficas e não metamórficas e coberturas cratônicas ou de plataforma, foram utilizadas por Alvarenga (1990). Este mesmo autor subdividiu as unidades 
litoestratigráficas da Faixa Paraguai em três conjuntos sedimentares. A unidade inferior, de origem detrítica, inclui o Grupo Cuiabá, as formações Bauxi, Puga e o Grupo Jacadigo. Ela é caracterizada por diamictitos às vezes associados a turbiditos. A unidade média, essencialmente carbonática, compreende o Grupo Corumbá e a Formação Araras; a unidade superior, também detrítica é representada pelo Grupo Alto Paraguai. Será enfatizado neste trabalho à unidade superior, uma vez que ela encerra as regiões de Paranatinga, Alto Paraguai e Diamantino.

Fechando a evolução geológica da Faixa Paraguai, ocorreram deformações tectônicas brasilianas, mais intensas nas suas porções orientais, seguidas de magmatismo granítico pós-tectônico, com idade ao redor de $500 \mathrm{Ma}$. (Boggiani 1997). Grande parte da faixa se acha encoberta pelos depósitos pós-ordovicianos das bacias do Paraná, Pantanal e da liha do Bananal (Alvarenga 1990).

\subsubsection{Grupo Cuiabá}

O Grupo Cuiabá ocorre nos Estados de Mato Grosso e Mato Grosso do Sul, existindo também algumas ocorrências isoladas em Goiás (Almeida 1984). Na região, seus principais afloramentos ocorrem na província geomorfológica Baixada Cuiabana (Almeida 1964) e, representa a base da Faixa Paraguai e da coluna estratigráfica do flanco noroeste da Bacia do Paraná.

É caracterizado por rochas metamórficas de baixo grau (fácies xisto-verde) intensamente dobradas pelos eventos tectônicos do Ciclo Brasiliano. Entre as litologias presentes destacam-se micaxistos, filitos, quartzitos, metadiamictitos, metapelitos, metarenitos e metarcóseos, metaconglomerados e, subordinadamente calcários e mármores.

Almeida (1954) descreveu a Série Cuiabá ressaltando o predomínio dos filitos. Em 1964 esse mesmo autor separa os conglomerados que ocorrem em Jangada em uma nova unidade denominada Grupo Jangada, que é mais novo e glacial. Vieira (1965) dividiu a Série Cuiabá em três subunidades estratigráficas, sendo que na superior e inferior ocorrem o predomínio de filitos, sendo a média constituída por metaconglomerados. Hennies (1966) usou a denominação de "Grupo" em substituição à "Série" Cuiabá.

Posteriormente Guimarães \& Almeida (1972) referem-se à seqüência usando a 
categoria Grupo e a dividem em cinco subunidades litológicas, listadas da base para o topo em metaconglomerados e quartzitos, filitos e filitos ardosianos, quartzitos, metagrauvacas e metarcósios e metassiltitos com "seixos pingados".

Figueiredo \& Olivatti (1974), Ribeiro Filho et al. (1975), Corrêa et al. (1976) e Luz et al. (1980) mapearam grande parte do Grupo Cuiabá, mantendo-o no entanto indiviso. Nogueira et al. (1978) reconhecem o predomínio de micaxistos e filitos e agrupam as litologias mapeadas em duas grandes subunidades, sendo uma inferior detrítica e outra superior carbonática.

Luz et al. (1980) subdividiram este grupo em oito subunidades litoestratigráficas constituídas por filitos sericíticos, metarenitos e metarcósios, filitos conglomeráticos, meta-paraconglomerados, filitos sericíticos, filitos conglomeráticos, metaparaconglomerados e mármores calcíticos e dolomíticos.

As rochas metamórficas do Grupo Cuiabá foram inicialmente consideradas contemporâneas aos sedimentos de cobertura da plataforma cratônica (Almeida 1964). Posteriormente Schobbenhaus et al. (1984) consideraram a existência de uma discordância entre o Grupo Cuiabá e as unidades de cobertura da plataforma.

Alvarenga \& Trompette (1992) e Alvarenga \& Saes (1992) consideraram em parte a interpretação inicial mostrando que os metassedimentos (metadiamictitos, filitos, quartzitos e conglomerados) do Grupo Cuiabá são equivalentes às seqüências menos espessas de diamictitos e arenitos que recobrem o cráton (Formação Puga e Bauxi), os quais foram depositados sob influência da última glaciação neoproterozóica, constituindo a seqüência inferior deste Grupo.

A seqüência carbonatada (Formação Araras) ocorre na porção norte da faixa e encontra-se depositada sobre a unidade basal e/ou sobre o embasamento na área cratônica. Ela está relacionada ao momento de expansão da bacia, provavelmente associada ao final da glaciação. Nas partes mais profundas da bacia, na região de Cuiabá, ocorre a Formação Guia (parte superior do Grupo Cuiabá) que é uma fácies pelito-carbonatada representada pelos metassedimentos filitos, filitos calcíferos, calcários, dolomitos e mármores (Alvarenga \& Trompette1994).

O ambiente deposicional sugerido por Almeida (1954, 1964), Vieira (1965) e Alvarenga $(1988,1990)$ com base na litologia, é de bacia marinha relativamente profunda desenvolvida junto à borda cratônica, influenciada por glaciação e com aporte de sedimentação continental. Não tendo observado material vulcânico Almeida (1964, 1965) sugeriu que a deposição desse grupo ocorreu em ambiente miogeossinclinal de 
grande atividade. Olivatti \& Ribeiro (1976) e Nogueira et al. (1978) sugeriram uma bacia com características eogeossinclinais com base na descoberta de uma seqüência vulcano-sedimentar na região de Bom Jardim em Goiás e em intercalações de metabasitos na regiäo de Bonito (MS).

O Grupo Cuiabá foi afetado por um metamorfismo de baixo grau. Os dobramentos inicialmente abertos da zona externa (Grupo Alto Paraguai) passam a dobras fechadas, inversas e isoclinais ao leste da zona interna (Grupo Cuiabá). O contato entre as zonas estruturais externas e internas dobradas é feito por zonas de falhas inversas de alto ângulo. O contato superior deste grupo com as formações mais jovens da Faixa Paraguai geralmente se faz por grandes falhas (Almeida 1984).

Hasui \& Almeida (1970) atribuíram idade de $540 \mathrm{Ma}$ a um xisto coletado na Estação Ferroviária de Duque Estrada e $639 \mathrm{Ma}$ a uma ardósia da Fazenda Bodoquena, ambas no Mato Grosso do Sul; e a idade de $504 \mathrm{Ma}$ ao Granito São Vicente em Mato Grosso.

\subsubsection{Grupo Alto Paraguai}

O Grupo Alto Paraguai situa-se a norte, na seqüência superior da Faixa Paraguai, ocorrendo principalmente na feição morfológica Província Serrana (Almeida 1964). A denominação de Grupo Alto Paraguai e a primeira coluna estratigráfica desse grupo são devidas ao autor referido, o qual propôs da base para o topo as Formações Raizama, Sepotuba e Diamantino.

Atualmente este grupo é composto pelas Formações Raizama (base) e Diamantino (topo), pois Alvarenga (1990) excluiu as Formações Puga, Bauxi e Araras. As Formações Puga e Bauxi foram incluídas no topo do Grupo Cuiabá, onde segundo o autor acima citado, há somente variação lateral de fácies, e não discordância angular entre o Grupo Cuiabá e a Formação Bauxi (Grupo Alto Paraguai). A Formação Sepotuba, desde os trabalhos de Barros et al. (1982) é considerada uma fácies da Formação Diamantino. Posteriormente Almeida (1984) abandonou a designação Sepotuba, englobando os pelitos desta formação na porção basal da Formação Diamantino, que é também de natureza pelítica.

O Grupo Alto Paraguai constitui uma espessa sucessão de depósitos detríticos com os quais se encerraram os processos sedimentares finalizados pelo Ciclo 
Brasiliano (Almeida \& Hasui 1984). Sua litologia inclui uma espessa seqüência de rochas detríticas, compreendendo arenitos feldspáticos da Formação Raizama, argilitos, siltitos e arcósios da Formação Diamantino, cujas exposições atingem a zona de cobertura cratônica e a zona externa da faixa.

Almeida (1964), Vieira (1965), Figueiredo \& Olivatti (1974) concordam que os depósitos sedimentares do Grupo Alto Paraguai representam uma seqüência regressiva, iniciada com a deposição da Formação Raizama em ambiente marinho costeiro de águas rasas, sujeitas a correntes e com áreas de menor energia onde se acumulavam os pelitos. Este ambiente parece ter predominado durante a deposição da parte inferior da Formação Diamantino (Almeida \& Hassui 1984); com a: continua subsidência da bacia deposicional o ambiente evoluiu de transicional para continental, findando o ciclo sedimentar. Segundo Almeida (1964) esta formação na Serra do Tombador possui uma espessura de $1600 \mathrm{~m}$.

No limite entre o Cambriano Inferior e Médio a Bacia Paraguai foi atingida por processos compressivos jovens da Orogênese Brasiliana, que a deformaram em zonas de diferentes intensidades. Segundo Alvarenga (1988), esse conjunto litológico, ao contrário do Grupo Cuiabá, aparentemente foi dobrado apenas por uma fase do ciclo orogenético Brasiliano.

A Formação Raizama ocorre na província Serrana e na Serra do Padre Inácio, próximo a Cáceres, MT. No seu conteúdo litológico predominam arenitos quartzosos de granulação fina a grossa, com intercalações de lentes de pelitos $e$ de microconglomerados. Nesta unidade são encontradas também estratificações planas e cruzadas, mais raramente, marcas de ondas assimétricas e simétricas (Weska 1996b). O contato com a Formação Araras na porção basal, e no topo com a Formação Diamantino, é do tipo concordante e gradacional (Barros et al. 1982), havendo ao que tudo indica uma zona em que ambas se interdigitam (Almeida \& Hassui 1984 ).

A Formação Diamantino é geograficamente a mais extensa do grupo, aflorando desde as proximidades de Cáceres, através da Província Serrana, até a Serra do Roncador no vale do Rio Araguaia (Olivatti 1981). Esta unidade representa o topo do Grupo Alto Paraguai sendo constituída por rochas sedimentares pouco deformadas. Segundo Barros et al. (1982) é formada por siltitos, argilitos, folhelhos e arenitos finos em vários ciclos sucessivos, evidenciando ritmos regressivos em seu ambiente de sedimentação. Nas porções arenosas e maciças é muito comum a ocorrência de blocos com superfícies semimesféricas, que segundo este mesmo autor, representam 
estruturas típicas de sobrecarga que, com o efeito do intemperismo, desenvolvem esfoliação esferoidal.

Segundo Hennies (1966) essa formação é constituída de uma intercalação de folhelhos, siltitos e arcósios, com espessura que pode atingir mais de $3.000 \mathrm{~m}$ de sedimentos. $\mathrm{Na}$ sua parte superior ocorrem solos lateríticos de idade quaternária (Barros et al. 1982). A estratificação planoparalela é a predominante na sedimentação fina enquanto os arcóseos, geralmente maciços, podem apresentar estratificações do mesmo tipo ou ainda cruzada. São comuns as marcas onduladas de corrente ou onda em uma ou mais direções. Estruturas do tipo clay balls são também observáveis nos arcóseos como pequenas aparas tabulares de folhelho, além de brechas intraformacionais com blocos pouco ou não arredondados de litologia lamítica (Almeida \& Hasui 1984).

Na parte inferior desta formação houve predomínio de ambiente marinho até que o recuo do mar causou o aparecimento de um ambiente de transição, que por fim tornou-se totalmente continental (Almeida \& Hassui 1984). O contato inferior da Formação Diamantino com os arenitos da Formação Raizama é concordante e transicional. O superior com os sedimentos da Formação Cachoeirinha e com os Aluviões Atuais é discordante erosivo.

Segundo Barros et al. (1982), datações realizadas em folhelhos da Formação Diamantino revelaram idade de $547 \pm$ Ma mostrando que o Grupo Alto Paraguai é do Pré-Cambriano Superior. Cordani et al. (1984) datou amostras de rocha total desta formação obtendo uma isócrona de $660 \pm 60 \mathrm{Ma}$.

\subsubsection{Granito São Vicente}

O corpo intrusivo e pós-tectônico, localiza-se na Serra de São Vicente a leste de Cuiabá (Figura 3.1). Está exposto na porção oriental da Faixa Paraguai, sendo intrudido no Grupo Cuiabá. Possui em suas bordas faixas de hornfels resultantes do metamorfismo de contato (Almeida \& Hassui 1984). Apresenta dimensões batolíticas, achando-se em parte encoberto pela Formação Furnas. Trata-se de um corpo maciço de cor rosa e textura porfirítica, sendo cortado por diques de aplito e diabásio (Luz et al. 1980).

O contato inferior desse maciço com os metassedimentos do Grupo Cuiabá é 
termometamórfico; já o superior ocorre por discordância litológica erosiva com os sedimentos das Formações Furnas, Cachoeirinha e Pantanal (Barros et al. 1982).

Através dos dados analíticos Rb/Sr obtidos por Almeida \& Mantovani (1975) e recalculados por Barros et al. (1982), a idade obtida para esse maciço granítico situase no limite entre o Cambriano e o Ordoviciano.

\subsection{Bacia do Paraná}

A Bacia do Paraná é constituída por rochas sedimentares associadas às lavas basálticas da Formação Serra Geral. Localiza-se na Plataforma Sul-Americana, na região centro-leste da América do Sul e tem aproximadamente $1.000 .000 \mathrm{~km}^{2}$. Na América Latina estende-se pelo Brasil, Argentina, Uruguai e Paraguai. No Brasil ocorre nos estados de Mato Grosso, Mato Grosso do Sul, Minas Gerais, Goiás, São Paulo, Paraná, Santa Catarina e Rio Grande do Sul (Schobbenhaus et al. 1984).

Sua evolução ocorreu durante o Paleozóico e o Mesozóico abrigando um registro estratigráfico temporalmente posicionado entre o Neo-Ordoviciano e o Neocretáceo, documentando assim 400 milhões de anos da história geológica fanerozóica dessa região do planeta (Milani \& Ramos 1998). As rochas sedimentares desta unidade foram depositadas, com idades variando entre o Siluro-Ordoviciano e o Cretáceo. As lavas basálticas intrudiram durante o Jurássico/Cretáceo, representando a maior manifestação de vulcanismo até o momento conhecida no globo, cobrindo aproximadamente $1.200 \mathrm{~km}^{2}$ (Piccirillo \& Melfi 1988).

Esta bacia implantou-se diretamente sobre áreas formadas ou reativadas durante o Proterozóico Superior (Ciclo Orogênico Brasiliano), tendo sido recoberta por sedimentação paleozóica. Compreende uma seqüência sedimentar clástica continental e marinha (devoniana), seguida por uma seqüência marinha e continental do Paleozóico Superior (de ambiente glacial no seu início e flúvio-lacustre no seu término), e uma terceira seqüência sedimentar continental, que recobre as anteriores, de ambiente semi-árido, à qual encontram-se associados derrames de lavas basálticas toleíticas de idade juro-cretácica (Cordani et al. 1984).

Segundo Zalán et al. (1990), no final do ciclo Brasiliano, a diminuição dos esforços tectônicos juntamente com o resfriamento da crosta continental recém formada, teriam sido suficientes para iniciar um processo de subsidência, levando à 
deposição da primeira seqüência sedimentar durante o Siluriano. Já Milani (1994) considera que a subsidência inicial desta bacia ocorreu durante a reativação das feições tectônicas de direções NE-SW no Ordoviciano Superior.

A sedimentação ocorreu num ambiente pouco perturbado por fenômenos tectônicos, e como conseqüência, as unidades litoestratigráficas apresentam grande continuidade lateral, com pequenas variações faciológicas. No entanto, segundo Soares et al. (1973), isto não se verifica com as formações depositadas sob influência glacial (Grupo Itararé), ou com as áreas marginais da bacia, em que a subsidência foi muito lenta em relação ao centro. Nesse caso, os processos erosivos nos episódios de soerguimento foram mais intensos resultando um registro sedimentar incompleto do tempo geológico (In: Schobbenhaus et al. 1984).

Segundo Cordani et al. (1984) esta bacia está circundada por terrenos altamente estruturados, quase sempre faixas metassedimentares do Proterozóico Superior (Ciclo Brasiliano) a saber: o Geosinclínio Paraguaio e os sistemas Ribeira/Dom Feliciano, do Ciclo Brasiliano, respectivamente à noroeste e à sudeste; e os metassedimentos do Grupo Araxá e rochas relacionadas ao Ciclo Uruaçuano à norte/nordeste.

No desenvolvimento da sua borda norte, onde esta bacia possui como substrato regional rochas pertencentes ao Grupo Cuiabá, são registrados parte dos eventos da sua seqüência deposicional. Das mais antigas para as mais jovens temos as unidades litoestratigráficas paleozóicas do Grupo Paraná, com as Formações Furnas e Ponta Grossa (Barros et al. 1982), recobertas discordantemente pelas litologias das Formações Aquidauana (Buerlen 1956) e pela Formação Palermo (White 1908). Como unidades mesozóicas e de topo da bacia, temos na região o Grupo São Bento (Mühlmann 1974), com a Formação Botucatu, além de um pacote equivalente ao Grupo Bauru que Weska et al. (1996) dividiram em quatro unidades litoestratigráficas, as Formações Paredão Grande, Quilombinho, Cachoeira do Bom Jardim e Cambambe.

A coluna estratigráfica dos registros relativos à Bacia do Paraná nas regiões de Poxoréu e Chapada dos Guimarães é incompleta, pelo fato dessas regiões estarem situadas na borda NW da bacia (Figura 3.2).

No topo da coluna geológica regional, ocorrem a Formação Cachoeirinha (Gonçalves \& Schneider 1970) de idade terciária, a Formação Pantanal (Oliveira \& Leonardos 1943) e os Aluviões Atuais (Barros et al. 1982), ambas consideradas de idade quaternária. 


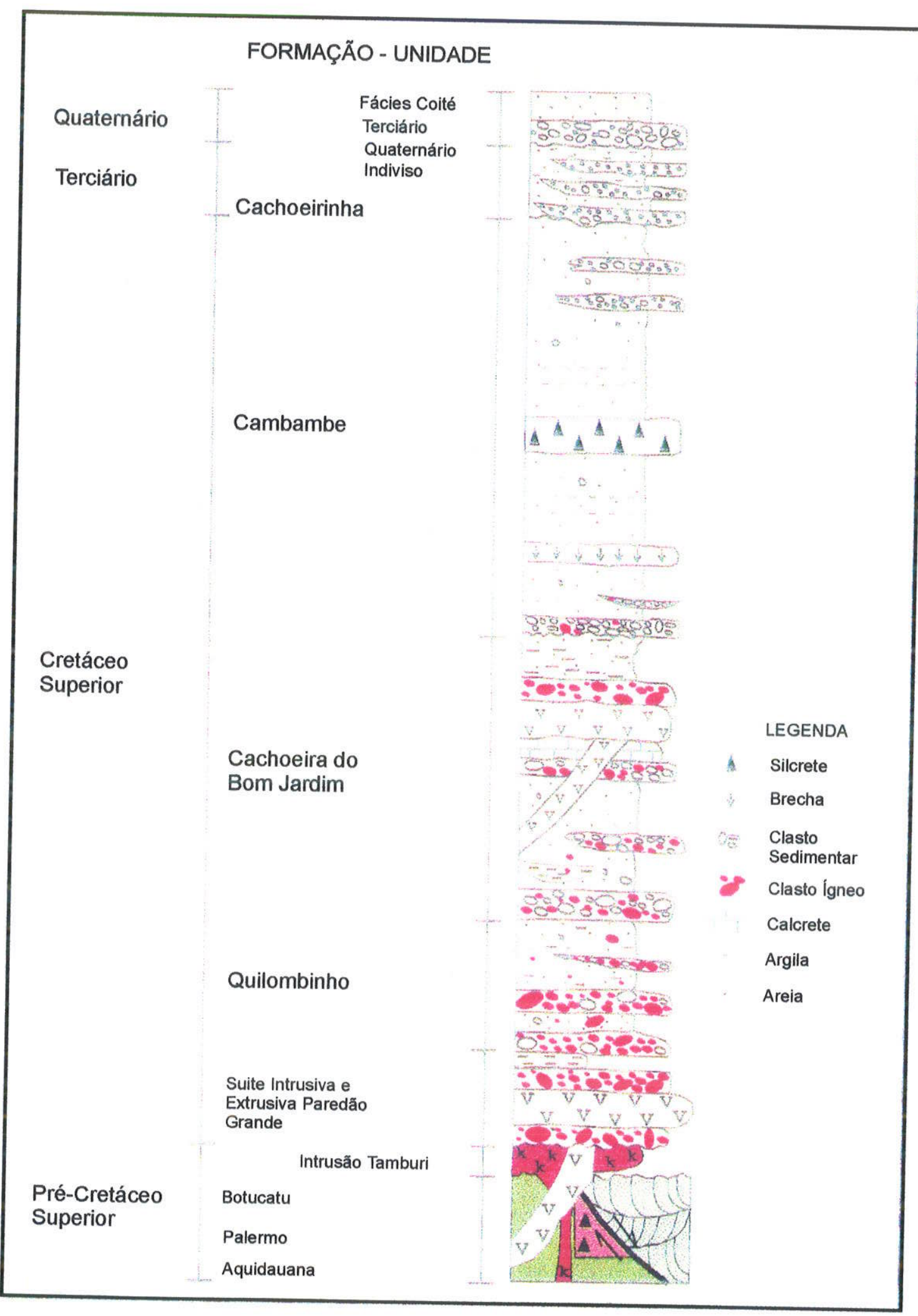

Figura 3.2 - Coluna estratigráfica da região compreendida entre os Municípios de Poxoréu, Paranatinga e Chapada dos Guimarães. Extraido de Weska (1996a). 


\subsubsection{Grupo Paraná}

A Formação Furnas marca o início da deposição dos sedimentos da Bacia do Paraná no Paleozóico, sendo portanto sua unidade basal. É constituída por arenitos cauliníticos de granulação média a grossa e secundariamente por conglomerados. Em direção ao topo ocorre uma gradação para arenitos finos, argilitos e siltitos micáceos (Schneider et al. 1974; Bergamachi 1992; In: Milani 1994). Drago et al. (1981) descreveram uma secção nas adjacências da cidade de Barra do Garças, onde observaram a ocorrência de fragmentos de xistos e filitos do Grupo Cuiabá inseridos nesta unidade.

As estruturas sedimentares predominantes na porção basal desta unidade são as estratificações cruzadas de pequeno porte e laminação cruzada, que ocorrem em arenitos grossos a médios. Na porção intermediária ocorrem, em camadas de arenito, estratificações cruzadas planares ou acanaladas de médio a grande porte e grandes canais truncantes preenchidos lateralmente que gradam para laminações plano paralelas e laminação cruzada de ondas. No topo da seqüência ocorrem bioturbações de invertebrados, em vários graus de intensidade, em arenitos finos a muito finos (Barros et al. 1982; Schubert 1994).

O ambiente deposicional é considerado de origem fluvial continental por Ludwing \& Ramos (1965, In: Schobbenhaus et al. 1984) e marinho por Almeida (1954), Sanford \& Lange (1960), Bigarella et al. (1966), Lange \& Petri, (1967) e Bigarella \& Salamuni (1967), todos referidos em Schobbenhaus et al. (1984), além de Schubert (1994) e Assine \& Petri (1994). Contudo, Bergamachi (1994), considera mais evidente que tenha ocorrido uma deposição fluvial na base da seqüência, com uma gradação para ambiente costeiro em direção ao topo, marcando uma transição para ambiente marinho. Isto ocorreu devido à movimentação essencialmente ascendente do nível relativo do mar na borda leste da Bacia do Paraná, formando os depósitos transicionais costeiros do topo da Formação Furnas, que foram sendo recobertos concordantemente pelos depósitos marinhos rasos da base da Formação Ponta Grossa.

A Formação Furnas apresenta segundo Petri \& Fúlfaro (1983) um conglomerado basal com aproximadamente $1 \mathrm{~m}$ de espessura e diversos tipos de arenitos. Ela seria representativa de um sistema deposicional fluvial (Northfleet et al. 1969), apresentando depósitos de cabeceiras de leques aluviais e fácies de um sistema fluvial 
anastomosado (Popp \& Popp 1986), ou ainda como sugerem Petri \& Fulfaro (1983), produto de um ambiente litorâneo de águas rasas (Gonzaga \& Tompkins 1991).

Segundo Borghi (1998), a análise das fácies da Formação Furnas na borda leste da Bacia do Paraná (Estado do Paraná) permitiram interpretar esta unidade como sendo o produto da deposição marinha de areias e cascalhos flúvio-costeiros durante o Eodevoniano.

Na região de Chapada dos Guimarães (Figura 3.1) a Formação Furnas assentase em discordância angular sobre as rochas do Grupo Cuiabá e em discordância litológica sobre o Granito de São Vicente (Weska 1996a). O contato superior desta unidade com a Formação Ponta Grossa é concordante e gradacional (Barros et al. 1982; Bergamaschi 1994; Schubert 1994). Segundo Schobbenhaus et al. (1984) ocorre contato discordante na região oeste da Chapada dos Guimarães com a Formação Botucatu e, ao sul de Rondonópolis com o equivalente do Grupo Bauru.

Quanto à idade, a Formação Furnas é anterior ao Devoniano Inferior, que é a idade de deposição da parte inferior da Formação Ponta Grossa (Schobbenhaus et al. 1984).

Segundo Moreira (1998), na região oriental da Chapada dos Guimarães (caverna Aroe Jari) aflora a Formação Vila Maria (Grupo Ivaí), que é uma unidade mais antiga do que a Formação Furnas. Sua sucessão estratigráfica é caracterizada por conglomerados (flúvio-glaciais), conglomerados e arenitos (fácie-de-praia e antepraia, transgressivas), diamictitos e folhelhos (glácio-marinhos) e arenitos (antepraia, regressiva). Foram observadas estruturas de deformação glaciogênicas no intervalo de camadas dos diamictitos e no contato desse intervalo com o de conglomerados e arenitos sotopostos, que são do tipo dobras em bainha, estrias, falhas de deslocamento e superfícies internas de cisalhamento. A partir dessas estruturas e fácies foram interpretados escorregamentos gravitacionais do tipo slump, dentro do sistema deposicional glácio-marinho, causado pelo grande aporte dos sedimentos glaciais (diamictitos).

Baseando-se em estudos sedimentológicos Moreira (1998) postulou a existência de terras altas no embasamento Pré-Cambriano à NW da Bacia do Paraná durante o Siluriano, representadas pela Província Serrana (Almeida 1964) em terrenos da Faixa Paraguai e que seriam a fonte dos glaciares (Moreira 1998). Isso posto, o início da deposição desta bacia na região não seria a Formação Furnas, mas sim a Formação Vila Maria. Esta unidade não está representada no mapa geológico apresentado na 
Figura 31 por questões de escala.

$\mathrm{Na}$ região estudada a Formação Ponta Grossa (unidade superior do Grupo Paraná), sobrepõe-se aos sedimentos da Formação Furnas, aflorando em duas regiões distintas: ao sul (Chapada dos Guimarães e Rondonópolis), à leste (Nova Xavantina e Campinápolis) e à norte-nordeste de Paranatinga. Litologicamente essa formação é constituída por folhelhos, folhelhos siltíticos e siltitos, arenitos finos a muito finos, fossilíferos (Schneider et al. 1974). Na borda noroeste da Bacia do Paraná, os arenitos aparecem em camadas finas individualizadas dentro da seção argilosa (Schobbenhaus et al. 1984). As estruturas presentes são marcas de ondas, estratificações cruzadas planares de pequeno porte, além de fácies heterolíticas (flaser, wavy e linsen) e mosqueadas (Barros et al. 1982; Schubert 1994).

O conteúdo fossilífero desta unidade é bastante rico. Próximo à cidade de Chapada dos Guimarães ocorrem folhelhos fossilíferos com a presença de fauna abundante de braquiópodes, trilobitas, quitinozoários, entre outros, sugerindo condições marinhas na deposição dos sedimentos. Esta unidade representa o sistema marinho raso dominado por ondas normais e de tempestade (Schubert 1994), indicando o avanço do mar sobre o continente durante o Devoniano.

Segundo Sundaram et al. (1997) na região de Placa Nativa próximo a Canarana (Mato Grosso), foi registrada a ocorrência de uma fauna semelhante aquela encontrada no Estado do Paraná. Provisoriamente, foram reconhecidos os gêneros Língula, Orticuloidea, Australocoelia derbyna, Murospirifer (Filo Brachiopoda); Bucanella e Tentaculites (Filo Molusca) e Dalmanites e Calymene (subfilo Trilobita).

Os estudos de macrofósseis realizado por Lange \& Petri (1967, In:Schobbenhaus et al. 1984), quitinozoários e acritarcas por Lange (1967, In:Schobbenhaus et al. 1984) e palinomorfos por Daemon et al. (1967, In:Schobbenhaus et al. 1984), indicaram que a deposição da Formação Ponta Grossa estende-se desde o Devoniano Inferior (Ensiano) até o Devoniano Superior (Fransniano).

O contato entre as Formações Furnas e Ponta Grossa é concordante e gradacional (Barros et al. 1982). Contudo o contato superior da Formação Ponta Grossa com as Formações Aquidauana, Botucatu, Cachoeirinha e com o Grupo Bauru, se dá por discordância erosiva ou por falhas (Schneider et al. 1974). 


\subsubsection{Formação Aquidauana}

Nesta formação, correspondente ao Grupo Itararé no norte da bacia, foram identificados três intervalos estratigráficos em seus sedimentos vermelhos e arroxeados (Gonçalves \& Schineider 1970). O intervalo inferior é constituído por arenitos médios a grossos, conglomerados e diamictitos subordinados; o médio, por siltitos estratificados e secundariamente diamictitos e folhelhos; sendo o superior caracterizado pelo predomínio de sedimentos arenosos. Nas camadas mais finas desta unidade ocorrem ondulações com truncamento no topo da convexidade, sugerindo retrabalhamento por onda de tempestade (Guirro 1991).

Esta unidade está inserida em um arcabouço glaciogênico no qual as geleiras foram as principais responsáveis pelo aporte de sedimentos à bacia, dominados por sistemas deposicionais continentais e transicionais flúvio-eólico, flúvio-deltaico e marinho raso (Milani et al. 1994).

$\mathrm{Na}$ região de Poxoréu, essa unidade é composta por arenitos grossos a finos, conglomeráticos, argilosos ou micáceos, intercalados ciclicamente com lentes de arenitos microconglomeráticos, arenitos argilosos e argilitos, com concreções de cimento de óxido de ferro predominando em direção ao topo (Weska 1996a). Saes et al. (1992) descreveram uma seção glaciogênica da Formação Aquidauana próximo à cidade homônima em Mato Grosso do Sul e a leste de Rondonópolis (Mato Grosso), como sendo uma seqüencia areno-argilosa fluvial.

Segundo Gesicki et al. (1996), ocorrem pavimentos com estruturas de abrasão glacial (estrias) em depósitos da Formação Aquidauana na borda ocidental da Bacia do Paraná, mais precisamente nas porções sul e central de Mato Grosso do Sul. Estas estruturas foram produzidas durante o período de avanço glacial atuante na bacia na época da deposição do início do intervalo superior da formação. Segundo este autor o avanço glacial do intervalo superior desta formação representa o mais importante e derradeiro evento de glaciação continental Gondwânico.

A idade desta formação fol determinada por meio de dados palinológicos tendo sido posicionada no Carbonífero Superior por Daemon \& Quadros (1970, In: Barros et al. 1982). Guirro (1991), considera a Formação Aquidauana como sendo contemporânea aos eventos glaciogênicos que ocorreram em parte dos estados do sul do Brasil, incluindo-a por esta razão no Grupo Itararé. Os contatos litológicos inferior e 
superior, são discordantes e ocorrem respectivamente com o Grupo Paraná (Formações Furnas e Ponta Grossa), com a Formação Botucatu (Grupo São Bento) e com equivalentes do Grupo Bauru.

\subsubsection{Grupo Guatá}

A Formação Palermo ocorre nas cotas topográficas mais elevadas $(720$ a $400 \mathrm{~m}$ em relação ao nível do mar) ao sul e sudeste de Poxoréu, junto à escarpa da falha de Poxoréu, constituindo a estrutura silicificada que sustenta os flancos da estrutura do Alto Coité. A morfologia desses pacotes é tabuliforme, estando as rochas intensamente silicificadas, sendo portanto resistentes ao intemperismo (Weska 1996a).

Segundo Weska (1996a), esta unidade é constituída por conglomerados basais oligomíticos, com seixos de quartzo, apresentando baixo grau de arredondamento. A matriz é areno-siltosa e o cimento silicoso. Calcarenitos oolíticos intercalam-se a pacotes de argila em direção ao topo na região da Estrutura do Alto Coité. Níveis oolíticos e silexitos maciços e com laminações intercaladas de até $1 \mathrm{~cm}$ de espessura nas cores branca e vermelha ocorrem no topo do muro da Falha de Poxoréu. O contato inferior com a Formação Aquidauana e o superior com as unidades TerciárioQuaternário Indiviso, em ambos os casos são discordantes erosivos.

Através de dados palinológicos, Daemon \& Quadros (1969, In: Barros et al. 1982) propuseram uma idade permiana média a superior para essa formação. Gonçalves \& Schneider (1970) sugeriram que a idade dessa unidade situa-se entre o Permiano Médio e o Superior.

\subsubsection{Grupo São Bento}

A Formação Botucatu constitui a parte basal do Grupo São Bento, representando um episódio de desertificação na Bacia do Paraná (Zalán et al. 1990). Cobre aproximadamente $1.300 .000 \mathrm{~km}^{2}$, sendo considerado um dos maiores depósitos de sedimentos continentais do mundo (Milani et al. 1994). Nas regiões estudadas ocorre na Chapada dos Guimarães e em Poxoréu (Figura 3.1).

Segundo Barros et al. (1982), os tipos litológicos desta unidade são arenitos vermelhos com estratificações cruzadas e plano-paralelas de médio a grande porte. 
Segundo Schneider et al. (1974), as características texturais, tais como grãos foscos, associadas às estruturas primárias observadas, indicam deposição eólica em ambiente desértico.

Em direção ao topo desses depósitos eólicos começam a aparecer intercalações com os derrames de lava basáltica da Formação Serra Geral, na porção central da bacia, marcando os primeiros estágios de manifestação magmática da ruptura do Gondwana e abertura do Oceano Atlântico Sul (Milani et al. 1994)

Por relações estratigráficas atribui-se idade jurássica para esta formação, uma vez que ela está situada imediatamente abaixo dos derrames basálticos do JurássicoCretáceo e acima da Formação Rosário do Sul (Membro Santa Maria) de idade triássica média a superior (Schobbenhaus et al. 1984).

Seu contato inferior na região de Chapada dos Guimarães (Weska 1987) ocorre por discordância angular com o Grupo Cuiabá. Na região de Poxoréu Barros et al. (1982) consideram que o contato inferior com a Formação Aquidauana é controlado por falhamentos gravitacionais. Nestas duas regiões, o contato superior com sedimentos equivalentes ao Grupo Bauru (Weska 1987, 1996a) é discordante ou por falhamentos. As rochas da Formação Botucatu na Chapada dos Guimarães também constituem as rochas encaixantes para diques, assim como são sotopostas por depósitos das explosões e pelos derrames da Formação Paredão Grande (Weska 1996a e Weska et al. 1996).

As lavas basalticas da Formação Serra Geral sobrepõem gradativamente os arenitos eólicos da Formação Botucatu, marcando os primeiros estágios da manifestação magmática da ruptura do Godwana e abertura do Oceano Atlântico Sul (Milani et al. 1994). Este fenômeno se manifestou através de uma sucessão de vários derrames, onde as lavas cobriram as rochas sedimentares da Bacia do Paraná, intrudindo entre as várias seqüências de sedimentos formando uma intrincada rede de diques e sills.

Segundo Piccirilo \& Melfi (1988) o vulcanismo Serra Geral com derrames superpostos, geralmente subhorizontais pode ser representado por três grandes grupos de rochas: a) basalto tolético representando $90 \%$ do volume total de rochas, b) andesito toleítico representando $7 \%$ e c) riodacito-riolito representando $3 \%$. O número de derrames é variável de uma região para outra, sendo citados mais de 20 ocorrências em determinadas áreas. A espessura total é também variável, sendo da ordem de 350 metros nas bordas da bacia, podendo atingir até 2.000 metros nas 
porções mais centrais (Milani 1994).

Os primeiros derrames são exclusivamente basálticos e possuem idades que se situam entre 130 e $150 \mathrm{Ma}$; os derrames intermediários apresentam idades entre 123 a $130 \mathrm{Ma}$, enquanto as últimas manifestações apresentam idades entre 118 a $125 \mathrm{Ma}$ (Schobbenhaus et al. 1984).

Os derrames basálticos da Formação Serra Geral cobrem 75\% da Bacia do Paraná, constituindo o Planalto Meridional Brasileiro. Essa seqüência forma a maior área de rochas ígneas expostas continuamente no Brasil, sendo considerado também um dos mais importantes eventos vulcânicos da Terra (Almeida 1986). Recobrem parte do Rio Grande do Sul, Santa Catarina, Paraná, São Paulo, Goiás, Mato Grosso do Sul e Minas Gerais, tendo ainda continuidade ao sul do Paraguai, norte da Argentina e oeste do Uruguai. Inúmeras outras ocorrências, como por exemplo, na Chapada dos Guimarães, Dom Aquino e Poxoréu, também consideradas e mapeadas como correlatas ao evento Serra Geral, foram datadas por método $\mathrm{Ar}^{40} / \mathrm{Ar}^{39}$ por Gibson et al. (1997), os quais obtiveram idade de 83,9 Ma. Portanto, estes autores mostraram que estas rochas não são equivalente a Formação Serra Geral. Desta forma, os únicos eventos contemporâneos ao magmatismo Serra Geral, na região abrangida por esta dissertação, são os kimberlitos de Paranatinga, cujas idades obtidas por Davis (1977) e Heaman et al. (1998), são de 121,1 Ma e entre 123 - $126 \mathrm{Ma}$, respectivamente.

\subsubsection{Unidades equivalentes ao Grupo Bauru}

Bauer \& Largher (1958) apresentaram as primeiras citações sobre a ocorrência de rochas equivalentes a esse grupo no Estado de Mato Grosso. Weska (1987) e Weska et al. (1988) dividiram as rochas equivalentes a esse grupo na região da Chapada dos Guimarães nas fácies Quilombinho (basal), Cachoeira do Bom Jardim (intermediária) e Cambambe (topo) elas teriam sido depositadas a partir de leques aluviais, em paleorrelevo do tipo meio-gráben, sob condições climáticas áridas a muito áridas.

Coimbra (1991) elevou as fácies definidas por Weska (1987) e Weska et al. (1988) à categoria de formação, e ao mesmo tempo propôs a fusão das fácies Quilombinho e Cachoeira do Bom Jardim em uma nova unidade denominada Formação Córrego Ribeirão Boiadeiro. Essa formação e a Fácies Cambambe, também 
elevada à categoria de formação, comporiam bacias individualizadas do tipo pull apart.

Weska et al. (1993) estenderam para região de Poxoréu o mapeamento destas fácies e propuseram a formalização do Grupo Bauru no Estado do Mato Grosso, que seria constituído pelas Formações Quilombinho (basal), Cachoeira do Bom Jardim (intermediária) e Cambambe (topo), com uma evolução do tipo rifte, onde a Formação Quilombinho representa o estágio rift da bacia. Em trabalho mais recente, Weska et al. (1996) propuseram uma nova divisão para as rochas equivalentes ao Grupo Bauru em Mato Grosso, dividindo-o em quatro unidades litoestratigráficas: formações Paredão Grande, Quilombinho, Cachoeira do Bom Jardim e Cambambe, da base para o topo, respectivamente.

Derby (1890, In: Weska 1996a) propôs uma idade cretácea para os litotipos desta unidade que continham fósseis das ordens Dinossauria e Quelônia, e Roxo (1937 In: Weska 1996a) uma idade cretácea superior. Segundo Weska (1987) e Weska et al. (1993) tais jazigos fossilíferos ocorrem na Formação Cambambe.

No Estado de Mato Grosso ocorrem derrames basálticos nas regiões de Chapada dos Guimarães, Poxoréu e Dom Aquino. Segundo Weska (1996a), Weska et al. (1996) e Gibson et al. (1997), tratam-se de basaltos alcalinos do tipo OIB, datados em 83,9 $\pm 0,4 \mathrm{Ma}$. através do método $\mathrm{Ar}^{40} / \mathrm{Ar}^{39}$ a laser, sem qualquer relação com os basaltos da Formação Serra Geral e nem com as rochas básicas-ultrabásicas do Grupo Iporá. Weska et al. (1996) posicionaram esses derrames na Formação Paredão Grande, situada na base do pacote equivalente ao Grupo Bauru.

Os contatos deste grupo com as unidades inferiores (formações Botucatu, Palermo, Aquidauana e Ponta Grossa) são discordantes erosivos (Barros et al. 1982; Weska 1987; Weska et al. 1988; Weska 1996a). O contato superior também é discordante erosivo e e ocorre com as Formações Cachoeirinha, Pantanal e com os Aluviões Atuais. Segundo Weska (1987) foi observado o contato basal do equivalente ao Grupo Bauru com rochas das formações Raizama (Grupo Alto Paraguai) próximo a Paranatinga, Aquidauana (correlata ao Grupo Itararé) na região de Poxoréu e, Botucatu (Grupo São Bento) na região de Chapada dos Guimarães.

A Formação Paredão Grande é constituída por um conjunto de rochas vulcânicas incluindo piroclásticas de granulação fina a grossa, derrames de olivina basalto, traquiandesito interdigitado nas formações Quilombinho e Cachoeira do Bom Jardim e, diques de basalto alcalino de espessuras variadas (Weska et al. 1996).

Os eventos magmáticos relacionados à Formação Paredão Grande ocorrem na 
forma de agrupamentos de derrames pequenos em Dom Aquino, derrames de grandes extensões em Poxoréu e Chapada dos Guimarães, ou ainda como enxames de diques em Paredão Grande e Meruri (Weska et al. 1996). Como já foi mencionado, a idade $83,9 \pm 0,4 \mathrm{Ma}$ destes basaltos difere daquela da Formação Serra Geral, cuja idade oscila em torno de $125 \mathrm{Ma}$ (Weska et al. 1996).

A Formação Quilombinho representa um sistema de leques aluviais desenvolvidos sobre a Formação Paredão Grande, caracterizam-se pela presença de conglomerados, arenitos e lentes de argila derivados de eventos deposicionais cíclicos. Os clastos dos conglomerados são constituídos essencialmente por rochas de composição basáltica (Weska et al. 1996).

Segundo Weska et al. (1996), esta formação reúne depósitos de borda de escarpa na forma de conglomerados polimíticos nos quais $90 \%$ dos clastos são componentes vulcânicos da Formação Paredão Grande, sendo os $10 \%$ restantes representados por seixos e matacões da Formação Raizama, Aquidauana, Palermo e Botucatu. Segundo este mesmo autor, esses conglomerados exibem gradação inversa com vários ciclos de alternância entre os conglomerados e lentes de argila e arenitos argilosos com estratificação cruzada.

A Formação Cachoeira do Bom Jardim, igualmente um sistema aluvial com leques e canais entrelaçados, mostra redução de contribuição vulcânica, com o aparecimento de calcretes nas porções intermediárias. É definida como uma seqüência de rochas detríticas, com granulação grossa (conglomerado) na base, evoluindo progressivamente na porção intermediária para arenitos conglomeráticos e arenitos. No topo ocorrem calcretes com arenitos finos (Weska et al. 1996).

Segundo Weska et al. (1996) esta formação é constituída também por conglomerados polimíticos, cíclicos com gradação inversa, interdigitados com lentes de argilas, arenitos e arenitos argilosos. Com relação aos clastos, aproximadamente $50 \%$ são derivados de rochas vulcânicas, sendo a outra metade representada por clastos derivados de rochas sedimentares. Uma das características desta formação é a presença de uma carbonatação intensa traduzida pela recristalização do carbonato de cálcio em drusas e cristais isolados de calcita, além de crosta carbonáticas (calcretes).

Os sedimentos desta formação estão relacionados a eventos deposicionais cíclicos, onde a deposição ocorreu sob condições de clima semi-árido a árido e também com predomínio de regime de enxurradas (Weska et al. 1993).

A Formação Cambambe, situada no topo do pacote, reproduz os ambientes 
anteriores de leques aluviais, com a substituição dos perfis de solo de calcrete por silcretes, onde são encontrados ossos de répteis das ordens Dinossauria e Quelônia. É constituída por conglomerados cíclicos basais, arenitos, silcretes e arenitos finos a microconglomeráticos em direção ao topo da unidade (Weska et al. 1996). Segundo Rosa et al. (1991), essa unidade representa a fácies distal de um leque aluvial depositado em uma depressão continental. Estes mesmos autores consideram que as silicificações que ocorrem nesta formação são de grande extensão sendo constituídas por camadas de sedimentos arenosos e silcretes com pouca argila.

Segundo Weska et al. (1996), os seixos e alguns matacões são derivados predominantemente de rochas sedimentares, sendo raros os clastos vulcânicos. A presença de silcretes e cristais de quartzo em geodos evidenciam uma silicificação intensa nesta formação. A idade desta formação com base em seu conteúdo fossilífero é cretácea superior (Roxo 1987, In: Weska 1996a).

\subsection{Bacia dos Parecis}

Ao norte da Faixa Paraguai ocorre a Bacia Intracratônica dos Parecis (Fanerozóico), preenchida de sedimentos, em sua major parte considerados como Paleozóicos e secundariamente mesozóicos e cenozóicos (Siqueira 1989). Desenvolveu-se inicialmente em um rifte intracratônico, passando para bacia do tipo sinéclise ainda no paleozóico. As seqüências tidas como paleozóicas são marinhas e lacustrinas; as mesozóicas (Grupo Parecis) são continentais, fluviais e eólicas.

Siqueira (1989) e Siqueira \& Teixeira (1993) compartilharam esta unidade em três sub-bacias, nomeadas de oeste para leste, Rondônia, Juruena e Alto Xingu. Segundo estes mesmos autores as unidades geológicas pertencentes a esta bacia são da base para o topo as Formações Cacoal (Siluriano), Furnas e Ponta Grossa (Devoniano), Pimenta Bueno (Carbonífero Superior a Permiano), Botucatu (Triássico), Anari e Tapirapuã (Jurássico), Salto das Nuvens e Parecis (Cretáceo Superior) e Araguaia (Terciário-Quaternário).

$\mathrm{Na}$ região norte de Alto Paraguai, Diamantino e Paranatinga ocorrem sedimentos do Grupo Parecis (formações Salto das Nuvens e Utiariti), constituídos por níveis conglomeráticos intercalados com arenitos finos e médios de cor branca e vermelha, em matriz aparentemente arcoseana. Nos níveis conglomeráticos 
predominam seixos de quartzo, quartzito, silexito, arenitos grossos de textura sacaróide e subordinadamente de basalto; o arredondamento dos seixos é bom e a esfericidade é baixa, apresentando seixos achatados (Siqueira 1989).

As relações de contato do Grupo Parecis em Diamantino, com metassedimentos do Grupo Alto Paraguai é por discordância litológica, angular, erosiva e temporal, o mesmo ocorrendo no contato com os Aluviões Atuais (Carvalho et al. 1991).

\subsection{Formação Cachoeirinha}

Oliveira \& Mülhmann (1965) fizeram a primeira descrição desta formação na época denominada unidade " $\mathrm{C}$ ". O termo Formação Cachoeirinha foi proposto posteriormente por Gonçalves \& Schneider (1970).

Segundo Drago et al. (1981), esta unidade é constituída de materiais arenoargilosos inconsolidados, exibindo cores vermelha-alaranjadas ou às vezes róseaclaras. A granulometria varia de fina a média com os grãos de quartzo em geral angulosos a subangulosos, ocorrendo raramente lentes de cascalhos em matriz arenosa como produto de depósitos residuais de canais. Na parte mais inferior são encontrados comumente níveis de concreções ferruginosas ou bolsões de cangas lateríticas. Segundo Weska (1996a), esta unidade da base para o topo é constituída por lentes de cascalho, areias cascalhosas, areias argilosas, areias, argilas e crostas lateríticas (ferricretes).

Na região de Chapada dos Guimarães, segundo Weska (1987) e Weska et al. (1991), ocorrem dois conjuntos litológicos individualizados nas coberturas terciárias que se sobrepõem ao Grupo Bauru. Estes conjuntos marcam os processos erosivos e deposicionais relacionados à evolução da bacia intracratônica do Pantanal. O primeiro é representado pela Formação Cachoeirinha (basal), constituída por lentes de clastos grossos, areias e argilas, enquanto o segundo constitui a Fácies Estiva (topo) formada por clastos grossos com matriz areno-argilosa. Segundo Weska (1987), nesta região a Formação Cachoeirinha é fluvial (base) e lacustrina (topo), estando associada a movimentos de massa (mass moviments). Já a Fácies Estiva reflete fluxos de lama e de clastos grossos (debris flow). O conjunto é interpretado como parte de um leque aluvial terciário.

A Formação Cachoeirinha recobre quase todas as unidades da borda ocidental 
da Bacia do Paraná, sendo o contato erosivo com as rochas dos Grupos Cuiabá e Alto Paraguai, Granito de São Vicente, Formações Furnas, Ponta Grossa, Aquidauana, Palermo e Botucatu (Barros et al. 1982), e o equivalente do Grupo Bauru na região (Weska 1987; Weska et al. 1991). O contato de topo com a Fácies Estiva e as coberturas quaternárias também é por discordância erosiva (Weska 1987; Weska et al. 1991). A idade da Formação Cachoeirinha segundo interpretações de Schobbenhaus et al. (1984) é pliocênica.

\subsection{Formação Pantanal}

A Formação Pantanal denominada por Oliveira \& Leonardos (1943) é constituída por sedimentos aluvionares inconsolidados e parcialmente lateritizados. Weska et al. (1984) subdividiram informalmente os pacotes situados em terraços laterais das drenagens da Bacia do Alto Paraguai na região entre Diamantino e Arenápolis (MT), nos niveis T1,T2 e T3.

A Formação Pantanal recobre discordantemente rochas do Grupo Cuiabá e o Granito de São Vicente localizados na Depressão Cuiabana e, também rochas da Bacia do Paraná, como a Formação Botucatu (Barros et al. 1982) e do equivalente do Grupo Bauru (Weska 1987). Tendo Almeida (1965a, In: Barros et al. 1982) descrito a presença de mamíferos fósseis pleistocênicos na zona norte do Pantanal, a idade desta formação é plestocênica.

\subsection{Aluviões atuais}

Os aluviões atuais são encontrados junto aos canais atuais e às planícies de inundação das principais bacias de drenagens que escoam em direção à Bacia do Prata ao sul, e Bacia Amazônica ao norte, de que são exemplo os rios Cuiabá e Paraguai, e os rios das Mortes, Xingu e Teles Pires, respectivamente (Weska 1996a).

Os depósitos atuais encontram-se ainda em fase de deposição nas planícies aluvionares dos grandes rios e seus tributários. Compõem-se de areias, siltes, argilas e cascalhos, dando origem a depósitos de canal, depósitos de barra em pontal e de transbordamento (Barros et al. 1982).

As características encontradas nos depósitos quaternários, segundo Weska 
(1987) e Weska et al. (1996), correspondem àquelas atribuídas às acumulações coluviais e aluviais de ambiente fluvial, havendo estreita relação dos depósitos com a rede de drenagem local.

Coberturas inconsolidadas e/ou lateritizadas que ocupam o topo da coluna geológica regional são contemporâneas ao desenvolvimento da Bacia Intracratônica do Pantanal a partir do Terciário até os dias atuais, recobrindo indistintamente as rochas anteriormente descritas (Weska 1996a).

\subsection{Kimberlitos da região de Paranatinga e Poxoréu}

Segundo Fragomeni (1976), existe na região de Paranatinga uma importante província kimberlítica ocupando uma área de aproximadamente $4000 \mathrm{~km}^{2}$. Na época, o referido autor mencionou a presença de 4 dezenas de intrusões. As intrusões encontram-se posicionadas na depressão interplanáltica de Paranatinga atravessando a seqüência sedimentar na porção pouco deformada da Formação Diamantino. Fragmentos angulosos de siltitos e arenitos, muitas vezes com bordas carbonatadas, são encontrados frequentemente como xenólitos inclusos nessas brechas kimberlíticas (Costa 1996).

Estes kimberlitos estão localmente controlados por falhas de gravidade de direção geral $\mathrm{N}^{\circ} 0^{\circ}-30 \% \mathrm{~W}$ resultantes dos esforços distensionais do Geossinclíneo Paraguai-Araguaia, (Fragomeni 1976). Portanto, a colocação dos kimberlitos da região de Paranatinga foi condicionada por uma tectônica de fratura que com a reativação cretácica destas linhas de fraquezas, possivelmente facilitou a subida de magmas ultrabásicos/potássicos do manto astenosférico (Costa 1996).

Costa (1996) caracterizou a intrusão Batovi 6, pertencente a esta província, como sendo um kimberlito de fácies diatrema, formado por uma brecha tufácea semelhante na mineralogia, química mineral e litogeoquímica aos kimberlitos do Grupo I (Smith et al. 1985), que correspondem a corpos formados na astenosfera.

Filemon et al. (1997) caracterizaram a intrusão Piranhas 1, integrante também desta província, a qual segundo os autores possui uma paragênese semelhantes a alguns kimberlitos do Brasil e da África do Sul. A presença de grande quantidade de xenólitos de rochas encaixantes, a presença de material tufáceo, bem como as dimensões relativamente grandes do corpo sugerem tratar-se de uma intrusão do 
Fácies Cratera. Por outro lado, a presença de grande quantidade de flogopita entre os minerais principais sugere tratar-se de um kimberlito pertencente ao Grupo $\|$ da classificação de Smith et al. (1985).

Svisero \& Meyer (1986) analisaram minerais resistatos do kimberlito Batovi 1 pertencentes também a Província de Paranatinga. Segundo esses autores as ilmenitas continham de 8,0 a $13,0 \%$ de $\mathrm{MgO}$, enquanto as granadas por volta de $20,0 \%$ de $\mathrm{MgO}$ e $1,25 \%$ de $\mathrm{Cr}_{2} \mathrm{O}_{3}$. Outro corpo desta província, denominado Batovi-9, foi datado por Davis (1977) o qual obteve uma idade de 121,1 Ma, e também por Heaman et al. (1998) o qual encontrou idade entre 123-126 Ma.

Weska \& Svisero (1997) descreveram uma intrusão localizada a aproximadamente $50 \mathrm{~km}$ de Poxoréu, denominada Tamburi, encaixada em arenitos intensamente silicificados da Formação Aquidauana, fato que ajudou a preservar sua estrutura vulcânica. Segundo os autores citados, esta intrusão tem dimensões de $400 \times 200 \mathrm{~m}$, área de 5,9 ha, destacando-se como um alto topográfico em meio ao cerrado no planalto regional. Possui aspecto brechóide, tendo em sua matriz argilosa um grande número de xenólitos crustais da Formação Aquidauana e do Grupo Cuiabá. Análises químicas de granadas, ilmenitas e espinélios revelaram que esses minerais possuem características complexas exibindo algumas semelhanças com fases kimberlíticas. Uma amostra do corpo foi submetida à digestão ácida revelando a presença um microdiamante no resíduo.

\subsection{Depósitos Diamantíferos}

A prospecção de diamantes pode ser direcionada tanto para fontes primárias representadas por rochas kimberlíticas, como para fontes secundárias abrangendo neste caso uma variedade de sedimentos inconsolidados tais como alúvios, elúvios, colúvios, sedimentos de leito ativo e cascalhos inconsolidados. Rochas desses dois tipos ocorrem na região abrangida por este trabalho, muito embora as atividades de mineração do diamante estejam voltadas exclusivamente para a lavra de materiais inconsolidados. Nas áreas visitadas, da mesma forma que nas demais regiões diamantíferas brasileiras, o diamante é sempre extraído de sedimentos fluviais recentes, não havendo até o presente momento, nenhuma fonte primária em fase de exploração em nosso país. 
As fontes secundárias são muito expressivas no Estado de Mato Grosso. Esses depósitos têm constituído ao longo dos anos um campo fértil para o desenvolvimento de projetos com vista à delimitação de jazidas do tipo pláceres, de que são exemplo as minas do Arranha Céu de Nortelândia, do Rio Coité em Poxoréu, bem como os pláceres da região de Juína (Weska 1996a).

Nos depósitos aluvionares dos Estados de Mato Grosso e Mato Grosso do Sul, as associações minerais mais comuns são de diamante-ouro, diamante-ouro-cassiterita e diamante-safira. Os paleo-pláceres cretácicos constituem as fontes intermediárias entre as áreas fontes primárias pré-cretáceas (Paranatinga, Poxoréu e Juína), as quais entretanto ainda não foram devidamente caracterizadas, e portanto, não está clara a relação desses corpos com os pláceres quaternários diamantíferos da área (Weska 1996b).

A seguir apresentaremos uma descrição sucinta dos depósitos diamantíferos que ocorrem nas áreas amostradas neste trabalho, dos quais provêm as amostras analisadas nesta dissertação.

\subsubsection{Chapada dos Guimarães}

Esta região é constituída geológicamente por uma espessa seqüência sedimentar que registra episódios deposicionais do Paleozóico (Grupo Paraná), Mesozóico (Grupos São Bento e equivalente ao Bauru), Terciário (Formação Cachoeirinha e Fácies Estiva) e Quaternário (Fácies Peba e Água Fria). As unidades Terciárias e Quaternárias comportam os depósitos do tipo pláceres descritos por Weska et al. (1993).

Segundo Weska et al. (1996), os depósitos diamantíferos desta região correspondem às coberturas terciárias e quaternárias que estão situadas na faixa interna e deprimida do alto topográfico da Chapada dos Guimarães; e em porções de meio gráben, sendo resultantes dos processos erosivos referidos à evolução da Bacia Intracratônica do Pantanal.

Weska (1987) e Weska et al. (1996), na tentativa de definir o potencial diamantífero da região consideram que a Fácies Estiva é caracterizada por depósitos de fluxo de lama e detritos grossos, com raros depósitos resultantes do meio transportador mais seletivo. $\mathrm{O}$ ambiente deposicional desta unidade Terciária é de 
leques aluviais, onde o diamante ocorre distribuído erraticamente (heterogêneo), e também concentrado de forma aleatória. Esta fácies é considerada pelos autores citados como a mais promissora para a prospecção do diamante, quando comparada à Formação Cachoeirinha.

Nas unidades Quaternárias Fácies Peba e Água Fria os depósitos coluviais e aluviais são resultantes de um ambiente de deposição fluvial. A Fácies Peba, onde a concentração de seixos de turmalinitos (pretinhas) é maior, apresenta um interesse econômico especial, sendo ainda um guia regional para o diamante na área (Rosa et al. 1993).

Segundo Perin (1993), os eventos de soerguimento da Superfície Geomorfológica Sul Americana iniciaram o desenvolvimento do processo de laterização dos argilitos da Formação Ponta Grossa, atingindo sua maior intensidade no Terciário. Este processo desenvolveu veios e camadas finas de laterita nas fraturas e planos de acamamento dos argilitos desta unidade. Com a retomada do relevo em ciclos fracionados, as lateritas limoníticas foram carreadas para as drenagens da Bacia do Rio Quilombo, sendo depositadas como minerais resistatos juntamente com os produtos de erosão e reconcentração dos conglomerados do Grupo Bauru, à jusante no depósito de cascalho Quilombo-Chiquinho. O garimpo Quilombo-Chiquinho localizado na vila do Peba é caracterizado pela presença de limonitas que ocorrem ao longo do rio Quilombinho, nos depósitos de terraços e colúvios e nos interflúvios e vertentes dos seus tributários Lagoinha e Cachoeira Rica. Este depósito apresenta um pacote de cascalho intercalado ou não com lentes de areia, notadamente de origem fluvial. Os matacões são de arenito e silexito e os seixos são de quartzo, limonita, turmalinito e algumas rochas vulcânicas. A matriz do cascalho varia de areia grossa a areia fina, ocorrendo poucos minerais pesados, destacando-se entre outros, turmalina, topázio, coríndon, crisoberilo, fosfatos, sillimanita, marcassita, zircão e ilmenita. o diamante ocorre de maneira errática nos cascalhos, tanto na vertical (colúvios) como na horizontal (alúvios). Nota-se que há uma tendência de encontrar as pedras maiores nos colúvios, principalmente nas proximidades da área fonte dos cascalhos e conglomerados do equivalente ao Grupo Bauru (Perin 1993).

O equivalente ao Grupo Bauru da região de Poxoréu, como também de Dom Aquino e de Chapada dos Guimarães, é a fonte intermediária para os aluviões recentes destas áreas, sendo as unidades portadoras desta mineralização as Formações Quilombinho (basal) e Cachoeira do Bom jardim (intermediária) (Weska et al. 1993). 
Weska (1987) observou que na região de Chapada dos Guimarães, os depósitos aluviais recentes possuem entre os constituintes fragmentos de turmalinito (pretinha), concreções e nódulos de ferro, magnetita, zircão, ilmenita (pretinha), leucoxênio (faceiras), topázio, pirita, safira (azulinha), coríndon verde? (verdinha), rutilo, anatásio, brookita, turmalina e hematita.

Oliva (1974, In: Barros et al. 1982) cadastrou uma série de ocorrências diamantíferas no Distrito de Água Fria, representadas pelo garimpo Quilombo localizado na Fazenda Buritizinho às margens do rio Quilombo, e o garimpo dos Corvos no córrego Cachoeira. Luz et al. (1980a, In: Barros et al. 1982) cadastraram dois garimpos também no distrito de Água Fria nas proximidades de Buriti e Cachoeira Rica, sendo os aluviões diamantíferos sobrepostos à Formação Bauru. Segundo Rosa et al. (1993), na região de Água Fria foram considerados como fontes importantes de diamante há algum tempo atrás, os aluviões da bacia hidrográfica do Rio Quilombo e seus tributários da margem esquerda representados pelos córregos Água Fria e Estiva, pelo Ribeirão Acorá e Rio Cachoeirinha.

\subsubsection{Poxoréu}

A coluna geológica desta região é constituída da base para o topo pelas Formações Aquidauana (Grupo Itararé), Palermo (Grupo Guatá) e Botucatu (Grupo São Bento), pela Intrusão Tamburi, pelas Formações Paredão Grande, Quilombinho, Cachoeira do Bom Jardim e Cambambe (equivalente ao Grupo Bauru), pela Formação Cachoeirinha, Unidade Terciário/Quaternário Indiviso e Fácies Coité (Aluviões Atuais) (Weska et al. 1996).

As principais feições estruturais desta região são representadas por falhamentos de gravidade de direção $\mathrm{N} 30^{\circ}-60^{\circ} \mathrm{E}$ e mergulho $15^{\circ}$ geralmente para sudeste, de idade cretácica. O Gráben de Poxoréu no qual ocorrem aluviões diamantíferos é balizado por estes falhamentos (Souza 1991).

Weska (1996a) considera que Poxoréu durante o cretáceo, comportou um meio gráben, assim como em Chapada dos Guimarães (Weska 1987), com caimento de superfícies à NW. Associando-se o meio gráben descrito em Paranatinga, com caimento de paleosuperfície à SE, o autor, caracterizou o Rifte Rio das Mortes, onde os limites abrangeriam as regiões entre Poxoréu, Dom Aquino, Chapada dos Guimarães e 
Paranatinga. O rifte seria resultado da atividade da Pluma de Trindade que impactou essa região a 85 Ma (Weska 1996a; Weska et al. 1996 e Gibson et al. 1997). O horste estaria localizado à SE de Poxoréu (Antéclise de Rondonópolis, segundo Coimbra, 1991) e à NW sobre a Faixa Paraguai. Entre outros altos internos, temos como exemplo o da Serra de São Vicente, o da Raizinha (Poxoréu) e o da Passagem do Mamão (Chapada dos Guimarães).

Os depósitos diamantíferos mais expressivos da área estudada estão situados na Bacia do Rio Coité, e estão relacionadas à armadilhas do tipo "travessão". Outros tipos de controles estruturais identificados na área incluem armadilhas do tipo "canoão", veios, bolsões, "ajogo" e panelas (Weska et al. 1996a).

Segundo Weska et al. (1993) foram observadas atividades garimpeiras nos conglomerados da Formação Quilombinho, no garimpo Balaio de Gato desenvolvido sobre conglomerados e cascalhos eluviais, e sobre os conglomerados basais da Formação Cachoeira do Bom Jardim na região da Raizinha.

Os aluviões diamantíferos da região localizam-se preferencialmente ao longo dos rios Coité, São João, Poxoréu, Alcantilados, Pombas e Jácomo. Os depósitos diamantíferos de Poxoréu podem ser classificados em duas categorias: os depósitos recentes que ocorrem nas planícies atuais de inundação dos rios São João, Coité, Poxoréu e outros, e os depósitos de terraços e cascalheiras localizados nas encostas dos vales dos principais rios (Souza 1991).

Segundo Souza (1991), os minerais acompanhantes do diamante nos cascalhos diamantíferos são turmalina (pretinha), rutilo, ilmenita e titanita (ferragem), limonita (feijão) e coríndon (azulinha). Ribeiro \& Maciel (1991) descreveram safiras azuis e verdes, grãos de óxidos de ferro limonitizados (amarelinha mole), turmalinito, óxidos de ferro (feijão vermelho), topázio, leucoxênio, hematita e ouro.

\subsubsection{Alto Paraguai e Diamantino}

A geologia nestas regiões é caracterizada por litologias das Formações Raizama e Diamantino (Grupo Alto Paraguai), sobrepostas pelas Formações Tapirapuã, Grupo Parecis (Formações Salto das Nuvens e Utiariti) Cachoeirinha e Pantanal e Aluviões Atuais da Bacia do Prata ao sul.

As mineralizações diamantíferas estão restritas às coberturas quaternárias 
existentes na porção do Alto Paraguai da Bacia do Pantanal, estando associadas a depósitos aluviais, coluviais e eluviais, considerando-se a distância de transporte em relação à área fonte (Weska et al. 1984).

Alto Paraguai e Diamantino localizam-se na porção leste da Bacia do Alto Paraguai. Nesta bacia ocorrem duas redes maiores de drenagem constituídas pelos rios Santana a noroeste e oeste, e o Paraguai a sudeste e leste. Segundo Barros et al. (1982), a garimpagem ocorre nos principais afluentes do rio Paraguai, a saber: nos rios Santana, São Francisco, Areias dos Bugres e Pari, todos com nascentes na Chapada dos Parecis, à exceção do último, cujas cabeceiras estão na Serra do Tombador, e na bacia do rio Arinos bem como no seu afluente principal, o rio Claro.

Os conglomerados da Formação Utiariti em Mato Grosso são diamantíferos (Petri \& Fúlfaro 1983). Nas regiões de Diamantino, Arenápolis e Alto Paraguai, uma série de ocorrências diamantíferas encontram-se diretamente relacionadas à esta formação, que provavelmente recebeu uma contribuição de diamantes oriundos de fontes primárias do Escudo do Guaporé (Gonzaga e Tompkins 1991).

Segundo Barros et al. (1982), uma das fontes dos diamantes que ocorrem nos pláceres das regiões do Alto Paraguai e Diamantino, são as camadas conglomeráticas que ocorrem intercaladas na Formação Utiariti. Carvalho et al. (1991) considera que os sedimentos da Formação Utiariti seriam a possível fonte para os diamantes que ocorrem na Fazenda Camargo próximo a Diamantino. Este fato torna esta unidade uma das prováveis fontes dispersoras do diamante na região, uma vez que as nascentes dos rios Paraguai e Arinos (ambos diamantíferos) estão situadas nesta formação. Segundo Barbosa (1991), os conglomerados da Formação Utiariti são lavrados pelos garimpeiros de diamantes na região de Nortelândia.

Segundo Takanohashi (1974, In: Barros et al. 1982) ocorrem atividades garimpeiras aurodiamantíferas no município de Diamantino concentradas sobretudo ao longo dos terraços aluviais do córrego Diamantino, do rio Claro, e nas imediações dos rios Sumidouro Grande e Água Verde (Figura 1.2).

Nas regiões garimpeiras de Alto Paraguai, Diamantino, Nortelândia, Arenápolis, Nova Marilândia e Santo Afonso, agrupadas por Silva et al. (1997) como uma sub-bacia do Alto Paraguai, as atividades mineradoras desenvolvidas no decorrer dos anos envolveram garimpagem manual (garimpos de monchão, rêgo d'água e grupiara) e mecanizada (garimpos de dragas e de balsas) dos aluviões diamantíferos que se localizam nos rios Diamantino, Pari, Córrego do Gatinho, Rio Paraguaizinho, Santana e 
seus afluentes. Segundo os mesmos autores, foram cadastradas entre junho e setembro de 1996, 125 dragas, 7 balsas e 1.645 trabalhadores envolvidos diretamente nas atividades mineradoras.

\subsubsection{Paranatinga}

No município de Paranatinga a geologia é representada pela Faixa de Dobramentos Paraguai (rochas do Grupo Cuiabá e Alto Paraguai); na porção sul pelos sedimentos paleozóicos e mesozóicos da Bacia Intracratônica do Paraná; e ao norte pelos sedimentos da Formação Utiariti (Grupo Parecis) posicionados geograficamente sobre a porção sul do Cráton Amazônico (Gonzaga \& Tompkins 1991).

A garimpagem nesta região teve inicio nos leitos, terraços aluvionares e nos cascalhos que jazem ao longo das drenagens dos Rios Batovi e Jatobá. Os diamantes desta região têm como fonte dispersora, segundo Barros et al. (1982), as rochas do Grupo Parecis.

$\mathrm{Na}$ região de Paranatinga, os rios Batovi, Jatobá e Piranhas, que são diamantíferos, tem nascentes e correm sobre sedimentos da Formação Utiariti também diamantífera segundo Petri \& Fúlfaro (1981, In: Barros et al. 1982), assim como possuem inúmeras intrusões kimberlíticas em suas cabeceiras, de que são exemplos as intrusões Piranhas I e II, (Filemon et al. 1997), e o K3, (Weska et al. 1993) no rio Jatobá.

As intrusões anteriormente colocadas foram englobadas pela Província Kimberlítica de Paranatinga (Fragomeni 1976), que segundo Barros et al.(1982), Gonzaga \& Tompkins (1991), provavelmente sejam as fontes primárias do diamante da região. Entretanto, até o presente momento não existem evidências relacionando estes depósitos diamantíferos aluvionares com as intrusões kimberlíticas da região.

Sendo o diamante um mineral pesado, cujas características físicas e químicas Ihe conferem extrema resistência e estabilidade durante o transporte, ele pode ser retrabalhado a partir de suas fontes através de sucessivos ciclos deposicionais (Campos \& Gonzaga 1999). Considerando também os ambientes deposicionais, onde são encontrados os depósitos diamantíferos, tais como os sistemas fluviais de leques aluviais, de rios entrelaçados, de rios meandrantes, depósitos de interação entre esses sistemas, bem como ambientes fluvio-glaciais e canais subglaciais (zona basal de 
geleiras), é extremamente complexo o entendimento da distribuição do diamante nos pláceres atuais, a partir de suas áreas-fonte.

As ocorrências diamantíferas estudadas nesta dissertação estão distribuidas em regiões relativamente afastadas entre si. Conseqüentemente, é possivel que esses diamantes estejam relacionados a várias áreas-fonte, sejam elas primárias e/ou secundárias. Portanto, com base no exposto neste capítulo, as fontes dos diamantes que ocorrem nas regiões de Diamantino e Alto Paraguai podem ser os sedimentos das formações Salto das Nuvens e Utiariti (Grupo Parecis), ou ainda fontes primárias não identificadas. Na região de Paranatinga, a origem do diamante pode estar relacionada tanto à Formação Parecis como também à rochas kimberlíticas (no sentido de Haggerty 1999) da Província Kimberlítica de Paranatinga. Em Chapada dos Guimarães, as fontes podem estar relacionadas aos sedimentos do equivalente ao Grupo Bauru da região (Weska 1996a). Finalmente, na região de Poxoréu as fontes podem estar relacionadas ao equivalente do Grupo Bauru (Weska op cit.), ou ainda à fontes primárias desconhecidas. 


\section{GRANULOMETRIA}

A granulação é uma das propriedades físicas fundamentais das substâncias minerais naturais ou artificiais, uma vez que permite expressar quantitativamente a distribuição de populações de grãos em função do tamanho e do peso. Através da análise granulométrica é possível determinar as classes distintas e a porcentagem de indivíduos granulares, estabelecendo desta forma curvas padrões para cada tipo de material (Pettijohn 1957).

A análise granulométrica fornece, em primeiro lugar, a distribuição de freqüência da granulometria, ou seja, descreve como as unidades de uma população estão distribuídas em intervalos de valores possíveis. Posteriormente, esses dados são convertidos em informações numéricas e gráficas que são um resumo da descrição das amostras. Os resultados obtidos destacam as variações das características do material em estudo e, podem ser utilizados para fazer comparações entre amostras de procedências diferentes.

A esfericidade e a forma geométrica dos grãos têm um efeito decisivo na granulometria determinada, pois influenciam na eficiência da separação (peneiramento) $e$, conseqüentemente na distribuição da granulometria. Quando os grãos possuem os três eixos de comprimento iguais $(a=b=c)$, a separação depende somente do diâmetro das partículas. Se os grãos são caracterizados por um eixo maior (c) e dois eixos menores iguais, perpendiculares entre si $(a=b \neq c)$, depende somente dos eixos menores. No caso dos grãos possuírem os três eixos perpendiculares entre si com comprimentos desiguais $(a \neq b \neq c)$, o diâmetro que permite a passagem pelas peneiras é o médio (Schneiderhohn 1953, In: Muller 1967).

\subsection{Representação gráfica}

A distribuição de freqüências é mais fácil de ser visualizada quando representada graficamente. Alguns dos gráficos mais utilizados para ilustrar esta distribuição são o diagrama de barras e o histograma, que além da rapidez e facilidade de compreensão, destacam visualmente diferenças e/ou similaridades entre as amostras analisadas. Nestes tipos de gráficos pode ser observada, pela extensão do espalhamento (número de classes granulométricas), a variação granulométrica e, 
portanto o grau de seleção das amostras. Além disso, pode ser observada também a classe modal e o tipo de simetria das classes granulométricas.

A curva de freqüência simples equivale à curva de contorno suave desenhada sobre o histograma. Essa curva permite observar rapidamente o número de modas em um diagrama, que pode ser unimodal (uma freqüência máxima) ou polimodal (várias freqüências máximas).

O gráfico de freqüência acumulada fornece, assim como os outros gráficos, uma boa visualização da distribuição granulométrica. Cada intervalo de classe em abcissa corresponde em ordenada à soma das freqüências dos intervalos de classe até o intervalo considerado, ou seja, as freqüências dos dados agrupados nos intervalos são agora acumuladas.

Neste trabalho foi usado rotineiramente o diagrama de barra para demonstrar graficamente a distribuição dos dados obtidos. Já o histograma foi empregado para demostrar os resultados da análise estatística.

\subsection{Representação numérica}

Embora a representação gráfica conduza a uma quantidade de informações concernentes à distribuição do conjunto de medidas de uma amostra, informações da distribuição podem ser obtidas também através da descrição numérica, ou seja, através de parâmetros estatísticos. Tais parâmetros permitem estudar as propriedades da população em torno do valor médio medido. Dessa forma, usou-se como medidas de tendência central a média, a mediana e a moda. Como medidas de grau de dispersão dos dados em torno da média utilizou-se a variância, o desvio padrão, o coeficiente de variação e a assimetria. Essas medidas são descritas pelas expressões analíticas mostradas a seguir.

A média $(m)$ é calculada pela soma dos valores de todas as observações $\left(x_{i}\right)$ dividida pelo número de observações (n), ou seja:

$$
m=1 / n \sum_{i=1}^{n} x_{i}
$$

onde $m=$ média; $\sum \mathrm{x}_{\mathrm{i}}=$ somatória dos valores encontrados nos intervalos de classes; e $\mathrm{n}=$ número de amostras.

A média caracteriza a granulometria mais provável, indicando a ordem de 
magnitude do tamanho dos grãos. As variações granulométricas de diamantes de áreas diferentes podem ser comparadas entre si com base nas médias obtidas. Contudo, o valor médio representa o valor central provável e não indica nada sobre o espalhamento dos dados em ambos os lados desse ponto. Por isso, tornam-se necessárias medidas do grau de dispersão em torno da média.

A variância mede a dispersão dos valores em torno da média sendo calculada pela fórmula:

$$
S^{2}=1 / n \sum_{i=1}^{n}\left(x_{i}-m\right)^{2}
$$

A variância é um número em unidades quadradas. Dessa forma, se $x_{i}$ representa, por exemplo, o peso em quilate, a variância $\left(S^{2}\right)$ é dada em quilate ao quadrado. Porém, é desejável que as quantidades que descrevem a distribuição possuam as mesmas unidades que o conjunto original de medidas. A média satisfaz este requisito, mas a variância não. No entanto, extraindo-se a raiz quadrada da variância, o efeito desejado é obtido e a quantidade resultante (S) é chamada de desvio-padrão da distribuição (Hoel 1963).

Portanto, o desvio padrão (S) reflete também a tendência dos grãos em se distribuírem em torno do valor médio, sendo expresso na mesma unidade dos valores originais, ou seja,

$$
S=\sqrt{S^{2}}
$$

O coeficiente de variação (CV), que é outra medida de dispersão, é obtido pela divisão do desvio padrão pela média. Por ser adimensional, é utilizado freqüentemente para comparar a dispersão relativa dos valores em torno da média entre diferentes distribuições. Essa medida é expressa pela fórmula:

$$
\mathrm{CV}=\mathrm{S} / \mathrm{m}
$$

A assimetria determina o quanto a moda se desloca em relação a média. A assimetria pode ser negativa quando a distribuição é alongada à esquerda e positiva quando alongada à direita. 


\subsection{Estudos anteriores}

Nos últimos anos surgiram diversos trabalhos na literatura enfocando a classificação granulométrica de diamantes de fontes primárias e secundárias. $O$ objetivo fundamental desses trabalhos era caracterizar populações de depósitos e/ou áreas distintas, correlacionar os resultados entre si e tentar dessa forma obter padrões distintos ou não para cada alvo analisado. Nesse sentido, Whitelock (1973) caracterizou 5.000 diamantes do Complexo Kimberlítico Kao, situado em Lesotho. Neste trabalho, o autor apresenta dados referentes a 2.700 cristais provenientes do ponto Quarry, bem como outros 2.300 diamantes correspondentes a 16 outros pontos amostrados no referido complexo. O intervalo de distribuição granulométrica foi dividido em nove frações de tamanho, situados entre 2,5 e $8 \mathrm{~mm}$ (Figura 4.1).

Os dados referentes ao Complexo Kao mostram que a análise granulométrica realizada nos dezessete pontos apresenta uma distribuição unimodal, conforme está ilustrado na Figura 4.1. Em adição, em dezesseis pontos a moda situa-se na fração 2,84 mm e, em um único ponto na fração 2,47 (6S.21E).

Ainda segundo Whitelock (1973), diamantes provenientes de um único kimberlito exibem uma variedade de características físicas como a forma, o tamanho, estruturas de superfície das faces, inclusões e cores. Portanto, se um número suficiente de amostras forem analisadas, torna-se aparente que a freqüência de algumas destas características são distintivas deste kimberlito.

Harris et al. (1975) apresentaram dados relativos às propriedades físicas de diamantes dos Kimberlitos Premier, Finsch e Koffyfontein, baseando-se em lotes de $24.400,29.900$ e 10.000 cristais, respectivamente. Nesse trabalho, há também dados referentes a um lote de 3.600 diamantes provenientes do depósito aluvionar Dreyers Pan. A metodologia aplicada por esses autores não considerou a distribuição granulométrica, mas um número fixo de cristais de $100 \mathrm{em}$ cada intervalo granulométrico. Este método difere da proposta utilizada no presente trabalho que analisa a granulometria e a distribuição de freqüência do peso e o número de cristais presentes em cada lote. Desta forma não foi possível correlacionar os diamantes estudados nessa dissertação com os dados apresentados pelo referido autor.

No entanto, Harris et al. (1975) demonstraram que as características físicas do diamante para uma fonte em particular, variam com o tamanho dos cristais. Para fazer 


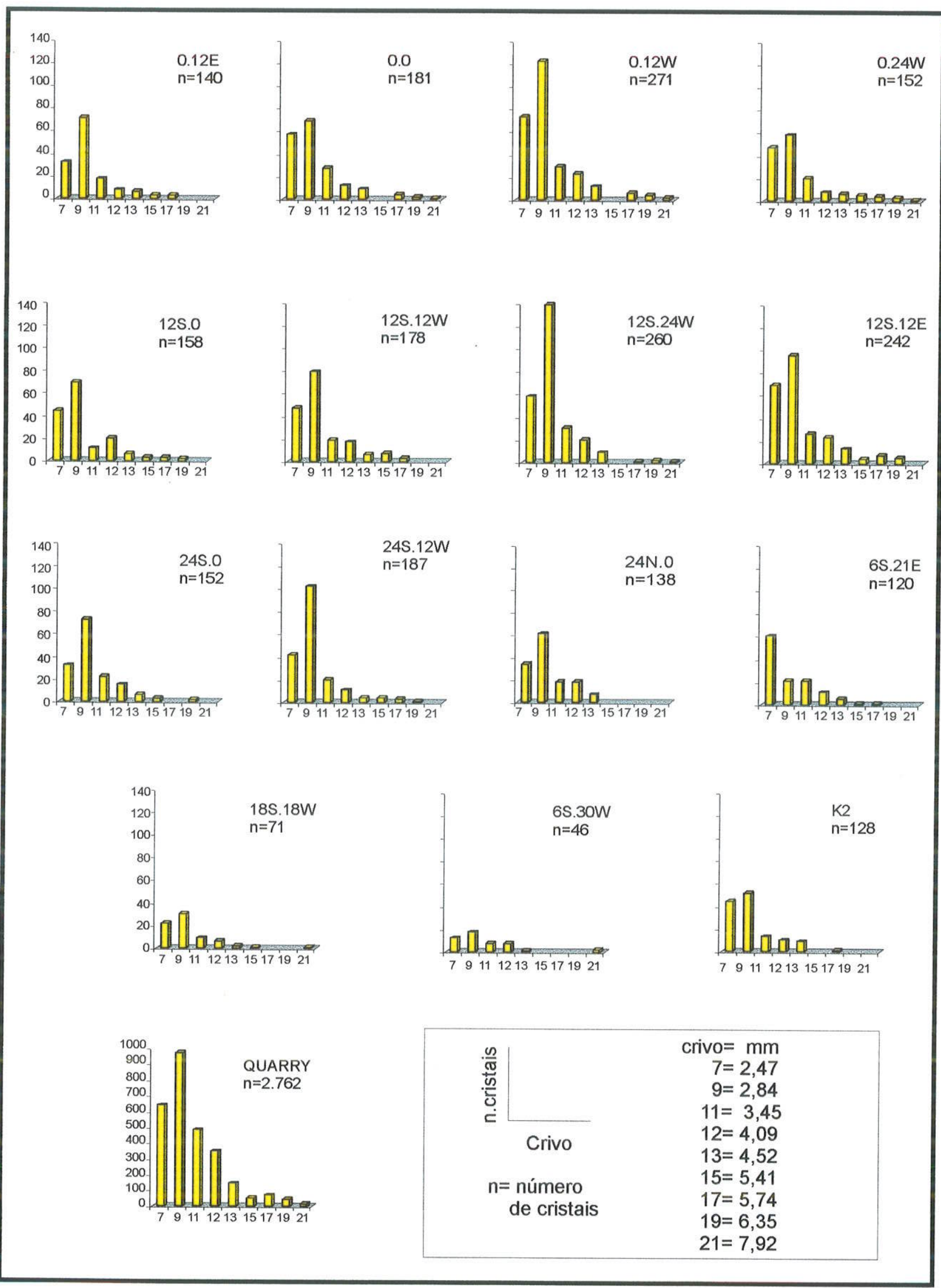

Figura 4.1 - Distribuição da granulometria do diamante no Complexo Kimberlítico Kao, Lesotho. Exceto em um único ponto amostrado (6S.21E), observa-se o predomínio da fração 9. Modificado de Whitelock (1973). 
essas considerações sobre as propriedades físicas em função do tamanho, os referidos autores analisaram estas propriedades associando-as ao espalhamento granulométrico total.

Em trabalho subseqüente, Harris et al. (1979) deram continuidade aos estudos dos Kimberlitos Premier, Finsch e Koffyfontein, acrescentando dados sobre os Kimberlitos Zwartruggens e Ebenhaezer da África do Sul e, Letseng Le Terai no Lesotho. Neste trabalho aplicaram a sistemática de Harris et al. (1975) para variações verticais (profundidade da intrusão), fixando novamente o número de cristais em 100 por crivo utilizado. Portanto, as considerações feitas neste trabalho envolveram as características da morfologia e da cor em função da granulometria dos cristais, e não a variação granulométrica e seu significado.

McCallum et al. (1979) caracterizaram a mineralogia de diamantes provenientes de kimberlitos da Província Colorado-Wyoming situada nos Estados Unidos da América. Esses autores analisaram um lote pequeno constituído de 78 cristais, com peso de 0,42 ct, no qual predominou a fração entre 0,3 a $1,0 \mathrm{~mm}$. Os autores observaram que o número de amostras era insuficiente para um tratamento estatístico confiável e enfatizaram também que os trends obtidos, principalmente para a distribuição das pedras maiores, tinham caráter apenas qualitativo. Ressaltaram também que o objetivo principal do trabalho era registrar a ocorrência de diamantes nos referidos locais, bem como indicar a tendência geral das propriedades físicas exibidas pelos diamantes (Figura 4.2).

Otter et al. (1994) analisaram diamantes do Complexo Kimberlítico Sloam 1 e 2, da província Colorado-Wyoming, Estados Unidos da América. Esses autores consideram que devido à dissolução e/ou fraturamento, o diamante perde parte do seu tamanho natural (tamanho primário). Segundo esses autores, a distribuição do tamanho obtida por peneiramento reflete o tamanho secundário, após a reabsorção dos cristais. Neste trabalho, estudaram uma população de 14.723 amostras na qual a distribuição destes cristais situou-se entre os intervalos granulométricos $<1,3 \mathrm{~mm}, 1,3$ $2,3 \mathrm{~mm}$ e $>2,3 \mathrm{~mm}$, correspondendo aproximadamente a $<0,02 \mathrm{ct}, 0,02-0,07$ ct e 0,07 ct. A distribuição nesse caso também é unimodal com a moda situando-se no intervalo $<1,3 \mathrm{~mm}$ ou $<0,02$ quilates (Figura 4.3).

O tamanho relativamente pequeno dos diamantes que ocorrem em Sloan 1 \& 2 reflete as condições do ambiente de cristalização, podendo estar relacionado à razão de crescimento, à duração do evento de cristalização e/ou simplesmente à 


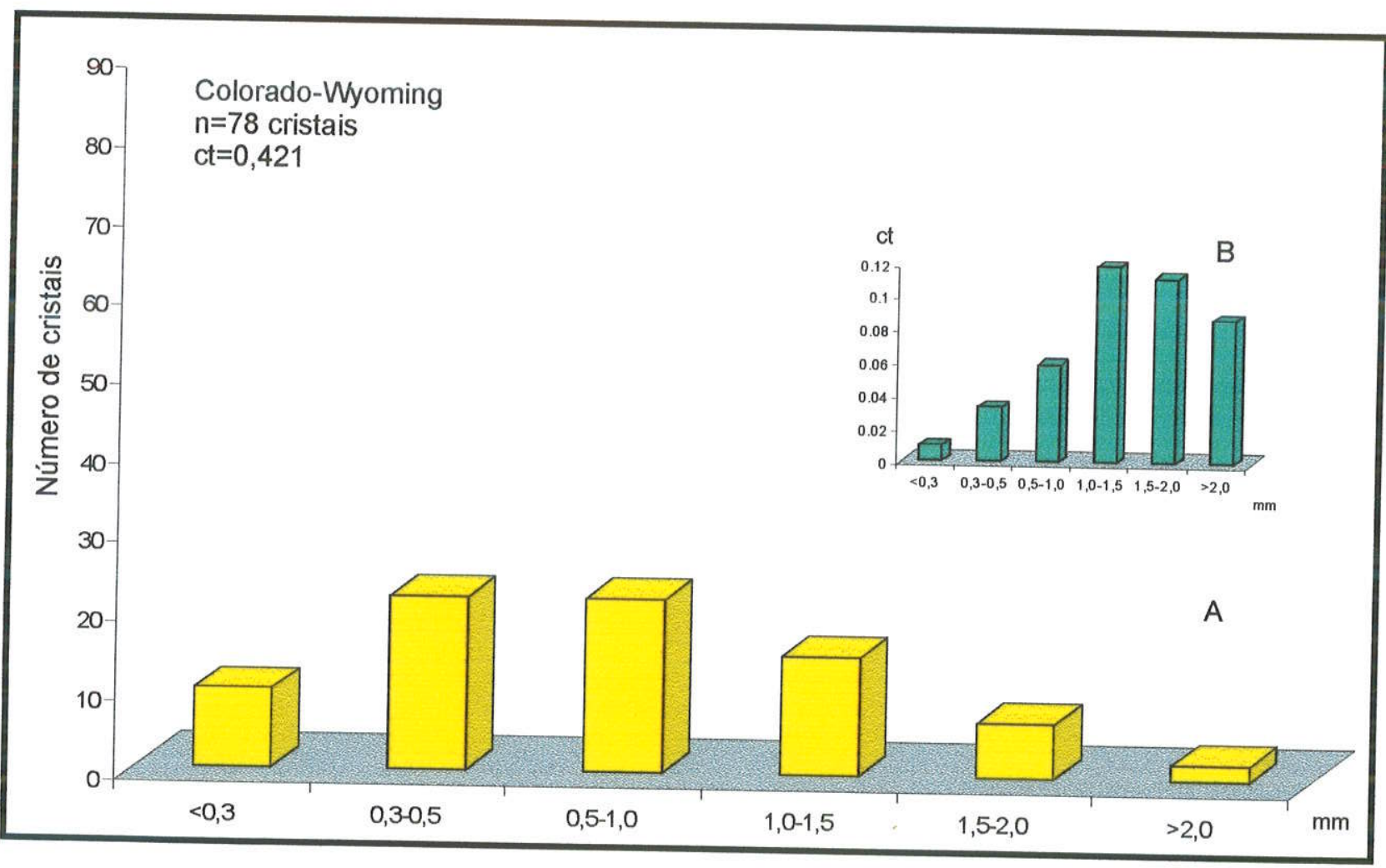

Figura 4.2 - Distribuição da granulometria em função do número de cristais $(A)$ e do peso (B); de diamantes dos diatremas (Sloan 1 e 2), Schaffer 3, 10, 13, 15, 16 e 19, Autman e Nix. Dados extraídos de McCallum et al.(1979).

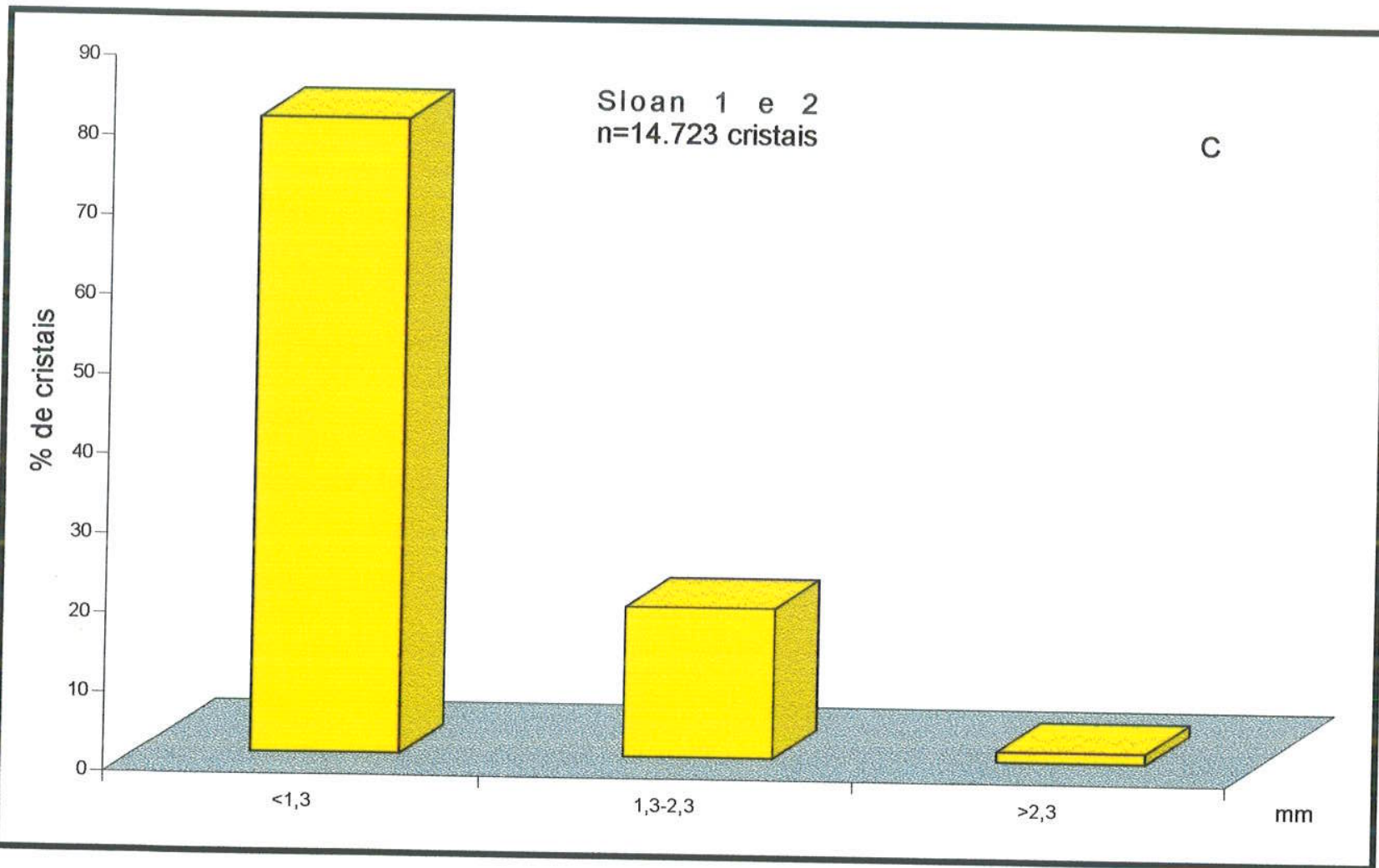

Figura 4.3 - Distribuição da granulometria em função da porcentagem de diamantes dos diatremas Sloan 1 e 2. Dados extraídos de Otter et al. (1994). 
disponibilidade de carbono nos diferentes ambientes de crescimento do diamante. 0 tamanho pequeno dos cristais sugere também que a reabsorção foi forte ou de duração suficiente para reabsorver considerável quantidade de material.

Os primeiros estudos sobre a caracterização de diamantes brasileiros são devidos a autores que descreveram pedras isoladas e famosas de grande quilatagem. As primeiras descrições de megadiamantes (pedras acima de 50 ct) foram apresentadas por Derby (1911), Barbosa (1938), Leonardos \& Saldanha (1939), Saldanha (1941, 1942), Svisero \& Haralyi (1978), entre outros. Leinz (1939) descreveu - Getúlio Vargas, de 627 ct, que continua sendo o maior diamante encontrado até hoje no Brasil. Esses trabalhos não tinham por objetivo efetuar caracterizações granulométricas, mas unicamente registrar a ocorrência desses megadiamantes. Reis (1959) apresenta uma discussão pormenorizada das características mineralógicas dos grandes diamantes registrados oficialmente. Merece destaque o fato da maior parte dos megadiamantes brasileiros terem sido encontrados na região oeste de Minas Gerais. Pedras desse porte são desconhecidas nas regiões garimpeiras amostradas no decorrer desse trabalho.

Leite (1969) apresentou dados relativos à distribuição em peso de um lote constituído por 230 pedras do tipo indústria proveniente de garimpos distribuidos na região oeste de Minas Gerais. O peso desses cristais variou entre 0,2 a 2,00 ct (Figura 4.4). Neste caso a distribuição da freqüência granulométrica é unimodal em $0,2 \mathrm{ct}$, refletindo o predomínio de cristais pequenos.

Svisero et al. (1981) analisaram um lote de 5.317 cristais de diamantes, pesando 450,3 quilates, procedentes da Mina de Romaria, antiga Água Suja, Minas Gerais. Conforme se pode observar pela Figura 4.4 o espalhamento granulométrico cobre o intervalo 1,0 a $11,3 \mathrm{~mm}$, estando a moda situada no intervalo 2,0-2,8 mm. O peso predominante do lote situa-se na fração 1,4 a 2,0 mm. A queda brusca na fração < 1,4 $\mathrm{mm}$, segundo os autores, é provocada pela abertura utilizada no trommel durante a recuperação (Figura 4.4).

Haralyi \& Svisero (1986) fizeram uma análise dos diamantes produzidos na Mina de Boa Vista, na região de Diamantina, Minas Gerais. Ao todo, foram considerados 3.832 diamantes totalizando 501,63 quilates e verificada uma mediana da ordem de $0,26 \mathrm{ct}$, através dos livros de controle diário da produção cobrindo o período de 27-121963 a 22-01-1965.

Chieregati (1989) analisou diamantes das regiões de Itararé, Jaguariaíva, 


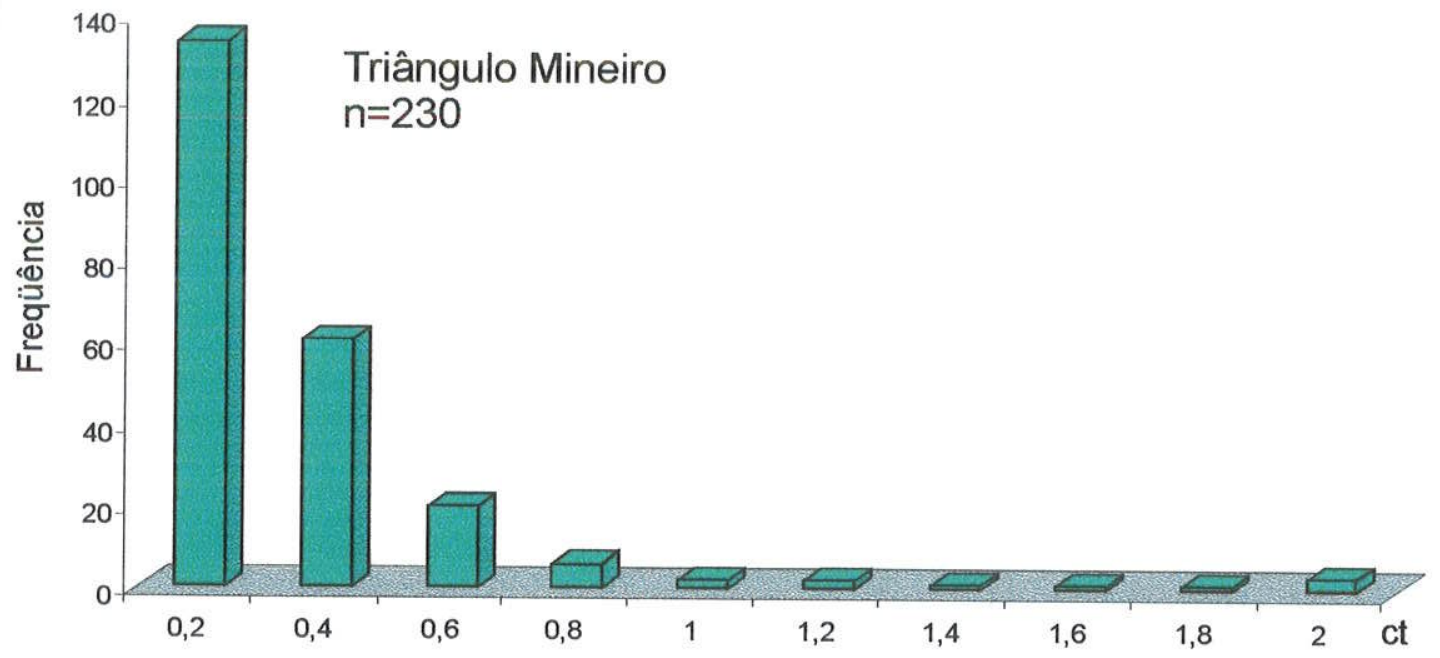

(A)
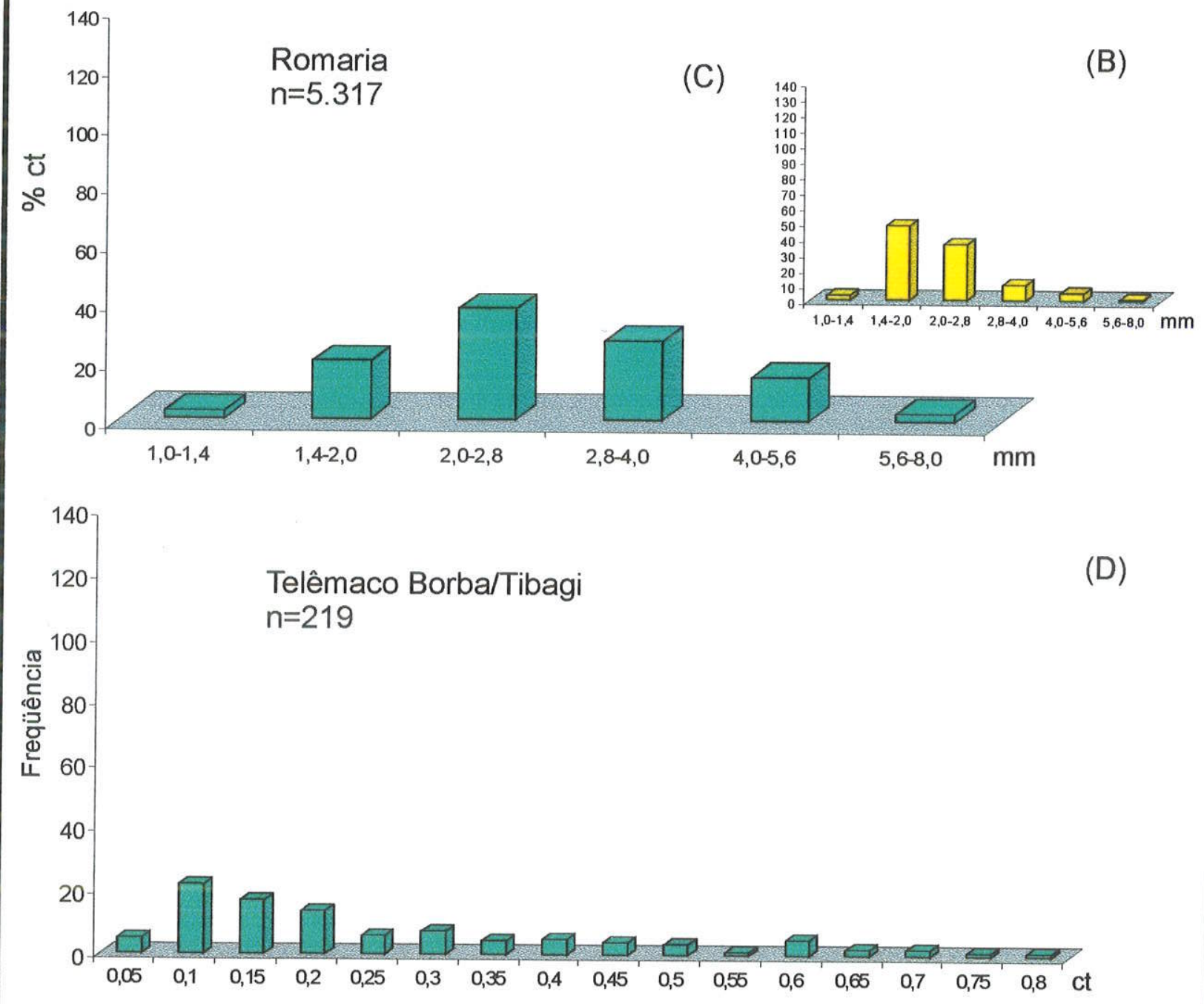

Figura 4.4 - (A) Distribuição do peso em quilates em função do número de amostras de diamantes da região do Triângulo Mineiro, MG (Leite 1969); (B) granulometria (mm), em função da porcentagem do peso em quilates e (C) granulometria em $\mathrm{mm}$ em função da porcentagem do número de diamantes de Romaria, MG (Svisero et al. 1981); (D) distribuição do peso em função da freqüência de diamantes provenientes de Telêmaco Borba/ Tibagi, PR (Chieregati 1989). 
Tomazina, Ibaiti, Telêmaco Borba e Tibagi, totalizando 219 cristais que foram pesados individualmente. A distribuição de peso obtida na região de Telêmaco Borba situou-se no intervalo de 0,10 a 0,15 quilates (Figura 4.4). Esse autor relacionou a possibilidade de algumas pedras de qualidade gemológica superior terem sido retiradas dos lotes antes das análises.

Chaves (1997) caracterizou a distribuição em peso de diamantes provenientes de três regiões distintas da Serra do Espinhaço, Minas Gerais. No Distrito de Diamantina, nas áreas diamantíferas do Rio Jequitinhonha analisou 1254 cristais cujo peso predominante situou-se entre 0,21 e 0,40 ct. Na região de Datas, o referido autor estudou um lote composto por 597 cristais com o peso predominando entre 0,01 e 0,20 ct. Finalmente, no Distrito de Grão Mogol, analisou um lote constituído de 768 cristais cuja classe modal situou-se entre 0,01 e 0,20 ct, enquanto no Distrito da Serra do Cabral (área de Jequitaí) foi analisado um lote constituído de 408 cristais, no qual o peso predominante ficou entre 0,01 e 0,20 ct. Os dados mostraram que a distribuição de freqüência do peso observada é polimodal na região do Rio Jequitinhonha e unimodal nas áreas restantes, com predomínio do intervalo 0,2 a 0,4 ct (Figura 4.5).

Andrade (1999) analisou um lote de 180 cristais da Chapada Diamantina, Bahia, de distribuição polimodal no qual predominou a fração granulométrica $1,7 \mathrm{~mm}$. O lote analisado pertence a um colecionador, sendo constituído por pedras escolhidas, não refletindo desta forma um registro estatístico da região.

Encontra-se em estudo (Svisero \& Zolinger em preparação) um lote de diamantes do tipo indústria proveniente da Serra da Canastra, Minas Gerais, constituído por 390 cristais, pesando 72,15 quilates. Neste lote predominaram cristais nas frações menores de $1,7 \mathrm{~mm}$, representando a classe modal dos diamantes analisados (Figura 4.5).

\subsection{Granulometria dos diamantes estudados}

Nesta dissertação foram estudados lotes distintos de diamantes detríticos das regiões de Poxoréu, Chapada dos Guimarães, Paranatinga, Alto Paraguai e Diamantino, constituídos respectivamente de 1.466, 233, 1.191, 1.040 e 268 cristais.

Apesar do número de diamantes recuperados durante todo o período em que os depósitos foram explorados ser desconhecido, as amostras analisadas revelaram 
características granulométricas e de peso, as quais comparadas entre si mostram também a tendência regional.

Os lotes foram classificados segundo a bateria de crivos (peneiras) utilizadas no comércio de diamante bruto (Padrão ANTWERP). Os cristais de cada intervalo granulométrico foram pesados em conjunto, devido ao fato da maior parte das amostras possuir diâmetro reduzido, inviabilizando a pesagem individual. Na Tabela 4.1 estão apresentadas as séries de peneiras utilizadas, as constantes referentes ao diâmetro do crivo e o número de pedras por abertura. Essas informações foram extraídas do Boletim de Preços editado pelo Departamento Nacional de Produção Mineral até 1991.

A grande amplitude de variação da granulometria do diamante abrange desde microdiamante $(\leq 1 \mathrm{~mm})$ a macrocristais $(>1 \mathrm{~mm})$. Por conveniência, neste trabalho estabeleceu-se o intervalo granulométrico entre o crivo $6(1,70 \mathrm{~mm})$ a $19(3,7 \mathrm{~mm})$, onde a fração mais fina considerada foi $<1,70 \mathrm{~mm}$ (crivo 6) e, a mais grossa $>3,7 \mathrm{~mm}$ (crivo 19).

Em relação ao peso do diamante bruto ou lapidado, utilizou-se o quilate métrico (ct), dividido em 100 unidades menores (pontos), de tal modo que $0,2 \mathrm{~g}=1 \mathrm{ct}=100$ pontos. Nos gráficos a distribuição é expressa em peso ou em número de cristais, versus os intervalos granulométricos utilizados.

A distribuição granulométrica (número de cristais), observada nos diamantes das regiões estudadas é variada (Tabela $4.2 \mathrm{~A}$ e B). Os lotes provenientes de Paranatinga e Poxoréu, constituídos por 1.191 e 651 cristais, respectivamente, são unimodais, predominando os intervalos $1,7-2,9 \mathrm{~mm}$, conforme Figura 4.6. O comportamento unimodal observado é devido provavelmente ao fato do intervalo granulométrico (espalhamento) considerado ser extenso, ocultando desta forma variações. Os demais lotes de Poxoréu, bem como os das outras regiões amostradas foram analisados com intervalos granulométricos menores, obtendo-se uma distribuição granulométrica polimodal, tal como está mostrado nas Figuras 4.7 e 4.8. Em Paranatinga não foi possível obter dados novos devido ao fato de não termos tido acesso a outros lotes.

A distribuição do peso por intervalo granulométrico foi efetuada em lotes provenientes de todas as áreas amostradas, com exceção dos lotes $\mathrm{Pa}(1)$ e $\mathrm{Px}(3)$, conforme está apresentado na Tabela 4.2 B. A distribuição do peso nos demais lotes amostrados, em função da granulométrica é polimodal conforme está mostrado nas Figuras 4.9 e 4.10. Confrontando os dois tipos de gráficos de distribuiçöes (freqüência 

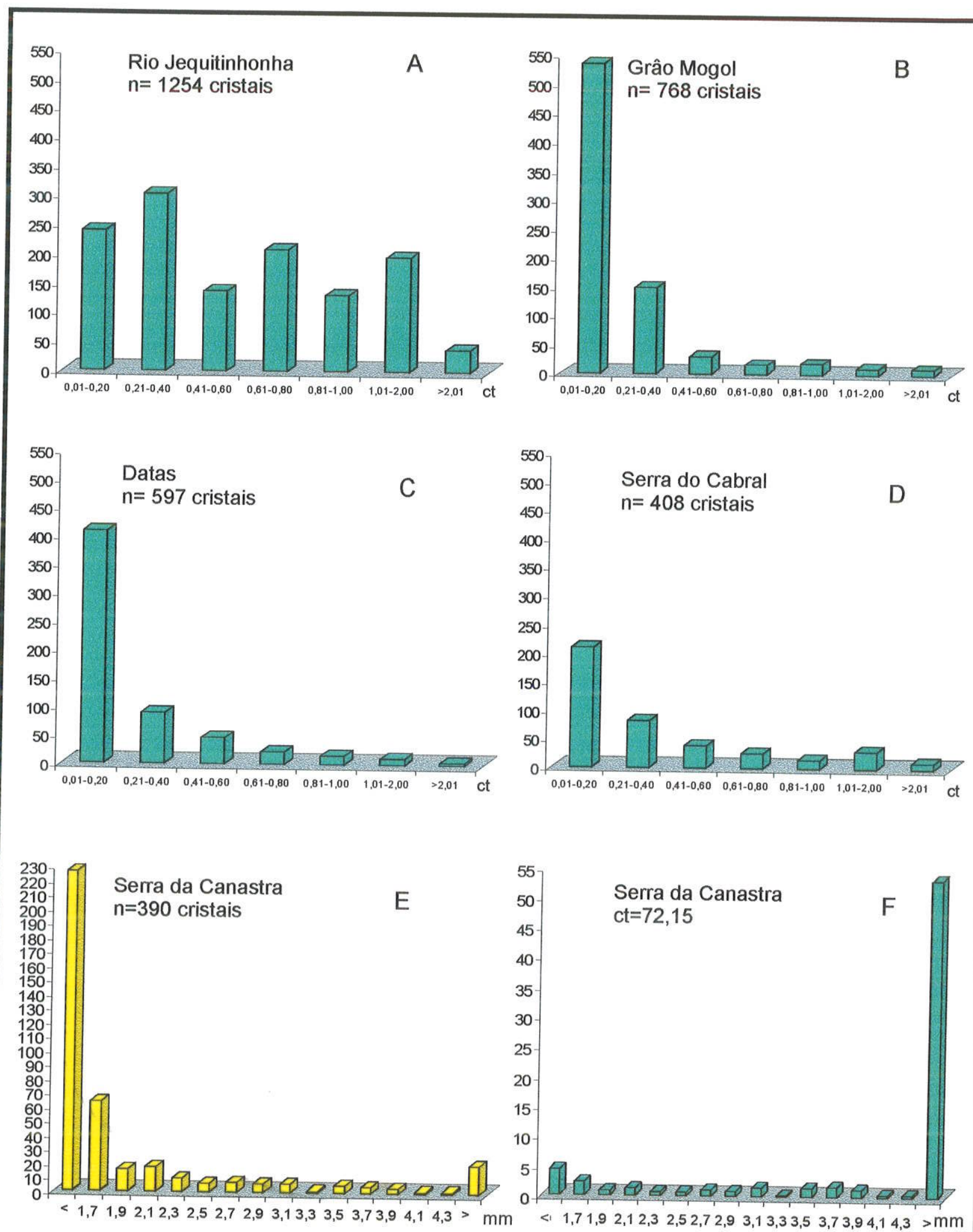

Figura 4.5 - Distribuição do peso em função do número de cristais na área do Rio Jequitinhonha (A); no Distrito de Grão Mogol (B); em Datas (C) e, na área de Jequitaí (D), pertencentes ao Distrito de Diamantina, localizado na Serra do Espinhaço, MG. Extraído de Chaves (1997). Em E e F estão as distribuições da granulometria e do peso em função do intervalo granulométrico (crivo) de diamantes da Serra da Canastra (Svisero \& Zolinger, em preparação). 
Tabela 4.1 - Constantes dos crivos usados na classificação granulométrica do diamante pelo sistema "ANTWERP". Modificado do Boletim de Preços do DNPM (1991).

\begin{tabular}{|c|c|c|c|c|c|}
\hline $\begin{array}{l}\text { Número } \\
\text { do crivo }\end{array}$ & {$\left[\begin{array}{lll}N^{\circ} & \text { aproximado } \\
\text { de } & \text { pedras } & \text { por } \\
\text { quilate } & \end{array}\right.$} & $\begin{array}{ll}\text { Diâmetro } \\
\text { do } & \text { crivo } \\
(\mathrm{mm}) & \end{array}$ & $\begin{array}{l}\text { Número } \\
\text { do crivo }\end{array}$ & $\begin{array}{lll}N^{\circ} . & \text { aproximado } \\
\text { de } & \text { pedras } & \text { por } \\
\text { quilate }\end{array}$ & 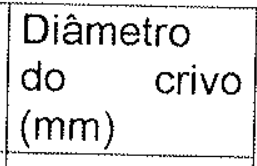 \\
\hline 0 & 200 & 1,10 & 10,5 & 17 & 2,60 \\
\hline 1 & 175 & 1,15 & 11 & 16 & 2,70 \\
\hline 1,5 & 150 & 1,20 & 11,5 & 15 & 2,80 \\
\hline 2 & 125 & 1,25 & 12 & $12 / 13$ & 2,90 \\
\hline 2,5 & $110 / 115$ & 1,30 & 12,5 & 11 & 3,00 \\
\hline 3 & $91 / 100$ & 1,35 & 13 & $9 / 10$ & 3,10 \\
\hline 3,5 & $81 / 90$ & 1,40 & 13,5 & 8,5 & 3,20 \\
\hline 4 & $71 / 80$ & 1,45 & 14 & 8 & 3,30 \\
\hline 4,5 & $61 / 70$ & 1,50 & 14,5 & $7 / 7,5$ & 3,40 \\
\hline 5 & $51 / 60$ & 1,55 & 15 & 6,5 & 3,50 \\
\hline 5,5 & $49 / 50$ & 1,60 & 15,5 & 6 & 3,60 \\
\hline 6 & $46 / 48$ & 1,70 & 16 & 5,5 & 3,70 \\
\hline 6,5 & $36 / 45$ & 1,80 & 16,5 & $5 / 5,25$ & 3,80 \\
\hline 7 & $34 / 35$ & 1,90 & 17 & 4,75 & 3,90 \\
\hline 7,5 & $31 / 33$ & 2,00 & 17,5 & 4,5 & 4,00 \\
\hline 8 & $26 / 30$ & 2,10 & 18 & 4,25 & 4,10 \\
\hline 8,5 & $23 / 25$ & 2,20 & 18,5 & 4 & 4,20 \\
\hline 9 & $21 / 22$ & 2,30 & 19 & 3,7 & 4,30 \\
\hline 9,5 & $19 / 20$ & 2,40 & 19,5 & 3,33 & 4,40 \\
\hline 10 & 18 & 2,50 & 20 & $1 / 3$ & 4,50 \\
\hline
\end{tabular}




\begin{tabular}{|c|c|c|c|c|c|c|c|c|c|c|c|c|c|c|c|c|c|c|c|c|}
\hline Local & \multicolumn{2}{|c|}{$C G(1)$} & \multicolumn{2}{|c|}{ CG (2) } & \multicolumn{2}{|c|}{ CG (3) } & \multicolumn{2}{|c|}{$P \times(1)$} & \multicolumn{2}{|c|}{$P \times(2)$} & \multicolumn{2}{|c|}{$\mathrm{Di}(1)$} & \multicolumn{2}{|c|}{ AP (1) } & \multicolumn{2}{|c|}{$\mathrm{AP}(2)$} & \multicolumn{2}{|c|}{$\mathrm{AP}(3)$} & \multicolumn{2}{|c|}{$\mathrm{AP}(4)$} \\
\hline $\begin{array}{c}\text { Crivo } \\
\mathrm{mm}\end{array}$ & $\begin{array}{c}\text { peso } \\
\text { ct. }\end{array}$ & $\begin{array}{l}\text { núm. } \\
\text { crist. }\end{array}$ & $\begin{array}{c}\text { peso } \\
\text { ct. }\end{array}$ & $\begin{array}{l}\text { núm. } \\
\text { crist. }\end{array}$ & $\begin{array}{c}\text { peso } \\
\text { ct. }\end{array}$ & $\begin{array}{c}\text { núm. } \\
\text { crist. }\end{array}$ & $\begin{array}{c}\text { peso } \\
\text { ct. } \\
\end{array}$ & $\begin{array}{l}\text { núm. } \\
\text { crist. }\end{array}$ & $\begin{array}{c}\text { peso } \\
\text { ct. }\end{array}$ & $\begin{array}{l}\text { núm. } \\
\text { crist. }\end{array}$ & $\begin{array}{c}\text { peso } \\
\text { ct. }\end{array}$ & $\begin{array}{l}\text { núm. } \\
\text { crist. }\end{array}$ & $\begin{array}{c}\text { peso } \\
\text { ct. }\end{array}$ & $\begin{array}{l}\text { núm. } \\
\text { crist. }\end{array}$ & $\begin{array}{c}\text { peso } \\
\text { ct. }\end{array}$ & $\begin{array}{l}\text { núm. } \\
\text { crist. }\end{array}$ & $\begin{array}{c}\text { peso } \\
\text { ct. }\end{array}$ & $\begin{array}{l}\text { núm. } \\
\text { crist. }\end{array}$ & $\begin{array}{c}\text { peso } \\
\text { ct. }\end{array}$ & $\begin{array}{l}\text { núm. } \\
\text { crist. }\end{array}$ \\
\hline$<$ & 0 & 0 & 0 & 0 & 0 & 의 & 0,3 & 4. & 2,96 & 98 & 1,21 & 35 & 0 & 0 & 2,22 & 89 & 0,3 & 1 & 0,65 & 18 \\
\hline 1,7 & 0,32 & 4 & 0,19 & 4 & 0,07 & 2 & 1,5 & 19 & 2,15 & 42 & 2. & 40 & 0,29 & 8 & 2,54 & 49 & 0,4 & 8 & 1,88 & 38 \\
\hline 1,9 & 0,88 & 11 & 0,4 & 5 & 0,31 & 7 & 2,8 & 30 & 2,99 & 43 & 2,39 & 35 & 0,46 & 9 & 3,28 & 48 & 0,29 & 4 & 2,74 & 39 \\
\hline 2,2 & 1,45 & 12. & 0,77 & 8 & 0,72 & 10 & 8 & 78 & 7,96 & 77 & 7,04 & 67 & 1,77 & 16 & 4,26 & 41 & 1,94 & 17 & 8,88 & 77 \\
\hline 2,5 & 1,42 & 9 & 0,59 & 4 & 1,53 & 16 & 7,6 & 52 & 6,36 & 43 & 4,35 & 29 & 1,82 & 14 & 4,7 & 31 & 1,07 & 8 & 10,21 & 69 \\
\hline 2,7 & 2,35 & 13 & 0,4 & 2 & 1,59 & 11 & 3,05 & 18 & 2,82 & 16 & 1,43 & 8 & 4,2 & 22 & 3,75 & 20 & 0,54 & 3 & 3,22 & 16 \\
\hline 3 & 3,75 & 15 & 1,37 & 6 & 0,89 & 5 & 8,55 & 36 & 13,69 & 60 & 6,43 & 28 & 3,41 & 14 & 10,96 & 45 & 1,11 & 5 & 16,62 & 70 \\
\hline 3,3 & 1,16 & 3. & 0,67 & 2 & 3,88 & 17 & 6,7 & 18 & 6,84 & 21 & 2,85 & 9 & 2,17 & 7 & 5,31 & 18 & 0 & 0 & 10,14 & 34 \\
\hline 3,6 & 1,76 & 5 & 0,37 & 1 & 2,06 & 7 & 11,1 & 29 & 9,14 & 22 & 3,69 & 10 & 5,17 & 13 & 8,17 & 20 & 0,38 & 1 & 17,39 & 44 \\
\hline 3,9 & 2,54 & 5 & 0 & 0 & 4,82 & 13 & 4,05 & 8 & 6,16 & 12 & 0,95 & 2 & 1,3 & 3 & 5,16 & 11 & 0,39 & 1 & 7,85 & 15 \\
\hline 4,1 & 2,84 & 5 & 0,63 & 1 & 2,64 & 6 & 4,55 & 9 & 7,03 & 11 & 1,06 & 2 & 0 & 0 & 3,51 & 6 & 0 & 0 & 14,36 & 24 \\
\hline 4,3 & 8,6 & 8 & 0 & 0 & 1,31 & 2 & 8,45 & 12 & 5,57 & 8 & 1,29 & 2 & 2,29 & 4 & 0 & 0 & 0 & 0 & 7 & 10 \\
\hline$>$ & 0 & 0 & 5,69 & 3 & 14,83 & 11 & 35,85 & 23 & 32,74 & 26 & 1,07 & 1 & 6,17 & 5 & 10,81 & 10 & 4,72 & 3 & 29,57 & 28 \\
\hline total & 27,07 & 90 & 11,08 & 36 & 34,65 & 107 & 102,5 & 336 & 106,42 & 479 & 35,76 & 268 & 29,05 & 115 & 64,67 & 388 & 11,14 & 57 & 130,51 & 480 \\
\hline
\end{tabular}

\begin{tabular}{|r|r|r|r|r|}
\hline Local & \multicolumn{2}{|c|}{$P x(3)$} & \multicolumn{2}{|c|}{$\mathrm{Pa}(1)$} \\
\hline $\begin{array}{c}\text { crivo } \\
\mathrm{mm}\end{array}$ & $\begin{array}{c}\text { peso } \\
\text { ct. }\end{array}$ & $\begin{array}{r}\text { núm. } \\
\text { crist. }\end{array}$ & $\begin{array}{c}\text { peso } \\
\text { ct. }\end{array}$ & $\begin{array}{r}\text { núm. } \\
\text { crist. }\end{array}$ \\
\hline$<$ & 0 & 0 & 0 & 39 \\
\hline $1,7-2,9$ & 0 & 426 & 0 & 1012 \\
\hline $2,9-3,5$ & 0 & 102 & 0 & 134 \\
\hline $3,5-4,3$ & 0 & 87 & 0 & 5 \\
\hline$>$ & 0 & 36 & 0 & 1 \\
\hline Total & 0 & 651 & 0 & 1191 \\
\hline
\end{tabular}

Tabela 4.2 - Em A estão reunidas as amostras das regiões de Chapada dos Guimarães (lotes CG1, CG2 e CG3), Poxoréu (lotes Px1 e Px2), Diamantino (lote Di1) e Alto Paraguai (lotes AP1, AP2, AP3 e AP4), distribuidas em intervalos granulométricos próximos entre si. A Tabela B em anexo, mostra dados de Poxoréu (lote Px3) e de Paranatinga (lote Paf) distribuidos em intervalos granulométricos mais amplos. 

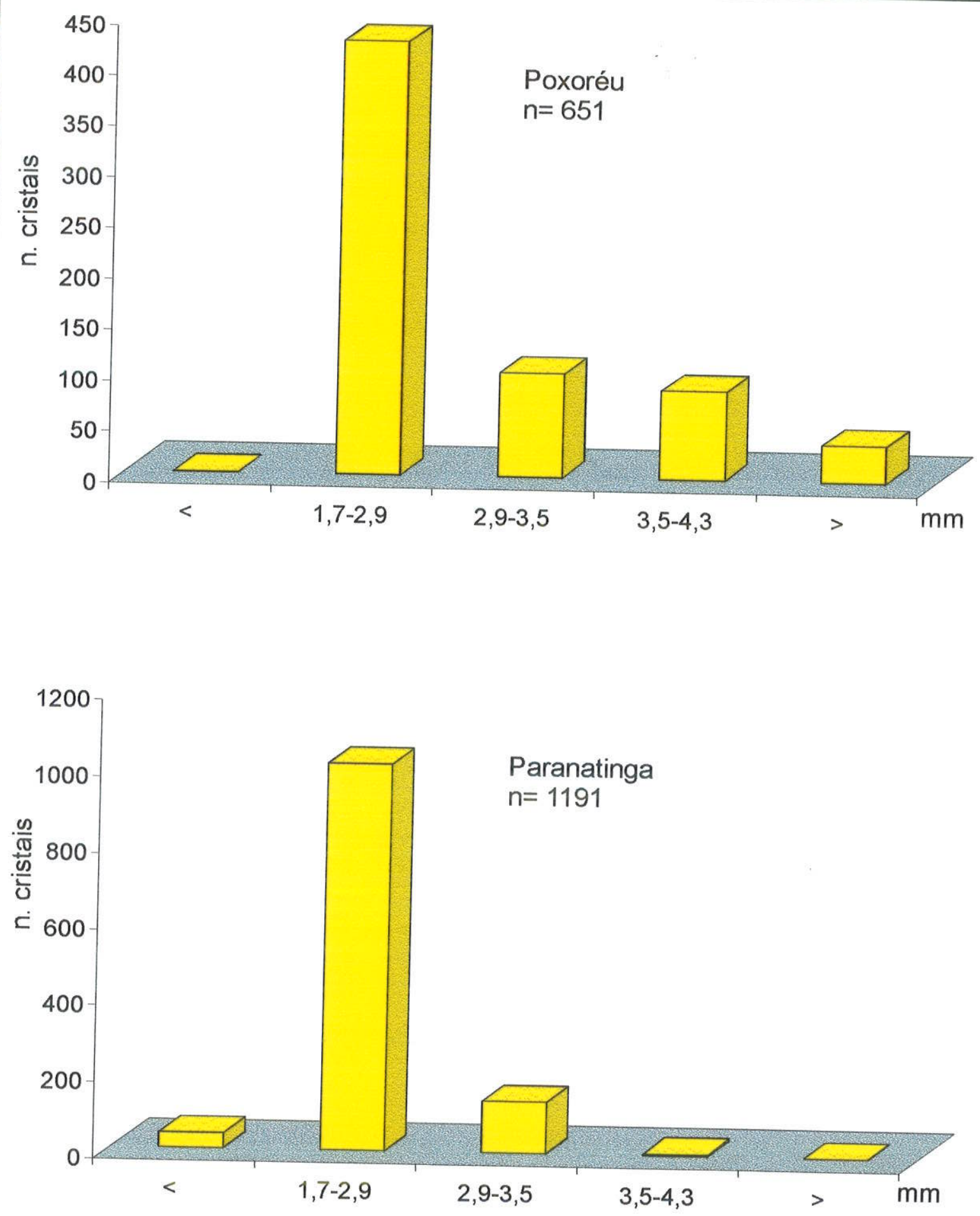

Figura 4.6 - Distribuição do número de cristais em função da granulometria em mm de diamantes das regiões de Poxoréu (lote Px 3) e Paranatinga (lote Pa 1). Observa-se que em ambos os casos a distribuição é unimodal ( $n=$ número total de cristais). 


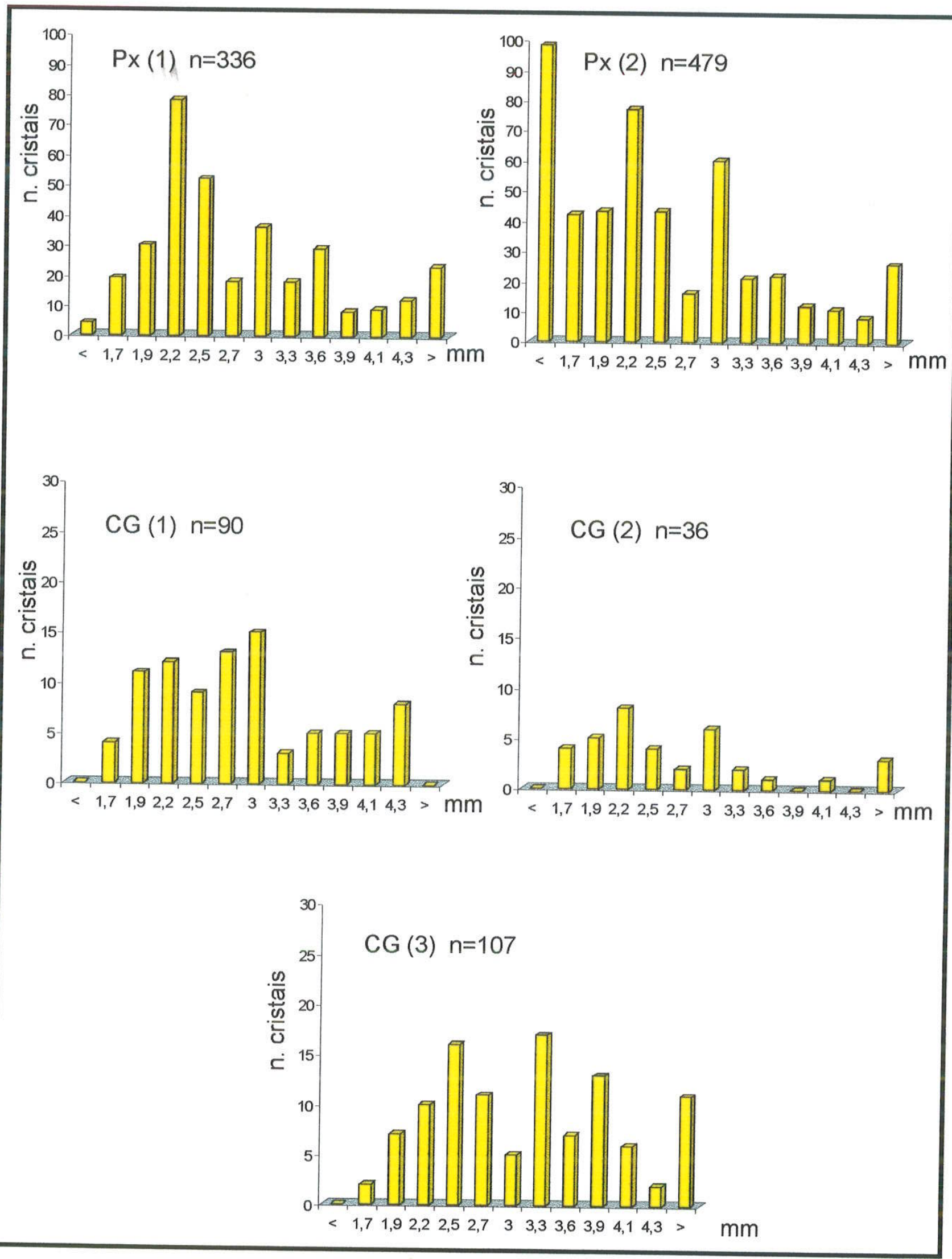

Figura 4.7 - Distribuição do número de cristais em função da granulometria em $\mathrm{mm}$ de diamantes das regiões de Poxoréu (lotes Px 1 e Px 2) e de Chapada dos Guimarães (lotes CG 1, CG2 e CG 3). Observa-se que nesses casos a distribuição é polimodal. 


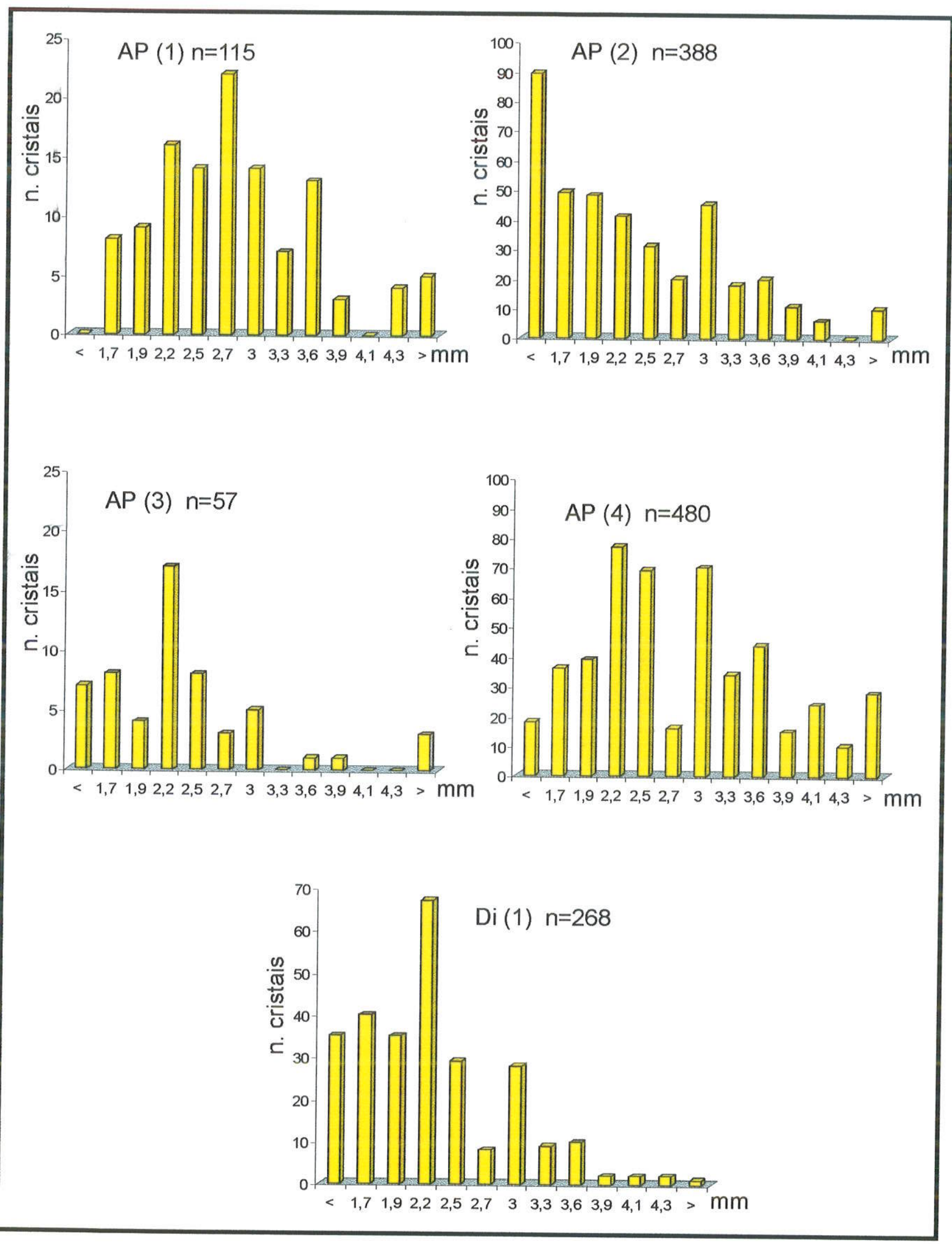

Figura 4.8 - Distribuição do número de cristais em função da granulometria em $\mathrm{mm}$ de diamantes das regiões de Alto Paraguai (lotes AP 1, AP 2, AP 3 e AP 4) e de Diamantino (lotes $\mathrm{Di} 1$ ). Tal como no caso anterior, a distribuição granulométrica nessas duas áreas é polimodal. 


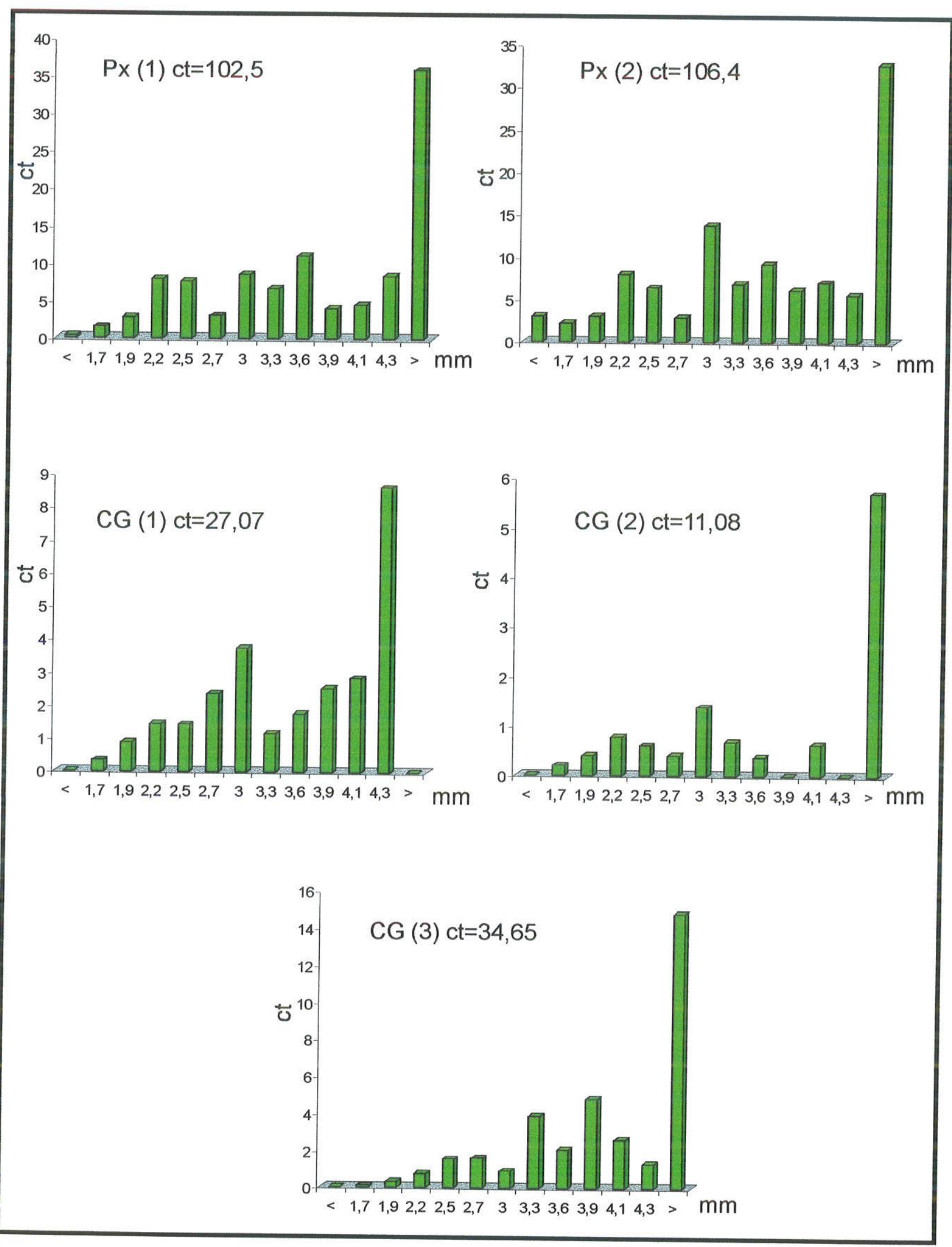

Figura 4.9 - Distribuição do peso em quilates em função da granulometria em $\mathrm{mm}$ de diamantes das regiões de Poxoréu (lotes Px 1 e Px 2) e de Chapada dos Guimarães (lotes CG 1, CG2 e CG 3). Observa-se que também nesse caso a distribuição é polimodal. 


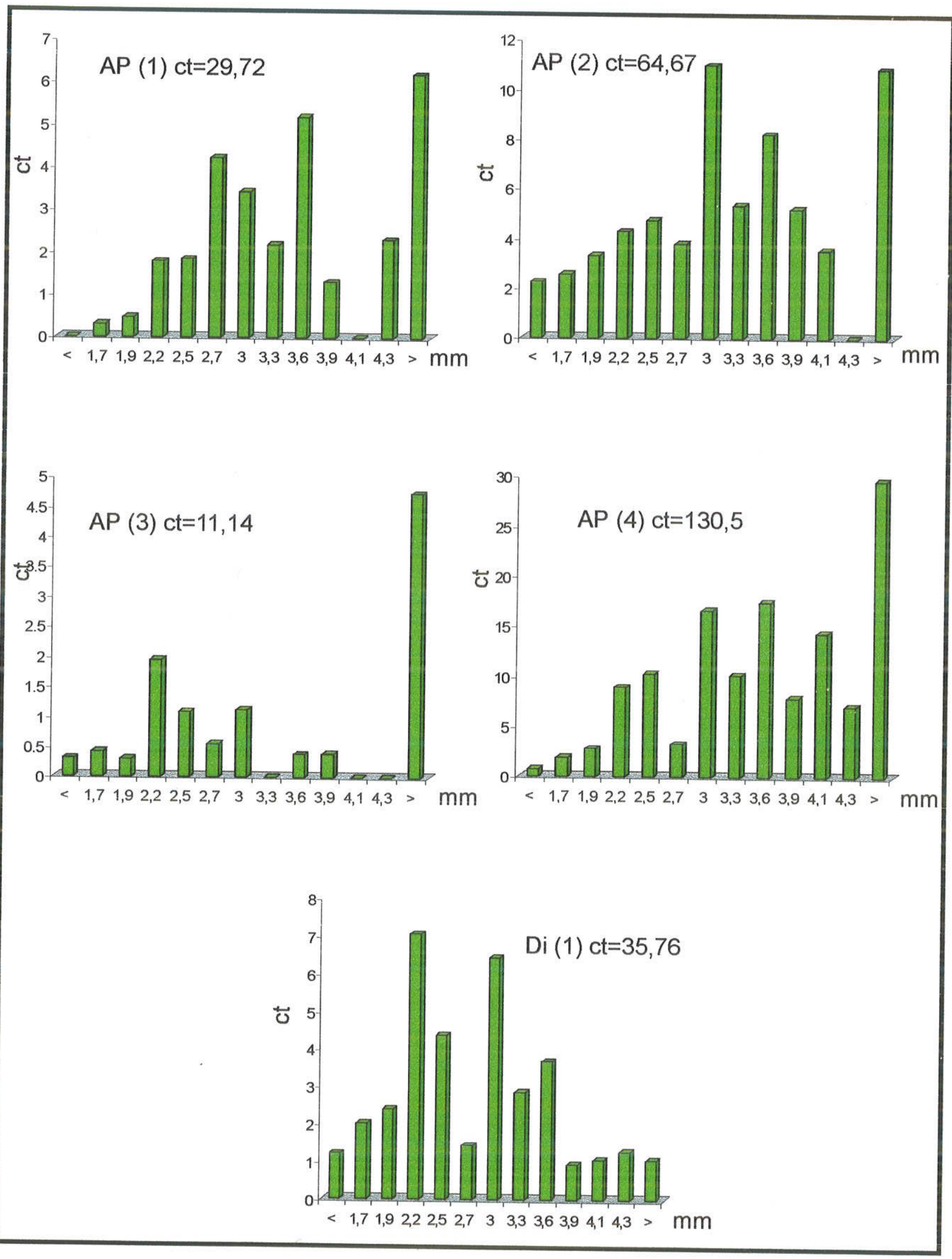

Figura 4.10 - Distribuição do peso em quilates em função da granulometria em $\mathrm{mm}$ de diamantes das regiões de Alto Paraguai (lotes AP 1, AP 2, AP 3 e AP 4) e de Diamantino (lote Di1). Como no caso anterior, a distribuição é polimoda. 
numérica e de peso), observa-se que nas frações menores ocorre um número maior de cristais, porém, de peso pequeno. Nas frações maiores ocorre o inverso, apesar de haver poucos cristais, o peso é maior.

Os cristais que se encontram agrupados no intervalo maior que o crivo $19(>4,3$ $\mathrm{mm})$, que é o limite granulométrico superior ou o maior intervalo granulométrico considerado neste trabalho, apresentam qualquer dimensão acima deste crivo. Desta forma, a última classe considerada pode apresentar a maior quilatagem. Para evitar uma interpretação errônea, este intervalo não deve ser considerado como predominante do lote analisado, mas sim como indicador da ocorrência de pedras grandes. Segundo garimpeiros e compradores de diamantes, pedras acima de 5 ct são relativamente raras em todas as áreas amostradas. Ocorrem principalmente em Poxoréu e Chapada dos Guimarães. Esse fato contrasta com os garimpos da região de Coromandel, onde são freqüentes os megadiamantes, ou seja, pedras acima de 50 quilates (Svisero 1995).

\subsection{Análise estatística}

A analise estatística da distribuição de freqüência granulométrica foi realizada com a finalidade de caracterizar precisamente a distribuição. Para tanto, primeiramente foi necessário montar o banco de dados das amostras, efetuando a substituição da malha (crivo) utilizada $(<, 1,7-1,9-2,2 \ldots .4,3>)$, por números fracionados $(0,5-1,5-2,5$ $3,5 \ldots . .12,5)$. Na Figura 4.11, consta a relação das malhas (crivo) correspondentes aos números fracionados utilizados. Esta substituição foi necessária porque os intervalos granulométricos considerados eram relativamente próximos e irregulares, podendo desta forma agrupar e inviezar o resultado. A regularização dos intervalos de classes, tornando-os mais distantes e constante, resultou em apenas uma peneira dentro de cada classe.

Os dados ordenados foram posteriormente tratados através do programa GSLib (Deutsch \& Journel 1996). A amostragem dos dados foi aleatória, onde a variável considerada foi a granulometria de lotes de diamantes provenientes de Chapada dos Guimarães, Poxoréu, Paranatinga, Diamantino e Alto Paraguai. O número de intervalo de classe ou amplitude de variação considerado foi 13 , sendo o valor mínimo 0.5 correspondendo a malha $<1,7 \mathrm{~mm}$ e o máximo 12.5 correspondendo a malha $>4,3$ 
Tabela 4.3 - Dados estatísticos dos lotes de diamantes amostrados.

\begin{tabular}{|c|c|c|c|c|c|}
\hline LOCALIDADE & LOTE & MÉDIA & $\begin{array}{l}\text { DESVIO } \\
\text { PADRÃOO }\end{array}$ & $\begin{array}{l}\text { COEFICIENTE } \\
\text { DE VARIAÇÃO }\end{array}$ & MEDIANA \\
\hline \multirow{4}{*}{$\begin{array}{l}\text { Chapada dos } \\
\text { Guimarães } \\
233 \text { amostras }\end{array}$} & CG (1) & $6.02 \cong 3,0 \mathrm{~mm}$ & $2.91 \cong 1.7 \mathrm{~mm}$ & $0.48 \cong(<1,7 \mathrm{~mm})$ & $5.5 \cong 2,7 \mathrm{~mm}$ \\
\hline & $\mathrm{CG}(2)$ & $5.17 \cong 2,7 \mathrm{~mm}$ & $3.06 \cong 2,2 \mathrm{~mm}$ & $0.59 \cong(<1,7 \mathrm{~mm})$ & $4.5 \cong 2,5 \mathrm{~mm}$ \\
\hline & CG (3) & $7.0 \cong 53,3 \mathrm{~mm}$ & $3.05 \cong 2,2 \mathrm{~mm}$ & $0.43 \cong(<1,7 \mathrm{~mm})$ & $7.5 \cong 3,3 \mathrm{~mm}$ \\
\hline & CG (total) & $6.36 \cong 3,0 \mathrm{~mm}$ & $3.08 \cong 2,2 \mathrm{~mm}$ & $0.48 \cong(<1,7 \mathrm{~mm})$ & $5.5 \cong 2,7 \mathrm{~mm}$ \\
\hline \multirow{3}{*}{$\begin{array}{c}\text { Poxoréu } \\
815 \text { amostras }\end{array}$} & $P \times(1)$ & $5.72 \cong 2,7 \mathrm{~mm}$ & $3.13 \cong 2,2 \mathrm{~mm}$ & $0.55 \cong(<1,7 \mathrm{~mm})$ & $4.5 \cong 2.5 \mathrm{~mm}$ \\
\hline & $P \times(2)$ & $4.49 \cong 2,5 \mathrm{~mm}$ & $3.46 \cong 2,2 \mathrm{~mm}$ & $0.77 \cong(<1,7 \mathrm{~mm})$ & $3.5 \cong 2,2 \mathrm{~mm}$ \\
\hline & Px (total) & $5.0 \cong 2,7 \mathrm{~mm}$ & $3.39 \cong 2,2 \mathrm{~mm}$ & $0.68 \cong(<1,7 \mathrm{~mm})$ & $4.5 \cong 2,5 \mathrm{~mm}$ \\
\hline $\begin{array}{c}\text { Diamantino } \\
268 \text { amostras }\end{array}$ & $\mathrm{Di}(1)$ & $3.67 \cong 2.2 \mathrm{~mm}$ & $2.43 \cong 1,7 \mathrm{~mm}$ & $0.66 \cong(<1,7 \mathrm{~mm})$ & $3.5 \cong 2,2 \mathrm{~mm}$ \\
\hline \multirow{5}{*}{$\begin{array}{l}\text { Alto Paraguai } \\
1040 \text { amostras }\end{array}$} & $\mathrm{AP}(1)$ & $5.81 \cong 2,7 \mathrm{~mm}$ & $2.77 \cong 1,7 \mathrm{~mm}$ & $0.48 \cong(<1,7 \mathrm{~mm})$ & $5.5 \cong 2,7 \mathrm{~mm}$ \\
\hline & $\mathrm{AP}(2)$ & $3.91 \cong 2,2 \mathrm{~mm}$ & $3.12 \cong 2,2 \mathrm{~mm}$ & $0.80 \cong(<1,7 \mathrm{~mm})$ & $3.5 \cong 2,2 \mathrm{~mm}$ \\
\hline & $\mathrm{AP}(3)$ & $3.93 \cong 2,2 \mathrm{~mm}$ & $2.83 \cong 1,7 \mathrm{~mm}$ & $0.72 \cong(<1,7 \mathrm{~mm})$ & $3.5 \cong 2,2 \mathrm{~mm}$ \\
\hline & $\mathrm{AP}(4)$ & $5.78 \cong 2,7 \mathrm{~mm}$ & $3.19 \cong 2,2 \mathrm{~mm}$ & $0.55 \cong(<1,7 \mathrm{~mm})$ & $5.5 \cong 2,7 \mathrm{~mm}$ \\
\hline & AP (total) & $4.98 \cong 2,5 \mathrm{~mm}$ & $3.24 \cong 2,2 \mathrm{~mm}$ & $0.65 \cong(<1,7 \mathrm{~mm})$ & $4.5 \simeq 2,5 \mathrm{~mm}$ \\
\hline
\end{tabular}

Obs: os valores foram considerados aproximados a cada malha ou crivo, porque durante a análise estatística foram usados os números fracionados e não os milimetros correspondentes a cada intervalo granulométrico observado. Por exemplo, a média 6,02 encontra-se entre a classe 6 e 7, no entanto, o número 6.5 que corresponde ao crivo $2,7 \mathrm{~mm}$, ou seja 6,02 é o valor aproximado de $2,7 \mathrm{~mm}$ e não de 5.5 que é correspondente ao crivo $2,5 \mathrm{~mm}$. 
$\mathrm{mm}$. Os resultados obtidos encontram-se relacionados na Tabela 4.3. Os histogramas e os gráficos de freqüência acumulada estão representados nas Figuras $4.11,4.12$ e 4.13. Nestas figuras, pode-se observar a assimetria, a moda e a mediana, dados estes que serão discutidos por região amostrada.

\subsubsection{Chapada dos Guimarães}

No histograma do lote CG (1), observa-se que a moda e a média coincidem $(6.02 \cong 3,0 \mathrm{~mm})$ e que a moda representa $16.5 \%$ da amostra. Ocorrem também outras classes de maior freqüencia (malhas 3,4 e 6), que apesar de representativas, não deslocam a média em relação à moda. A distribuição é relativamente simétrica e, observa-se também que $9 \%$ da amostra encontra-se acima da fração $4,3 \mathrm{~mm}$ (Figura 4.11).

No histograma do lote CG (2) observa-se que a moda $(2,2 \mathrm{~mm})$ e a média $(2,7$ $\mathrm{mm}$ ) diferem, estando deslocadas uma em relação a outra, devido a presença de outras classes de maior freqüência (malhas 3 e 7); a moda representa $22 \%$ da amostra; a assimetria é positiva, indicando que ocorre um maior número de pedras nas classes granulométricas inferiores, no entanto, $8 \%$ da amostra encontra se acima de 4,3 mm (Figura 4.11).

O histograma do lote CG (3) apresenta a média e a moda coincidindo, apesar de ocorrerem outras classes de maior freqüência (malhas 5, 10 e 13); a curva é assimétrica negativa, com o maior número de cristais nas classes granulométricas superiores. Neste caso, o gráfico apresenta quatro classes de maior freqüência (Figura 4.11). Ressalta-se também que $10 \%$ das amostras encontram-se acima da fração 4,3 $\mathrm{mm}$.

A assimetria do histograma é ocasionada pelos valores extremos que não foram considerados outlier (desprezados) porque os cristais que ficaram retidos nas frações granulométricas da extrema direita são mais representativos economicamente.

O gráfico de freqüência acumulada, em escala logarítmica, permite observar melhor se ocorre ou não a presença de várias populações. Para compreender a distribuição da população neste gráfico, deve-se observar que a altura de cada degrau (na abcissa), corresponde a freqüência de cristais em cada intervalo granulométrico, que estão representados na ordenada. Desta forma os degraus representam a 

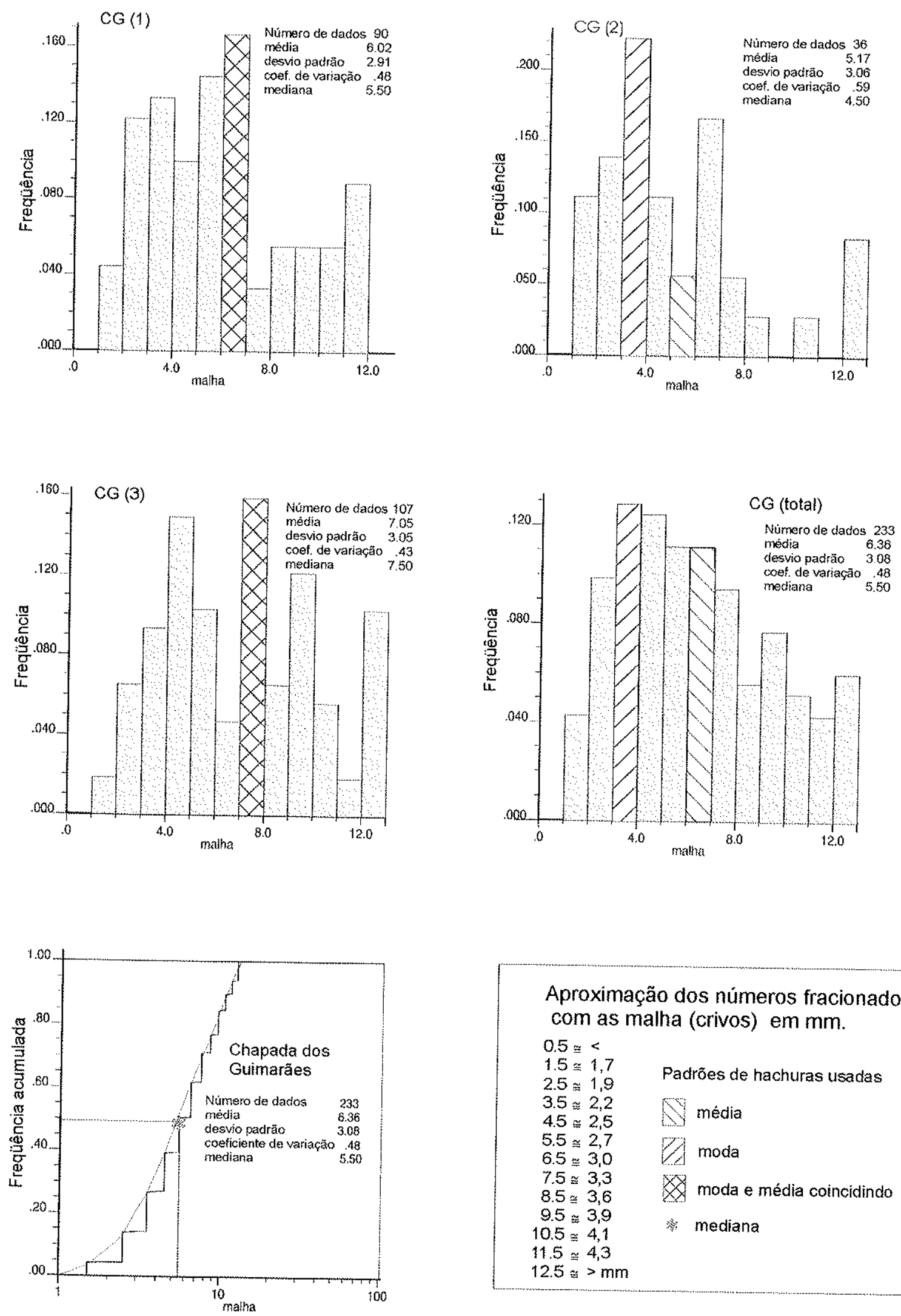

Aproximação dos números fracionados, com as malha (crivos) $\mathrm{em} \mathrm{mm}$.

$0.5 \cong$

$1.5 \cong 1,7$ Padrões de hachuras usadas

$2.5 \approx 1,9$

$3.5 \cong 2,2$

$4.5 \div 2,5$

$5.5 \simeq 2,7$

$6.5 \div 3,0$

$7.5 \cong 3,3$

$8.5 \cong 3,6$

$9.5 \approx 3,9$

$10.5 \approx 4,1$

Nédia

87 moda

moda e média coincidindo

$11.5 \cong 4,3$

翟 mediana

$12.5 \cong>\mathrm{mm}$

Figura 4.11 - Histogramas de distribuição de freqüência granulométrica e o respectivo gráfico de freqüência acumulada referente ao diamante da região de Chapada dos Guimarães (lotes CG1, CG2, CG3 e CG total), Mato Grosso. 
freqüência do número de cristais em cada classe.

O gráfico de freqüência acumulada dos lotes da região de Chapada dos Guimarães mostra que somente $5 \%$ dos diamantes analisados estão abaixo da fração granulométrica $1,7 \mathrm{~mm}$ e portanto não são lapidáveis. A mediana (5.50) evidenciou que $50 \%$ da população encontra-se acima da granulometria $2,7 \mathrm{~mm}$, e que, pela observação visual da sinuosidade da curva possivelmente ocorrem duas populações distintas (Figura 4.11).

\subsubsection{Poxoréu}

No histograma do lote $\mathrm{Px}$ (1), a moda localiza-se na fração $2,2 \mathrm{~mm}$ representando aproximadamente $23 \%$ da amostra; a média encontra-se deslocada em relação a moda devido a ocorrência de outras classes de maior freqüência (malhas $5 \mathrm{e}$ 7). A assimetria é positiva; além disso observa-se também que $7 \%$ da amostra está acima da malha (crivo) 4,3 $\mathrm{mm}$ (Figura 4.12).

No histograma do lote $\mathrm{Px}$ (2) a moda localiza-se na fração $<1,7 \mathrm{~mm}$, equivalendo a 20,5\% da amostra. A média está deslocada em relação a moda devido a ocorrência de outras classes de maior freqüência (malhas 4 e 7), e a assimetria é positiva. Neste lote apenas $5 \%$ das amostras apresentam granulometria maior que 4,3 $\mathrm{mm}$ (Figura 4.12).

O gráfico de freqüência acumulada dos lotes de diamantes de Poxoréu, permite observar que $22 \%$ dos diamantes encontram-se abaixo da fração $1,7 \mathrm{~mm} ; 50 \%$ da população está acima da granulometria $2,5 \mathrm{~mm}$, ocorrendo aproximadamente três populações distintas de diamantes, observada através da visualização da sinuosidade da curva (Figura 4.12).

\subsubsection{Diamantino}

No histograma do lote (Di 1) a média e a moda coincidem na mesma fração granulométrica $2,2 \mathrm{~mm}$, sendo a assimetria positiva. $O$ gráfico de freqüência acumulada sugere a presença de aproximadamente três populações (observação visual da sinuosidade da curva). Além disso, o valor da mediana (3.5) mostra que $50 \%$ da amostra estão acima da fração $2,2 \mathrm{~mm}$ e, que $20 \%$ são constituídos por cristais não 

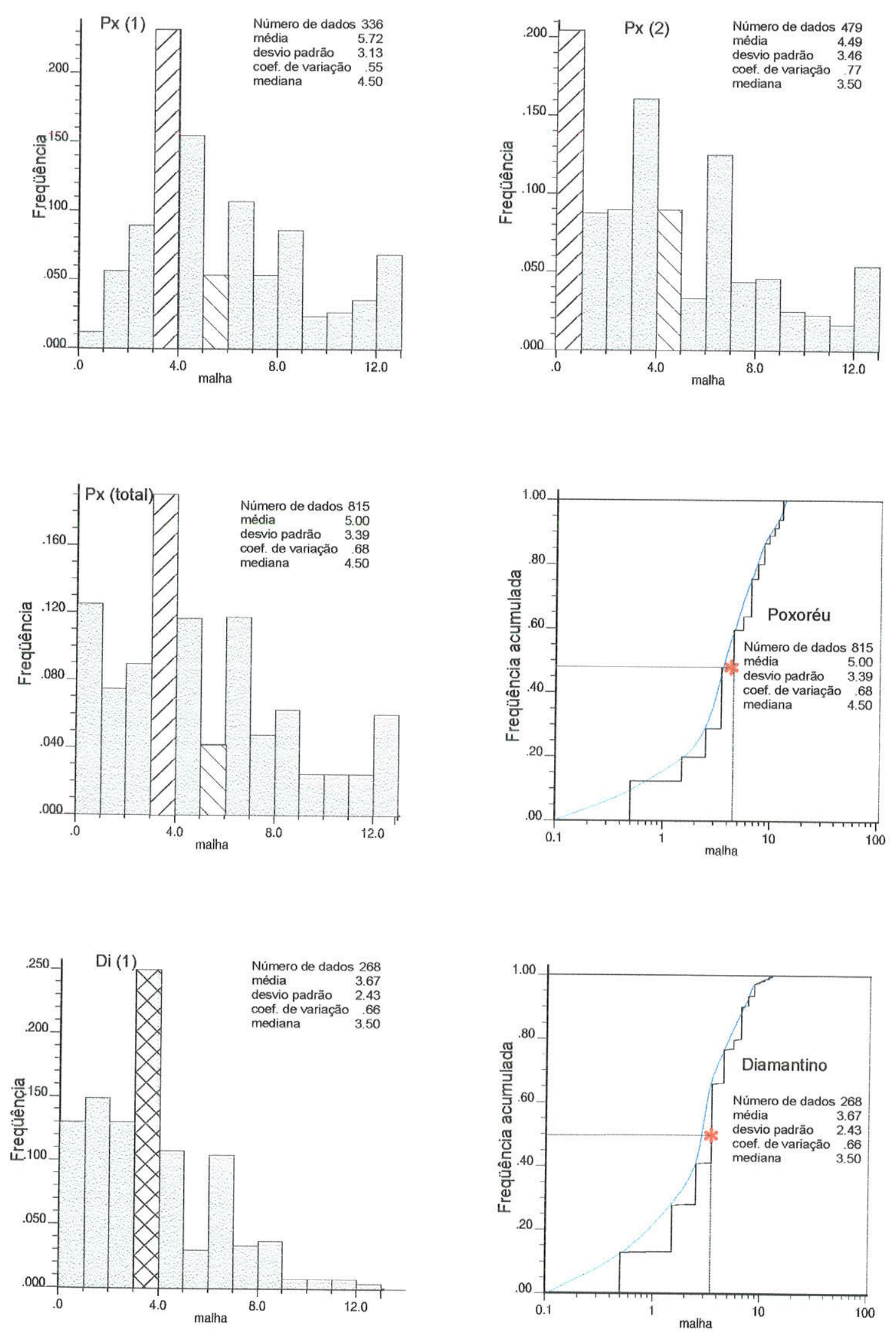

Figura 4.12 - Histogramas de distribuição de freqüência granulométrica e os respectivos gráficos de freqüência acumulada referente ao diamante das regiões de Poxoréu (lotes Px1, Pxe Px total) e Diamantino (lote Di1), Mato Grosso. 
lapidáveis, ou seja estão abaixo de 1,7 mm (Figura 4.12).

\subsubsection{Alto Paraguai}

O histograma do lote AP (1) apresenta a média e a moda coincidindo; a moda representa $18 \%$ da amostra, ocorrem mais quatro classes de maior freqüência (malhas 4, 5, 7 e 9). A curva é relativamente simétrica; aproximadamente $4 \%$ da amostra ocorre acima da classe granulométrica $4,3 \mathrm{~mm}$ (Figura 4.13).

O histograma do lote AP (2) mostra que a média e a moda diferem; ocorre apenas mais uma classe de maior freqüencia (malha 7). A assimetria é fortemente positiva; e somente $3 \%$ da amostra está acima de 4,3 mm (Figura 4.13).

No histograma do lote AP (3) a média e a moda coincidem; a curva é simétrica; as outras classes são relativamente baixas em relação a moda, que representa $30 \%$ da amostra; o número de amostras é relativamente baixo no entanto $5 \%$ encontram-se acima da fração 4,3 mm (Figura 4.13).

No histograma do lote AP (4) a moda e a média diferem; ocorrem outras classes de maior freqüência (malhas 5, 7 e 9) além da moda; a curva é relativamente simétrica e $6 \%$ das amostras encontram-se acima de 4,3 $\mathrm{mm}$ (Figura 4.13).

O gráfico de freqüência acumulada evidencia através da mediana (4.5) que 55\% das amostras encontram-se acima da fração $2,5 \mathrm{~mm}$ e que apenas $10 \%$ cristais estão abaixo da fração $1,7 \mathrm{~mm}$ (que devido ao tamanho não são lapidáveis). O gráfico sugere ainda pela sinuosidade da curva que existem aproximadamente três populações diferentes.

A mediana divide a população em $50 \%$ e, se for observada em associação com a inclinação da curva cumulativa ( que reflete as classes granulométricas), indica qual o tamanho médio da população de um determinado depósito. No entanto, em se tratando de diamante, cabe ressaltar que a presença de apenas uma pedra grande entre cristais de granulometria fina pode tornar o depósito economicamete viável. Por isso, a mediana é apenas um valor de referência. Entretanto, se os dados estatísticos forem associados a parâmetros sedimentológicos torna-se possível estimar a granulometria do diamante no depósito. 

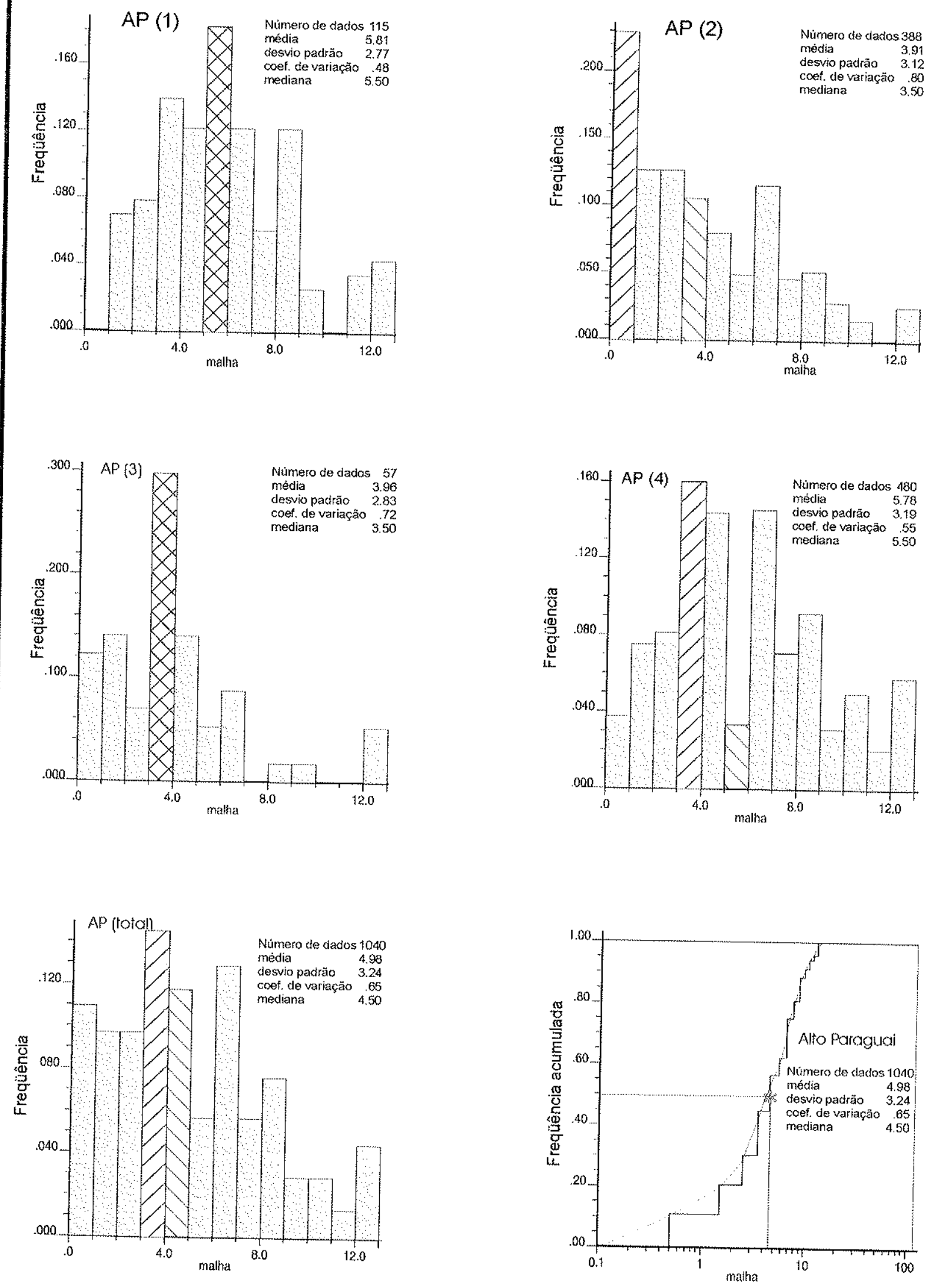

Figura 4.13 - Histogramas de distribuição de freqüência granulométrica e o respectivo gráfico de freqüência acumulada referente ao diamante da região de Alto Paraguai (lotes
AP1, AP2, AP3, AP4 e AP total), Mato Grosso. 


\subsection{Discussão}

A granulometria do diamante em fontes primárias é decorrente dos processos que atuaram no manto durante sua cristalização e de reabsorção tardia ou eventos de oxidação durante a colocação ou intrusão do magma kimberlítico. Nestas fontes ocorre um aumento exponencial do número de diamantes com a diminuição da granulometria (em decorrência da reabsorção), caracterizando uma distribuição contínua e unimodal (Romboust 1995). Além disso, a granulometria pode variar desde cristais diminutos a pedras de várias centenas de quilates em kimberlitos; sendo que somente pedras acima de 0,02 ct $(1,7 \mathrm{~mm})$ apresentam interesse econômico. Whitelock (1973) observou uma distribuição unimodal no Complexo Kimberlítico Kao (Figura 4.1) e Otter et al. (1994) no Complexo Kimberítico Sloam 1 e 2 (Figura 4.3).

Em depósitos secundários o que ocorre é que alguns agentes geológicos são mais efetivos, podendo manifestar maior ou menor selecionamento de diamantes em função do tamanho, forma e densidade. Além disso, a alta resistência do diamante faz com que sejam necessários vários quilômetros para que ocorra uma seleção representativa, onde os cristais menores vão se depositando junto com as areias, os maiores com os seixos e matacões, e os diamantes de qualidade inferior sejam destruídos devido a maior fragilidade ao choque. Segundo Gurney (1989), devido a sua alta dureza e resistência a ataques químicos, ele tende a permanecer em depósitos sedimentares, sobrevivendo até mesmo a eventos metamórficos.

Sutherland (1982) descreve a variação sistemática do tamanho e da qualidade de diamantes resultantes dos processos de transporte fluvial e marinho. A conclusão deste autor é que diamantes de áreas fontes relativamente restritas, podem ser transportados e distribuídos por muitas centenas de quilômetros por rios do sistema atual de drenagens. Estando o depósito secundário localizado próximo à fonte, deve-se levar em consideração que a fonte primária destes diamantes pode produzir pedras de alta qualidade e pequena proporção de diamantes de qualidade inferior, tal como em Lichtenburg na África do Sul (Du Toit 1951, In: Sutherland 1982). Pode ocorrer também, durante a incisão dos sistemas de rios atuais, o subseqüente retrabalhamento e a reconcentração de depósitos que não apresentavam concentrações suficientes para serem de interesse econômico, como por exemplo, conglomerados diamantíferos depositados durante o Cretáceo entre Zaire e Angola que formaram depósitos 
economicamente viáveis a $600 \mathrm{~km}$ da fonte (Sutherland 1982).

Segundo Campos \& Gonzaga (1999), os sedimentos glaciogênicos destacariamse em relação a outros, por apresentarem uma capacidade de transporte de centenas de quilômetros. Quando houver ocorrências diamantíferas distribuídas por uma grande região, deve-se esperar a presença de várias fontes, primárias ou secundárias, ao longo de todo o sistema fluvial, já que de uma forma geral, os minerais pesados (entre estes o diamante) não são transportados por longas distâncias em regimes fluviais, pois estes minerais ficariam retidos nas várias modalidades de armadilhas existentes nas regiões proximais às fontes.

Dependendo do mecanismo de transporte, ocorrem variações que influenciam significantemente na distribuição dos cristais dentro do placeres. Segundo Campos \& Gonzaga (1999) são encontrados depósitos diamantíferos nos sistemas fluviais de leques aluviais, rios entrelaçados, rios meandrantes e em depósitos resultantes da interação destes três sistemas; além destes também apresentam elevado potencial para acumulação de minerais pesados os ambientes flúvio-glaciais e canais subglaciais (zona basal de geleira). Os mecanismos de transporte (fluvial e glacial) são influenciados por variações climáticas (períodos de enchentes, enxurradas e estiagens ocasionando aumento ou diminuição da energia de transporte ou de intensidade de fluxo; variações de temperatura no caso das geleiras, entre outros) e de feições geológicas (arcabouço tectônico, evolução geomorfológica, formas de leitos etc.) que ocasionam diferentes tipos de armadilhas onde os diamantes tendem a se depositar. Esses fatores associados ou não, contribuem na distribuição da granulometria, na qualidade do diamante dentro do plácer e na distância em que ocorre a deposição com relação à área fonte. Portanto, devido a estes fatores, o diamante é modificado diminuindo o tamanho médio e aumentando a qualidade, com a destruição dos tipos inferiores.

Observa-se na Figura 3.1, que os rios das regiões onde os diamantes foram amostrados cortam unidades sedimentares descritas na literatura como diamantíferas. Nas regiões de Diamantino e Alto Paraguai, os rios cortam os sedimentos da Formação Utiariti (Grupo Parecis); na região de Paranatinga, cortam tanto a Formação Utiariti ao norte, como também as rochas kimberlíticas da Província Kimberlítica de Paranatinga; em Chapada dos Guimarães e Poxoréu cortam sedimentos da unidade equivalente ao Grupo Bauru (Weska 1996a).

As fontes primárias kimberlíticas Sloan 1 e 2 e Kimberlito Kao, abordadas neste 
trabalho apresentam uma distribuição granulométrica de diamante unimodal; porém, devido ao número de trabalhos encontrados na literatura referentes a este assunto serem escassos, não se pode afirmar que a unimodalidade granulométrica do diamante observada nestas fontes seja padrão para todas as intrusões kimberlíticas. Contudo, é possível sugerir que o comportamento polimodal dos lotes de diamantes aqui estudados pode estar refletindo a mistura de várias fontes, relacionadas a complexos kimberlíticos e/ou a fontes secundárias diamantíferas, que estariam abastecendo os aluviões através do sistema atual de drenagens. Além disso, observou-se também que a freqüência granulométrica decresce com o aumento do tamanho, sendo raras as pedras acima de 4,3 $\mathrm{mm}$. A raridade de diamantes grandes, pode estar relacionada a transportes por longas distâncias. No entanto, é importante ressaltar que os lotes estudados são provenientes de regiões diamantíferas e não de um aluvião em particular. Portanto, para comprovar estas interpretações são necessários estudos pormenorizados sobre a distribuição dos diamantes nos aluviões, bem como os diversos fatores envolvidos na formação destes depósitos. 


\section{MORFOLOGIA CRISTALINA}

A morfologia do diamante é uma das características mais notáveis desse mineral constituindo uma das evidências dos complexos fenômenos físico-químicos que atuam sobre os individuos cristalinos durante a cristalização, e também durante o transporte pelo magma kimberlítico (Meyer 1985). Esses fatores combinados entre si, terminam por impor ao diamante uma série de feições morfológicas tais como: presença de formas cristalográficas transicionais, faces e arestas curvas, cristais parcialmente reabsorvidos, geminações complexas, entre outras. Desde os trabalhos clássicos de Fersman \& Goldschimidt (1911), essas questões vêm sendo abordadas por diversos pesquisadores, entre os quais podem ser citados Sutton (1928), Willians (1932), Tolansky (1960), Orlov (1977), Sunagawa (1984), Mendelssohn \& Milledge (1995), entre outros.

Dados morfológicos a respeito dos grandes diamantes brasileiros já referidos no Capítulo 4 foram reunidos por Reis (1959). Estudos específicos sobre a caracterização de propriedades físicas e morfológicas de lotes de diamantes representativos de garimpos do Triângulo Mineiro (MG) e Alto Araguaia (MT), foram apresentados pela primeira vez por Leite (1969) e Svisero (1971), respectivamente. Posteriormente, Svisero et al. (1981) efetuou uma caracterização física e morfológica do diamante da Mina de Romaria, (MG). Trabalhos semelhantes foram executados por Chieregati (1989) na região do Tibagi (PR), Chaves (1997) na região da Serra do Espinhaço (MG), e Andrade (1999) na Chapada Diamantina (BA).

Dando continuidade a esses trabalhos, são apresentados nesta dissertação os resultados de estudos morfológicos de diamantes detríticos das regiões de Chapada dos Guimarães, Poxoréu, Paranatinga, Diamantino e Alto Paraguai (MT). Para facilitar a discussão das propriedades morfológicas dos cristais estudados, será apresentado a seguir algumas considerações cristalográficas desse mineral.

\subsection{Aspectos cristalográficos}

A estrutura interna do diamante, relativamente simples quando comparada com a morfologia externa complexa, foi uma das primeiras estruturas determinadas por Bragg \& Bragg (1913). Trata-se de uma estrutura cúbica de faces centradas, contendo 
em adição quatro átomos situados no interior da rede, perfazendo um total de oito átomos por cela unitária. Com relação aos átomos situados no interior da rede, dois estão localizados ao longo de uma das diagonais do cubo (coordenadas $1 / 4$ e $1 / 4$ ), e outros dois ao longo da diagonal oposta (coordenadas $3 / 4$ e $3 / 4$ ), conforme está ilustrado na Figura 5.1 a e b. O grupo espacial é Fd3m e o parâmetro da cela unitária $3,57 \AA$.

Neste tipo de estrutura, cada átomo de carbono é rodeado por outros quatro átomos dispostos nos vértices de um tetraedro regular e ligados uns aos outros por meio de ligações covalentes muito fortes, uma vez que a distância entre os átomos de carbono é de apenas $0,1544 \mathrm{~nm}\left(1\right.$ nanômetro $\left.=10^{-9} \mathrm{~m}\right)$. A existência de variações na densidade atômica dos diferentes planos reticulares é responsável pela anisotropia das propriedades mecânicas do diamante, tais como dureza, clivagem, entre outras (Bakon \& Szymanski 1993). O plano (111) possui a mais alta densidade atômica, a qual diminui sequencialmente nos planos (110) e (100). Considerando a densidade do plano (100) como 1, os valores de (111) e (110) são, respectivamente 2,308 e 1,414 respectivamente (Lenzen 1983).

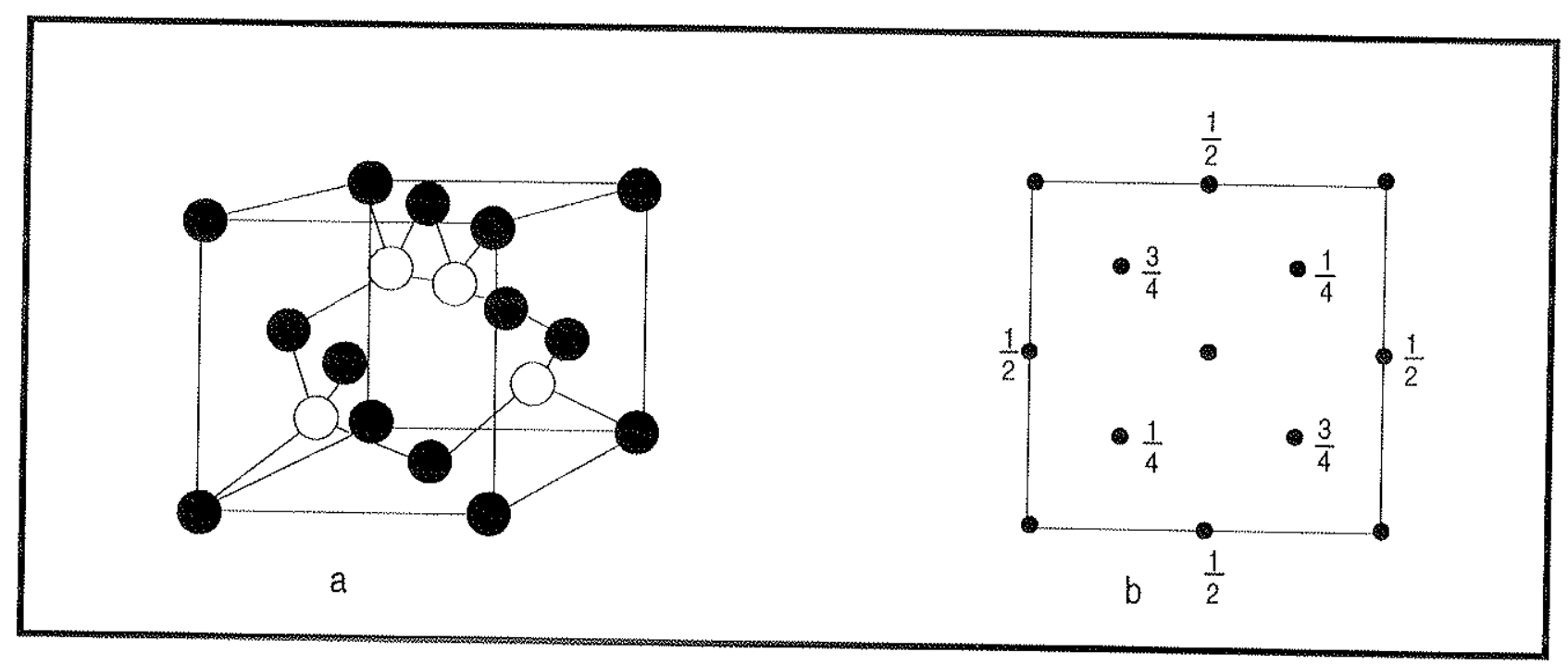

Figura 5.1 - Estrutura cristalina do diamante: a) Estrutura tridimensional cúbica de faces centradas contendo oito átomos por cela unitária. Observa-se que além dos átomos presentes nos vértices e nos centros das faces, a estrutura contém ainda quatro átomos no interior do cubo situados em planos diagonais perpendiculares entre si; b) Projeção da estrutura anterior no plano (001) para facilitar a visualização das coordenadas relativas dos átomos na rede. 
Embora a estrutura do diamante tenha sido uma das primeiras a ser conhecida, o grau de simetria (grupo pontual) desse mineral, constituiu durante muito tempo um dos grandes problemas da literatura mineralógica. No início, os pesquisadores notaram que os cristais eram constituídos, em sua maior parte por formas simples e/ou combinadas do sistema cúbico, predominando sempre formas transicionais entre o octaedro $\{111\}$ e o rombododecaedro $\{110\}$, seguidas de formas cúbicas e geminados. As feições morfológicas observadas eram compatíveis com o grau de simetria holoédrico $(\mathrm{m} 3 \mathrm{~m})$.

A presença de formas aparentemente hexatetraédricas, por outro lado, descritas por vários autores (Fersman \& Goldschimidt 1911, Golchimidt 1916), indicavam em princípio que o diamante poderia cristalizar-se na classe antihemiédrica $(\overline{4} 3 \mathrm{~m})$ do sistema cúbico. Nesse caso, a presença do octaedro poderia ser explicada como sendo resultante da combinação dos tetraedros $\{111\}$ e $\{111\}$. O cubo $\{100\}$ e o rombododecaedro $\{110\}$, por outro lado, sendo formas singônicas do sistema cúbico poderiam estar presentes também na classe antihemiédrica, constituindo formas simples ou combinadas com outras formas cristalográficas da classe.

Essa problemática, de ser o diamante holoédrico $(\mathrm{m} 3 \mathrm{~m})$ ou antihemiédrico ( $\overline{4} 3 \mathrm{~m})$, foi discutida exaustivamente por Fersman \& Goldschimidt (1911) no trabalho Der Diamant, no qual os referidos autores concluíram ser este mineral antihemiédrico. A determinação da estrutura cristalina do diamante efetuada por Bragg \& Bragg (1913) não resolveu a questão, uma vez que na difração de raios $X$, qualquer substância desprovida de centro de simetria comporta-se como se tivesse aquele elemento de simetria. Van der Veen (1913), procurou detectar a presença do efeito de piezeletricidade no diamante, o que em princípio poderia indicar a ausência de centro de simetria, mas os seus resultados foram inconclusivos. Dessa forma, o problema foi se arrastando pelas décadas seguintes tendo sido rediscutido por Sutton (1928), Willians (1932), Tolansky (1965) e Leite (1969) e Svisero (1971), interpretou a morfologia do diamante da região do Alto Araguaia admitindo grau holoédrico; as formas pseudo-hexatetraédricas, foram interpretadas como sendo resultantes da dissolução de formas cúbicas primárias (primitivas). Mais recentemente, Yacoot e Moore (1993), comprovaram pelo método de topografia de raios $X$, que o diamante possui simetria cúbica holoédrica $\mathrm{m} 3 \mathrm{~m}$.

Tendo em vista que o grau de simetria do diamante é holoédrico, a discussão de qualquer aspecto morfológico do diamante deve levar em conta que as úncias formas 
cristalográficas simples, possiveis de ocorrer nos cristais desse mineral são: cubo, rombododecaedro, octaedro, cubo piramidado, trioctaedro, icositetraedro e hexaoctaedro (Figura 5.2). Além de combinações entre as formas simples acima referidas, são possíveis também, em princípio, a ocorrência de geminações que podem ser simples ou complexas (Figura 5.3).

\subsection{Classificação morfológica}

A morfologia do diamante varia não somente entre espécimes provenientes de localidades diferentes, mas também entre amostras de uma única fonte, seja ela primária ou secundária (Mendelssohn \& Milledge 1995). O conhecimento das variações morfológica exibidas pelo diamante tem interesse acadêmico, uma vez que elas refletem os complexos fenômenos que acompanham e seguem a cristalização do diamante. Por outro lado, há um interesse prático em conhecer essa classificação tendo em vista que os diamantes possuem aplicações e usos dependentes de suas características físicas e morfológicas.

A classificação dos aspectos morfológicos dos diamantes estudados nesta dissertação está apoiada nos princípios utilizados nos trabalhos pioneiros de Leite (1969) e Svisero (1971), referentes a diamantes de garimpos brasileiros, e nos de Whitelock (1973) e Harris et al. (1975, 1979), McCallum et al. (1979, 1994), Otter et al. (1994) referentes a diamantes de kimberlitos africanos e norte americanos. Esses trabalhos foram ampliados posteriormente para regiões especificas tais como a Mina de Romaria (Svisero et al. 1981), região do Tibagi (Chieregati 1989), Serra do Espinhaço (Chaves 1997) e Chapada Diamantina (Andrade 1999).

Os dados morfológicos discutidos nos itens subseqüentes foram obtidos seguindo o esquema apresentado nas Tabela 2.1 e 2.2 discutidas no Capítulo 2 . Resumidamente a Tabela 2.1 reune as informações físicas discutidas neste trabalho, com exceção do comportamento no infravermelho, composição isotópica e catodoluminescência, as quais serão abordadas em trabalhos posteriores. Observa-se que o item Forma cristalográfica, prevê a ocorrência de formas simples da classe holoédrica $\mathrm{m} 3 \mathrm{~m}$, de combinações entre estas formas, geminações, fragmentos de clivagem, cristais irregulares, agregados cristalinos e policristalinos (carbonados e ballas). A Tabela 2.2 prevê a distribuição das variedades morfológicas em função do 


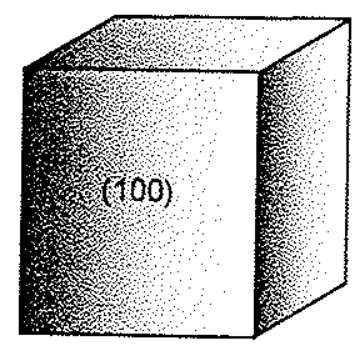

$\{100\}$ - cubo

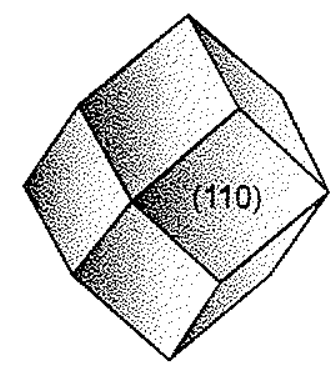

$\{110\}$ - rombododecaedro

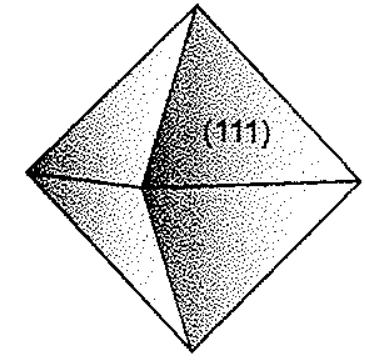

$\{111\}$ - octaedro

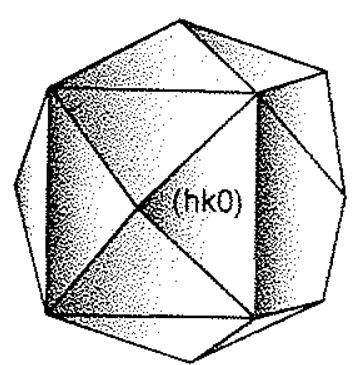

$\{h k 0\}$ - cubo piramidado

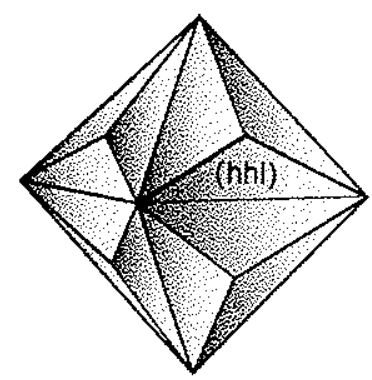

$\{$ hhl\} - trioctaedro

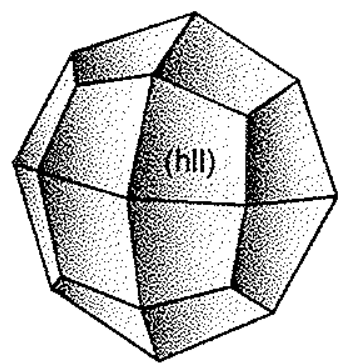

$\{$ hnl\} - icositetraedro

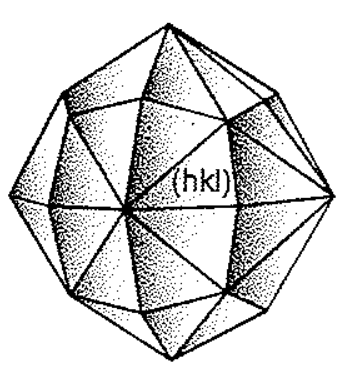

$\{$ hkl\} - hexaoctaedro

Figura 5.2 - Formas cristalográficas simples da classe $\mathrm{m} 3 \mathrm{~m}$ (holoédrica) do sistema cúbico. Entre essas formas, o octaedro e o momento em cristais de formas mais freqüentes em diamantes naturais. O icositetraedro é a única forma não descrita até o presente 


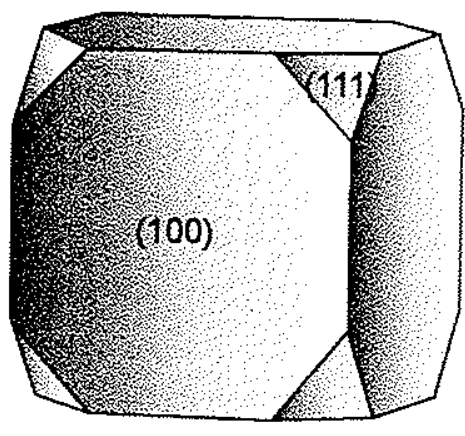

cubo + octaedro

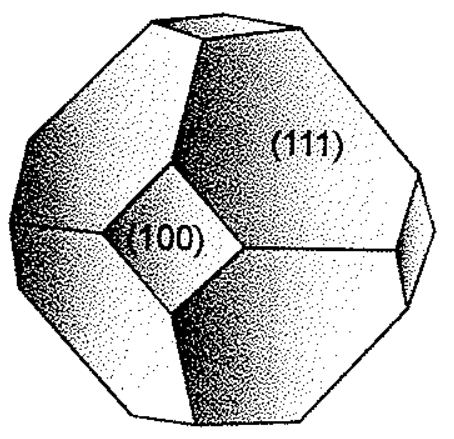

octaedro + cubo

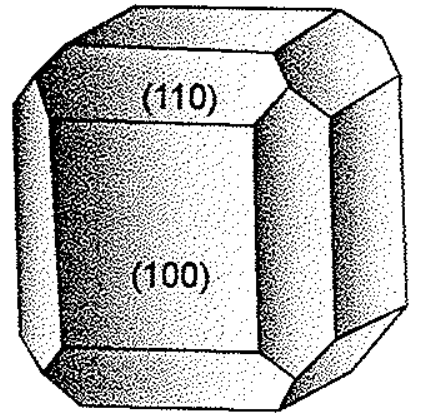

cubo + rombododecaedro

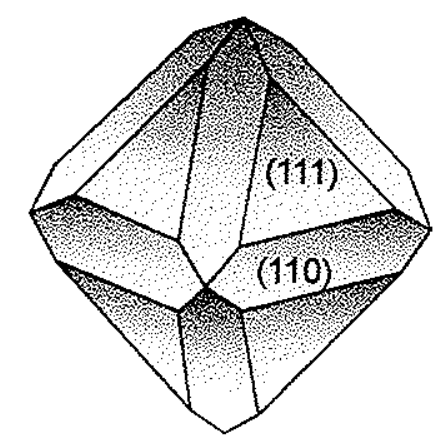

octaedro + rombododecaedro

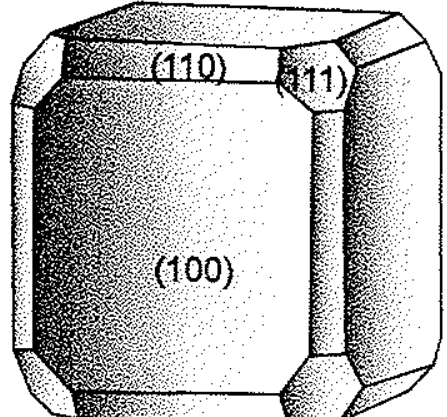

cubo + octaedro

+ rombododecaedro

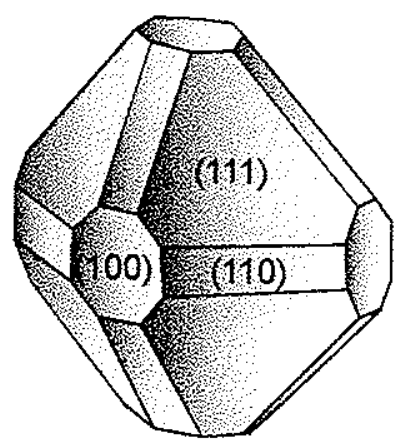

octaedro + cubo + rombododecaedro

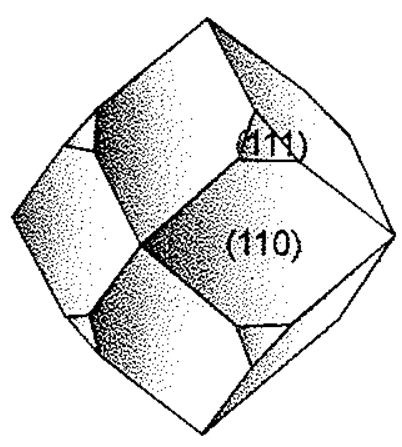

rombododecaedro

+ octaedro

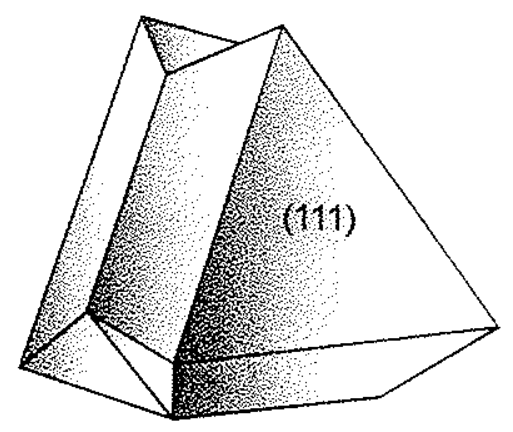

geminado de contato

Figura 5.3 - Algumas formas combinadas da classe $\mathrm{m} 3 \mathrm{~m}$ do sistema cúbico que ocorrem como formas primárias no diamante. A figura mostra também um geminado de contato que é o tipo mais comum em diamantes naturais. 
espalhamento granulométrico.

\subsection{Formas cristalográficas}

Os diamantes naturais e sintéticos exibem uma larga variedade de formas cristalográficas. Essas variações estão bem exemplificadas nas Tabelas de Formas Cristalinas de Golschimidt (1916) e na classificação mineralógica de Orlov (1977). A maior parte dos autores atuais divide as formas do diamante em dois grupos: primárias (primitivas) e secundárias (derivadas). As primárias são resultantes do crescimento cristalino, sendo representadas pelo octaedro, geminados e em menor proporção pelo cubo e rombododecaedro, todos de faces planas e arestas retas. As formas secundárias, derivadas das primárias, são todas aquelas que exibem evidências de dissolução tais como arestas e faces com grau de curvatura variado. As variações morfológicas descritas na literatura revelam que os diamantes naturais, foram submetidos a fenômenos de dissolução de intensidade variável de local para local. Tanto as formas primárias quanto as secundárias apresentam-se segundo as categorias morfológicas previstas na Tabela 2.1.

\subsubsection{Formas primárias}

Conforme já foi discutido, as formas primárias resultante dos processos de crescimento são constituídas por faces planas e arestas retilíneas, sendo representadas principalmente pelo octaedro; em menor freqüência por cubo e geminados e, mais raramente ainda pelo rombododecaedro. Entre as formas combinadas predominam as associações cubo+octaedro, cubo+rombododecaedro, octaedro+rombododecaedro e cubo+octaedro+rombododecaedro. Entre os geminados predominam sempre os de contato, sendo raras as associações complexas. Apresentase a seguir algumas considerações adicionais a respeito de cada uma das formas cristalográficas observadas no decorrer deste trabalho.

Octaedro: é a forma primária de crescimento do diamante (Mendelssohn \& Milledge 1995). A face octaédrica (111) em geral é representada por superfícies planas e isentas de irregularidade tal como está ilustrado na Eletromicrografia 5.1a que mostra um octaedro de faces e arestas perfeitamente retilíneas, constituindo um exemplar raro 


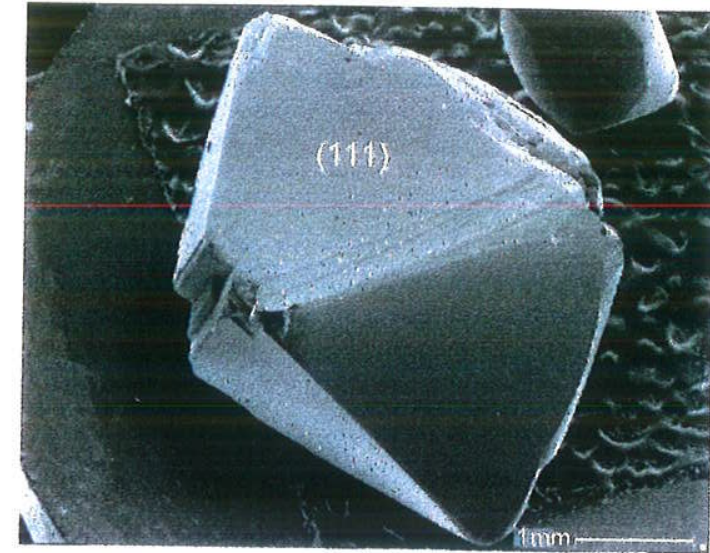

a

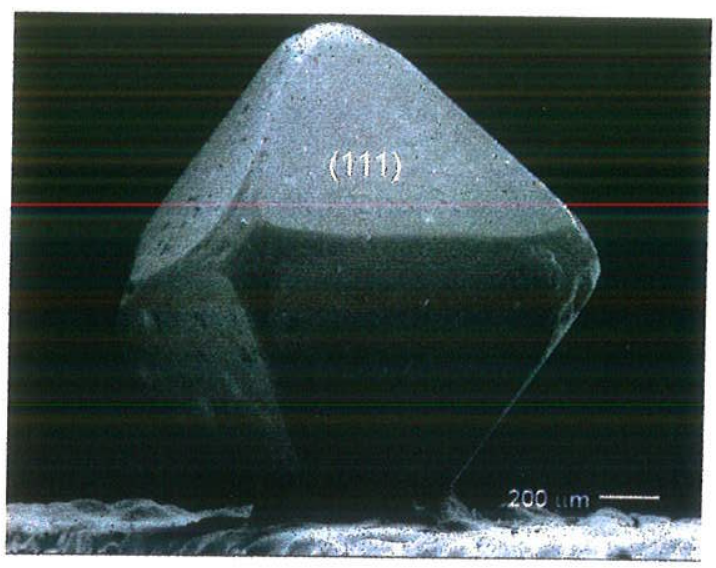

b

Eletromicrografia 5.1 - Formas cristalográficas primárias de crescimento: a) cristal octaédrico de faces planas e arestas retilíneas isento de dissolução; b) cristal octaédrico onde já é visível o início da formação de superfícies (100) e (110) devido a ação da dissolução.

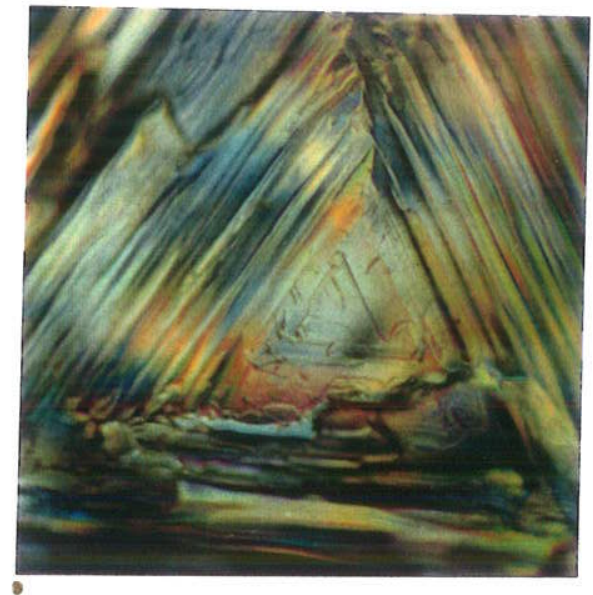

a

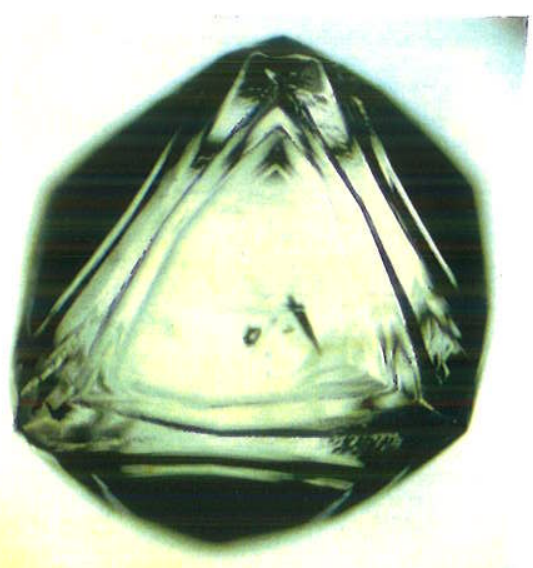

b

Fotomicrografia 5.1 - Aspectos morfológicos comuns em cristais de hábito octaédrico: a) sucessão de planos de crescimento isentos de dissolução (aumento 100x); b) cristal de hábito octaédrico tabular devido ao desenvolvimento acentuado de duas faces paralelas entre si (aumento 50x). 
nos lotes examinados. No exemplar apresentado em 5.1.b, também um octaedro de faces planas, já se observa o início da dissolução das arestas e dos vértices que irão originar as superfícies correspondentes ao rombododecaedro e cubo, respectivamente. As Fotomicrografias 5.1 exibem outras feições típicas em aumentos menores; em 5.1.a observa-se o empilhamento típico de planos de crescimento (111) e, em 5.1.b o desenvolvimento preferencial de um par de faces octaédricas paralelas originando cristais de hábito tabular. Observarse ainda que a face octaédrica exibe contorno pseudo-hexagonal devido a ação da dissolução ao longo das arestas do cristal. São visíveis também algumas trigonos, que são a feição mais característica das faces octaédricas. Algumas das características das faces octaédricas é a presença de figuras de corrosão triangulares de dimensões variadas, as quais são um dos elementos utilizados no reconhecimento das formas octaédricas, e do próprio diamante. A Fotomicrografia 5.2 reune alguns exemplos observados nos diamantes estudados: em (a) temos trígonos dos tipos piramidal $(P)$ e achatados $(F)$, notando-se que o plano octaédrico que contem os trígonos está sendo eliminados pela dissolução; a imagem (b) mostra um conjunto de trígonos piramidais entre os quais algumas estruturas exibem arestas deformadas; a foto (c) mostra trígonos do tipo $F$ com orientação contrária em relação as arestas da face octaédrica; finalmente a foto (d) apresenta trígonos em vários estágios de desenvolvimento, situadas em planos de clivagem. Esse fato constitui uma evidência importante de que os trígonos são produto de dissolução.

Cubo: trata-se de uma forma relativamente rara que se apresenta geralmente sob a forma de faces irregulares e dissolvidas, evidenciando a ação de fenômenos de dissolução pretéritos. Outra característica é o aspecto transłúcido ou mesmo opaco dos indivíduos de habito cúbico. Geralmente ocorre em combinações com outras formas da classe holoédrica. A estrutura característica das faces cúbicas são depressões piramidais de simetria quaternária. A Fotomicrografia 5.3 mostra dois exemplos típicos registrados nos diamantes estudados: na imagem (a) observa-se uma depressão quadrática isolada circundada por um padrão de ranhuras de simetria quaternária incompleta; em (b) temos um conjunto de degraus escalonados de contorno quadrado cujas características sugerem tratar-se de estruturas de crescimento. Pormenores dessas microestruturas estão evidentes na Eletromicrografia 5.2, que exibe um grande número de depressões piramidais quadráticas em diversos estágios de desenvolvimento.

Rombododecaedro: trata-se de uma forma primária extremamente rara, 


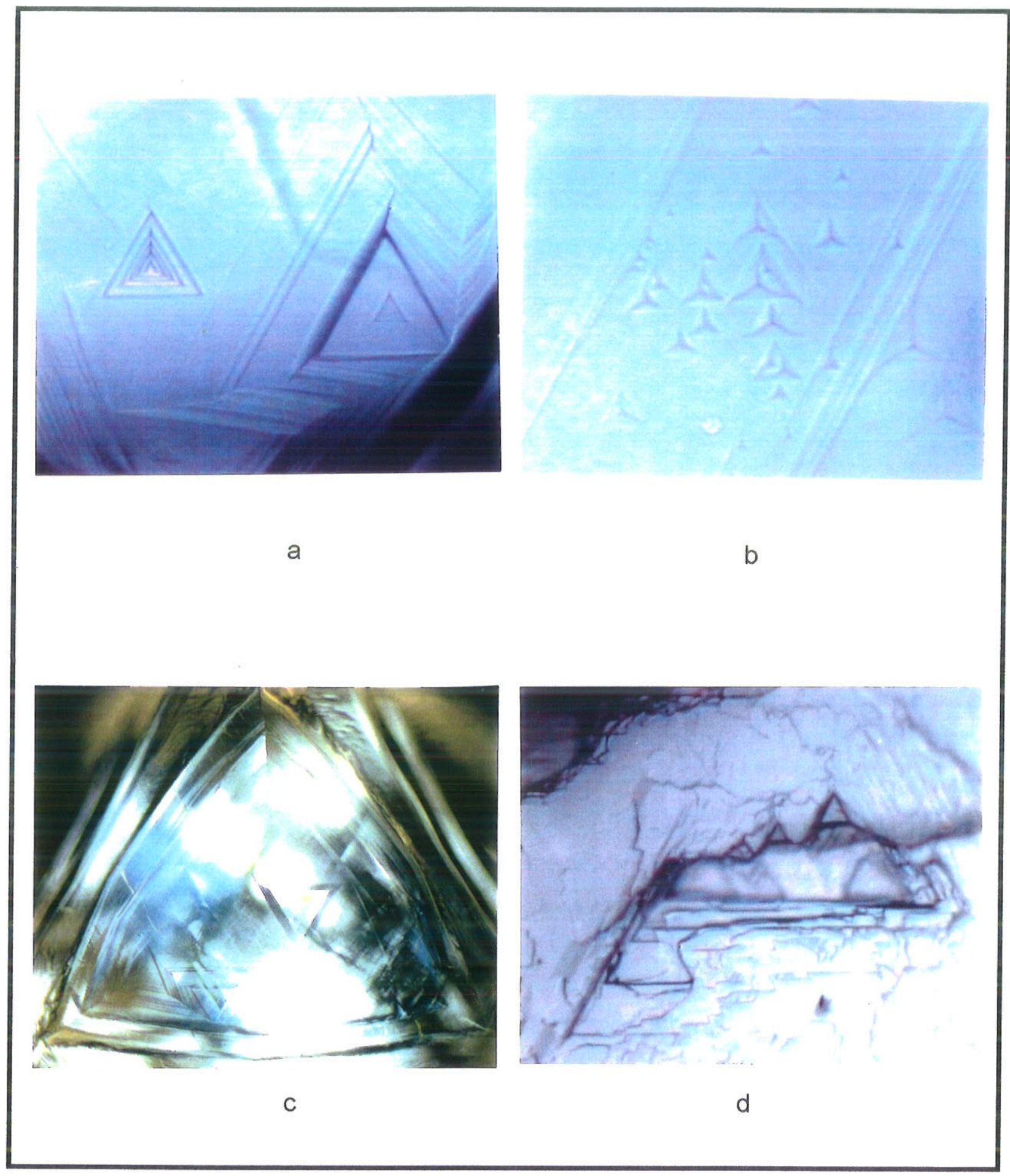

Fotomicrografia 5.2 - Microestruturas típicas de faces octaédricas: a) trígonos dos tipos P e F em um plano octaédrico limitado por superfícies dissolvidas ( aumento 200x); b) grupo de trígonos do tipo $\mathrm{P}$ de tamanhos variados exibindo deslocamentos $\mathrm{e}$ deformações nas arestas (aumento 200x); c) trígonos do tipo F exibindo a clássica orientação invertida em relação à face octaédrica (aumento 100x); d) trígonos incompletos em superfície de clivagem indicando que essas estruturas são produto de dissolução (aumento 200x). 


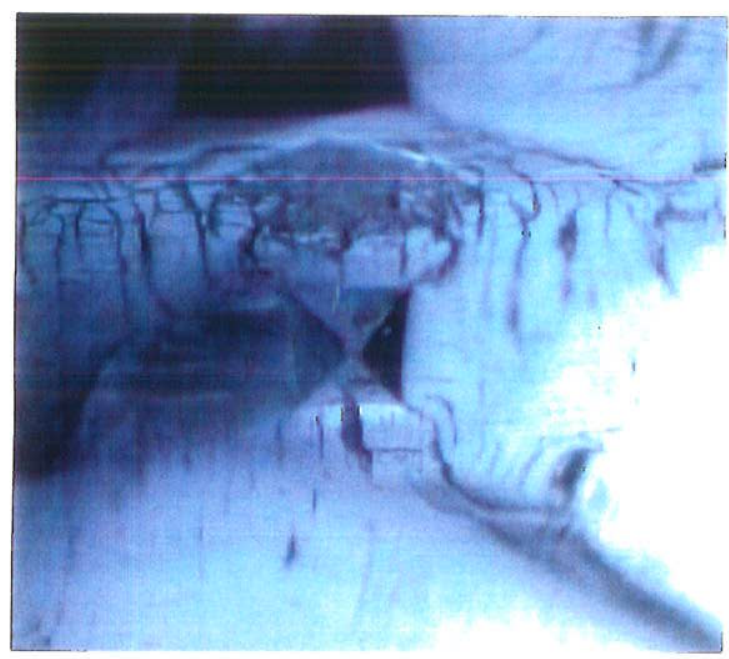

a

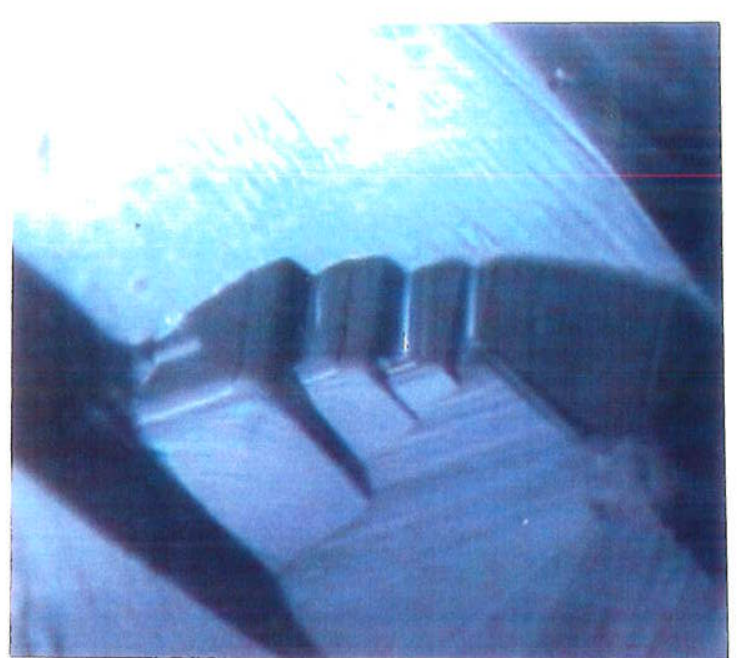

b

Fotomicrografia 5.3 - Microestruturas características de superfícies cúbicas: a) depressão quadrática isolada circundada por ranhuras; b) estruturas quadráticas escalonadas desenvolvidas entre superfícies abauladas de dissolução em uma forma combinada de rombododecaedro+cubo (aumento 200x).

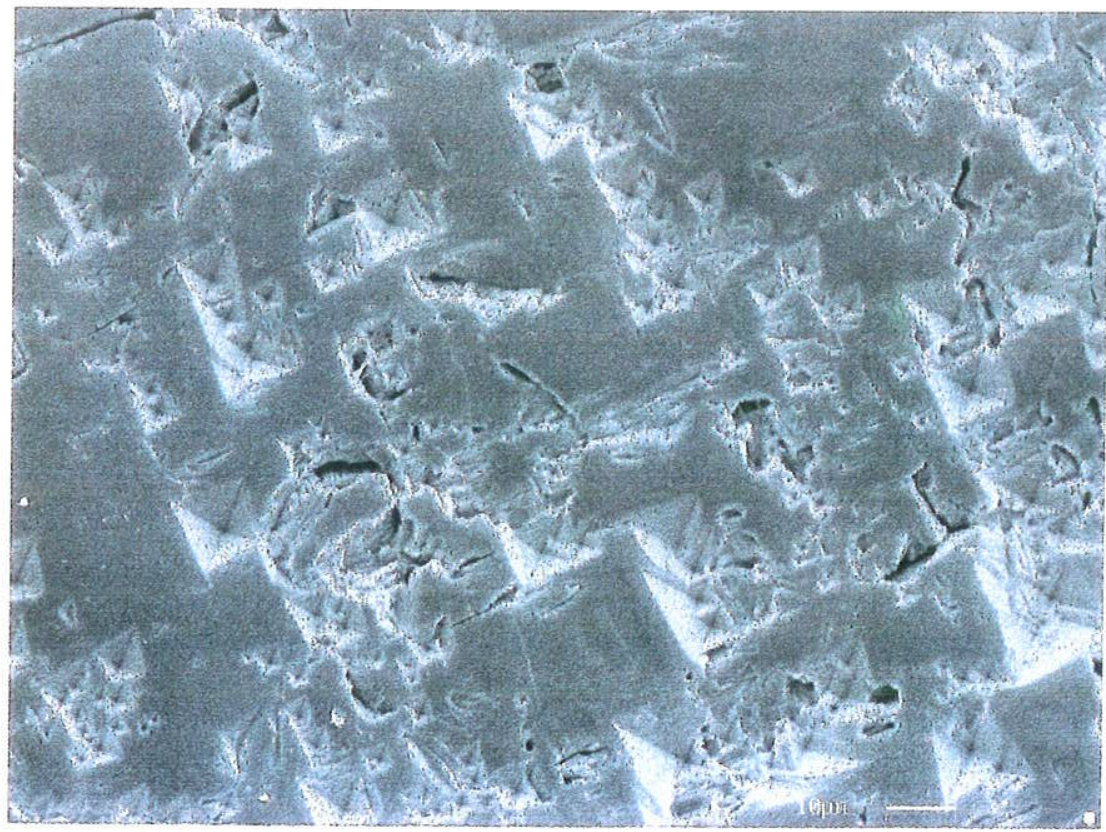

C

Eletromicrografia 5.2 - Depressões piramidais de simetria quaternária em diversos estágios de desenvolvimento. O padrão regular de algumas microestruturas contrasta com o aspecto irregular de outros setores da face cúbica. 
resultante do empilhamento sucessivo de planos octaédricos, cujo limite de desenvolvimento define as faces rombododecaédricas que nesse caso ocorre sob a forma de faces planas e arestas bem retilineas. Segundo Harris et al. (1975) e Pal'yanov et al. (1995), o desenvolvimento, desta forma ocorreria na presença de água no sistema. As superfícies rombododecaédricas exibem um grande número de microestruturas, sendo que algumas estão reunidas na Fotomicrografia 5.4. Como essas superfícies são resultantes da dissolução de faces octaédricas, a foto (a) mostra claramente degraus em vários níveis superpostos entre si; em (b) observa-se um detalhe desses degraus destacando-se o aspecto abaulado e a continuidade dos mesmos. A foto (c), ilustra um aspecto comum em cristais rombododecaédricos típicos com faces e arestas curvas, denominado estrutura em rede; por fim a imagem (d) ilustra uma microestrutura relativamente rara constituída por círculos regulares de dimensões variadas denominada micro-disco.

Formas combinadas: também constituem formas raras de crescimento entre os diamantes estudados. Os poucos exemplos observados neste trabalho estão ilustradas na Eletromicrografia 5.3. Elas incluem octaedro+cubo (a $e \quad b)$, octaedro+rombododecaedro (c), cubo+rombododecaedro (d), cubo piramidado+cubo (e). Observa-se que as combinações a e b entre cubo e octaedro, apesar de exibirem aspectos distintos, em ambos os casos as superfícies cúbicas exibem orientação negativa dispondo-se a $45^{\circ}$ em relação as emergências dos eixos cristalográficos. Merece destaque a composição entre as formas $\{100\}$ e $\{$ hko $\}$, aparentemente nunca descrita antes, e que constitui uma das provas do grau holoédrico $(\mathrm{m} 3 \mathrm{~m})$ do diamante.

Geminados: são formas primárias freqüentes tanto em depósitos detríticos quanto em kimberlitos. O tipo mais comum obedece a lei do espinélio no qual o plano de geminação é o plano octaédrico (111). Esse tipo de geminado geralmente apresenta-se sob a forma de cristais tabulares constituídos de duas faces octaédricas proeminentes e paralelas entre si, tal como ilustrado na Eletromicrografia 5.3.f. Neste caso, estão bem evidentes as características dos geminados tais como ângulos reentrantes, bem como estrias simétricas em relação ao plano de geminação. Além desse tipo de geminação que é o mais freqüente, ocorrem por sua vez geminados interpenetrados do tipo "Estrela de Davi", descritos anteriormente por Leite (1969) no Triângulo Mineiro (MG) e por Svisero (1971) na região do Alto Araguaia (MT). Segundo Harris et al. (1979), a proporção de geminados em uma dada população reflete o grau de saturação de carbono durante os estágios iniciais de crescimento. 


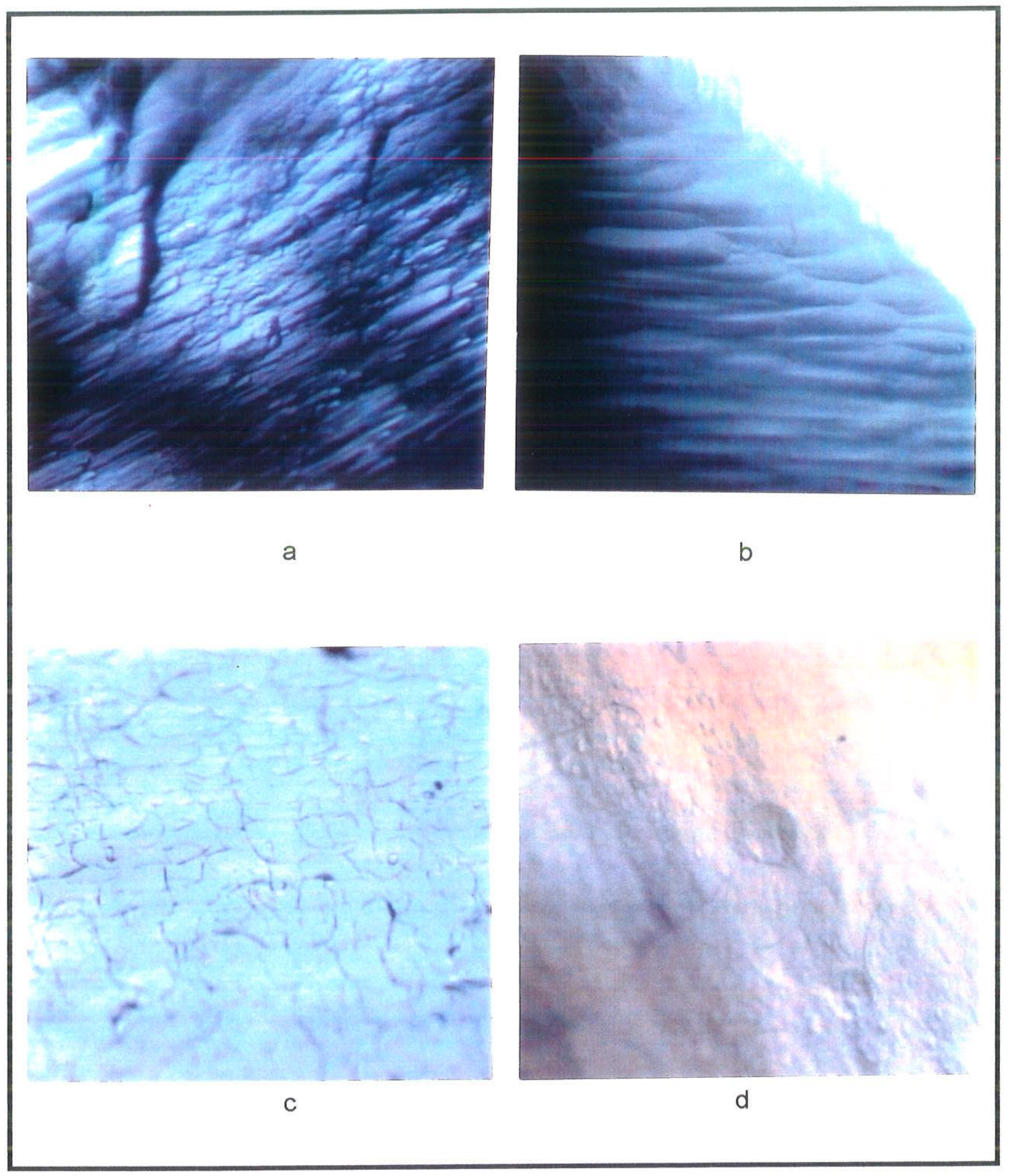

Fotomicrografia 5.4 - Outras microestruturas características observadas nos diamantes estudados: a) degraus típicos de superfícies rombododecaédricas resultantes da dissolução de faces octaédricas (aumento 100x); b) degraus alongados evidenciando um avançado estágio de dissolução (aumento 200x); c) estruturas em rede freqüentes em rombododecaedros com elevado grau de dissolução (aumento 100x); d) microdiscos em superfície rombododecaédrica (aumento 200x). 


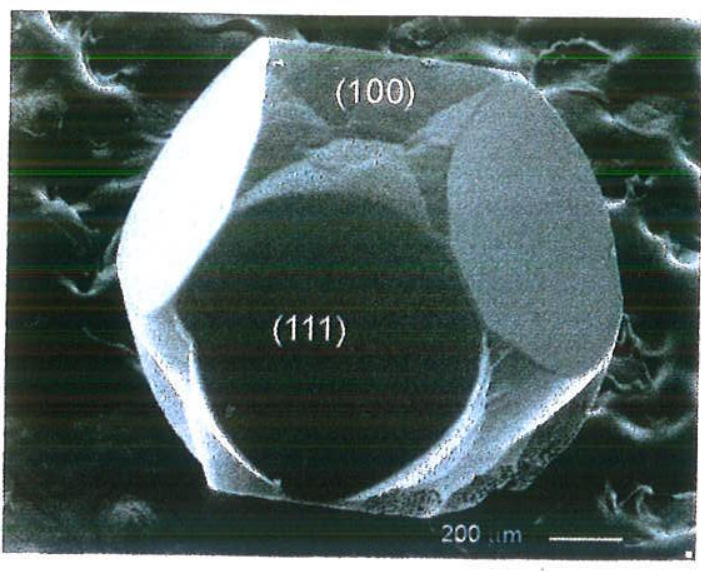

a

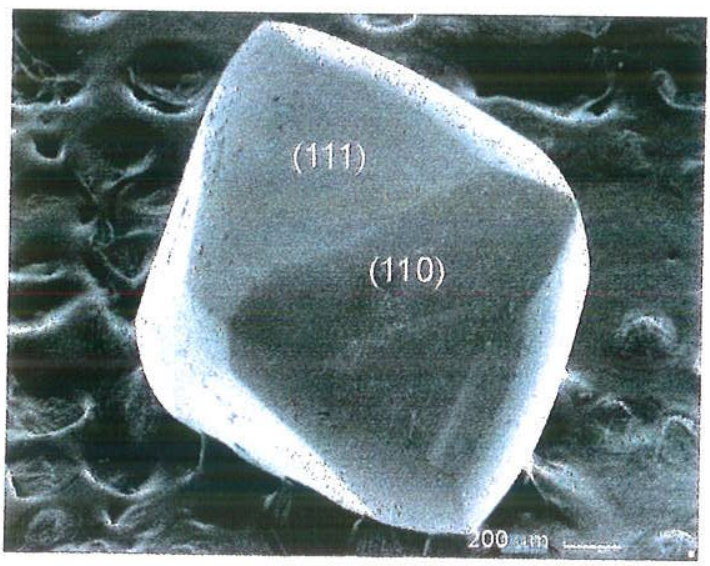

C

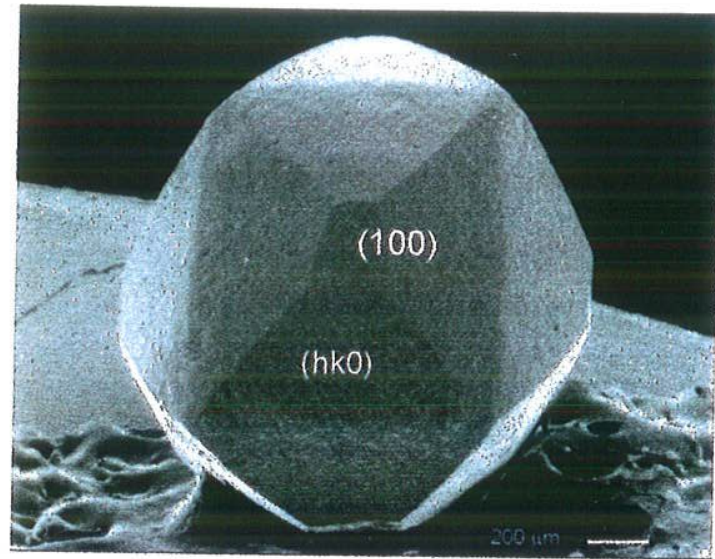

e

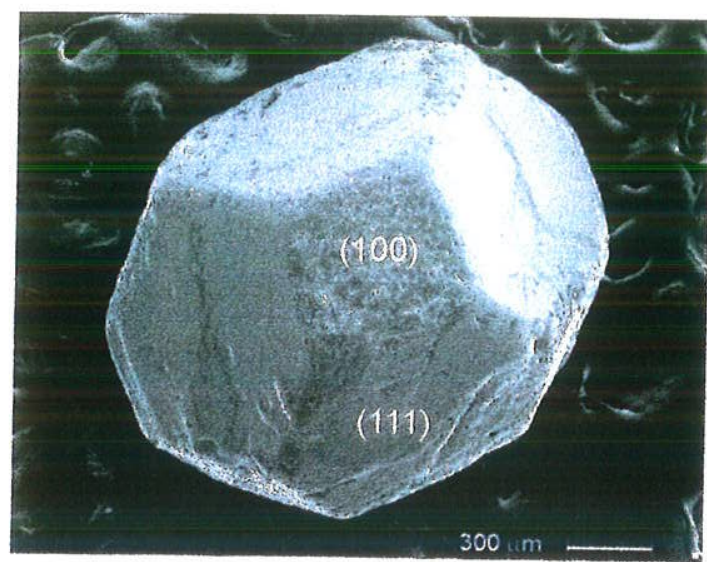

b

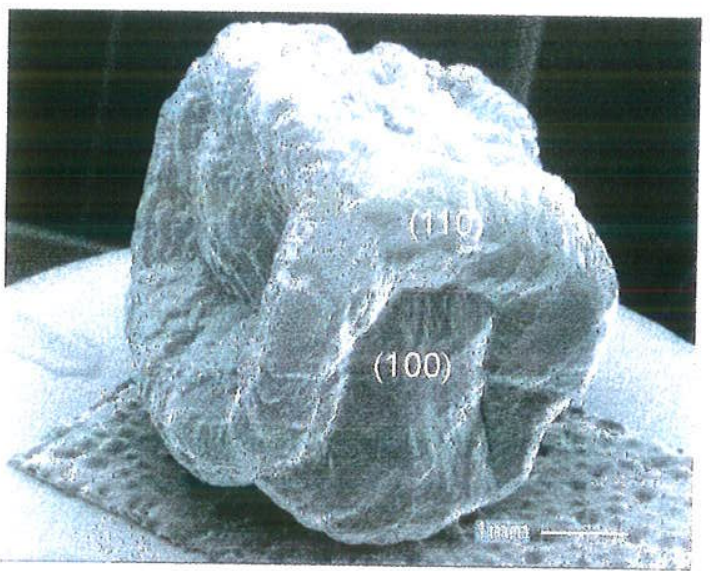

d

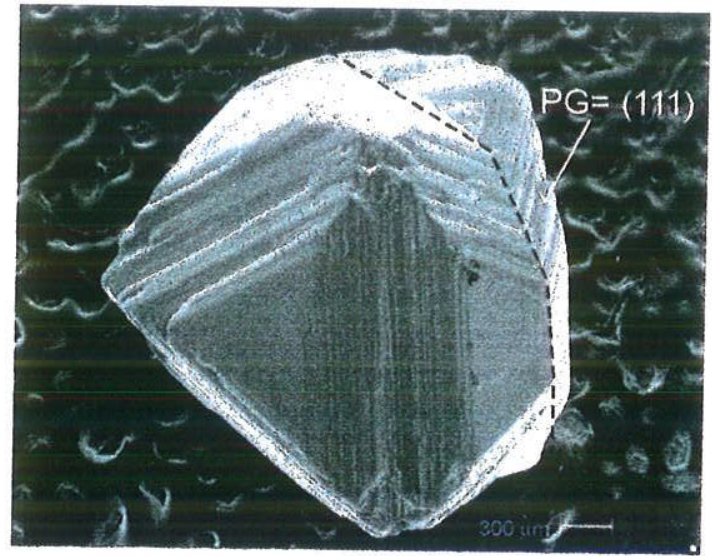

f

Eletromicrografia 5.3 - Formas combinadas resultantes do crescimento primário: a) octaedro+cubo abaulado, b) octaedro+cubo plano, c), octaedro+rombododecaedro, d) cubo+rombododecaedro com alto grau de dissolução, e) cubo piramidado+cubo, f) geminado de contato isento de dissolução. 
As demais formas simples da classe holoédrica cúbica ( $\mathrm{m} 3 \mathrm{~m}$ ) trioctaedro, icositetraedro e hexatetraedro não foram observadas entre os diamantes estudados.

\subsubsection{Formas secundárias}

Formas secundárias (derivadas) são aquelas resultantes da dissolução das formas primárias octaedro, cubo, rombododecaedro e combinaçōes entre essas formas, além de geminados, discutidos no item anterior. Nesse caso, a forma primária de crescimento, comumente a octaédrica, é modificada por fenômenos de dissolução que atuam sobre o diamante em grau de intensidades variáveis. Esses processos atuam durante a própria cristalização do diamante, ou então no decorrer do transporte do magma kimberítico através da litosfera (Orlov 1959 In: Orlov 1977, 1966; Sunagawa 1984).

O grau de reabsorção/grafitização depende da ação de vários fatores termodinâmicos tais como agentes oxidantes entre os quais destacam-se $\mathrm{O}_{2}, \mathrm{CO}_{2}$, $\mathrm{H}_{2} \mathrm{O}$, temperatura e pressão, entre outros, os quais atuaram na cristalização e/ou durante o emplacement do kimberlito (Mendelssohn \& Milledge 1995).

A principal característica das formas derivadas por dissolução é o grau variável de curvatura das faces e das arestas (Moore \& Lang 1974). Essas formas apresentam gradações variáveis entre o octaedro original, de faces planas e arestas retilíneas e o rombododecaedro de faces curvas, conforme está esquematizado no diagrama da Figura 5.4. Neste caso a dissolução modifica progressivamente o octaedro inicial de crescimento de faces e arestas retilíneas. A dissolução (corrosão) inicia-se pelas arestas e progride lentamente tendo como resultado o desenvolvimento de superfícies rombododecaédricas que terminam por suprimir completamente a face octaédrica. Ao final, obten-se um rombododecaedro de faces e arestas curvas que pode ser equidimensional (proporcionado) ou inequidimensional (desproporcionado), podendo esse último tipo ser ainda achatado ou alongado (Figura 5.4).

No caso da forma inicial de crescimento ser o cubo, o esquema de transformação está delineado na Figura 5.5. De forma análoga ao caso anterior, a dissolução atua sobre as arestas do cubo de crescimento imprimindo modificações lentas que acabam por transformá-lo em um cubo piramidado abaulado, o qual termina por evoluir para formas abauladas semelhantes ao hexatetraedro. Como esta forma 


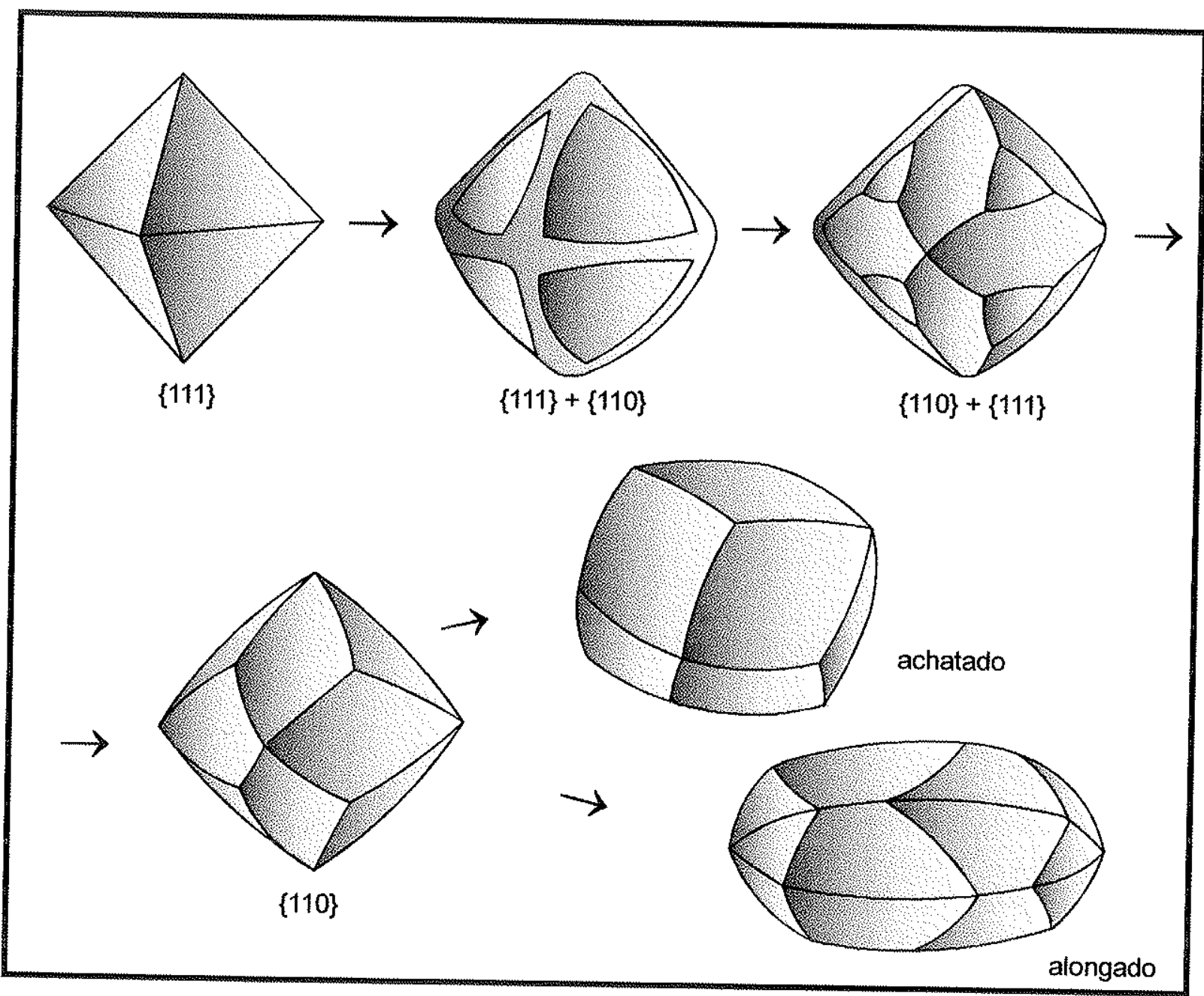

Figura 5.4 - Evolução morfológica ilustrando a transformação do diamante por fenômenos de dissolução. Nesse processo, o octaedro primário se transforma gradualmente em um rombododecaedro de faces curvas originando uma grande variedade de formas gradacionais entre os dois extremos.

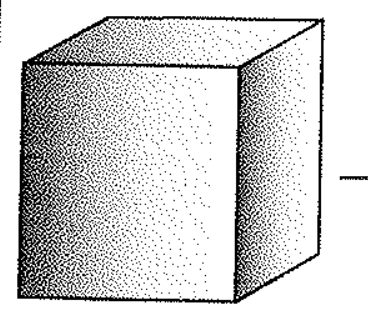

$\{100\}$

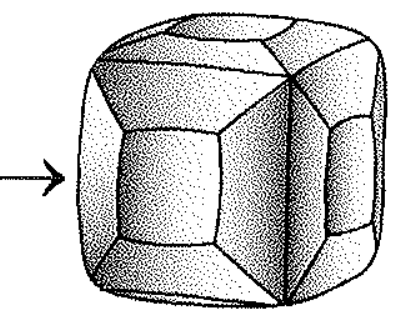

$\{100\}+\{h k 0\}$

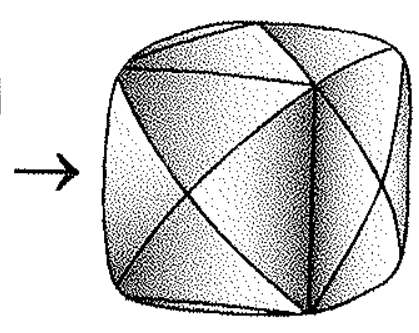

$\{h k 0\}$

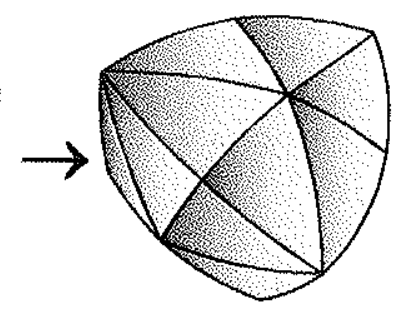

$\{h k 0\}$

Figura 5.5 - Evolução morfológica ilustrando a transformação do diamante por fenômenos de dissolução. Nesse caso, a forma cúbica primitiva se transforma gradativamente em cubo piramidado, o qual com o processo de dissolução, se torna abaulado e desproporcionado assemelhando-se a um hexatetraedro. 
cristalográfica não é compativel com o grau de simetria holoédrico $m 3 m$, adotou-se a solução proposta por Svisero (1971), o qual denominou essas formas de pseudohexatetraédricas.

Um dos problemas enfrentados no decorrer desse trabalho, foi estabelecer o padrão morfológico de cada um dos cristais examinados, tendo em vista os dois esquema de evolução apresentados. A dificuldade maior ocorreu sempre nos casos intermediários em que os cristais possuem graus variáveis de dissolução das faces octaédricas no caso do primeiro esquema. Não existe um consenso entre os autores no que diz respeito a classificação das formas intermediárias, ou seja, a partir de quando o octaedro original deixa de ser octaedro tornando-se uma forma intermediária, e sucessivamente, quando exatamente a forma intermediária torna-se um rombododecaedro. Alguns autores usam valores percentuais para efetuar essa classificação. Por exemplo, Harris et al. (1975,1979) considera como forma intermediária o octaedro que perdeu $50 \%$ da face octaédrica. Otter et al. (1994) propos uma divisão constituída de seis classes distintas, caracterizadas por valores distintos de porcentagens correspondentes a graus distintos de reabsorção.

No decorrer desse trabalho, foram seguidos de perto os procedimentos usados anteriormente por Leite (1969) e Svisero (1971). Levando em conta os critérios adotados por outros autores tais como Harris et al. (1979), Otter et al. (1994), entre outros, definimos as categorias octaedro, octarrombododecaedro (intermediário) e rombododecaedro levando em conta um grau de dissolução aproximado de $25 \%$. Assim sendo, todos os cristais com mais de $75 \%$ de faces (111) foram classificados como octaedros; os que possuíam mais do que $75 \%$ de faces (110) foram classificados como rombododecaedros; e finalmente os que possuiam valores intermediários de faces (111) e (110) foram classificados como octarrombododecaedros (transicionais).

Octarrombododecaedro: sob esse termo estão reunidas todas as formas transicionais entre $O$ octaedro de faces planas $e$ arestas retilíneas $e$ o rombododecaedro de faces e arestas curvas. A Eletromicrografia 5.4.a. ilustra um cristal intermediário típico no qual se observam duas faces octaédricas de contorno hexagonal (no sentido geométrico) remanescentes do processo de dissolução, circundadas por faces abauladas do rombododecaedro em desenvolvimento. rombododecaedro de faces e arestas curvas representa o estagio final do processo de dissolução. Sólidos desse tipo apresentam aspectos extremamente variáveis podendo ser perfeitamente proporcionados, ligeiramente desproporcionados como o exemplar 


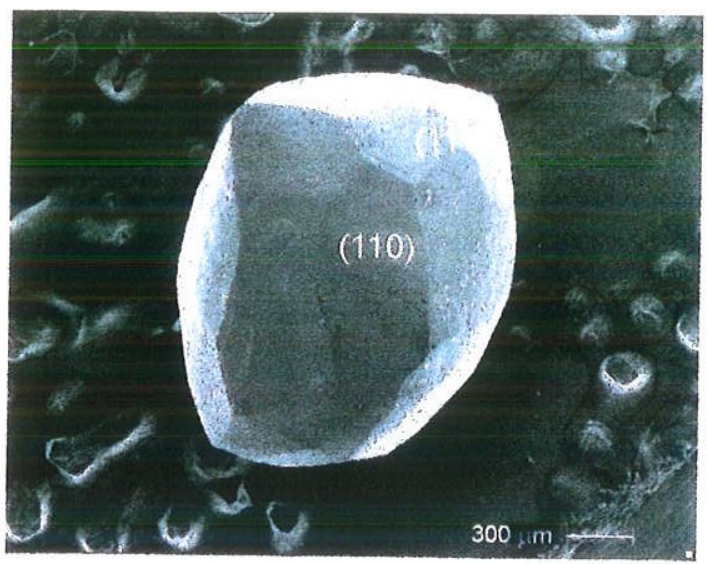

a

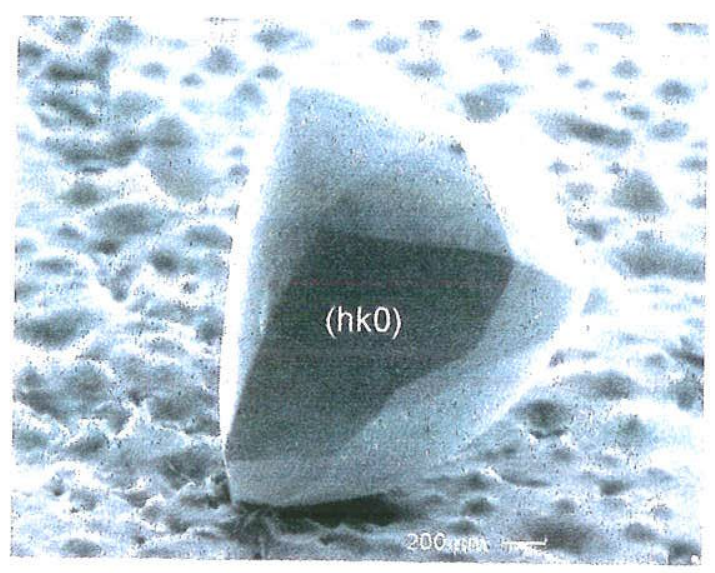

c

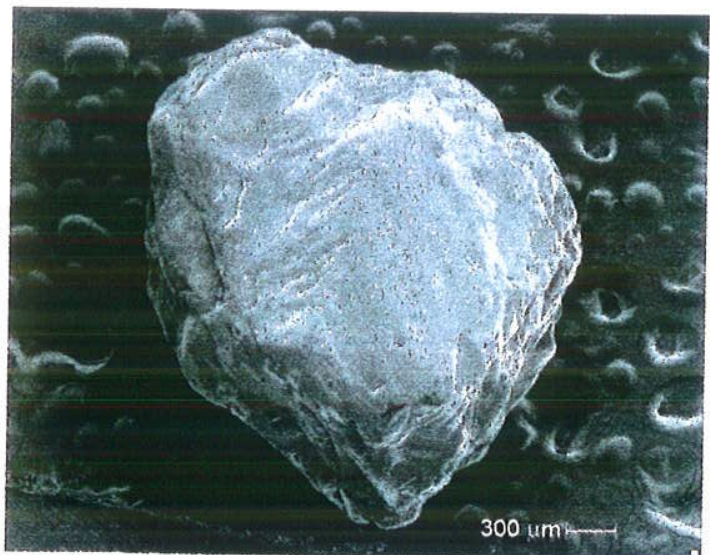

e

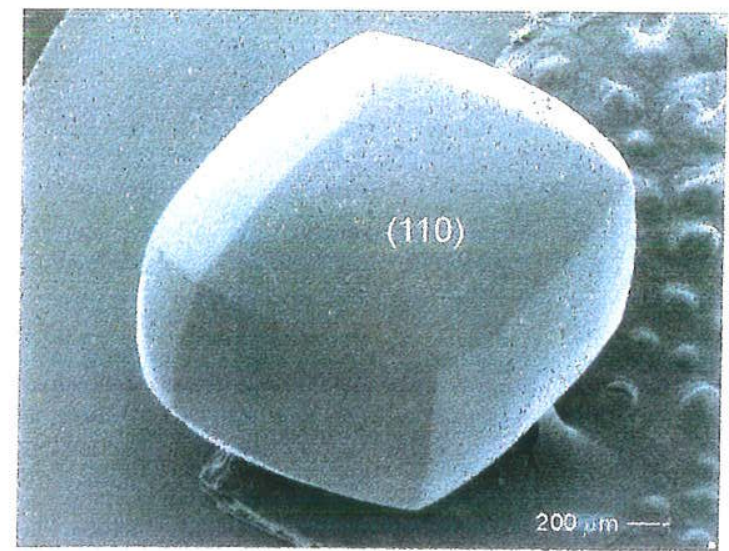

b

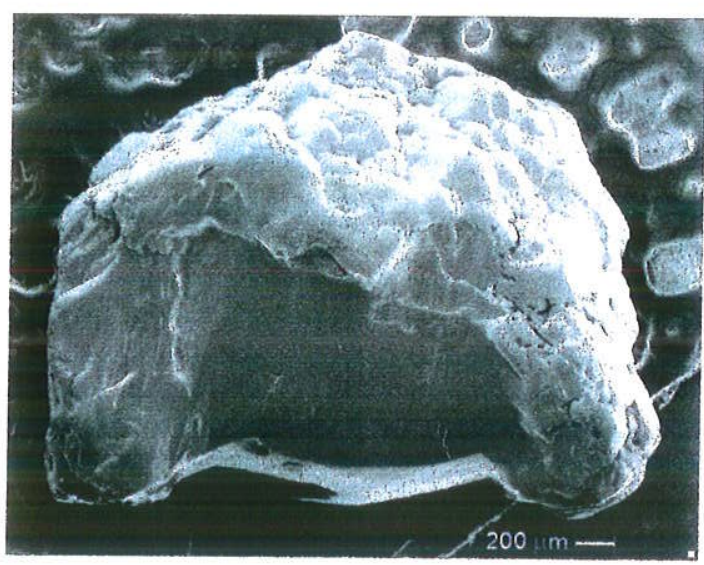

d

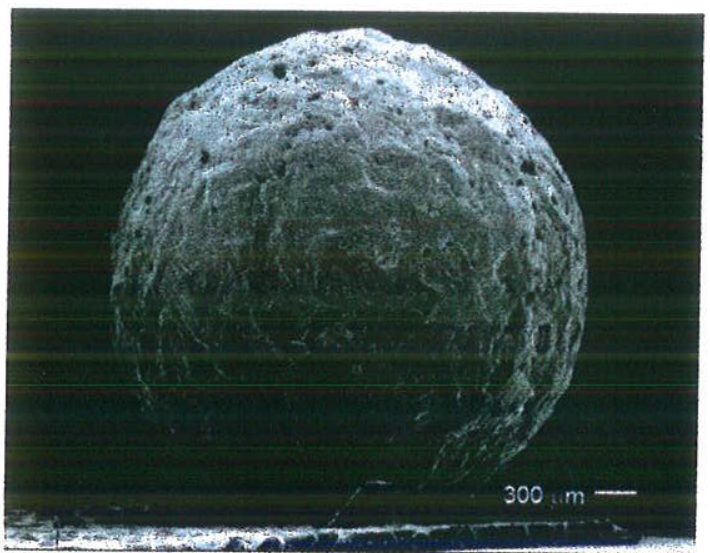

f

Eletromicrografia 5.4 - Principais formas cristalográficas interpretadas como resultantes dos fenômenos de dissolução: a) octarrombododecaedro, b) rombododecaedro c) pseudohexatetraedro, d) cristal irregular. Foram observados também nos lotes a presença de diamantes policristalinos representados por carbonado (c) e ballas (f). 
ilustrado, ou então extremamente desproporcionados. Dependendo do tipo e grau de desproporcionamento, formam-se cristais tabulares, ou então, indivíduos alongados que na linguagem garimpeira são denominados grão de arroz. No decorrer deste trabalho observamos que esta é a forma mais freqüente entre os diamantes estudados, confirmando fatos registrados em outros locais do Brasil e do mundo. A Eletromicrografia 5.4.b exibe um exemplar típico ligeiramente alongado, no qual se nota que o desproporcionamento se desenvolve segundo a direção [110].

Pseudohexatetraedro: constitui outra forma de dissolução relativamente freqüente, apresentando em geral grau de desproporcionamento variável como o exemplar ilustrado na Eletromicrografia (5.4.c). Este tipo de hábito cristalino foi considerado por Fersman e Goldschmidt (1911) como uma das evidências do caráter hemiédrico do diamante. Leite (1969) interpretou essa forma como o resultado da dissolução de um geminado de contato em que a dissolução eliminou as evidências típicas da geminação. Outra explicação proposta por Svisero (1971) admite que o cubo primitivo sofrendo fenômenos de dissolução transforme-se progressivamente em um cubo piramidado abaulado, o qual com o progredir da dissolução evolui para um pseudohexatetraedro.

Trioctaedro: forma cristalográfica desenvolvida durante a dissolução cuja freqüência é rara em todas as áreas diamantíferas conhecidas. Segundo Leite (1969), - trioctaedro resulta da dissolução de formas combinadas constituídas por cubo+octaedro+rombododecaedro. Segundo Svisero (1971), este hábito é observado em cristais intermediários entre o octaedro e o rombododecaedro, sendo apenas uma fase de transição entre o octarrombododecaedro e o rombododecaedro de faces e
arestas curvas.

\subsubsection{Outras formas}

Cristais irregulares: esse termo engloba todo tipo de cristal desprovido de morfologia ou hábito cristalino definido, tal como o exemplar ilustrado na Eletromicrografia (5.4.d). Cristais semelhantes foram interpretados por Svisero (1971) como sendo o produto de dissolução diferenciada de diamantes desproporcionados. Outra explicação é que essas formas poderiam ser resultantes da dissolução atuando sobre fragmentos de clivagem durante a fase de transporte do kimberlito. Esse tipo 
morfológico é relativamente comum como forma de dissolução, mas pode ocorrer também entre as formas primárias.

Agregados cristalinos e fragmentos de clivagem: essas duas categorias morfológicas são relativamente freqüentes e ocorrem tanto entre as formas primárias quanto entre as secundárias. Os agregados são associações em geral de dois ou três indivíduos, de qualquer uma das categorias mencionadas anteriormente. Contudo, as associações mais comuns ocorrem entre rombododecaedros e octaedros. Os fragmentos de clivagem, por sua vez, englobam diamantes de hábitos variados, nos quais a superfície de clivagem predomina sobre as demais faces do cristal. A maior parte dos autores relaciona a formação das superfícies de clivagem aos processos vulcânicos de colocação do kimberlito na crosta (Bruton 1974). Alguns autores admitem também que a clivagem possa resultar da expansão diferencial provocada por inclusões minerais, representadas inicialmente por microclivagens que evoluem para superfícies maiores (otter et al 1991). Outro fator importante responsável pela clivagem no diamante é o impacto sofrido durante o transporte após sua liberação do kimberlito pelos processos erosivos.

Policristalinos: diamantes policristalinos são agregados de cristalitos de diamantes micrométricos (10 a $100 \mu \mathrm{m}$ ), cuja origem é diferente daquela do diamante monocristalino convencional. As duas principais variedades policristalinas são o carbonado e a ballas. O carbonado é um material maciço ou porosos, opaco e de textura granular, lembrando materiais de natureza cerâmica. A coloração geralmente escura varia entre as tonalidades do preto, cinza e castanho. As dimensões são variáveis cobrindo um amplo intervalo que vai desde frações de milímetros até indivíduos com vários centímetros (Sunagawa 1984, Andrade 1999).

A variedade ballas possui estrutura esférica bem definida e a presença de cavidades e ranhuras superficiais. Apresenta dimensões variáveis em geral entre 1 e $10 \mathrm{~mm}$, brilho adamantino característico e cores variando entre cinza e castanho. Nesse caso a forma esférica é resultante da disposição de microcristais fibrosos de diamante, com comprimentos entre 30 a 40 mícrons. A origem desses materiais é um problema controvertido. Kaminskiy (1994) defendeu uma origem meteorítica para essas variedades policristalinas, entretanto, outros autores postulam que a origem desses materiais está relacionada também à rochas kimberlíticas.

Carbonados e ballas são variedades de diamante pouco freqüentes nas áreas amostradas no decorrer desse trabalho. A Eletromicrografia 5.3.e mostra um 
carbonado característico de contorno semi-hexagonal, maciço e com alguns poros na superfície. A Eletromicrografia 5.3.f, por sua vez apresenta um exemplar de ballas característico, no qual se destacam a notável esfericidade e a presença de cavidades e poros distribuídos na superfície.

\subsection{Síntese dos dados obtidos}

A Tabela 5.1 reune de forma condensada todas as informações referentes à morfologia cristalina dos diamantes estudados neste trabalho, ou seja, a distribuição dos lotes de diamante estudados, as formas cristalográficas identificadas e as suas respectivas porcentagens de ocorrência. As Figuras 5.6 e 5.7, por sua vez, mostram a distribuição das diversas categorias morfológicas reconhecidas sob a forma de diagramas de barra para facilitar a visualização e comparação dos dados referentes entre as diversas áreas estudadas. Apresenta-se a seguir algumas considerações sobre cada uma das categorias morfológicas identificadas, seguindo-se na medida do possível a freqüência dessas formas.

A forma cristalográfica dominante nos diamantes das áreas amostradas foi o rombododecaedro $\{110\}$, de faces e arestas com grau de curvatura variados. Além deste tipo, foram agrupados nesta categoria os rombododecaedros de faces planas e arestas retilíneas interpretados como forma de crescimento, bem como os rombododecaedros desproporcionados, achatados ou alongados. As porcentagens desta forma nas áreas estudadas foram as seguintes: Chapada dos Guimarães $49,78 \%$, Poxoréu 45,70\%, Paranatinga 46,76\%, Diamantino 42,28\% e Alto Paraguai $50,28 \%$. Esses valores variam dentro de um intervalo pequeno indicando que este tipo de morfologia é uma característica geral do diamante aluvionar estudado.

Fragmentos de clivagem foi a segunda categoria mais abundante em mais da metade dos lotes estudados destacando-se nos três lotes de Poxoréu, em um dos lotes de Chapada dos Guimarães, em três lotes de Alto Paraguai e nos de Diamantino e Paranatinga. A freqüência total de ocorrência total dessas áreas foi, respectivamente, Chapada dos Guimarães 9,87\%, Poxoréu 16,91\%, Paranatinga 15,03\%, Diamantino $15,3 \%$ e Alto Paraguai $14,13 \%$

As demais categorias morfológicas mostraram variações tanto entre os lotes de uma mesma área quanto em relação às áreas distintas de amostragem. Por exemplo, a 
Tabela 5.1 - Formas cristalográficas observadas em diamantes das regiões de Chapada dos Guimarães (lotes CG1, CG2 e CG3), Poxoréu (lotes Px1, Px2 e Px3), Pararanatinga (lote Pa1), Diamantino (lote Di 1) e Alto Paraguai (lotes AP 1, AP2, AP3e AP 4).

\begin{tabular}{|c|c|c|c|c|c|c|c|c|c|c|c|c|c|c|c|c|c|c|c|c|}
\hline Forma cristalina / lote & $\operatorname{co}(1)$ & $\operatorname{cG}(2)$ & $\operatorname{co}(3)$ & total & $\%$ & $P \times(1)$ & $P \times(2)$ & $P \times(3)$ & total & $\%$ & $\mathrm{~Pa}(1)$ & $\%$ & $D i(1)$ & $\%$ & $A P(1)$ & $\mathrm{AP}(2)$ & $A P(3)$ & $\mathrm{AP}(4)$ & total & $\%$ \\
\hline Octaedro & 8 & 4 & 9 & 21 & 9,01 & 37 & 40 & 28 & 105 & 7,16 & 80 & 6,71 & 16 & 5,97 & 6 & 39 & 6 & 49 & 100 & 9,61 \\
\hline Rombododecaedro & 57 & 15 & 44 & 116 & 49,78 & 140 & 182 & 348 & 670 & 45,70 & 557 & 46,76 & 116 & 42,28 & 77 & 196 & 23 & 227 & 523 & 50,28 \\
\hline Octarrombododecaedro & 4 & 2 & 8 & 14 & 6,0 & 19 & 16 & 94 & 129 & 8,8 & 211 & 17,71 & 17 & 6,34 & 0 & 11 & 7. & 30 & 48 & 4,61 \\
\hline Cubo & of & 0 & 0 & 0 & 0,0 & $\underline{0}$ & 0 & o & 0 & 0,0 & 요 & 0,0 & 0 & 0,0 & 1 & 0 & 0 & 0 & 1 & 0,09 \\
\hline Trioctaedro & 0 & 0 & 0 & 요 & 0,0 & 3 & 0 & 4 & 7 & 0,47 & a) & 0,75 & 0 & 0,0 & 0 & 1 & 0 & 2 & 3 & 0,28 \\
\hline Pseudohexatetraedro & 0 & 1 & 5 & 6 & 2,57 & 1 & 0 & 0 & 1 & 0,07 & 0 & 0,0 & 8 & 2,98 & o) & 3 & 1 & 2 & ô & 0,57 \\
\hline Cubo + Rombododecaedro & 0 & 0 & 0 & 0 & 0,0 & 0 & $1)$ & 0 & 0 & 0,07 & 1 & 0,0 & 0 & 0,0 & 0 & 요 & 0 & 0 & 0 & 0,0 \\
\hline Cubo piramidado + cubo & of & 0 & 0 & 0 & 0,0 & 1 & 0 & 0 & 1 & 0,07 & & 0,0 & 0 & 0,0 & 0 & 0 & 0 & 0 & of & 0,0 \\
\hline Octaedro+cubo & 0 & 0 & 0 & 0 & 0,0 & 0 & 1 & 0 & 1 & 0,07 & 1 & 0,08 & 0 & 0,0 & 0 & 0 & 0 & 0 & 0 & 0,0 \\
\hline Geminacio & 3 & 0 & 9 & 12 & 5,15 & 18 & 14 & 25 & 57 & 3,88 & 16 & 1,34 & 3 & 1,12 & 3 & 6 & 0 & 31 & 40 & 3,84 \\
\hline Irregular & 16 & 2 & 12 & 30 & 12,87 & 30 & 115 & 20 & 165 & 11,25 & 103 & 8,64 & 34 & 12,68 & 4 & 31 & 8 & 42 & 85 & 8,17 \\
\hline Agregado cristalino & 2 & 3. & 6. & 11 & 4,72 & 27. & 9 & 37 & 73 & 4,97 & 32 & 2,68 & 33 & 12,31 & 12 & 42 & 7 & 23 & 84 & 8,07 \\
\hline Fragmento d & 0 & 9 & 14 & 23 & 9,87 & 59 & 101 & 88 & 248 & 16,91 & 179 & 15,03 & 41 & 15,3 & 11 & 59 & 5 & 72 & 147 & 14,13 \\
\hline carbonack & of & 0 & 0 & $\underline{0}$ & 0,0 & 0 & 0 & 5 & 5 & 0,34 & 1 & 0,08 & 0 & 0,0 & of & 0 & 0 & 0 & 이 & 0,0 \\
\hline Ballas & 0 & of & 요 & 0 & 0,0 & 1 & 0 & 2 & 3 & 0,20 & 1 & 0,08 & 요 & 0,0 & 1 & 0 & 0 & 2 & 3 & 0,28 \\
\hline total & 90 & 36 & 107 & 233 & 99,97 & 336 & 479 & $651 \mid$ & 1466 & 99,96 & 1191 & 99,86 & 268 & 99,98 & 115 & 388 & 57 & 480 & 1040 & 99,93 \\
\hline
\end{tabular}



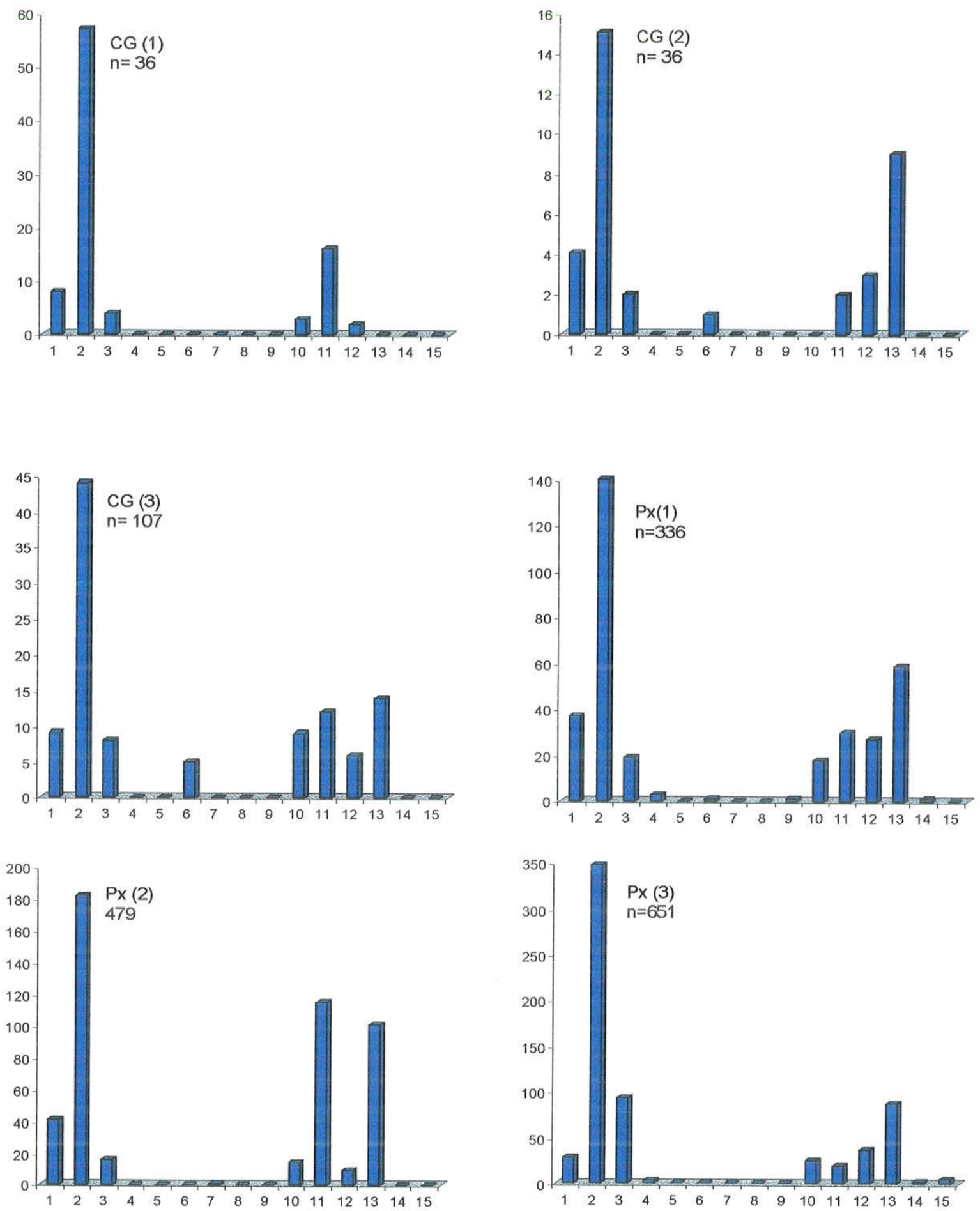

Figura - 5.6 - Distribuição do número de cristais versus a morfologia cristalina de diamantes das regiões de Chapada dos Guimarães (lotes CG1, CG2, CG3 e CG4) e de Poxoréu (lotes Px1, Px2 e Px3). Legenda: 1 - octaedro, 2 - rombododecaedro, 3 octarrombododecaedro, 4 - trioctaedro, 5 - cubo, 6 - pseudohexatetraedro, 7 - cubo + rombododecaedro, 8 - cubo + octaedro, 9 - cubo piramidado, 10 - geminado, 11 - irregular, 12 - agregado cristalino, 13 - fragmento de clivagem, 14 - ballas. 15 - carbonado. 

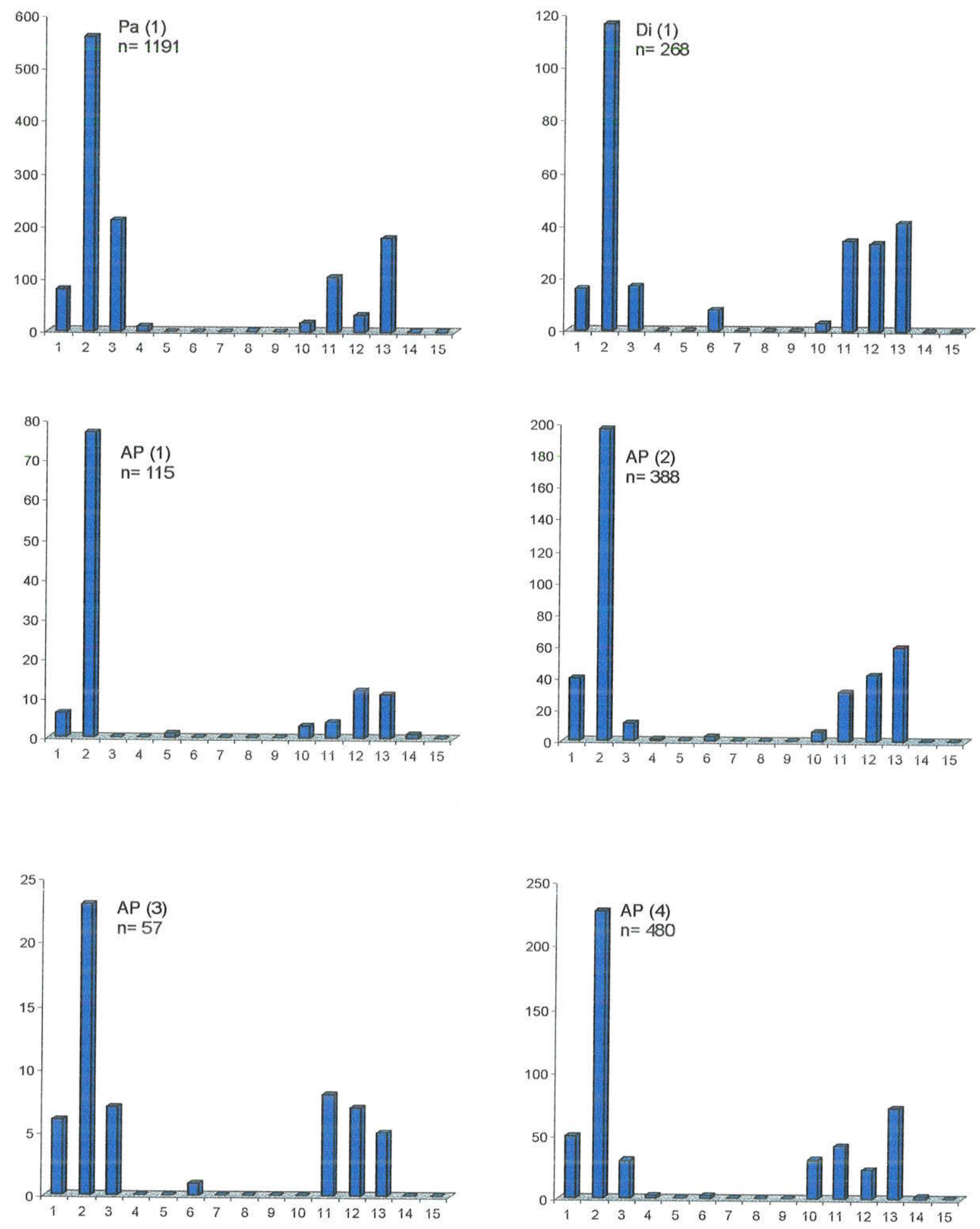

Figura - 5.7 - Distribuição do número de cristais versus a morfologia cristalina de diamantes das regiões de Paranatinga (lote Pa1), Diamantino (lote Di1) e Alto Paraguai (lotes AP1, AP2, AP3 e AP4). Legenda: 1 - octaedro, 2 - rombododecaedro, 3 octarrombododecaedro, 4 - trioctaedro, 5 - cubo, 6 - pseudohexatetraedro, 7 - cubo + rombododecaedro, 8 - cubo + octaedro, 9 - cubo piramidado, 10 - geminado, 11 - irregular, 12 - agregado cristalino, 13 - fragmento de clivagem, 14 - ballas. 15 -carbonado. 
categoria cristais irregulares (formas isentas de feições cristalográficas típicas, tais como emergência de eixos, faces e arestas bem definidas, etc.) é a segunda forma mais abundante após o rombododecaedro em um dos lotes de Poxoréu, Chapada dos Guimarães e Alto Paraguai. Nos demais lotes esta forma apresentou variações sendo suplantada por outras categorias. As porcentagens totais variaram entre 8,17 a $12,87 \%$. Os agregados cristalinos designam associações de dois a três indivíduos; nessa categoria as únicas associações observadas foram aquelas entre rombododecaedros. As porcentagens observadas em cada uma das áreas foram Chapada dos Guimarães 4,72\%, Poxoréu 4,97\%, Paranatinga 2,68\%, Diamantino $12,31 \%$ e Alto Paraguai $8,07 \%$.

Os cristais de hábito intermediário, ou octarrombododecaedros, mostraram em graus variáveis a seqüência completa de transição entre o octaedro e o rombododecaedro. Suas freqüências foram Chapada dos Guimarães 6,0\%, Poxoréu 8,8\%, Paranatinga 17,71\%, Diamantino 6,34\% e Alto Paraguai 4,61\%. A categoria octaedro, representada em sua maior parte por cristais equidimensionais, mostrou também variações de freqüência entre os lotes $e$ as áreas estudadas, tendo sido registradas as seguintes freqüências: Chapada dos Guimarães 9,01\%, Poxoréu 7,16\%, Paranatinga 6,71\%, Diamantino 5,97\% e Alto Paraguai 9,61\%. Geminados, principalmente do tipo de contato, apresentaram freqüências baixas, porém, variações significativas nas áreas amostradas, tendo sido observadas as seguintes proporções: Chapada dos Guimarães 5,15\%, Poxoréu 3,88\%, Paranatinga 1,34\%, Diamantino $1,12 \%$ e Alto Paraguai $3,84 \%$. As demais categorias morfológicas incluindo formas cúbicas, formas combinadas, pseudohexatetraedro, trioctaedro, cubo piramidado e as variedades policristalinas carbonado e ballas, foram registradas em freqüências baixas em todos os lotes estudados.

Sintetizando, a freqüência das diversas categorias morfológicas estudadas no decorrer desse trabalho foram agrupadas em: 1- Formas abundantes: rombododecaedro de dissolução, cristais irregulares, agregados cristalinos e fragmentos de clivagem; 2- Formas comuns: octaedro, octarrombododecaedros e geminados (contato e interpenetração); 3- Formas raras: trioctaedro, pseudohexatetraedro, cubo, cubo piramido, formas combinadas e diamantes policristalinos (carbonado e ballas); 4- Formas ausentes: hexaoctaedro, icositetraedro. 


\subsection{Características de outros depósitos}

\subsubsection{Complexo Kimberlítico Kao, Lesotho: Whitelock (1973) estudou} pormenorizadamente a morfologia dos diamantes que ocorrem neste complexo kimberlítico, dividindo-a em seis categorias distintas: octaedro, rombododecaedro, rombododecaedro achatado, geminado, agregado cristalino e formas irregulares. Merece destaque o fato do autor ter englobado na categoria octaedro, além dos octaedros propriamente ditos, os cristais transicionais octarrombododecaédricos, conforme está ilustrado na Figura 5.8. Neste complexo os octaedros apresentaram baixo grau de reabsorção. Além disso separou entre os rombododecaedros os achatados dos regulares, embora a diferença entre os dois tipos seja praticamente desprezível. Outro critério adotado pelo autor consistiu em reunir os cristais irregulares junto com os cristais quebrados (fragmento de clivagem) perfazendo um total de 60 a $70 \%$ dos cristais analisados.

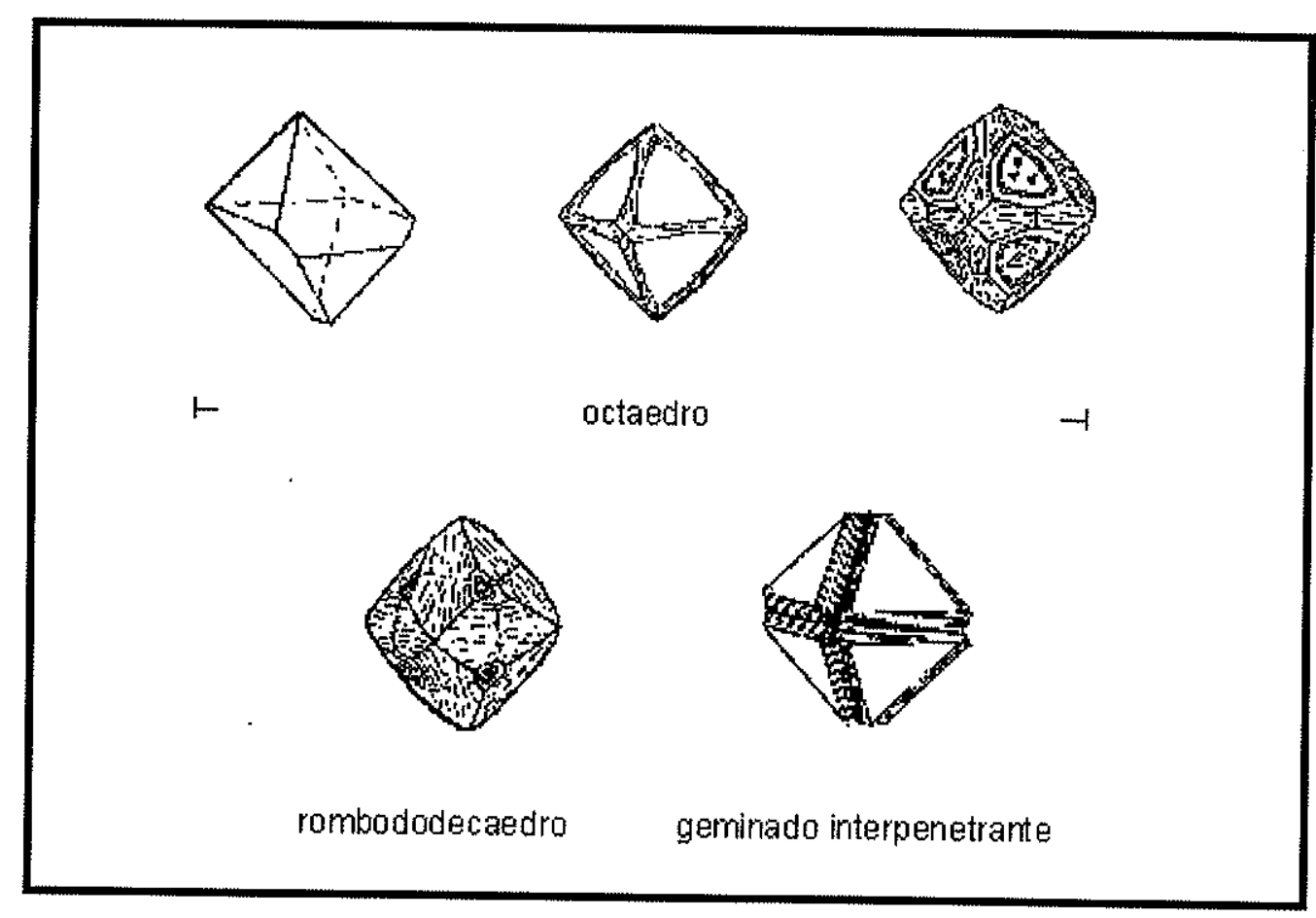

Figura 5.8 - Metodologia adotada por Whitelock (1973) na classificação dos hábitos octaédrico rombododecaédrico, aplicada aos diamantes do Kimberlito Kao, Lesotho. Notar que o autor englobou na categoria octaedro, octaedros planos e também formas transicionais octarrombododecaédricas. 
A variação morfológica do diamante do kimberlito Kao está ilustrada na Figura 5.9 , onde cada gráfico corresponde a um ponto de amostragem em uma malha regular de 16 pontos cobrindo a superfície do kimberlito, conforme já discutido no capítulo 4 . De um modo geral predomina de forma absoluta a categoria irregular seguida pelos rombododecaedros, octaedros e geminados. As demais formas apresentam variações menores e pouco significativas. Segundo esse autor, os rombododecaedros perfeitos continham linhas sinuosas desenvolvidas na diagonal das faces rômbicas, sugerindo a formação parcial de hexatetraedros. Entre os agregados, foi observado um predomínio dos rombododecaedros sobre os octaedros.

5.5.2. África do Sul: Harris et al. (1975), elaboraram uma metodologia para classificar a morfologia de diamantes de fontes primárias (Kimberlitos Premier, Finsch, Koffyfontein), bem como do depósito aluvionar Dreyer Pan, utilizando lotes constituídos por milhares de cristais. Segundo esses autores, as características físicas dos diamantes variam com o tamanho, sendo particulares e diagnósticas para cada um dos depósitos estudados. Os fatores considerados na classificação incluiram a forma cristalina, transparência, cor macroscópica, número de inclusões, características superficiais (capas opacas, grafitosas, etc.), entre outros.

O objetivo desse trabalho foi estabelecer se o diamante de uma determinada fonte poderia ser classificado quantitativamente através de suas propriedades físicas. A conclusão que os autores chegaram foi que as características físicas dos diamantes de uma determinada fonte kimberlítica são específicas. Dando continuidade a esses trabalhos, Harris et al. (1979) notaram que a morfologia dos cristais não variava com a profundidade do kimberlito.

\subsubsection{Distrito de Colorado-Wyoming, Estados Unidos da América: Diamantes do} Complexo Kimberlítico Sloan 1 e 2 foram caracterizados inicialmente por McCallum et al. (1979), os quais destacaram a transição completa do octaedro para o rombododecaedro, e a presença de rombododecaedros desproporcionados em graus variáveis. Outras formas comuns observadas foram geminados de contato, agregados de octaedros, seguidos de agregados de rombododecaedros e formas irregulares agrupadas com fragmentos de clivagem. As formas mais freqüentes observadas foram agregados cristalinos, octaedro, octarrombododecaedro, geminados e 


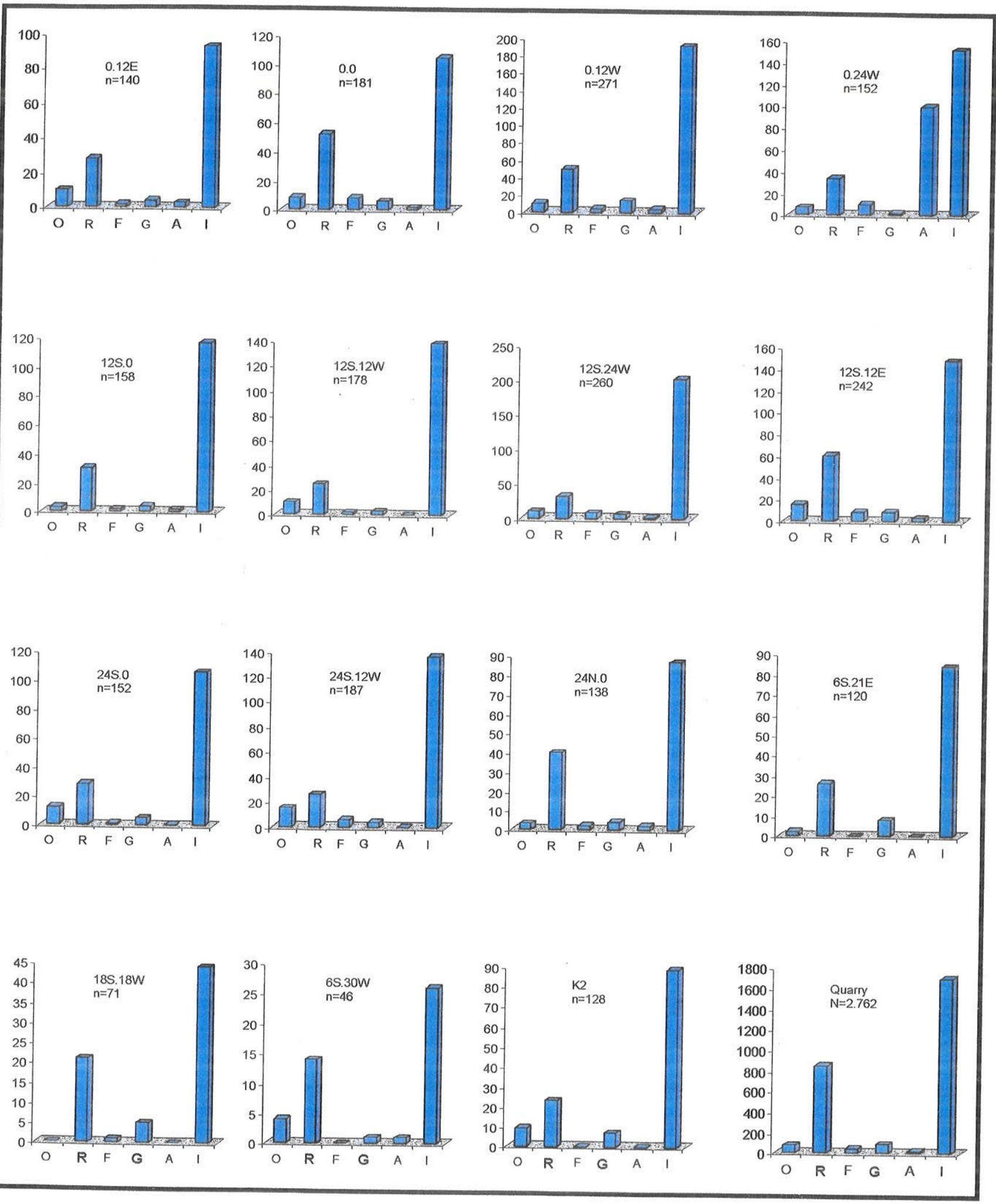

Figura 5.9 - Variações da morfologia do diamante no Complexo Kimberlítico Kao, Lesotho (Modificado de Whitelock 1973). Legenda: O - octaedro, R - rombododecaedro, F rombododecaedro achatado, G-geminados, A -agregados e I-irregulares. 
rombododecaedros (Figura 5.10). A alta porcentagem de octaedros em relação a proporção relativamente baixa de rombododecaedros sugere que a ação da dissolução foi pouco intensa neste complexo kimberlítico. Levando em conta o alto número de formas transicionais entre o octaedro e o rombododecaedro, os referidos autores concluiram que a forma original de crescimento era o octaedro de faces planas e arestas retilíneas.

Em trabalho posterior, Otter et al. (1994) apresentaram um método para classificação das propriedades físicas do diamante, no qual a morfologia foi dividida em primária, (características decorrentes da cristalização), e secundária (decorrente da reabsorção após a cristalização). Na morfologia primária foram incluídos octaedro, cubo, rombododecaedro de faces planas, cubo-octaedro, geminado, agregado de cristais pequenos $(<1 \mathrm{~mm})$ e grandes $(>1 \mathrm{~mm})$, cristais irregulares, policristalino (ballas), além de lonsdeleita (diamante hexagonal). A morfologia secundária foi classificada com base no grau de reabsorção em 5 categorias distintas, flanqueadas pelo octaedro primitivo e pelo rombododecaedro de dissolução (Figura 5.11). Esta metodologia foi aplicada a um lote de 1816 cristais do qual resultaram as seguintes características: a) predomínio destacado de cristais octaédricos nas duas intrusões, b) ocorrência pequena de agregados, irregulares e geminados, c) cristais de hábito cúbico e cúbico-octaédrico constituíram juntos apenas $2 \%$ do total das amostras (Figura 5.12). Segundo os referidos autores, os diamantes desses complexos sofreram uma perda de $25 \%$ da massa durante os processos de reabsorção. Os cristais quebrados ou fraturados resultaram da descompressão durante a erupção do magma kimberlítico devido à expansão diferencial entre as fases inclusas e o hospedeiro (diamante). Muitos cristais foram quebrados antes da reabsorção, mas não necessariamente no último estágio da corrosão, apresentando desta forma faces quebradas reabsorvidas. A ocorrência de trígonos orientados negativamente e de cavidades quadráticas, bem como a ausência de estruturas orientadas positivamente sugerem que a reabsorção ocorreu a alta temperatura $\left(>900^{\circ} \mathrm{C}\right)$, provavelmente por oxidação na presença de fluidos ricos em $\mathrm{H}_{2} \mathrm{O}$ ou $\mathrm{CO}_{2}$. 


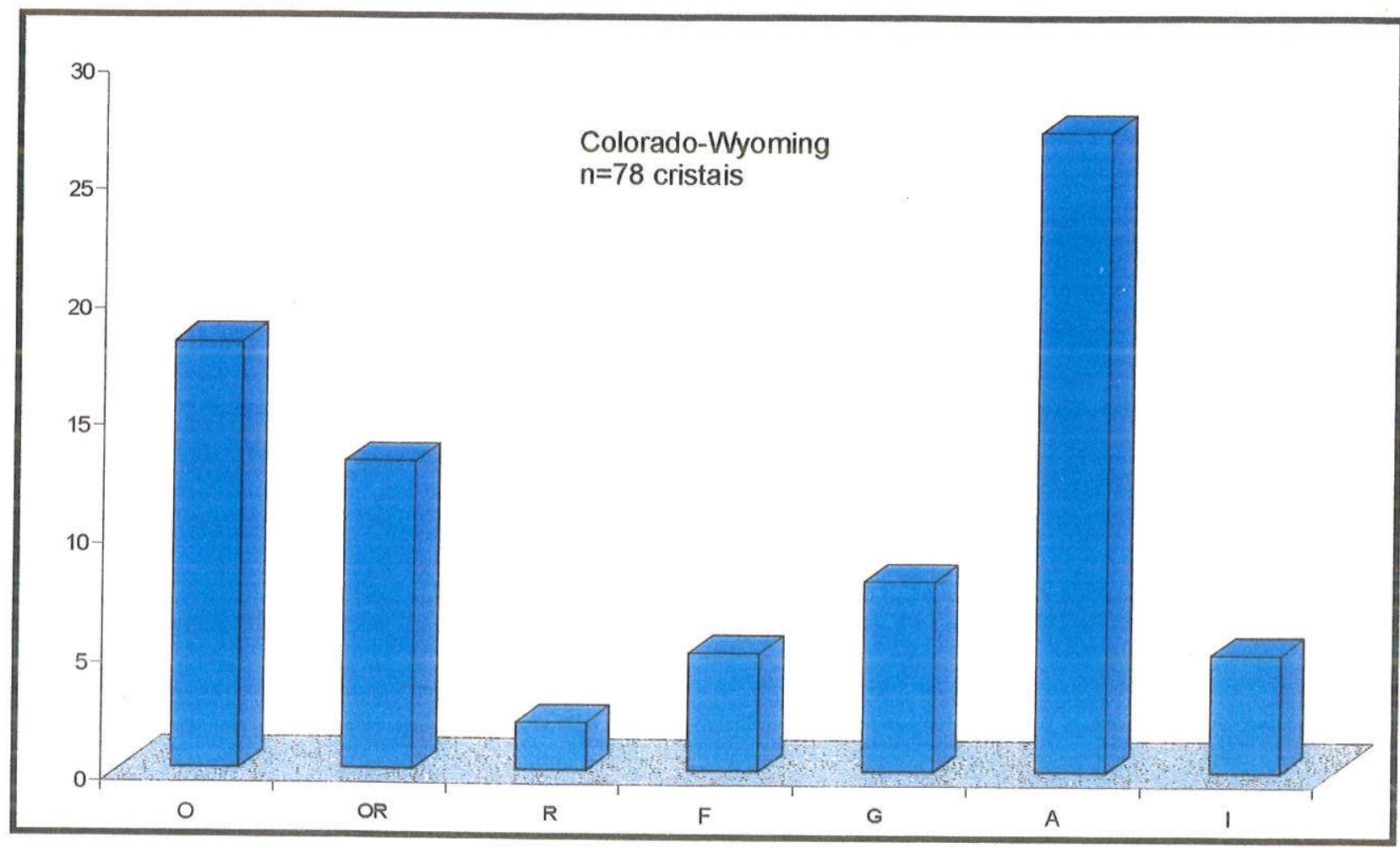

Figura 5.10 - Distribuição da morfologia em função do número de cristais de diamantes dos diatremas Sloan 1 e 2. Dados extraídos de McCallum et al. (1979). Legenda: O - octaedro, OR - octarrombododecaedro, R - rombododecaedro, F - rombododecaedro achatado, G geminado, $\mathrm{A}$-agregados e I-irregulares.

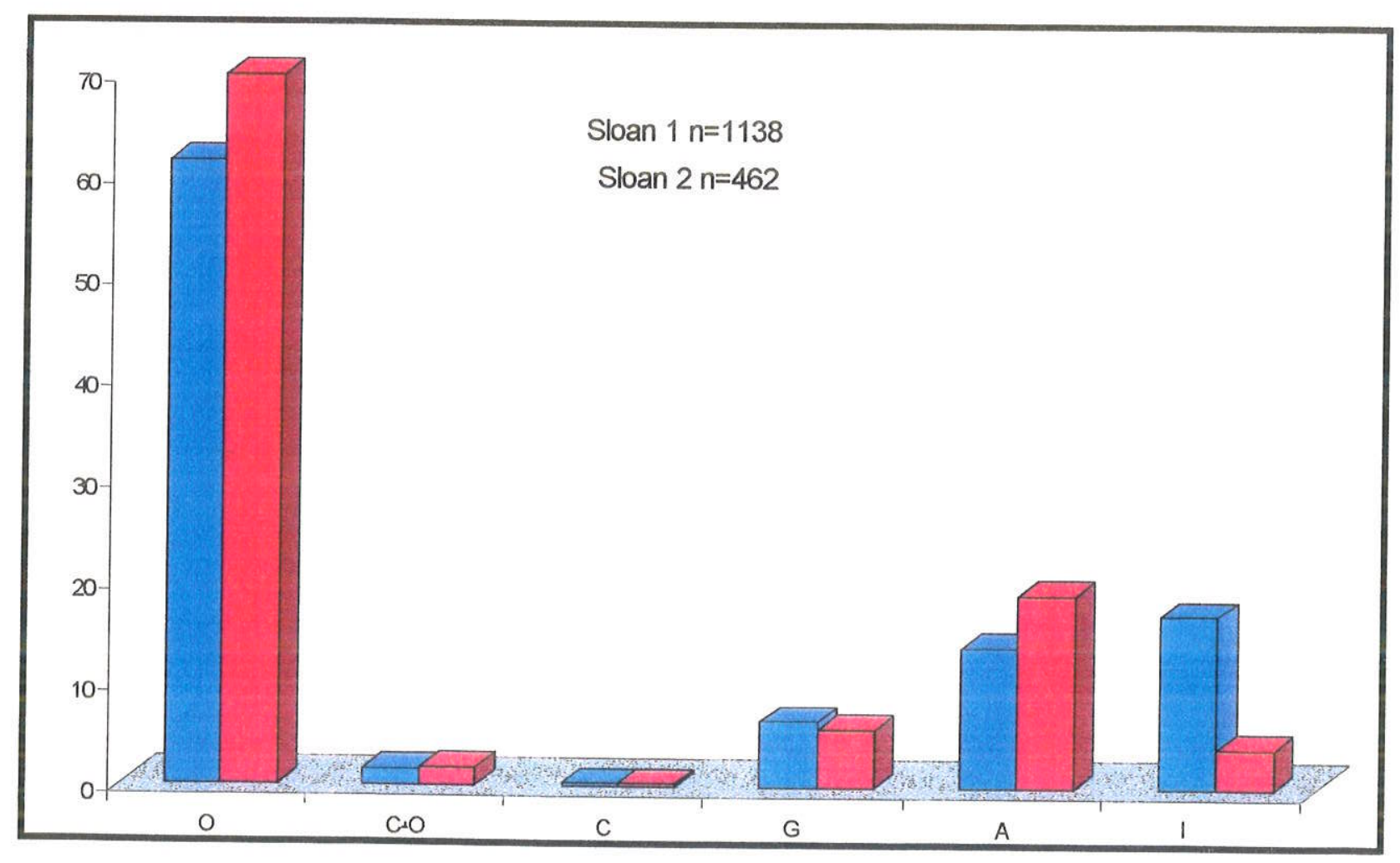

Figura 5.12 - Distribuição da morfologia versus a porcentagem de cristais de diamantes dos diatremas Sloan 1 e 2. Dados extraídos de Otter et al. (1994). Legenda: O - octaedro, C+O cubo+octaedro, C - cubo, G-geminados, A-agragados e I-irregular. 


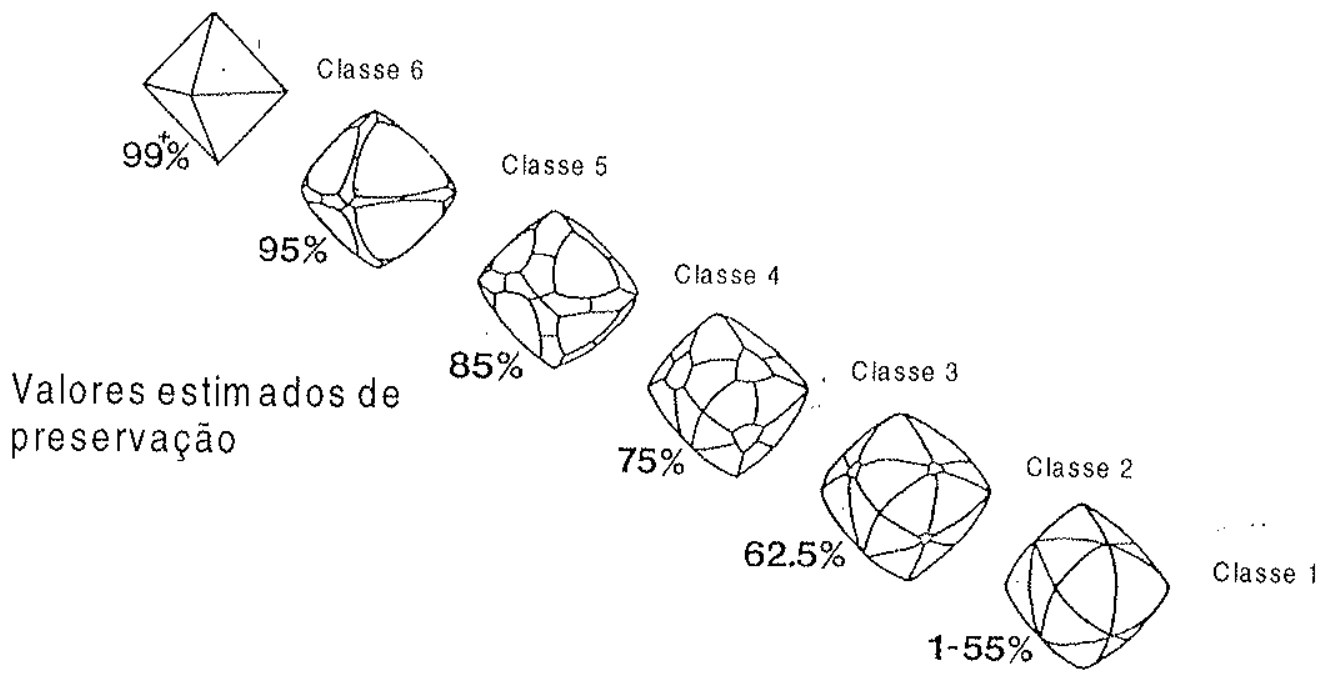

Figura 5.11 - Esquema de classificação das formas transicionais decorrentes da dissolução (Otter et al. 1994).

McCallum et al. (1994), em trabalho complementar, ampliou o número de diamantes para 112.085 cristais incluindo nessa amostragem os kimberlitos Maxwell, Autman, Schaffer, Chicken Park, Stoan 1 e 2 e George Creek 1 e 2. No entanto, foi analisada somente a morfologia de apenas 3917 cristais. Os resultados obtidos estão condensados na Figura 5.13. O octaedro foi a forma predominante na maior parte das intrusões, exceto em Chicken Park onde foi ligeiramente suplantada pelos agregados cristalinos e no corpo George Creek 1 onde os agregados são predominantes sobre as demais formas. Os agregados foram divididos em simples (constituídos de 2 a 3 cristais) e multicristalinos (compostos por mais de três cristais). Os simples predominaram no corpo Maxwell, Autman, Shaffer, Sloan 1 e 2 enquanto os multicristalinos destacaram-se em Chicken Park (35\%) e em George Creek K1 (42\%). Outro destaque é a presença da forma combinada cubo+octaedro em Autman, Schaffer, George Creek 2 e Maxwell. Os geminados, mais abundantes em George Creek K1, foram divididos nos tipos de contato e interpenetrantes, sendo o primeiro tipo mais abundante e estando presente em todos os corpos amostrados. A maior parte dos diamantes estudados mostraram em maior ou menor grau, distorções geométricas que foram consideradas como resultantes do crescimento primário. 


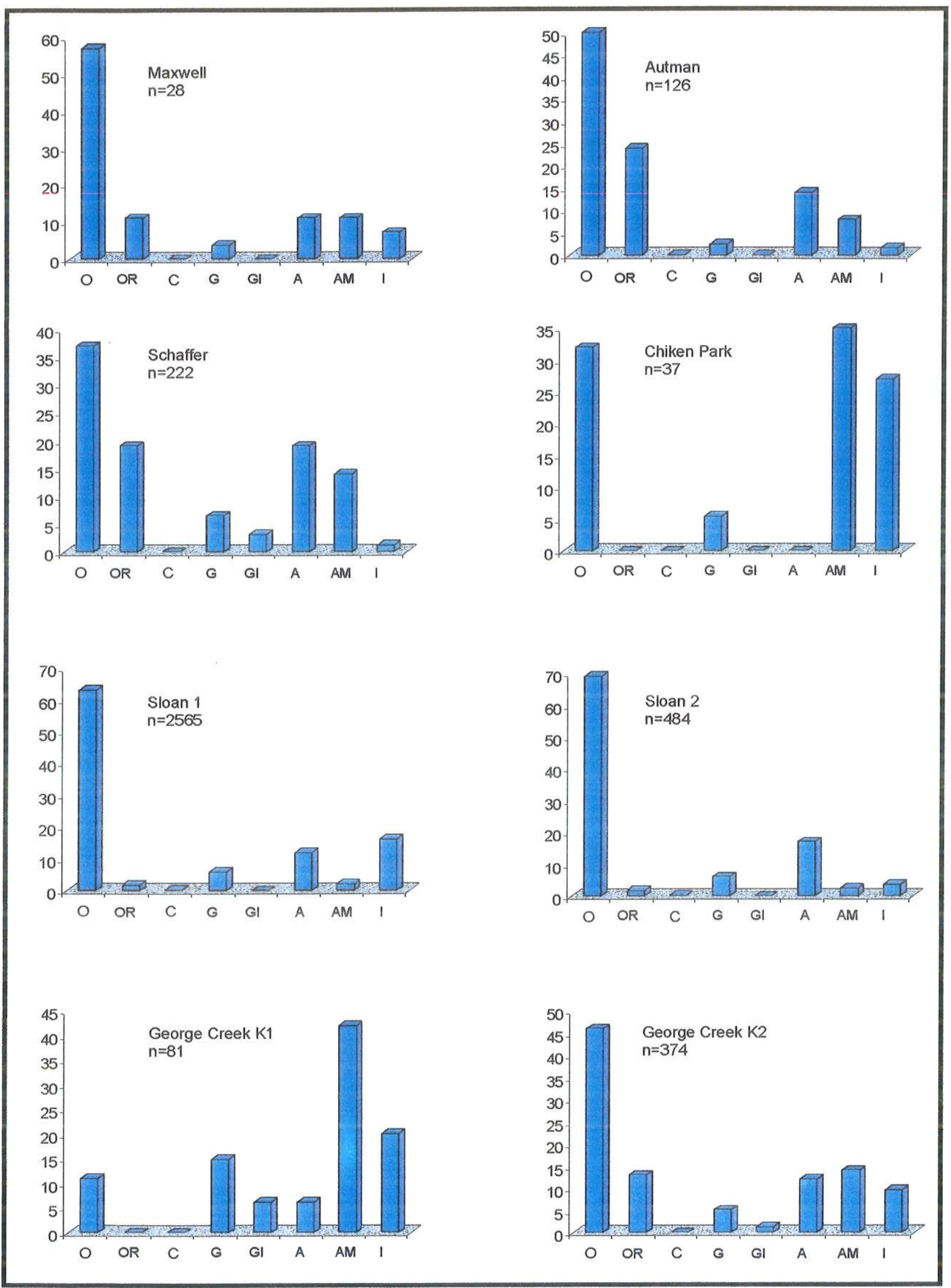

Figura 5.13 - Variação da morfologia versus a porcentagem de ocorrência de 3.917 diamantes existentes nos kimberlitos Maxwell, Autman, Schaffer, Chicken Park, George Creek1 e 2 e Sloan 1 e 2, do Complexo Kimberlítico localizados no Colorado-Wyoming. Extraido de Mccallum et al. (1994). Legenda: O - octaedro, OR - octarrombododecaedro, G - geminados, GI - geminado interpenetrante, A - agregados cristalino, AM - agregados multicristalinos e I-irreaulares. 
5.5.4. Noroeste da Austrália: Hall \& Smith (1984) estudaram a morfologia de diamantes dos Lamproítos Ellendale e Argyle, obtendo informações contrastantes com aquelas fornecidas por diamantes de kimberlitos. Por exemplo, na intrusão Ellendale os agregados, geminados e irregulares apresentaram todos hábito rombododecaédrico, o qual predomina sob os demais hábitos tais como os irregulares e os geminados de contato (Figura 5.14). Os cristais de hábito octaédrico, quase ausentes, predominaram nas classes granulométricas inferiores. Outro destaque foram os cristais constituídos por $50 \%$ de octaedro e $50 \%$ de rombododecaedro, que segundo os referidos autores representam uma segunda geração de crescimento na qual o rombododecaedro (reabsorvido) da primeira geração serviu de núcleo para o crescimento do novo octaedro. No Lamproíto Argyle, ao contrário, predominaram as formas irregulares e os geminados de contato, ocorrendo em proporções bem menores o rombododecaedro (Figura 5.14). Octaedros planos, da mesma forma que em Ellendale concentram-se nas classes granulométricas menores. Com o aumento da granulometria, diminui o número de cristais irregulares e em relação a estes, aumenta o número de agregados e de octaedros. Segundo esses autores, os diamantes desses dois corpo apresentam evidências de terem sofrido processos intensos de dissolução.

5.5.5. Rússia e Austrália: Trautman et al. (1997) realizaram um trabalho comparativo de microdiamantes entre kimberlitos de Yakútia e lamproítos da Austrália. Como está mostrado na Figura 5.15, em Yakútia predomina por ordem de freqüência, octaedro, rombododecaedro e agregado, enquanto que na Austrália, a seqüência de freqüência foi octaedro, geminado e agregado. Comparando as categorias entre sí, observou-se que o octaedro e o cubo são aproximadamente equivalentes nos dois locais e, que a diferença maior de freqüência mostrada ocorreu entre rombododecaedro, geminado e agregado cristalino. De um modo geral, os cristais apresentam alto grau de modificação da forma primária octaédrica sendo raros aqueles isentos de dissolução.

5.5.6. Lac de Gras, Canadá: Dados preliminares a respeito de diamantes do kimberlito DO-27, situado no Cráton Slave na região ártica canadense, foram apresentados recentemente por Davies et al. (1998). A morfologia desses diamantes inclui as variedades octaedro simples, formas octaédricas combinadas pouco reabsorvidas e rombododecaedros com alto grau de reabsorção. Em termos de freqüencia, os octaedros constituíram $30 \%$, os rombododecaedros $29 \%$, cubo e cubo+octaedro $12 \%$, 


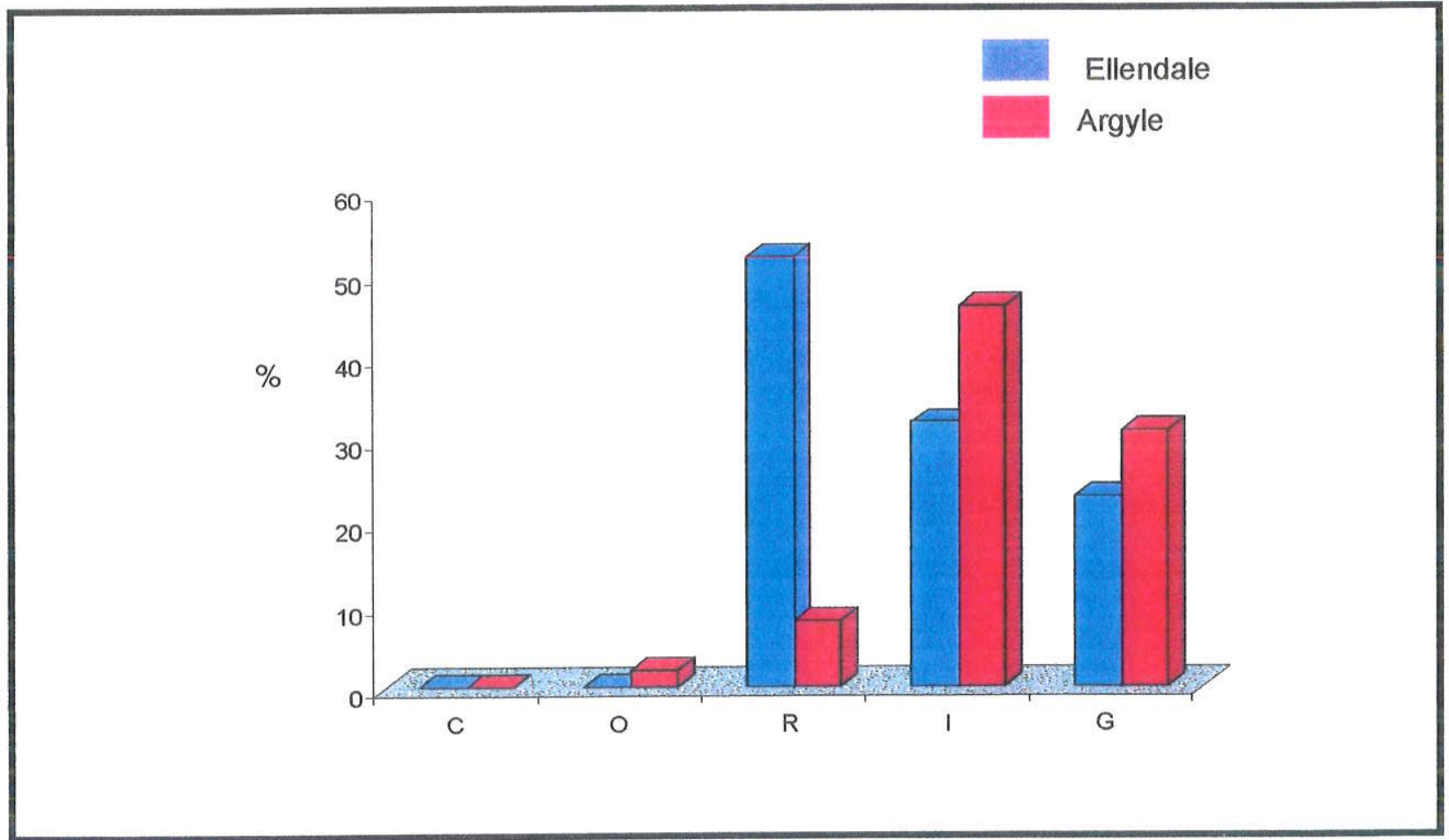

Figura 5.14 - Porcentagem versus forma cristalográfica de diamantes dos Lamproítos Ellendale e Argyle, Austrália (Extraido de Hall \& Smith 1984). Legenda: C - Cubo, O octaedro, R - rombododecaedro, I - irregular e $G$ - geminados.

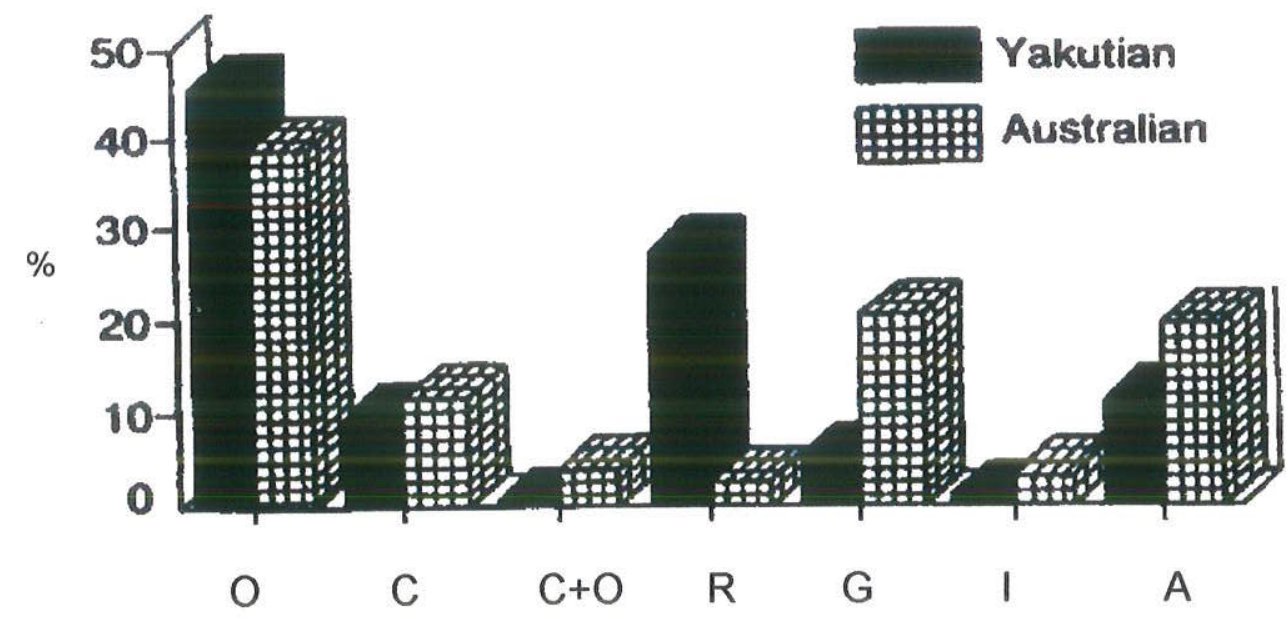

Figura 5.15 - Forma cristalina versus porcentagem de microdiamantes de Yakútia e Austrália (Extraido de Trautman et al. 1997). Legenda: O - octaedro, C - cubo, C+O cubo+octaedro, R-rombododecaedro, G-geminado, I-irregular e A -agregado. 
agregados $14,5 \%$, e fragmentos de clivagem $14,5 \%$. Segundo esses autores, a maior parte dos cristais perderam de 25 a $65 \%$ da massa original nos processos de reabsorção que atuaram sobre o kimberlito.

5.5.7. Triângulo Mineiro (MG): Leite (1969) mostrou que entre os diamantes do Triângulo Mineiro predominam as formas simples rombododecaédricas, seguidas por geminados de contato de contornos irregulares. Entre os octaedros presentes, alguns apresentaram faces arredondadas de rombododecaedros e outros, arestas e vértices reentrantes originados pelo crescimento de dois ou mais indivíduos paralelos, além de octaedros equidimensionais e tabulares. Foram observadas ainda, formas irregulares achatadas ou alongadas, e geminados de hábito tabular (Chapéu de frade), conforme mostrado na Figura 5.16. Neste trabalho os cristais rombododecaédricos foram interpretados como resultantes da dissolução do octaedro primário (primitivo).

5.5.8. Alto Río Araguaia (MT-GO): Svisero (1971) efetuou um estudo morfológico amplo dos diamantes aluvionares da Bacia Hidrográfica do Alto Araguaia, compreendendo garimpos de Mato Grosso e Goiás. Foi demonstrado nesse trabalho que o hábito rombododecaédrico predomina em todos os locais amostrados, seguindose por ordem de freqüência cristais transicionais octarrombododecaédricos, geminados de contato, agregados rombododecaédricos, formas irregulares e fragmentos de clivagem. Da mesma forma que Leite (1969), também neste trabalho os indivíduos rombododecaédricos foram interpretados a partir da dissolução de cristais octaédricos de crescimento. Além disso, Svisero (1971) interpretou as formas pseudohexatetraédricas como resultantes da dissolução de formas cúbicas primárias de crescimento.

5.5.9. Mina de Romaria (MG): Svisero et al. (1981) apresentou o primeiro trabalho específico sobre a caracterização das propriedades morfológicas e físicas baseadas em lotes com representatividade estatística. Este trabalho, baseado em um lote constituído por 5.317 cristais, confirmou o predomínio do hábito rombododecaédrico de faces curvas seguido por indivíduos transicionais entre octaedro e rombododecaedro; que a relação octaedro/ rombododecaedro $(O / R)$ varia de forma irregular reduzindo-se com o aumento da granulomeria; que a razão cubo/cubo piramidado (C/CP), da mesma forma que a anterior $\mathrm{O} / \mathrm{R}$, mostra uma redução com o aumento da granulometria. Sobre 

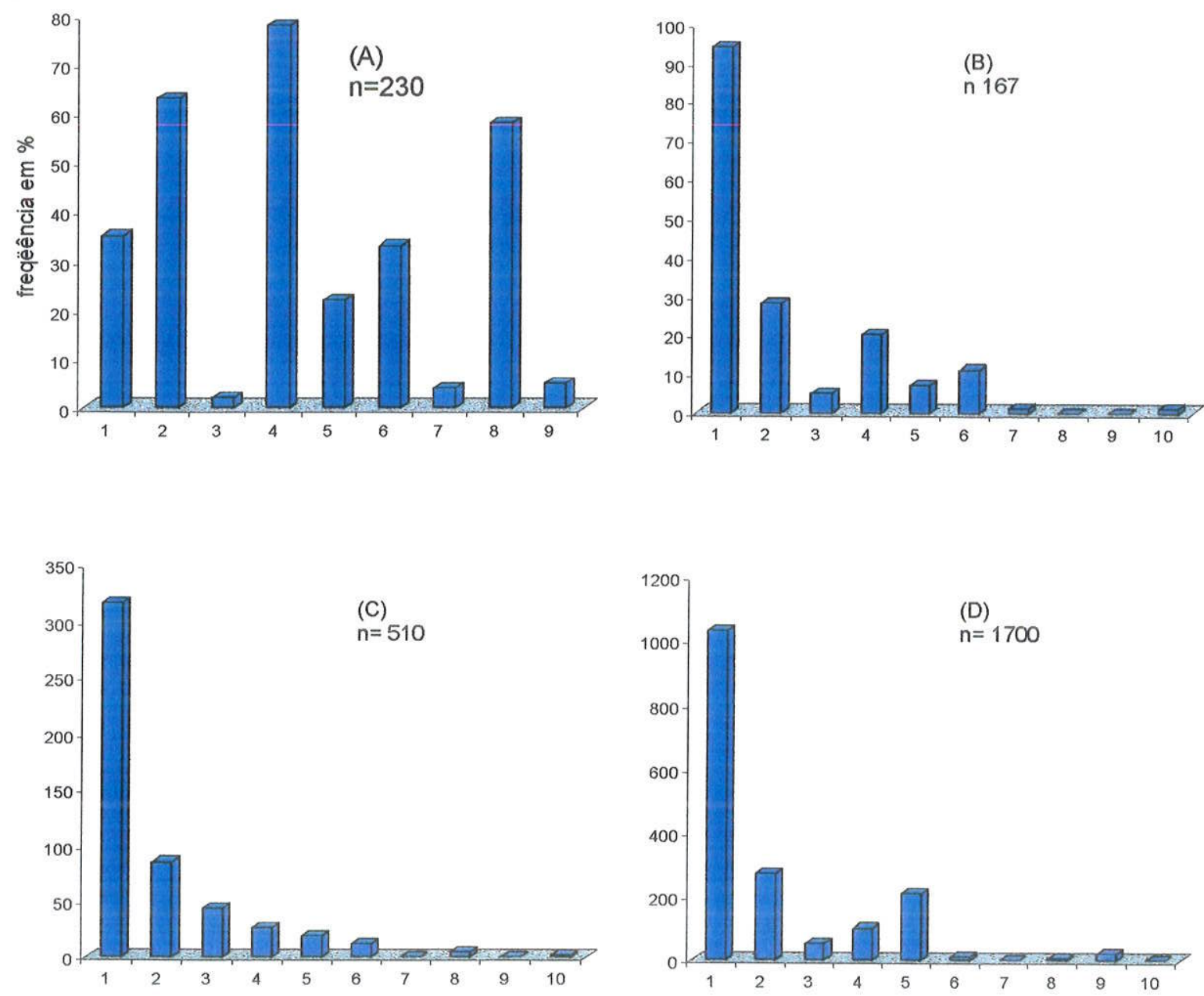

Os números das na abscissa correspondem às formas cristalográficas relacionadas abaixo. Gráficos

\section{A}

1- octaedro

2- rombododecaedro

3- cubo

4- combinado transicional

5- combinado autêntico

6- tabular

7- cubo cruzado

8- irregular

9- múltiplo

\section{B-C-D-E}

1- rombododecaedro

2- octarrombododecaedro

3- octaedro

4- fragmento de clivagem

5- irregular

6- geminados

7- ballas

8- agregados

9- cubo-piramidado

10- outros

Figura 5.16 - Características morfológicas de diamantes detríticos de algumas áreas brasileiras: A) morfologia cristalina versus a \% de freqüência na região do Triângulo Mineiro, MG (Leite 1969); B, C e D) morfologia versus o número de cristais nas regiões de Itararé-Jaguariaíva, Telêmaco Borba-Tibagi e Garimpo do Atamon, respectivamente (Chieregati 1989). 
a relação gema/indústria, Svisero \& Haralyi (1985) mostraram que na Mina de Romaria, cristais de natureza gemológica predominam sobre os do tipo indústria.

5.5.10. Tibagi (PR): Utilizando os mesmos critérios adotados por Svisero et al. (1981), Chieregati (1989) efetuou um estudo amplo sobre o diamante detrítico das regiões de Itararé-Jaguariaíva, Tomazina-Ibaiti e Telêmaco Borba-Tibagi. Nesses locais predominaram as formas rombododecaédricas, seguidas pelas formas de transição octarrombododecaédricas, ocorrendo em proporções menores octaedro, cubo piramidado, geminados e agregados policristalinos variados (Figura 5.16).

\subsubsection{Serra do Espinhaço (MG): Continuando esses trabalhos de caracterização} morfológica do diamante, Chaves (1997) tratou das ocorrências detríticas da Serra do Espinhaço em Minas Gerais, enfatizando os depósitos das regiões de Diamantina, Grão Mogol e Jequitaí. De forma análoga ao observado em outras localidades, predominaram também na Serra do Espinhaço os cristais rombododecaédricos de faces curvas e arestas abauladas, seguidos por cristais de morfologia transicional e geminados. Foram observados ainda em proporções menores formas cúbicas, fragmentos de clivagem, além de carbonado e ballas (Figura 5.17.).

5.5.12. Chapada Diamantina (BA): Estendendo os mesmos procedimentos adotados nos trabalhos anteriores para a região da Chapada Diamantina na Bahia, Andrade (1999) reuniu informações sobre as ocorrências de diamante convencional e policristalino (carbonado e ballas), garimpadas na referida região desde o início do século passado. Apesar de contar com lotes limitados em número, confirmaram-se as tendências observadas nas demais regiões, ou seja, predomínio de formas curvas resultantes de dissolução (rombododecaedros) sobre cristais de faces planas e arestas retas (octaedro, cubo e formas combinadas). Foram também descritos exemplares de carbonados com várias dezenas de quilates, além da variedade ballas que ocorre na região sob cores variadas (cinza, castanho, castanho avermelhado).

5.5.13. Serra da Canastra, Minas Gerais: Segundo Svisero \& Zolinger (em elaboração), em um lote constituído por 390 cristais provenientes da Serra da Canastra, predominaram os tipos irregulares e octaédricos sobre as demais formas. Nota-se também que os cristais de hábito octarrombododecaédrico predominaram 

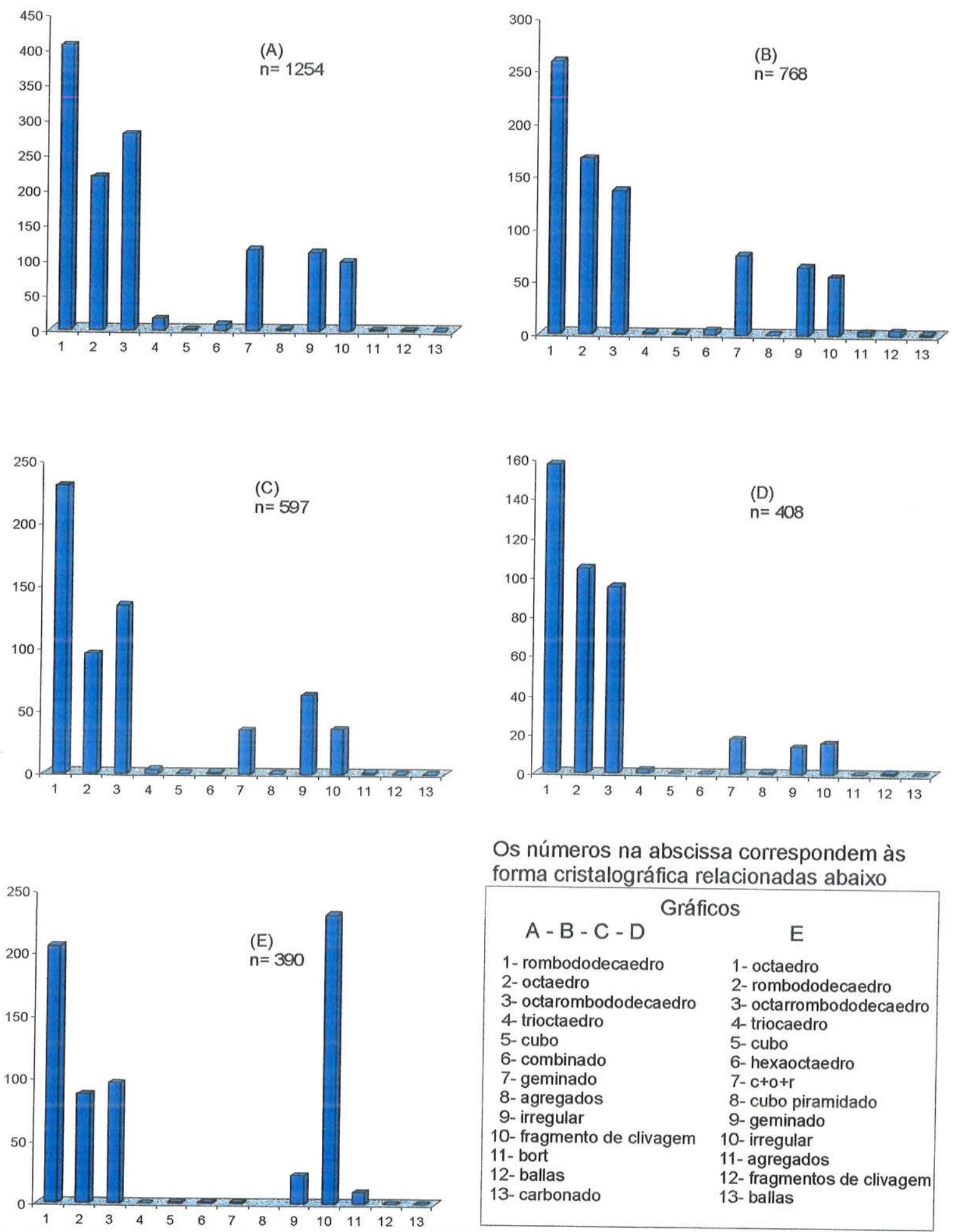

Os números na abscissa correspondem às forma cristalográfica relacionadas abaixo

\begin{tabular}{|c|c|}
\hline \multicolumn{2}{|c|}{ Gráficos } \\
\hline$A-B-C-D$ & $E$ \\
\hline 1- rombododecaedro & 1- octaedro \\
\hline 2- octaedro & 2-rombododecaedro \\
\hline 3- octarombododecaedro & 3- octarrombododecaedro \\
\hline 4 trioctaedro & 4- triocaedro \\
\hline 5- cubo & 5 - cubo \\
\hline 6- combinado & 6- hexaoctaedro \\
\hline 7- geminado & $7-c+o+r$ \\
\hline 8- agregados & 8- cubo piramidado \\
\hline 9- irregular & 9- geminado \\
\hline 10- fragmento de clivagem & 10- irregular \\
\hline 11- bort & 11 - agregados \\
\hline 12- ballas & 12- fragmentos de clivagem \\
\hline 13- carbonado & 13- ballas \\
\hline
\end{tabular}

Figura 5.17 - Morfologia cristalina versus freqüência de diamantes da região da área do Rio Jequitinhonha: A) Distrito de Diamantina, B) Distrito de Grão Mogol, C) Campos de Datas, (Distrito de Diamantina), D) Jequitaí (Serra do Cabral) todos segundo Chaves (1997); E) da Serra da Canastra, MG (Svisero \& Zolinger, em elaboração). 
sobre os rombododecaédricos, sendo os geminados pouco abundantes. Uma das características dessa área é a ocorrência de octaedros regulares (bem proporcionados), transparentes, incolores $e$ isentos de inclusões, tornando-os adequados para a lapidação do talhe brilhante (Figura 5.17).

\subsection{Discussão}

A ocorrência de determinadas formas cristalinas em kimberlitos vem sendo considerada como uma das características de cada intrusão. Como já foi mencionado, no Kimberlito Kao, Lesotho predominam de forma absoluta os cristais irregulares, seguidos de rombododecaedros e geminados (Whitelock 1973). Já nas intrusões Maxwell, Aultman, Schaffer, Chicken Park, Sloan 1 e 2 e George creek 2, Estados Unidos da América, predomina de forma clara o octaedro, seguido de agregados e irregulares em proporções bem menores (McCallum et al. 1994, Otter et al. 1994). Por outro lado, na intrusão George Creek 1 desse campo kimberlítico, predomina de forma destacada os agregados cristalinos seguidos dos irregulares e dos geminados, sendo o octaedro uma forma pouco freqüente (McCallum et al. 1991). Variações desse tipo foram observadas também nos lamproítos Ellendale e Argyle da Austrália (Hall \& Smith 1984), onde predominam rombododecaedros, seguidos de irregulares e geminados.

Após o emplacement da intrusão kimberlítica (Dawson 1980), as condições físico/químicas do meio ambiente não alteram mais as propriedades físicas do diamante a não ser que o hospedeiro esteja sujeito a eventos metamórficos posteriores. Contudo, com o tempo os processos intempéricos e erosivos desagregam a rocha hospedeira e o diamante assim como os demais constituintes minerais passa a estar sujeito às condições mecânicas do transporte.

A dureza (10) do diamante não permite que o atrito com outros minerais de dureza mais baixa tais como minerais do grupo da sílica, argilas e carbonatos entre outros, modifique sua forma durante o transporte, ou seja, não ocorre desgaste das faces e das arestas dos cristais. No entanto, devido a sua clivagem perfeita podem ocorrer fraturas internas, e também nas bordas das arestas e dos vértices principalmente de cristais com as formas geométricas menos dissolvidas tais como octaedros, cubos, formas combinadas, geminados de contato. Cabe ressaltar que indivíduos com defeitos estruturais e inclusões minerais são mais susceptíveis à 
fragmentação por impactos (Sutherland 1982). Portanto, as modificações que o cristal sofre durante o transporte afetam o seu tamanho e a categoria morfológica, aumentando a porcentagem dos fragmentos de clivagem e eliminando os cristais portadores de defeitos cristalinos.

Levando em conta esses fatos, determinadas formas são mais resistentes aos mecanismos de transporte e deposição, sendo portanto predominante na maioria dos depósitos secundários. Assim sendo, na região do Triângulo Mineiro, conforme mostrado por Leite (1969), predominam as formas transicionais octarrombododecaédricas, seguidas pelo rombododecaedro, irregulares e o octaedro. Nos garimpos da região do Alto Araguaia (Svisero 1971), o rombododecaedro é a forma predominante, fato observado também na Mina de Romaria (Svisero et al. 1981), na região do Tibagi (Chieregati 1989), Serra do Espinhaço em Minas Gerais (Chaves 1997) e Chapada Diamantina na Bahia (Andrade 1999). As demais categorias mostraram variação específicas entre os depósitos referidos.

Em linhas gerais, observou-se que os diamantes de todas as áreas estudadas apresentam um padrão morfológico relativamente semelhante, ou seja, alta proporção de rombododecaedros, fragmentos de clivagem e cristais irregulares, seguidos de agregados cristalinos, octarrombododecaedros, octaedros e geminados de contato, sendo raros cubos, combinações entre cubo, octaedro e rombododecaedro, pseudohexatetraedros e trioctaedros. A alta proporção de rombododecaedros e fragmentos de clivagem sugere que os diamantes sofreram transporte prolongado. Além disso, se levarmos em conta o espalhamento granulométrico (Capítulo 4), o que se observou foi que nas frações granulométricas maiores a freqüência foi menor, ou seja, nas regiões estudadas não ocorrem cristais muito maiores do que $4,3 \mathrm{~mm}$. Segundo Sutherland (1982), o tamanho da pedra está associado com o transporte, de tal forma que os cristais maiores são menos transportados depositando-se próximos das áreas fontes. Campos \& Gonzaga (1999), por outro lado admitem que os diamantes são pouco transportados depositando-se próximos às áreas fontes, em armadilhas geológicas. Grandes diamantes são desconhecidos nas áreas de Mato Grosso estudadas, sendo essa uma característica de outros locais tais como a região de Coromandel (Svisero 1995). 


\section{OUTRAS PROPRIEDADES FÍSICAS}

Neste capítulo serão discutidas conjuntamente outras propriedades físicas mencionadas na Tabela 2.1, destacando-se, entre outras, a cor macroscópica, a cor de fluorescência sob radiação ultravioleta, e por fim, as inclusões minerais e os defeitos cristalinos. As demais propriedades da referida tabela ainda não tratadas - absorção no infravermelho, microestruturas, catodoluminescência e razão $\delta^{13} \mathrm{C}$, ensaiadas sobretudo em trabalhos relativos à gênese do diamante, excedem os objetivos dessa dissertação e deverão ser investigados em trabalhos complementares futuros

\subsection{Cor macroscópica}

A cor é devida à absorção de certos comprimentos de onda da luz visível por uma dada substância. Por exemplo, se um diamante absorve os comprimentos de onda correspondentes ao púrpura e azul, a luz refletida por esse diamante exibirá uma combinação das demais cores do espectro visível (verde, amarelo, laranja e vermelho), de tal modo que a pedra apresentará cor amarela. Se a energia de luz incidente é suficiente para remover alguns elétrons no diamante de um certo nível de energia para outro, uma parte da energia da luz será absorvida produzindo-se um certo tipo de cor. Em diamantes perfeitos do ponto de vista químico, isto é, isentos de impurezas além do elemento carbono, seu principal constituinte químico, não ocorre absorção da luz e o cristal é incolor. Esses casos são raros, uma vez que a maior parte dos diamantes possuem sempre algum tipo de impureza química, ainda que em proporções pequenas, e conseqüentemente, exibem algum tipo de cor (Nassau 1983).

Os atributos principais da cor são o matiz, a luminosidade e a saturação. O matiz define o tipo de cor de acordo com espectro eletromagnético, ou seja, cada cor corresponde a um intervalo de comprimento de onda determinado. Luminosidade ou brilho, é a medida da quantidade de luz refletida pelo objeto colorido. A saturação representa a intensidade de uma dada cor, caracterizando a sua pureza e permitindo diferenciá-la de outra do mesmo matiz. O grau de saturação constitui uma medida da raridade de certos tipos de diamante (King et al. 1994).

Os trabalhos realizados nos últimos anos tem mostrado que a cor do diamante, ao contrário das outras gemas coloridas não está relacionada à presença de impurezas 
metálicas, em geral elementos de transição, presentes na rede cristalina (Collins 1982). Por exemplo, sabe-se que as cores do rubi (coríndon vermelho) e da esmeralda (berilo verde), embora discrepantes entre si, estão ambas relacionadas à presença de crômio na rede cristalina desses dois minerais. Outros exemplos interessantes são fornecidos pela ametista (quartzo roxo), peridoto (olivina verde) e pela rodolita (granada vermelha), nas quais a cor está relacionada à impurezas de ferro (Nassau 1976). De modo diferente ao dos exemplos citados, a cor do diamante está relacionada principalmente ao nitrogênio, a mais importante impureza química encontrada em diamantes naturais (Kaiser \& Bond 1959).

O mais puro dos diamantes contem em média $99,9 \%$ de carbono, podendo apresentar, algum tipo de impureza. Entre os elementos presentes na rede cristalina do diamante, o nitrogênio é de longe o mais importante constituindo a base para a classificação espectroscópica deste mineral nos Tipos I e II (Robertson et al. 1934). Diamantes do Tipo I possuem nitrogênio e representam cerca de $98 \%$ do total de diamantes. Nesse grupo o nitrogênio pode se apresentar sob a forma de plaquetas paralelas a (100) constituindo o subtipo la, ou então substituindo átomos de carbono na rede cristalina formando o sub tipo lb. Essa segunda variedade é rara abrangendo menos de $2 \%$ dos diamantes. Dependendo do estado de agregação do nitrogênio registrado no espectro infravermelho, são utilizadas as subdivisões laA, laB e o tipo intermediário laAB (Bursill \& Glaisher 1985; Mendelssohn \&. Milledge 1995). Diamantes do Tipo II são desprovidos de nitrogênio e podem ser subdivididos com base em sua condutividade elétrica. Um primeiro grupo denominado Tipo lla reune diamantes não condutores que são a maior parte desse grupo. O segundo subgrupo denominado Tipo Ilb possui boro na estrutura e são semicondutores (Harris 1987). Além dessas impurezas ocorrem uma série de outros elementos químicos muitos dos quais estão relacionados à fases minerais de naturezas diversas, inclusas no diamante (Meyer 1987), que serão abordadas posteriormente. Wilks \& Wilks (1994) classificou as impurezas químicas do diamante em três grupos: a) $\mathrm{N}, \mathrm{H}, \mathrm{O}$, e $\mathrm{S}$, presentes em concentrações entre 1 e 1.000 ppm em peso, b) B, Mg, Al, Si, Ca, V, Cr, Mn, Fe, Co, $\mathrm{Ni}, \mathrm{Cu}, \mathrm{Ag}$ e $\mathrm{Ba}$, em teores entre 0,1 a $100 \mathrm{ppm}$, e finalmente, c) outros elementos menores variados em concentrações situadas entre $10^{-6}$ a $10^{-1} \mathrm{ppm}$.

Apesar do diamante incolor ser o mais freqüente, esse mineral ocorre em todas as tonalidades das cores constituintes do espectro luminoso. Os diamantes com alto grau de saturação constituem um grupo especial conhecido sob a denominação de 
diamante fantasia (fancy). Nesse caso as cores mais valorizadas no mercado são vermelho, azul, rosa, verde, violeta, púrpura e lilás. Segundo Fritsch (1998) a cor laranja é a mais rara e valorizada no mercado atual. A Fotografia 6.1 reproduzida de King et al. (1994) apresenta um conjunto magnífico de diamantes do tipo fantasia lapidados, ilustrando ao mesmo tempo os cortes mais importantes do mercado.

A ocorrência de diamantes fortemente coloridos (fantasia), constituiu durante muito tempo, meras curiosidades mineralógicas de interesse de museus e colecionadores. Contudo, essa situação sofreu uma mudança brusca a partir de outubro de 1987, quando uma gema vermelha de apenas $0,95 \mathrm{ct}$ foi leiloada em New York pela cifra de um milhão de dólares. A partir desta data, cresceu o interesse e a procura pelos diamantes fantasia, impulsionando não só o comércio como também os trabalhos de geologia e mineração em todo o mundo (Fritsch 1998). Diamantes fantasia são raros ou ausentes nas áreas estudadas neste trabalho. Contudo, tais diamantes são relativamente comuns na região de Coromandel, especialmente nos garimpos dos rios Santo Antônio, Santo Inácio e Douradinho (Svisero, informações pessoais).

A origem da cor do diamante está relacionada à impurezas químicas ( $p$. e. nitrogênio) e a defeitos cristalinos, também conhecidos sob a denominação de centros de cor, ou simplesmente centros (Clark et al. 1979). Muitos centros são o resultado da combinação de um defeito estrutural com algum tipo de impureza. Vários centros já foram caracterizados na estrutura do diamante; talvez o mais comum seja aquele representado pela ausência de um átomo de carbono na rede, denominado na literatura de centro GR (general radiation center). Diversos centros incorporam nitrogênio, a impureza mais comum no diamante. Neste caso, a cor associada é o amarelo que se manifesta desde tonalidades claras até tons fortes como o arnarelo canário. No primeiro caso, os tons leves de amarelo depreciam o diamante, mas no segundo caso, a cor intensa torna a pedra um diamante fantasia, de grande valor no mercado. Por outro lado, no caso da impureza ser o boro, forma-se outro tipo de centro responsável pela cor azul de certos diamantes. De um modo geral, a identificação dos centros de cor do diamante é um assunto complexo constituindo um tema tratado pela física do estado sólido (Fritsch 1998). Tendo em vista esse fato, e considerado que o estudo da cor teve apenas um objetivo classificatório, uma análise mais profunda dessas questões estão além dos objetivos desse trabalho. 


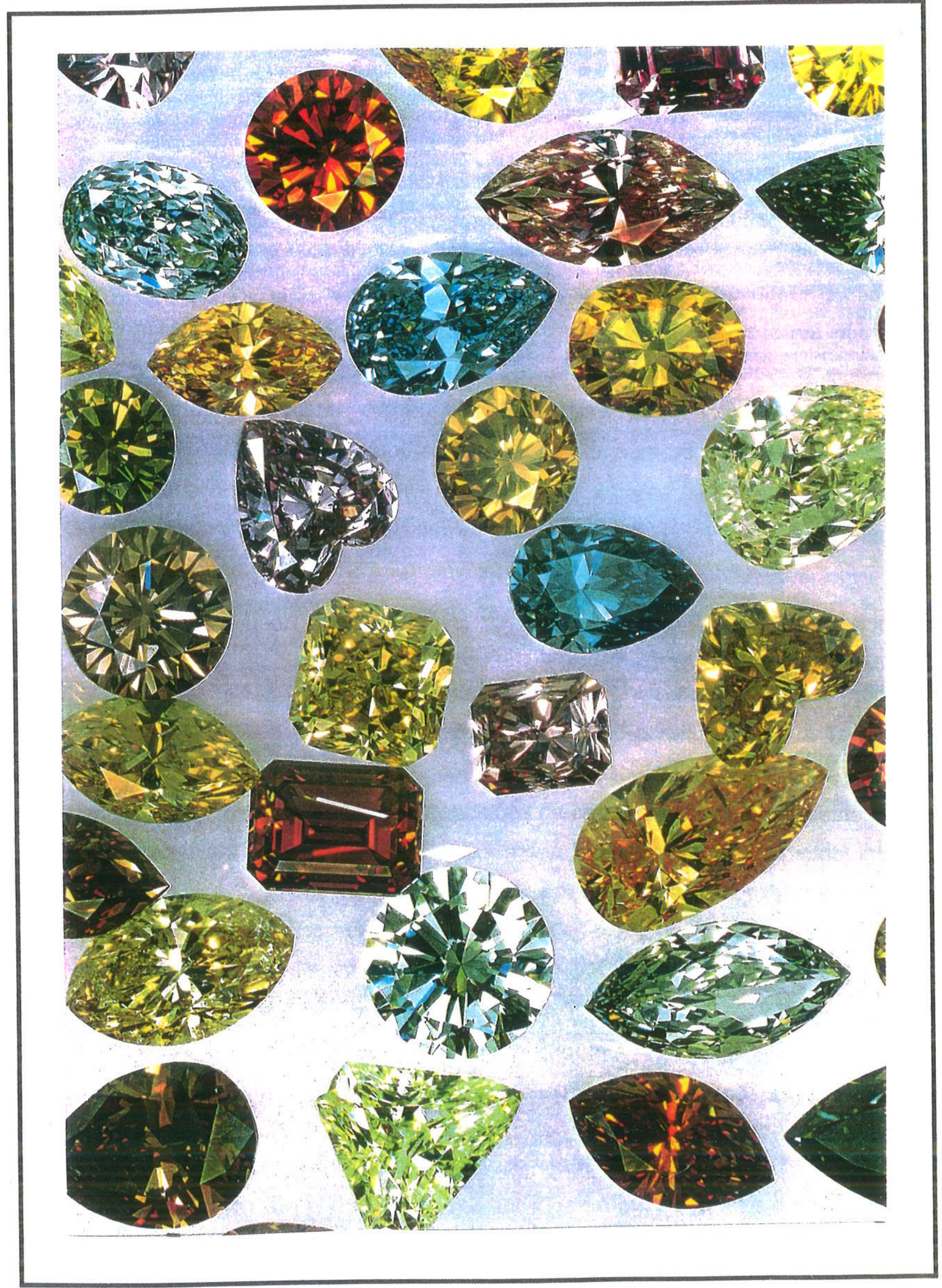

Fotografia 6.1 - Coleção de diamantes do tipo fantasia (fancy) lapidados segundo os talhes brilhante, navete, gota, esmeralda, oval, coração e quadrada. Reproduzida de King et al. (1994). 


\subsubsection{Dados desta dissertação}

No decorrer desse trabalho, a identificação individual da cor do diamante foi realizada por comparação visual e conjunta dos cristais em cada um dos lotes examinados. Em uma primeira fase do trabalho, foram criadas diversas categorias de cor com o objetivo de contemplar todas as variações de tonalidades possíveis observadas. Após os primeiros ensaios, verificou-se que esse procedimento criava um número muito grande de classes, e que as diferenças de tonalidade eram muito sutis entre si. Em muitos casos, verificou-se que havia dificuldade em escolher a categoria de um determinado cristal diante das diferenças pequenas entre as classes estabelecidas. Assim sendo, optou-se por reduzir o número de categorias de cor, procedimento adotado inclusive por diversos outros autores da literatura (Harris et al 1975, 1979; Otter et al. 1994; McCallum et al. 1979, 1994). Levando em conta que um dos objetivos desse trabalho era efetuar correlações com diamantes de outras áreas geográficas, adotou-se dentro do possivel as categorias de cor utilizadas anteriormente nos trabalhos de Svisero et al (1981), Chieregati (1989) e Chaves (1997).

Os resultados obtidos estão sintetizados nas Tabelas 6.1 e 6.2. as quais apresentam a distribuição da cor do diamante das regiões estudadas. Na Tabela 6.1. as categorias de cor estão mostradas apenas em função do número total de amostras examinadas, uma vez que não houve condições de caracterizar a granulometria dessas amostras, enquanto que na Tabela 6.2. as cores identificadas estão distribuidas em função dos intervalos granulométricos. Como se pode observar pelas referidas tabelas, a variedade incolor $(52,4 \%)$ predomina em todas as áreas estudadas, sendo seguida pelo castanho $(25,0 \%)$, cinza $(15,2 \%)$ e amarelo $(7,0 \%)$, e em proporções bem menores pelo preto $(0,2 \%)$, rosa $(0,1 \%)$, verde $(0,1 \%)$ e lilás $(0,1 \%)$. Os valores encontrados estão reunidos em um conjunto de diagramas de barras que constituem as Figuras 6.1, 6.2 e 6.3, onde estão bem visualizados as freqüências das cores observadas. 
Tabela 6.1 - Distribuição das cores observadas em diamantes provenientes das regiöes de Poxoréu (lote Px3) e Paranatinga (lote Pa1), Mato Grosso, nos quais predominam os cristais incolores seguidos dos castanhos e amarelos.

\begin{tabular}{|l|r|r|}
\hline Lote & \multicolumn{1}{|c|}{ Px(3) } & \multicolumn{1}{|c|}{ Pa(1) } \\
\hline Cor & \multicolumn{2}{|c|}{$\mathrm{n}^{\circ}$. cristais } \\
\hline Incolor & 350 & 624 \\
\hline Amarelo & 52 & 84 \\
\hline Castanho & 219 & 298 \\
\hline Cinza & 29 & 181 \\
\hline Verde & 1 & 1 \\
\hline Rosa & 0 & 1 \\
\hline Preto & 0 & 2 \\
\hline total & 651 & 1191 \\
\hline
\end{tabular}

$\mathrm{Na}$ descrição destes lotes, ficou bem evidenciado que entre os diamantes gemológicos predominaram os cristais incolores de hábitos bem definidos, variando entre octaédricos a rombododecaédricos. Por outro lado, nos lotes do tipo indústria, predominaram os cristais castanho e cinza com tonalidades variáveis, constituídos por formas cristalinas irregulares, geminados, agregados cristalinos, fragmentos de clivagem e variedades policristalinas (carbonado e ballas).

\subsubsection{Discussão}

De modo geral, os trabalhos desenvolvidos na literatura a respeito da cor macroscópica do diamante, não obstante a distância entre as áreas estudadas e a diferente natureza dos tipos de depósitos, são em linhas gerais concordantes. Como se pode observar pela Tabela 6.3 os diamantes incolores predominam em todos os depósitos listados na tabela, sejam eles kimberlíticos ou detríticos. Além disso, existe um padrão concordante na freqüencia das demais cores uma vez que, após os incolores, seguem-se os castanhos, amarelos e cinzas, sendo as demais cores de ocorrência casual.

Harris et al. (1975) observaram um padrão semelhante entre a cor do diamante 


\begin{tabular}{|c|c|c|c|c|c|c|c|c|c|c|c|c|c|c|c|c|c|c|c|c|c|c|c|c|c|c|c|}
\hline Lote & \multicolumn{3}{|c|}{$\mathrm{CG}(1)$} & \multicolumn{3}{|c|}{$\mathrm{CG}(2)$} & \multicolumn{5}{|c|}{$\mathrm{CG}(3)$} & \multicolumn{4}{|c|}{$P \times(1)$} & \multicolumn{5}{|c|}{$P \times(2)$} & \multicolumn{4}{|c|}{$\mathrm{Di}(1)$} & \multicolumn{3}{|c|}{$A P(1)$} \\
\hline $\begin{array}{c}\text { Crivo } \\
\mathrm{mm}\end{array}$ & 1 & A & $\mathrm{Ca}$ & 1 & $A$ & $\mathrm{Ca}$ & 1 & A & $\mathrm{Ca}$ & V & $R$ & 1 & A & $\mathrm{Ca}$ & $\mathrm{Cl}$ & 1 & A & $\mathrm{Ca}$ & $\mathrm{Ci}$ & $R$ & 1 & A & $\mathrm{Ca}$ & $\mathrm{Ci}$ & 1 & A. & $\mathrm{Ca}$ \\
\hline$<$ & 0 & 0 & 0 & 0 & 0 & 0 & 0 & 0) & 0 & 이 & 0 & 4 & 0 & 0 & 0 & 60 & 0 & 38 & 이 & 0 & 31 & 0 & 4 & 0 & 0 & 이 & 0 \\
\hline 1,7 & 2 & 1 & 1 & 3 & 0 & 11 & 0 & 0 & 0 & 2 & 0 & 12 & 6 & 1 & 0 & 20 & 13 & 9 & 0 & 0 & 32 & 0 & 7 & 1 & 7 & 0 & 1 \\
\hline 1,9 & 7 & 4 & 0 & 4 & 0 & 1 & 4 & 0 & 3 & 0 & 0 & 22 & 3 & 5 & 0 & 35 & 0 & 8 & 0 & 0 & 27 & 0 & 7 & 1 & 8 & 0 & 1 \\
\hline 2,2 & 6 & 3 & 3 & 8 & 0 & 01 & 5 & 2 & 2 & 0 & 11 & 55 & 10 & 13 & 0 & 41 & 15 & 21 & 0 & 0 & 54 & 0 & 13 & 0 & 10 & 0 & 6 \\
\hline 2,5 & 7 & 0 & 2 & 2 & 0 & 2 & 10 & 6 & 0 & 0 & 0 & 36 & 7 & 9 & 0 & 32 & 0 & 11 & 0 & 0 & 22 & 1 & 6 & 0 & 13 & 0 & 1 \\
\hline 2,7 & 8 & 3 & 2 & 2 & 0 & 0 & 4 & 4 & 3 & 0 & 0 & 13 & 2 & 3 & 이 & 4 & 4 & 7 & 1 & 0 & 7 & 1 & 0 & 0 & 17 & 5 & 0 \\
\hline 3 & 11 & 2 & 2 & 3 & 3 & 0 & 2 & 0 & 2 & 1 & 0 & 26 & 6 & 4 & 0 & 43 & 7 & 8 & 0 & 2 & 23 & 0 & 3 & 2 & 9 & 5 & 0 \\
\hline 3,3 & 1 & 0 & 2 & 1 & 0 & 1 & 6 & 8 & 1 & 2 & 0 & 15 & 0 & 3 & 0 & 12 & 5 & 4 & 0 & 0 & 7 & 1 & 1 & 0 & 6 & 1 & 0 \\
\hline 3,6 & 3 & 0 & 2 & 1 & 이 & 0 & 2 & 5 & 0 & 0 & 0 & 20 & 1 & 7 & 1 & 15 & 2 & 5 & 0 & 0 & 6 & 0 & 3 & 1 & 9 & 4 & 0 \\
\hline 3,9 & 5 & 0 & 0 & 0 & 0 & 0 & 3 & 5 & 3 & 2 & 0 & 6 & 2 & 0 & 0 & 4 & 5 & 3 & 0 & 0 & 2 & 0 & 0 & 0 & 3 & 0 & 0 \\
\hline 4,1 & 5 & 0 & 0 & 0 & 1 & 0 & 3 & 1 & 2 & 0 & 0 & 8 & of & 1 & 0 & 6 & 1 & 4 & 0 & 0 & 1 & 0 & 1 & 0 & 0 & 0 & 0 \\
\hline 4,3 & 7 & 1 & 0 & 0 & 0 & 0 & 0 & 1 & 1 & 0 & 0 & 6 & 2 & 4 & 0 & 8 & 0 & 0 & o & 0 & 1 & 1 & 0 & 0 & 3 & 1 & 0 \\
\hline$>$ & 0 & 0 & 0 & 3 & 0 & 0 & 8 & 0) & 2 & 4 & 0 & 20 & 2 & 1 & 0 & 19 & 4 & 0 & 3 & 0 & 1 & 0 & 0 & 0 & 5 & 0 & 0 \\
\hline total & 62 & 14 & 14 & 27 & 4 & 5 & 47 & 32 & 19 & 8 & 1 & 243 & 41 & 511 & 1 & 299 & 56 & 118 & 4 & 2 & 214 & 4 & 45 & 5 & 90 & 16 & 9 \\
\hline
\end{tabular}

\begin{tabular}{|c|c|c|c|c|c|c|c|c|c|c|c|c|c|c|c|c|c|}
\hline \begin{tabular}{|l|} 
Lote \\
\end{tabular} & \multicolumn{5}{|c|}{$\mathrm{AP}(2)$} & \multicolumn{5}{|c|}{$\mathrm{AP}(3)$} & \multicolumn{7}{|c|}{$\mathrm{AP}(4)$} \\
\hline $\begin{array}{c}\text { Crivo } \\
\mathrm{mm}\end{array}$ & 1 & A & & & & & A & $\mathrm{Ca}$ & & V & 1 & A & $\mathrm{Ca}$ & $\mathrm{Cl}$ & $V$ & $R$ & $L$ \\
\hline$<$ & 74 & 3 & $\frac{\mathrm{Ca}}{12}$ & $\frac{\mathrm{Cl}}{\mathrm{O}}$ & $\frac{v}{0}$ & $\frac{1}{4}$ & 0 & 3 & 0 & 0 & 11 & 7 & 0 & 0 & 0 & 0 & 0 \\
\hline 1,7 & 36 & 0 & 13 & 0 & 0 & 8 & 0 & 0 & 0 & 0 & 28 & 0 & 7 & 0 & 0 & 1 & 0 \\
\hline 1,9 & 36 & 0 & 11 & 0 & 1 & 4 & 0 & 0 & 0 & 0 & 12 & 24 & 2 & 0 & 1 & 0 & 0 \\
\hline 2,2 & 33 & 0 & 8 & 0 & 0 & 7 & 8 & 2 & 0 & 0 & 43 & 26 & 8 & 0 & 0 & 0 & 0 \\
\hline 2,5 & 25 & 4 & 2 & 0 & 0 & 1 & 4 & 0 & 3 & 0 & 46 & 8 & 15 & 0 & 0 & 0 & $u$ \\
\hline 2,7 & 18 & 0 & 1 & 1 & 0 & 3 & 0 & 0 & 0 & 0 & 8 & 5 & 2 & 0 & 0 & 0 & 1 \\
\hline 3 & 39 & 이 & 6 & 0 & 0 & 2 & 0 & 2 & 0 & 1 & 49 & 11 & 10 & 0 & 0 & 0 & 0 \\
\hline 3,3 & 14 & 2 & 2 & 0 & 0 & 0 & 0 & 0 & 0 & 0 & 19 & 9 & 1 & 4 & 1 & 0 & 0 \\
\hline 3,6 & 18 & 2 & 0 & 0 & 0 & 1 & 0 & 0 & 0 & 0 & 31 & 3 & 10 & 0 & 0 & 0 & 0 \\
\hline 3,9 & 9 & 2 & 0 & 0 & 0 & 1 & 0 & 0 & 0 & 0 & 11 & 3 & 0 & 0 & 1 & 0 & 0 \\
\hline 4,1 & 4 & 1 & 0 & 1 & 0 & 0 & 0 & 0 & 0 & 0 & 19 & 2 & 3 & 0 & 0 & 0 & 0 \\
\hline 4,3 & 0 & 0 & 0 & 0 & 0 & 0 & 0 & 0 & 0 & 0 & 7 & 3 & 0 & 0 & 0 & 0 & 0 \\
\hline$>$ & 10 & 0 & 0 & 0 & 0 & 3 & 0 & 0 & 0 & 0 & 22 & 4 & 1 & 1 & 0 & 0 & 0 \\
\hline total & 316 & 14 & 55 & 2 & 1 & 34 & 12 & 7 & 3 & 1 & 306 & 105 & 59 & 5 & 3 & 1 & 1 \\
\hline
\end{tabular}

Tabela 6.2 - Distribuição da cor em diamantes das regiōes de Chapada dos Guimarães (lotes CG1, CG2 e CG3), Poxoréu (lotes Px1 e Px2), Diamantino (lote Di1) e Alto Paraguai (lote AP1, AP2 e AP3). Legenda: i -incolor A amarelo, $\mathrm{Ca}$ - castanho, $\mathrm{Ci}$ - cinza, $\mathrm{V}$-verde, $\mathrm{R}$ -rosa, L- lilás. 


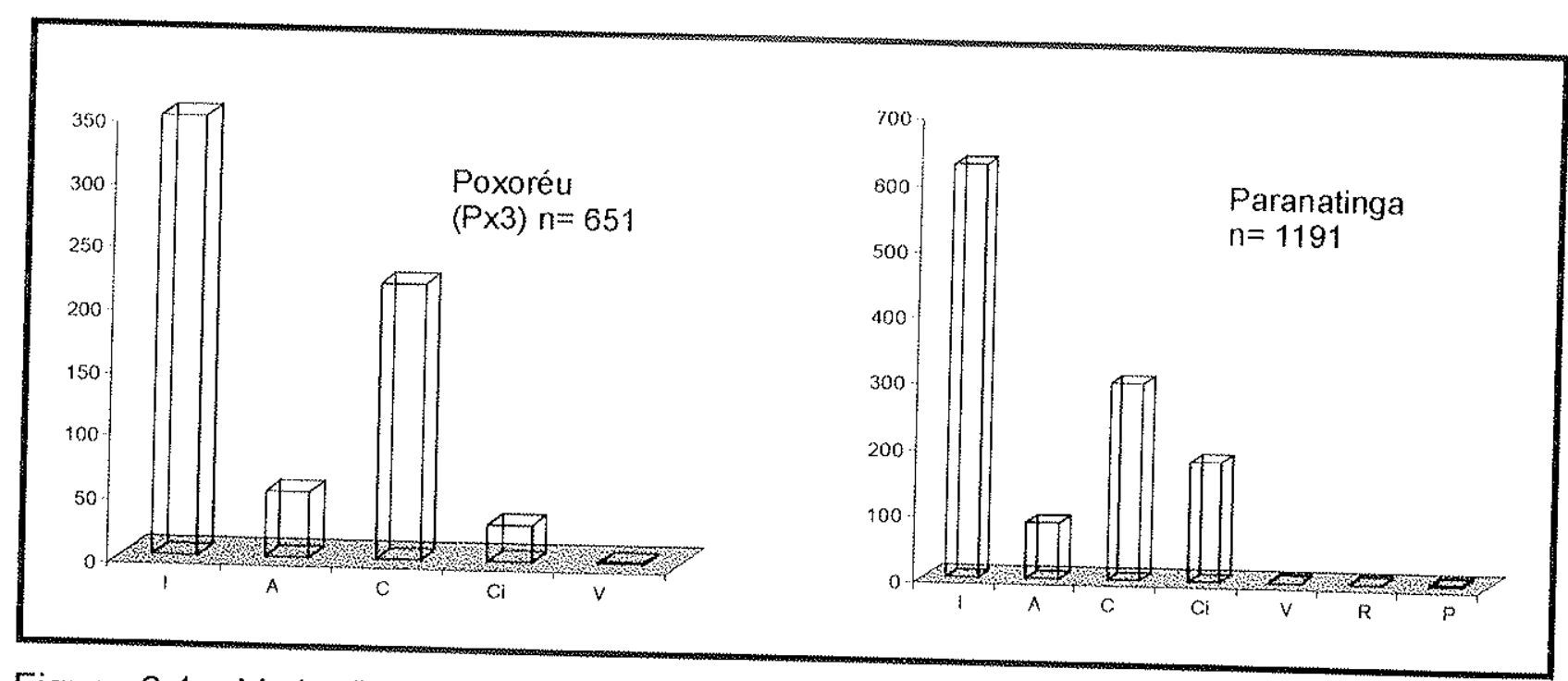

Figura 6.1 - Variação da cor em função do número total de diamantes das regiões de Poxoréu e Paranatinga. Legenda: I - incolor, C - castanho, A - amarelo, Ci - cinza, V-verde, $\mathrm{R}$ - rosa e $\mathrm{P}$ - preto; $\mathrm{n}=$ número de cristais.

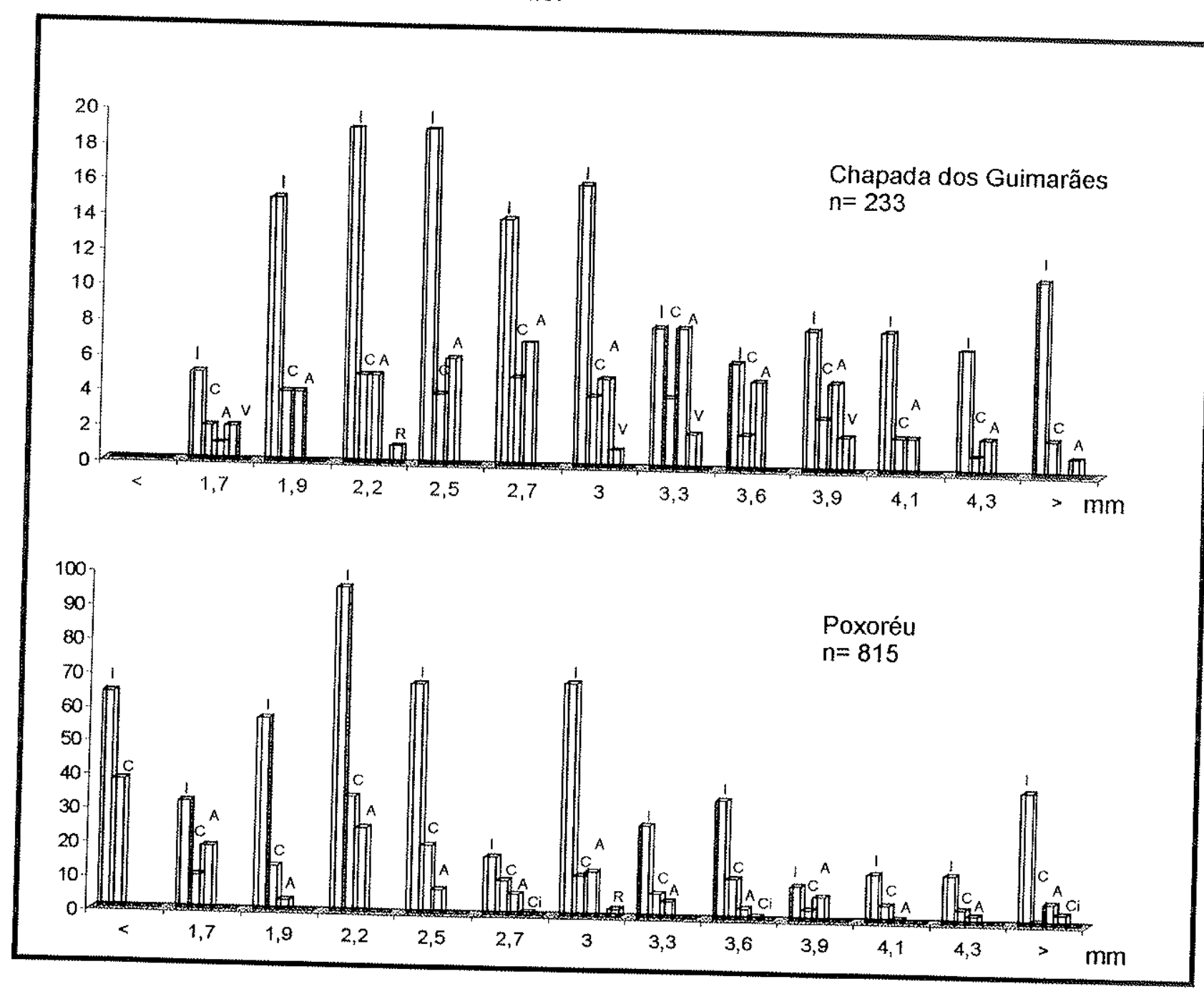

Figura 6.2 - Freqüência da cor versus a granulometria de diamantes das regiões de Chapada dos Guimarães e Poxoréu (lotes Px1 e Px2), Mato Grosso. Legenda: I - incolor, $\mathrm{C}$ - castanho, A-amarelo, $\mathrm{Ci}$ - cinza, $\mathrm{V}$-verde, $\mathrm{R}$ - rosa; $\mathrm{n}=$ número de cristais. 

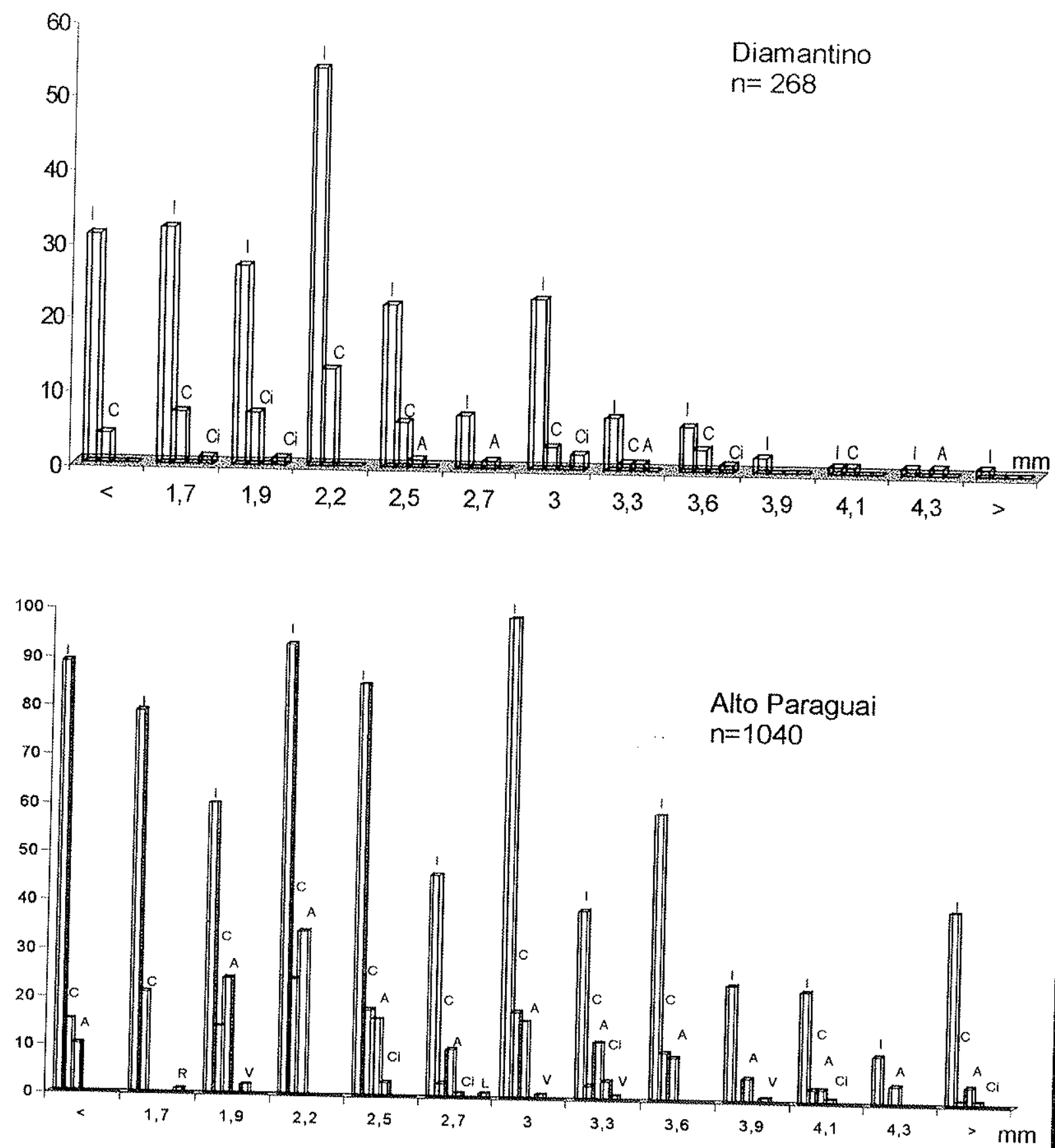

Figura 6.3 - Freqüência da cor em função da granulometria $(\mathrm{mm})$ de diamantes de Diamantino e Alto Paraguai, Mato Grosso. Legenda: I-incolor, A - amarelo, C - castanho,
$\mathrm{Ci}$ - cinza, V-verde, R - rosa e L - lilás. 
dos Kimberlitos Premier, Finsch e Koffyfontein, e do depósito aluvionar de Dreyers Pan, África do Sul. No caso das minas Premier e Finsch, os referidos autores notaram um aumento da cor amarela e uma diminuição da cor castanha, acompanhando o aumento do tamanho do diamante. Quanto à freqüência das cores em cada mina, Harris et al. (1975) destacaram: a) alta porcentagem de pedras incolores e quase ausência de diamante verde em Koffyfontein; b) uma porcentagem maior de diamantes verdes em Dryers Pan do que na mina Finsch; c) a ocorrência de diamantes azuis, cerca de 0,5\%, na mina Premier. Em trabalho posterior, Harris et al. (1979) incluiu os Kimberlitos Zwartruggens, Letseng-le-terai e Ebenhaezer e Kimberley, destacando a presença de diamantes de cor laranja em Zwartruggens, e a variação da cor com a profundidade nas minas Finsch e Koffyfontein. Continuando esses estudos, Harris et al. (1984) observaram uma alta proporção de diamantes de cor castanha (brown) exibindo deformação plástica. Analogamente, Robinson (1989) relacionou também a alteração da cor primária para a cor castanha à deformação plástica do diamante, a qual poderia estar associada à pressão resultante do emplacement do kimberlito.

Trabalhos semelhantes foram desenvolvidos nos kimberlitos localizados na fronteira entre os estados de Colorado e Wyoming (State Line District). Conforme está mostrado na Tabela 6.3, Otter et al. (1994) destacaram que ao contrário de outros locais, a cor castanha predomina nas intrusões Sloan 1 e 2 (60 a 70\%), seguida da cor cinza $(\cong 25 \%$ ) e incolor (<10\%). Estes dados contrastam com os de McCallum et al. (1979), segundo os quais predominam as cores é incolor $(54 \%)$, castanho $(11 \%) \mathrm{e}$ cinza $(6 \%)$. A diferença entre os dados desses autores pode ser devida ao número de exemplares constituintes dos lotes estudados, uma vez que McCallum et al (1979) baseou-se em 78 cristais e Otter et al. (1994) em 1816 exemplares. McCallum et al. (1994) observou anda que a cor cinza é ocasionada pela presença de pequenas e abundantes inclusões de sulfetos, grafita e hematita disseminadas no interior dos cristais.

Com relação aos diamantes detríticos das áreas brasileiras, observa-se uma semelhança nos padrões de freqüência das cores, embora haja diferenças nas porcentagens reportadas (Tabela 6.3). Considerando os cristais incolores, por exemplo, observa-se uma variação que vai desde $48 \%$ na região de Alto Araguaia, Mato Grosso (Svisero 1971) até 97\% na região da Serra do Espinhaço em Minas Gerais (Chaves 1997). Assim sendo as variações observadas no decorrer dessa dissertação (58 a $80 \%$ ), enquadram-se no referido intervalo, assemelhando-se às dos garimpos da região 

Tabela 6.3 - Comparação da cor de diamantes detríticos e kimberlíticos de diferentes localidades geográficas. Destaca-se o predomínio dos tipos incolor, seguidos dos castanho,
amarelo e cinza, sendo as demais cores menos freqüentes.

\begin{tabular}{|c|c|c|c|c|c|c|c|c|c|c|c|c|}
\hline Autores & & ocalidade & Incolor & Castanho & Amarelo & Cinza & Verde & Rosa & Lilás & Preto & Outros & fonte \\
\hline \multirow{5}{*}{$\begin{array}{l}\text { Esta dissertação: } \\
\text { Região central de } \\
\text { Mato Grosso } \\
n=4198\end{array}$} & \multicolumn{2}{|c|}{ Chapada dos Guimarães } & 58 & 16,3 & 21,45 & - & 3,43 & 0,42 & - & - & - & \\
\hline & \multicolumn{2}{|c|}{ Poxoréu } & 60,84 & 26,46 & 10,16 & 2,31 & 0,06 & 0,13 & - & - & - & \\
\hline & \multicolumn{2}{|c|}{ Paranatinga } & 52,39 & 25,02 & 7,05 & 15,19 & 0,08 & 0,08 & - & 0,16 & - & \\
\hline & \multicolumn{2}{|c|}{ Diamantino } & 79,85 & 16,79 & 1,49 & 1,86 & - & - & - & $-\quad$ & - & \\
\hline & \multicolumn{2}{|c|}{ Alto Paraguai } & 71,73 & 12,5 & 14,13 & 0,96 & 0,48 & 0,09 & 0,09 & - & $\sim$ & \\
\hline \multirow{3}{*}{$\begin{array}{c}\text { Chaves (1997) } \\
\text { Região da Serra do } \\
\text { Espinhaço, MG } \\
n=3027\end{array}$} & \multicolumn{2}{|l|}{ Datas } & 96,98 & 1,34 & 1,67 & - & - & - & - & - & - & \\
\hline & \multicolumn{2}{|c|}{ Rio Jequitinhonha } & 96,97 & 0,80 & 1,75 & 0,16 & - & - & - & - & 0,32 & \\
\hline & \multicolumn{2}{|c|}{ Grã̃o Mogol } & 95,18 & 1,56 & 1,8 & 0,78 & - & - & - & 0,26 & 0,52 & $\begin{array}{l}\text { Diamantes } \\
\text { detriticos }\end{array}$ \\
\hline \multirow{3}{*}{$\begin{array}{c}\text { Chieregati (1989) } \\
\text { Região do Tibagi, PR } \\
n=2377\end{array}$} & \multicolumn{2}{|c|}{ Itararé-Jaguariaiva } & 58,4 & 26,2 & 12,1 & - & - & - & - & - & 3,4 & \\
\hline & \multicolumn{2}{|c|}{ Telêmaco- Borba- Tibagi } & 52,2 & 43,7 & 2,7 & - & 1,3 & - & - & - & - & \\
\hline & \multicolumn{2}{|c|}{ Atomon, Telêmaco Borba } & 57,94 & 30,10 & 7,6 & - & 4,36 & - & - & - & - & \\
\hline $\begin{array}{l}\text { Svisero \& Haralyi (1985) } \\
n=5317\end{array}$ & \multicolumn{2}{|c|}{ Mina de Romaria, $\mathrm{MG}$} & 76,0 & - & 3,38 & 19,65 & - & - & - & - & 0,92 & \\
\hline Svisero $(1971) n=500$ & \multicolumn{2}{|c|}{ Alto Araguaia, MT } & 48 & 22 & 17 & 6 & 6 & - & - & - & 1 & \\
\hline Yurk (1966) & \multicolumn{2}{|c|}{ Ucrânia } & $60-80$ & - & $2-12$ & + & $2-8$ & - & - & - & $7-13$ & \\
\hline \multirow{8}{*}{$\begin{array}{c}\text { McCallum et al. }(1994) \\
\text { Colorado-Wyoming } \\
n=3917\end{array}$} & \multicolumn{2}{|l|}{ Sloan 1} & 77 & 63 & - & - & - & - & - & - & $=$ & \\
\hline & \multicolumn{2}{|c|}{ Sloan 2} & 4 & 70 & - & - & - & - & - & - & - & \\
\hline & \multicolumn{2}{|c|}{ Chicken Park } & 76 & 8 & - & - & - & - & - & - & - & \\
\hline & \multicolumn{2}{|c|}{ George Creek 1} & 81 & 4 & - & - & - & - & - & - & - & \\
\hline & \multicolumn{2}{|c|}{ George Creek 2} & 42 & 48 & - & - & - & - & - & - & - & \\
\hline & \multicolumn{2}{|c|}{ Aultman } & 69 & 28 & - & - & - & $=$ & - & - & - & \\
\hline & \multicolumn{2}{|c|}{ Maxwell } & 36 & 56 & - & - & - & - & - & - & - & Diamantes \\
\hline & \multicolumn{2}{|c|}{ Schaffer } & 43 & 30 & - & - & - & - & - & - & - & kimberlíticos \\
\hline \multirow{2}{*}{$\begin{array}{l}\text { Otter et al. (1994) } \\
\text { Colorado-Wyoming } \\
n=1816\end{array}$} & \multicolumn{2}{|l|}{ Sloan 1} & 6,3 & 62,4 & 0,4 & 27,5 & 1,1 & 0,4 & - & - & 1,8 & \\
\hline & \multicolumn{2}{|l|}{ Sloan 2} & 3,7 & 70,3 & - & 24,7 & 0,4 & 0,2 & - & - & 0,6 & \\
\hline $\begin{array}{c}\text { McCallum et al. (1979) } \\
\text { Colorado-Wyoming } \\
\mathrm{n}=78\end{array}$ & Sloan 1 & & 54 & 11 & 5 & 6 & - & - & - & 2 & - & \\
\hline Whitelock (1973) & & cristais & 68 & 17 & 10 & - & - & - & - & - & 5 & \\
\hline $\begin{array}{c}\text { Lesotho } \\
n=5000\end{array}$ & Quarry & irregulares & 50 & 21 & 6 & - & - & - & - & - & 23 & \\
\hline
\end{tabular}


do Tibagi, com $58 \%$ (Chieregati 1989). De modo geral esse parâmetro físico concordou com as tendências observadas em outras áreas geográficas, não tendo havido nenhum fato discrepante que merecesse registro especial. Os resultados obtidos serão discutidos na classificação gemológica do diamante a ser efetuada no capítulo subseqüente.

\subsection{Fluorescência}

Luminescência é a emissão de luz visível por materiais submetidos a algum tipo de radiação excitante, entre as quais a mais utilizada é a ultravioleta (UV). Como regra geral, sabe-se que um terço dos diamantes naturais são luminescentes. O fenômeno luminescente é denominado fluorescência quando a emissão de luz cessa com a interrupção da luz excitante, e fosforescência no caso da emissão de luz prosseguir mesmo após a fonte incidente ser removida. Em outras palavras, a fluorescência pode ser interpretada como o inverso da absorção. Nos exames rotineiros utilizou-se uma lâmpada que emite radiação UV em dois comprimentos de onda distintos; UV de comprimento de onda curto $\operatorname{com} \lambda=253,7 \mathrm{n}$ e UV de comprimento de onda longo $\lambda$ $=366 \mathrm{n}$.

Durante a absorção, os elétrons absorvem energia saltando para niveis mais energizados, e durante a fluorescência, retornam aos níveis menos energéticos emitindo energia na forma de luz visível. Nesse processo, parte da energia absorvida perde-se na forma de calor (Nassau 1983). Quando um diamante absorve radiação UV, ele pode emitir luz fluorescente na faixa visivel indicando perda pequena de energia. Por outro lado, se a pedra é excitada por luz visível, ela pode absorver níveis de energia mais altos do azul e do violeta, emitindo luz fluorescente verde de menor energia. Esse é o caso dos diamantes do tipo Chartreuse, denominados também transmissores verdes (Fritsch 1998).

No diamante, o fenômeno luminescente é provocado por centros ópticos de vários tipos cujos elétrons emitem uma radiação característica denominada cor de luminescência, ao serem excitados por uma fonte externa. Se a luz incidente for luz visível, radiação ultravioleta ou raios $X$, o fenômeno denomina-se fotoluminescência; por outro lado, se a luminescência for provocada pela incidência de elétrons, o fenômeno neste caso recebe o nome de catodoluminescência (Wilks \& Wilks 1994). 
Essa última propriedade, embora incluida na Tabela 2.1 entre as propriedades físicas do diamante, não será tratada no decorrer dessa dissertação, uma vez que o propósito do presente trabalho é enfatizar as propriedades utilizadas nas classificações gemológicas do diamante.

Durante muito tempo predominou no mercado a idéia de que a fluorescência causava um efeito negativo no diamante. Moses et al. (1997) realizaram um experimento para investigar a veracidade ou não desse fato. Nesse sentido, utilizaram quatro diamantes lapidados no talhe brilhante, de cores variando entre o incolor e o amarelo claro, os quais foram examinados sob radiação ultravioleta, tanto por gemólogos especializados, como por potenciais compradores de gemas. Ambos os grupos examinaram os referidos diamantes em situações variadas, e ao final do experimento, concluiu-se que o efeito de fluorescência não afetava a transparência e nem a cor do diamante no mercado. Foi observado também uma pequena influência da fluorescência nas categorias inferiores de cor, especificamente nos tipos I e $\mathrm{K}$ da escala de cor do Gemological Institute of America (GIA). Outros pormenores pertinentes à classificação da cor serão discutidos no capítulo subseqüente.

\subsubsection{Dados desta dissertação}

Esta propriedade foi estudada empregando-se uma lâmpada ultravioleta modelo 910 E-9 m, com comprimento de onda de 366 nanômetro, na qual foi observada a cor emitida por cada um dos cristais após a exposição de alguns minutos às referidas radiações. Por motivos de ordem técnica, só foi possível registrar a fluorescência de alguns lotes de diamante das regiões de Chapada dos Guimarães (126 amostras), Diamantino (268 amostras) e Alto Paraguai (445 amostras), nos quais foram observadas as seguintes porcentagens de fluorescência: $17,46 \%, 9,7 \%$ e 1,01\%, respectivamente (Tabela 6.4). Observou-se em todas as regiões amostradas o domínio absoluto da cor de fluorescência azul, seguindo-se por ordem de freqüência as cores rosa, amarela, cinza e, em menor do proporção a cor verde. Além disso, a proporção de indivíduos fluorescentes variou entre as áreas amostradas. 
Tabela 6.4 - Cor de fluorescência registrada durante o exame de lotes de diamantes das regiões de Chapada dos Guimarães, Diamantino e Alto Paraguai, Mato Grosso.

\begin{tabular}{|l|r|r|r|r|r|r|}
\hline Cor $\downarrow$ lote $\rightarrow$ & $\begin{array}{c}\text { CG (1) } \\
n=90\end{array}$ & $\begin{array}{c}\text { CG (2) } \\
n=36\end{array}$ & $\begin{array}{c}\text { Di (1) } \\
n=268\end{array}$ & $\begin{array}{c}\text { AP (2) } \\
n=388\end{array}$ & $\begin{array}{c}\text { AP (3) } \\
n=57\end{array}$ & Total \\
\hline Azul & 5 & 6 & 21 & 32 & 9 & 73 \\
\hline Amarelo & 5 & 0 & 1 & 1 & 0 & 7 \\
\hline Cinza & 1 & 0 & 0 & 1 & 0 & 2 \\
\hline Rosa & 5 & 0 & 1 & 2 & 0 & 8 \\
\hline Verde & 0 & 0 & 2 & 0 & 0 & 2 \\
\hline Total & 16 & 6 & 26 & 36 & 9 & 28,17 \\
\hline $\begin{array}{l}\text { área em cada } \\
\text { na número de cristais de cada lote }\end{array}$ \\
n
\end{tabular}

\subsection{Inclusões}

Em gemologia, o termo inclusão tem uma conotação ampla e abrange todo tipo de defeito cristalino observado no interior do diamante, incluindo-se fases minerais de composição, forma e cor diversas, clivagens e fraturas internas, zoneamentos, fraturas de tensão, linhas e planos de geminação e de crescimento, e figuras de aspectos variados resultantes da concentração de cristais submicroscópicos de uma certa fase mineral, ou ainda defeitos que se adensam em determinados setores do cristal assumindo aspectos variados (nuvens, pena, entre outros). De um modo geral, as inclusões apresentam cores variáveis e dimensões entre 1 a $0,01 \mathrm{~mm}(\cong 100 \mu \mathrm{m})$; entretanto, algumas mais desenvolvidas podem alcançar vários milímetros, especialmente as manchas negras (Pagel-Theisen 1986, Gubelin \& Koivula (1992). A presença de inclusões nos diamantes naturais constitui um aspecto relativamente comum, sendo um elemento útil para a identificação, bem como para a distinção entre diamante natural e seus diversos substitutos sintéticos existentes no comércio tais como moissanita, zircônia cúbica $\left(\mathrm{ZrO}_{2}\right)$, YAG $\left[\mathrm{Y}_{3} \mathrm{Al}_{2}\left(\mathrm{AlO}_{4}\right]\right.$, GGG [Gd $\mathrm{Ga}_{2}(\mathrm{GaO} 4$, fabulita $\left(\mathrm{CaTiO}_{3}\right)$, entre outros Nassau et al. (1997). 


\subsubsection{Inclusões minerais}

Do ponto de vista mineralógico e geológico, o estudo das inclusões minerais do diamante constitui uma importante linha de pesquisa na atualidade, e dela participam além de mineralogistas, petrólogos, geoquímicos e geofísicos de vários países do mundo. O objetivo inicial desses estudos era compreender os processos genéticos do diamante, porém, a evolução desses trabalhos tornou o estudo das inclusões uma importante linha de pesquisa voltada para o conhecimento da composição do manto. Meyer \& Tsai (1976), Harris \& Gurney (1979) e Meyer (1987) produziram excelentes artigos de revisão contendo o histórico e todos os principais aspectos da evolução dos estudos mineralógicos e geoquímicos realizados a partir dos anos sessenta. Essa data é tomada como referencial uma vez que foi somente a partir do uso da microssonda eletrônica que o conhecimento das inclusões do diamante adquiriu um padrão quantificado. Conforme mostrado por Meyer \& Tsai (1976), a major parte dos estudos anteriores eram realizados por observações macroscópicas e microscópicas (Eppler 1961) as quais não tinham poder de resolução para identificar inequivocamete as fases inclusas, resultando daí uma variedade enorme de fases minerais conflitantes com as condições de formação do diamante. Mesmo a difração de raios $X$ usada nos anos cinqüenta e sessenta, sobretudo por autores russos, só identificava a fase mineral deixando pendente a composição (Svisero 1984).

Conforme sintetizado por Meyer (1987), as principais fases minerais inclusas no diamante constituem duas suítes distintas denominadas peridotítica (ultramáfica) e eclogítica (máfica). Olivina, enstatita, diopsídio, cromiopiropo, magnésiocromita e ilmenita magnesiana são os principais constituintes do grupo peridotítico, enquanto que onfacita, piropo-almandina, ferrocromita, rutilo, coríndon, coesita e ilmenita entre outros, constituem as principais fases do grupo eclogítico. Todas essas fases minerais possuem características semelhantes às dos correspondentes minerais constituintes de xenólitos peridotíticos e eclogíticos do manto, encontrados em kimberlitos de diversas localidades (Nixon 1987). Entre outras informações fornecidas pelas inclusões do diamante merecem destaque os dados de termometria e barometria que extrapolados para o diamante revelaram as condições de pressão e temperatura de formação desse mineral, caracterizadas por temperaturas entre 900 a $1400^{\circ} \mathrm{C}$ e pressões entre 40 a 70 Kbars (Meyer 1987). Outro grande trunfo obtido pelos pesquisadores foi a datação das 
inclusões, obtendo-se idades discrepantes entre o diamante (3,5 Ga) e o kimberlito (90 $\mathrm{Ma}$ ), tornando claro desta forma que esse mineral é apenas um xenocristal na referida rocha (Richardson et al. 1984).

Nessa seqüência de descobertas fornecidas pelo estudo das inclusões, Wilding et al. (1991) reportou pela primeira vez a presença de inclusões com características químicas indicativas de profundidades correspondentes à zona de transição entre o manto superior e o manto inferior, ou seja profundidades entre 410 a $660 \mathrm{~km}$. A medida que esses trabalhos prosseguem, novos dados estão aparecendo na literatura internacional informando sobre novas inclusões cujas características apontam para condições de equilíbrio correspondentes a profundidades situadas abaixo da zona de transição, ou seja, no manto inferior (Haggerty 1995; Joswig et al. 1999).

\subsubsection{Defeitos estruturais}

Além das fases minerais mencionadas, conhecidas também pela denominação de bolhas entre os diamantários, as inclusões abrangem também diversos tipos de defeitos cristalinos entre os quais merecem destaque as clivagens e fraturas internas, bem como a existência de manchas escuras de formas e tamanhos variados, descritas entre os gemólogos pelos termos carvão e jaça.

O termo carvão é qualquer mancha escura que tanto pode ser produzida por um defeito estrutural da pedra (clivagem interna), quanto pela presença de um corpo estranho (mineral de cor escura aprisionado pelo diamante). Os carvões resultantes de clivagens internas constituem regiões planas e escuras enegrecidas principalmente nas partes centrais, pois resultam de descontinuidades estruturais bem determinadas. Como a clivagem do diamante é octaédrica, os carvões produzidos por defeitos mecânicos possuem orientações octaédricas. É freqüente duas ou mais superfícies enegrecidas se interceptarem dentro do cristal originando estruturas de aspectos curiosos descritas pelos gemólogos por denominações variadas (Pagel-Theisen 1986). Conforme discutido por Svisero (1971) a cor escura é produzida pela reflexão total da luz incidente que, ao passar do diamante (índice de refração=2,42) para a região de defeito onde reina vácuo (índice de refração $=1,0$ ), sofre reflexão total originando as manchas escuras, cujas formas dependem da extensão da clivagem.

A jaça também é produzida por clivagens interna da pedra, sendo isentas de cor 
escura. Na realidade, observações cuidadosas revelaram que existe uma gradação completa de cor entre os carvões escuros e as jaças claras. Por outro lado, é preciso levar em conta que algumas manchas escuras correspondem a minerais de cor preta tais como ilmenita, grafita e sulfetos. Segundo Harris (1968), os sulfetos são extremamente comuns ocorrendo sob a forma de películas finas orientadas ao longo de planos octaédricos. Os carvões relacionados à fases minerais possuem dimensões menores do que aqueles relacionados a defeitos cristalinos constituindo portanto um elemento de distinção visual entre estes dois tipos de carvões. Além disso os carvões relacionados a inclusões minerais possuem formas geométricas bem definidas, ao contrário das clivagens internas que são irregulares e descontínuas. O número, a posição, a forma e a intensidade desses defeitos exercem um papel importante na classificação gemológica do diamante, influindo na distinção entre os tipos gema/indústria, grau de aproveitamento da pedra, escolha do tipo de lapidação,e no grau de pureza da pedra (Svisero 1984, Pagel-Theisen 1986; GIA 1991).

\subsubsection{Dados desta dissertação}

Nesta dissertação, as inclusões foram estudadas apenas por métodos ópticos, já que os objetivos estão voltados para a classificação do diamante, na qual as inclusões constituem um item importante. Como será visto no capítulo subseqüente, as inclusões influem na caracterização do item pureza (clarity), que é um dos 4cs utilizados na avaliação de diamantes bruto e gemológico.

As observações realizadas com o auxílio de lupa de aumento 10x, permitiram distinguir diversos tipos de inclusões entre os diamantes de Chapada dos Guimarães, Poxoréu, Diamantino e Alto Paraguai. Os resultados obtidos estão reunidos na Tabela 6.5 , onde as inclusões estão separadas em função da cor e do intervalo granulométrico dos diamantes examinados. Excetuando-se um dos lotes de Chapada dos Guimarães onde só foram observadas inclusões incolores, nos demais lotes predominaram as inclusões pretas (carvões) seguidas das incolores (jaças).

As Fotomicrografias 6.1. ilustram alguns diamantes contendo inclusões minerais, as quais exibem orientação cristalográfica evidente, idiomorfismo acentuado, hábitos variados incluindo principalmente o tipo prismático e o globular. Na composição da montagem, as fotomicrografias do lado esquerdo foram tomadas com luz paralela e as 
do lado direito sob nicóis cruzados, para colocar em evidência o comportamento birrefringente das inclusões. Considerando que a maior parte das inclusões são incolores e birrefringentes, é provável que esses exemplares correspondam a olivina, que é a fase silicática mais comum em diamantes naturais (Meyer 1987; Harris \& Gurney 1979). A Fotomicrografia (6.1.e) mostra o interior de um diamante com um grande número de defeitos (manchas escuras), conhecidas sob a denominação de carvões. Observa-se que os defeitos possuem orientação cristalográfica correspondente a de planos octaédricos, indicando tratar de clivagem internas. A Fotomicrografia 6.2 coloca em evidência pormenores morfológicos das inclusões, que em geral são idiomorfas e de faces ligeiramente abauladas. A foto inferior mostra também anomalias ópticas circundando as inclusões (hipérboles anômalas), resultantes provavelmente de centros de tensão provocados pela inclusão no hospedeiro. Nota-se ainda o comportamento birrefringente anômalo do diamante. Finalmente, a Fotomicrografia 6.3 apresenta um diamante de $2 \mathrm{~mm}$ talhado na lapidação brilhante contendo jaças e inclusões minerais. A dimensão e a posição desses defeitos (6.3.a) depreciam a pedra reduzindo seu valor no mercado. 
Tabela 6.5 - Inclusões e respectivas cores amostradas em diamantes das regiões de Chapada dos Guimarães (loties CG1, CG2 e CG3), Poxoréu (lotes Px1 e Px2), Diamantino (lote Di1) e Alto Paraguai (lotes AP1, AP2, AP3 e AP4). Legenda: In - incolor, Vevermelho, La-laranja e Pr-preto.

\begin{tabular}{|c|c|c|c|c|c|c|c|c|c|c|c|c|c|c|c|c|c|c|c|}
\hline $\begin{array}{c}\text { Lotes } \\
\mathrm{n} . \text { crist. }\end{array}$ & $\begin{array}{c}C G(1) \\
90\end{array}$ & \multicolumn{2}{|c|}{$\begin{array}{c}C G(2) \\
36 \\
\end{array}$} & \multicolumn{2}{|c|}{$\begin{array}{c}C G(3) \\
107 \\
\end{array}$} & \multicolumn{3}{|c|}{$\begin{array}{r}P \times(1) \\
336 \\
\end{array}$} & \multicolumn{2}{|c|}{$\begin{array}{c}P \times(2) \\
479 \\
\end{array}$} & \multicolumn{2}{|c|}{$\begin{array}{r}\mathrm{Di}(1) \\
268 \\
\end{array}$} & \multirow{2}{*}{\begin{tabular}{|c|}
$\mathrm{AP}(1)$ \\
115 \\
$\mathrm{Pr}$ \\
\end{tabular}} & \multicolumn{2}{|c|}{$\begin{array}{c}\mathrm{AP}(2) \\
388 \\
\end{array}$} & \multicolumn{3}{|c|}{$\begin{array}{c}\mathrm{AP}(3) \\
57 \\
\end{array}$} & \multirow{2}{*}{\begin{tabular}{|r}
$\mathrm{AP}(4)$ \\
480 \\
$\mathrm{Pr}$
\end{tabular}} \\
\hline Crivo (mm & In & $\ln$ & $\mathrm{Pr}$ & In & $\mathrm{Pr}$ & $\ln$ & $\mathrm{Ve}$ & $\mathrm{Pr}$ & In & $\mathrm{Pr}$ & $\ln$ & $\mathrm{Pr}$ & & $\ln$ & $\mathrm{Pr}$ & In & $\mathrm{La}$ & $\mathrm{Pr}$ & \\
\hline$<$ & 0 & 0 & 0 & 0 & 0 & 0 & 1 & 1 & 의 & 16 & 0 & 6 & 0 & 0 & 14 & 1 & 0 & 0 & 5 \\
\hline 1,7 & 0 & 0 & 0 & 0 & 1 & 0 & 이 & 1 & 0 & 12 & 0 & 7 & 8 & 0 & 15 & 0 & 0 & 0 & 4 \\
\hline 1,9 & 3 & 이 & 0 & 0 & 1 & 0 & 0 & 2 & 0 & 11 & 0 & 8 & 1 & 0 & 4 & 1 & 0 & 0 & 0 \\
\hline 2,2 & 3 & o) & 1 & 0 & 1 & 0 & 0 & 9 & 0 & 16 & 0 & 12 & 6 & 1 & 6 & 0 & 0 & 3 & 5 \\
\hline 2,5 & 1 & 0 & 1 & 0 & 0 & 1 & 0 & 8 & 0 & 4 & 1 & 1 & 5 & o & 3 & 0 & 2 & 2 & 0 \\
\hline 2,7 & 0 & 이 & 0 & 1 & 1 & 0 & 0 & 5 & 0 & 4 & 0 & 1 & 3 & 0 & 1 & 0 & 0 & 1 & 3 \\
\hline 3 & 0 & 0 & 3 & 0 & 3 & 0 & 0 & 3 & 0 & 8 & 0 & 6 & 0) & 3 & 0 & 0 & 0 & 0 & 13 \\
\hline 3,3 & 0 & 1 & 0 & 0 & 3 & 0 & 이 & 5 & 0 & 3 & 1 & 5 & 0 & 0 & 6 & 0 & 0 & 0 & 4 \\
\hline 3,6 & 이 & 0 & 0 & 0 & 2 & 0 & 이 & 6 & 1 & 6 & 요 & 0 & 2 & 0 & 3 & 0 & 0 & 0 & 7 \\
\hline 3,9 & 1 & 0 & 0 & 0 & 5 & 0 & 0 & 0 & 0 & 2 & 0 & 1 & 0 & 0 & 2 & 0 & 0 & 0 & 5 \\
\hline 4,1 & 5 & 이 & 0 & 0 & 2 & 0 & 0 & 2 & 0 & 0 & 0 & 0 & 0 & 0 & 3 & 0 & 0 & 0 & 8 \\
\hline 4,3 & 0 & 이 & 0 & 0 & 1 & 0 & 0 & 2 & 0 & 2 & 0 & 1 & 0 & 0 & 0 & 0 & 0 & 0 & 2 \\
\hline$>$ & 0 & 0 & 0 & 0 & 4 & 0 & 0 & 3 & 0 & 8 & 0 & 0 & 0 & 0 & 4 & 0 & 0 & 0 & 5 \\
\hline total & 13 & 1 & 5 & 1 & 24 & 1 & 11 & 47 & 1 & 92 & 2 & 48 & 25 & 4 & 59 & 2 & 2 & 6 & 61 \\
\hline
\end{tabular}




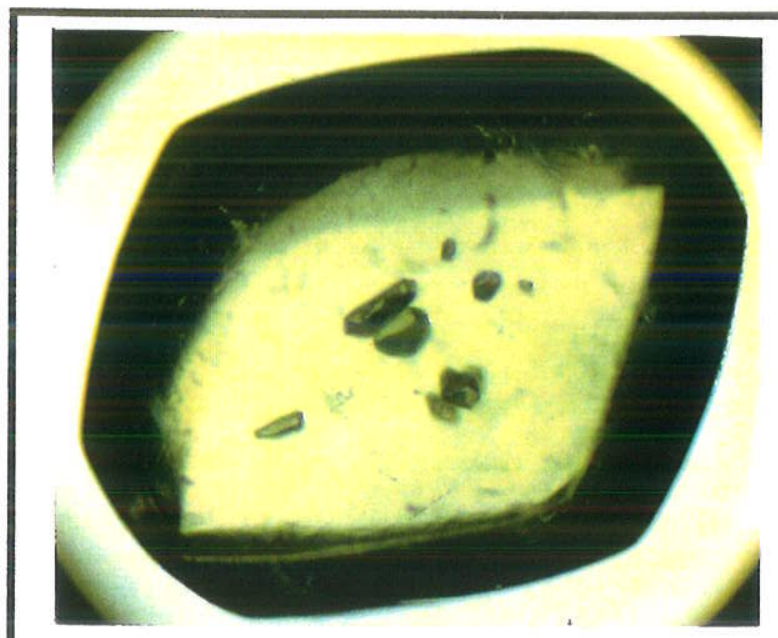

a

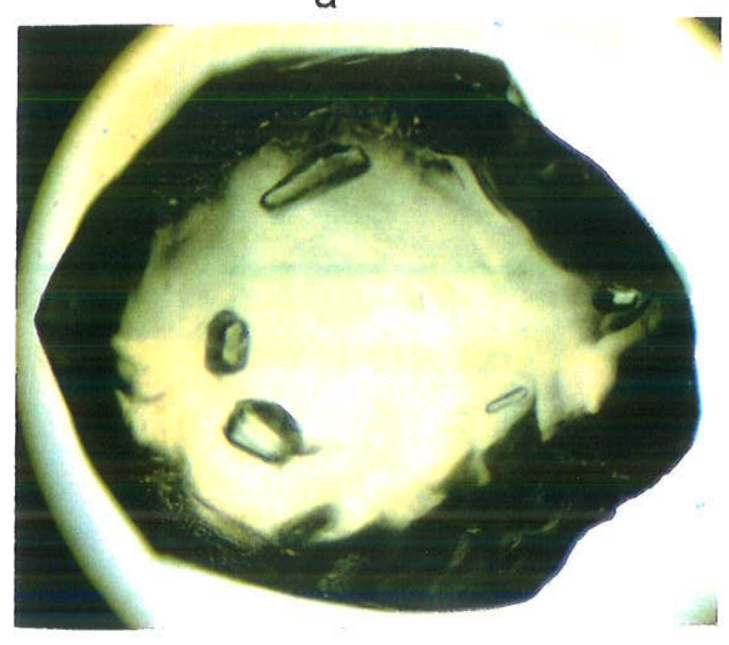

C

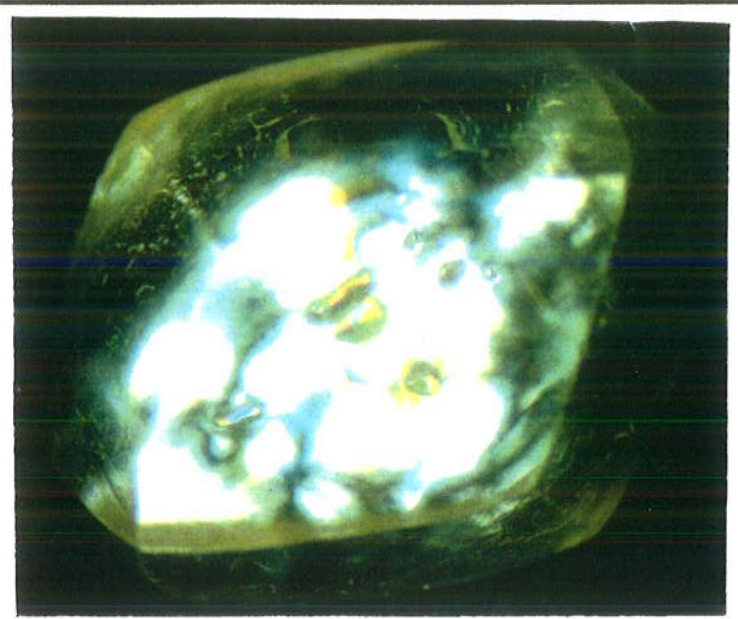

b

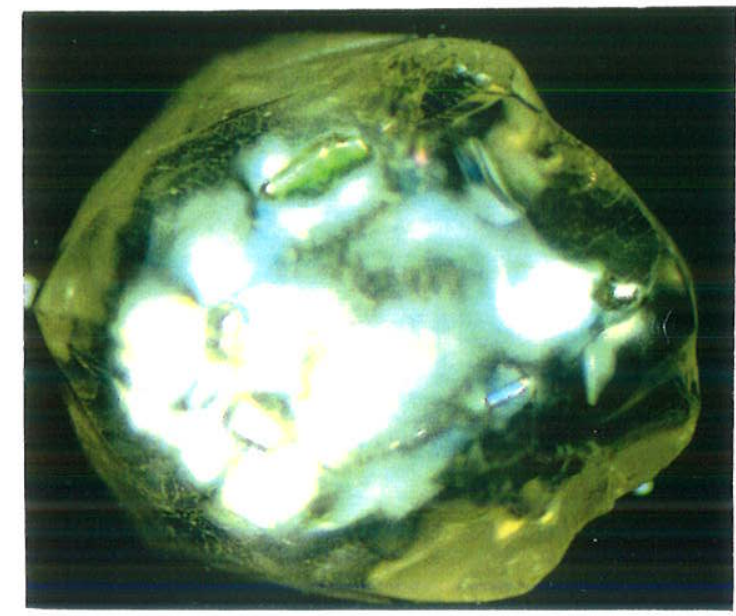

d

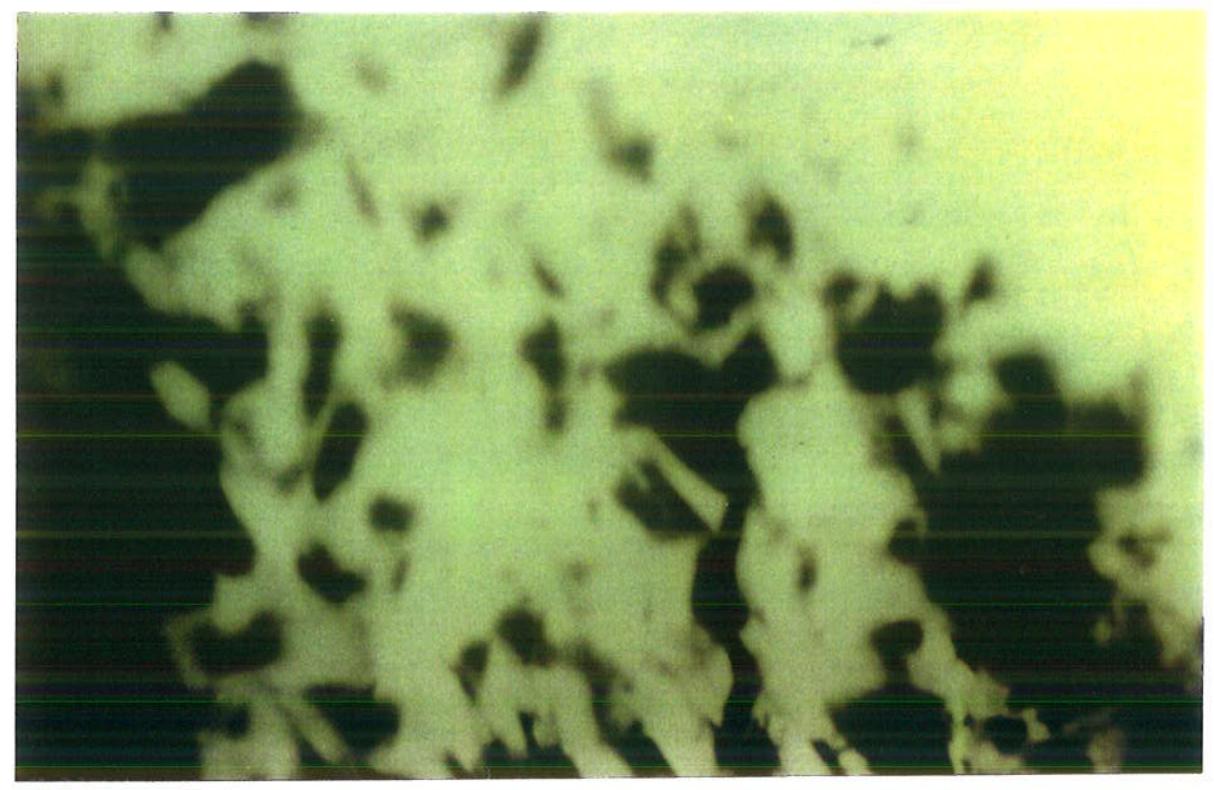

Fotomicrografia 6.1 - Inclusões minerais, provavelmente olivina (incolor, birrefringente em diamantes rombododecaédrico e transicional, sob nicóis paralelos e cruzados, respectivamente $(a, b)$ e $(c, d)$. A foto anterior (e) mostra o interior de um diamante repleto de manchas escuras carvões onde está bem evidente a orientação desses defeitos (planos octaédricos). 

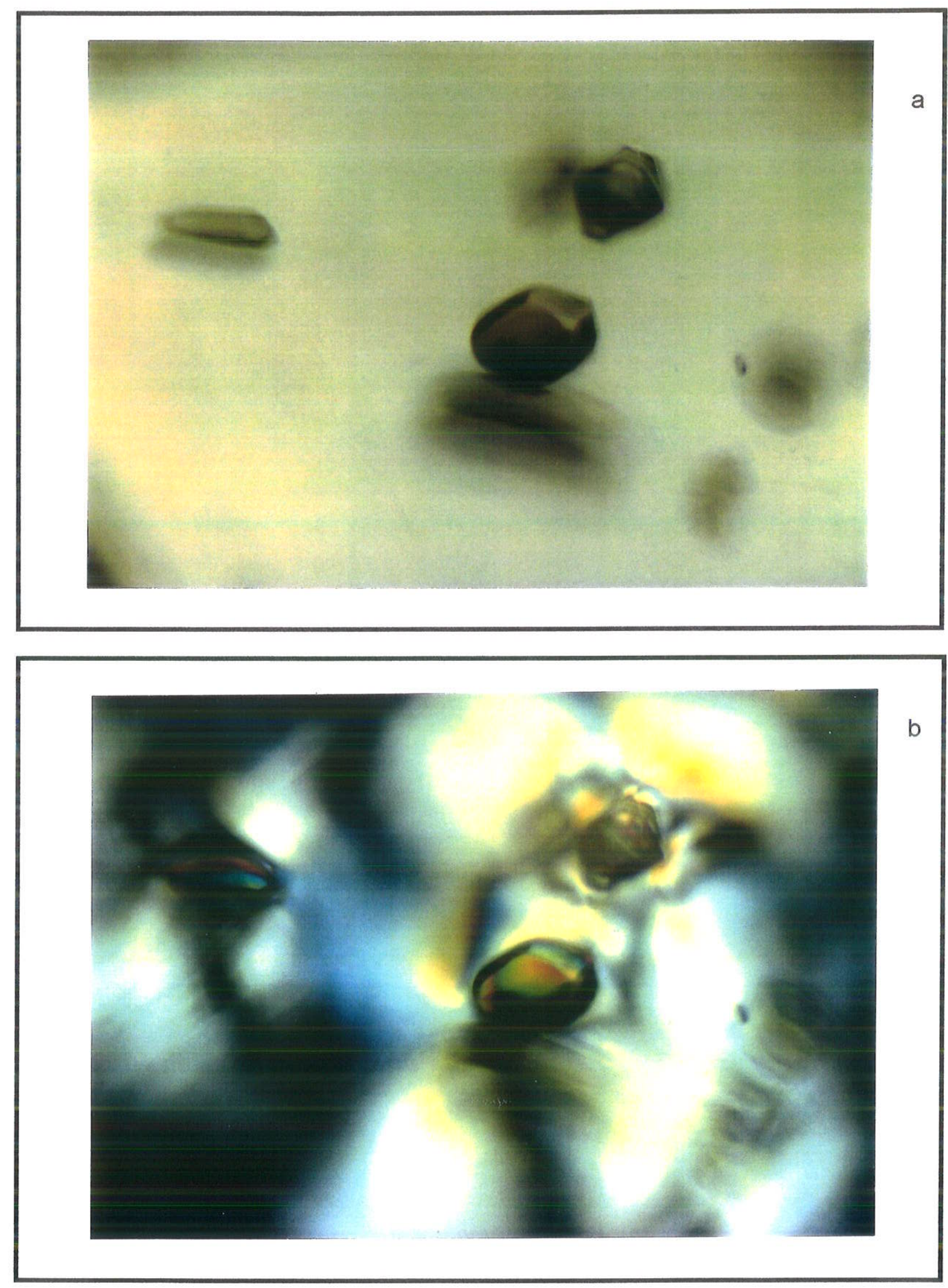

Fotomicrografia 6.2 - Grupo de inclusões idiomórficas situadas em níveis distintos do diamante hospedeiro: a) nicóis paralelos e aumento de 100x; b) mesma situação anterior sob nicóis cruzados. Notar as hipérboles anômalas em torno das inclusões resultantes dos centros de tensão do diamante. 

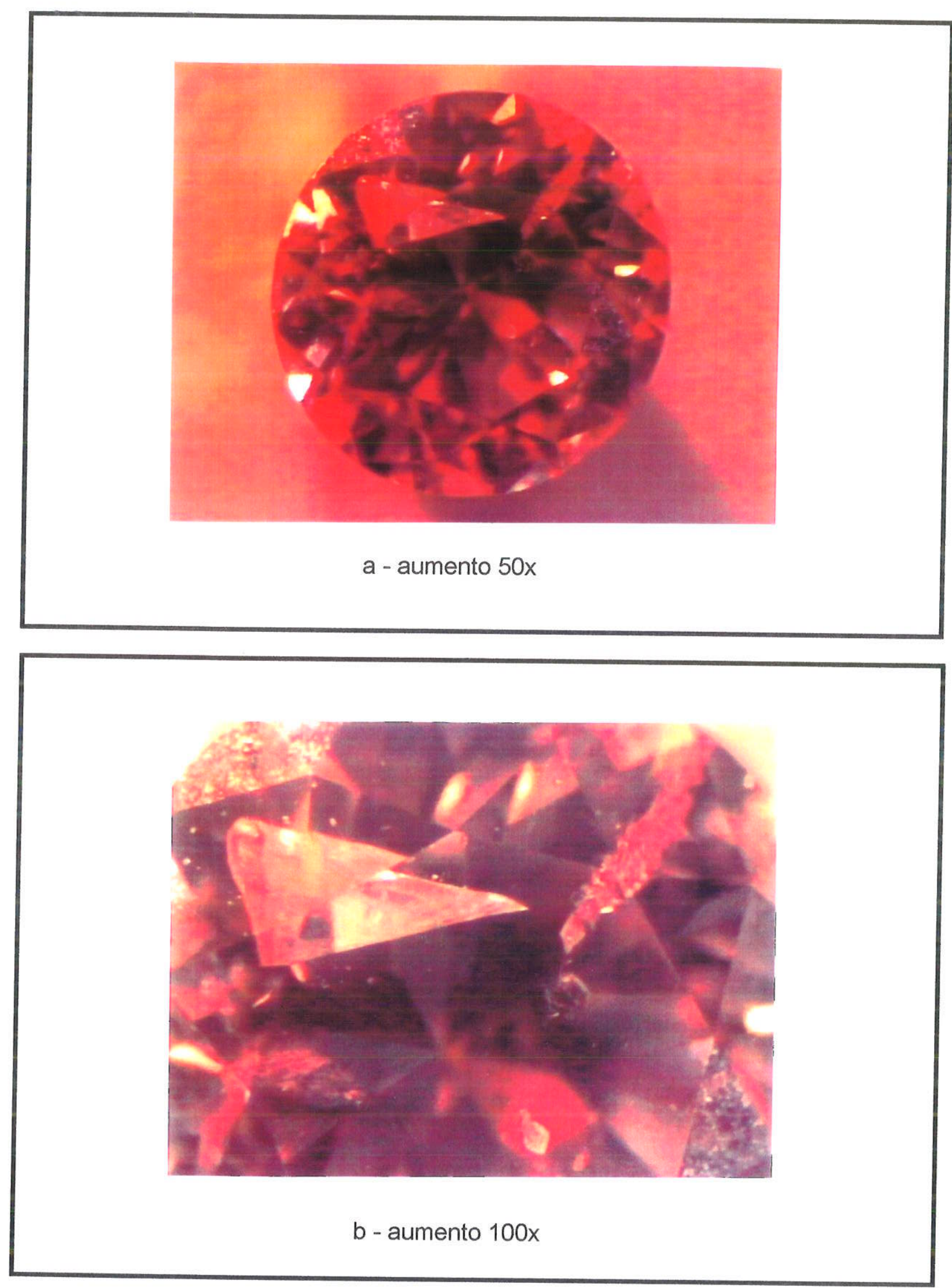

Fotomicrografia 6.3 - Inclusões minerais e defeitos cristalinos (jaças) em um diamante lapidado no talhe brilhante. 


\section{CLASSIFICAÇÃO COMERCIAL DO DIAMANTE}

As primeiras classificações do diamante baseavam-se exclusivamente no seu peso, uma vez que esse era o único fator importante no comércio. Porém, com o avanço da ciência e da tecnologia e com a necessidade de se preservar a "raridade", outros critérios físicos foram sendo adotados gradativamente. A definição da cor macroscópica à vista desarmada e, posteriormente, a utilização de lupas trouxeram novos elementos à classificação do diamante (Bruton 1978). A formulação dos critérios de classificação ou avaliação para serem seguidos pelos comerciantes, tornou-se então fundamental. Além disso, a unificação e a padronização da nomenclatura destes critérios foram decisivos para que eles se tornassem práticos e confiáveis.

A classificação mais simplificada divide os diamantes em dois grupos: a) tipo indústria que reune todas as pedras desprovidas de qualidade para serem utilizadas como gemas e b) tipo gema, que são as pedras dotadas de propriedades especiais adequadas para serem lapidadas. Levinson et al. (1992) formalizou essa classificação em diamantes lapidáveis cuttable e tipo indústria.

As classificações examinadas nos capítulos anteriores basearam-se nas propriedades físicas, ou seja na granulometria, forma, cor, presença de inclusões minerais e fluorescência (Tabelas 2.1 e 2.2), e tiveram por objetivo uma análise científica das propriedades do diamante. Como será observado nos ítens subsequentes, as classificações gemológicas baseiam-se também em algumas propriedades físicas específicas, particularmente na cor, pureza, peso e lapidação. Além disso, elas incluem também uma série de normas e procedimentos complementares adaptados para atender o comércio do diamante no mundo. Como resultado o diamante é a unica gema que possui um sistema padronizado de classificação, que é adotado e praticado pelos principais centros gemológicos da atualidade. Nessas condições, os certificados de autenticidade fornecidos pelos laboratórios credenciados são semelhantes entre si, sendo aceitos em todos os países do mundo.

Os principais sistemas de nomenclatura gemológica são regidos por associações internacionais entre as quais se destacam o Gemological Institute of America (GIA) usado nos Estados Unidos da America, a Confédération Internationale de la Bijouterie, Joallerie, Orfèvrerie des Diamants, Parles et Pierres (CIBJO) usado na 
Áustria, Bélgica, Canadá, Dinamarca, Finlândia, França, Grã Bretanha, Itália, Japão, Holanda, Noruega, Espanha, Suécia, Suíça, EUA e Alemanha; o Scandinavian Diamond Nomenclature and Grading Standards (ScanDN) usado na Suécia, Noruega, Dinamarca e Finlândia; o American Gem Society (AGS) também usado nos Estados Unidos da América; o Deutsche Gemmologische Gesellschaft (DGemG) usado na Alemanha; O Hoge Raad Voor Diamant (HRD) usado na Bélgica e, finalmente o International Diamond Council (IDC). Estes sistemas de nomenclatura apresentam algumas divergências quanto aos conceitos de alguns fatores, mas conduzem a um resultado semelhante na avaliação da qualidade do diamante. Cabe aqui ressaltar que os certificados brasileiros, em geral seguem a nomenclatura do GIA.

\subsection{Diamante lapidado}

A avaliação da qualidade do diamante lapidado baseia-se fundamentalmente em quatro fatores conhecidos como os quatro "c's", que são: carat (peso), color (cor), clarity (pureza) e cut (lapidação). No caso dos diamantes brutos, o último aspecto é substituído pela forma do cristal.

As classificações usadas no mercado mudam constantemente em função da demanda e da produção de diamantes. Como nas últimas décadas o poder aquisitivo teve uma redução em escala mundial, houve um aumento na procura das pedras menos valiosas, ou seja, aquelas de qualidade gemológica inferior. Desse modo, os diamantes do tipo "indústria superior", passaram a ser tratados como lapidáveis nas classes inferiores de pureza. Observa-se portanto, que a classificação do diamante é o primeiro passo para determinar qual será seu valor no mercado.

O sistema utilizado pelo Gemological Institute of America, referido simplesmente pela sigla GIA, é o mais utilizado no comércio internacional de diamante lapidado. Os demais sistemas, seguem de perto os critérios adotados pelo GIA. Esse sistema, também denominado Diamond Grading, foi introduzido em 1953 e ao longo dos anos foi sendo modificado gradualmente de acordo com as necessidades do mercado.

A classificação de um diamante gemológico já lapidado é feita segundo procedimentos rigorosos baseados nos 4c's acima mencionados. Será apresentada nos itens subseqüentes, uma discussão resumida dos critérios usados na avaliação da cor, da pureza, da lapidação e do peso, usados no GIA. É pertinente destacar que o 
preço do diamante depende da avaliação final combinada desses quatro elementos. Se houver um erro em qualquer um desses fatores, o preço da pedra pode subir ou cair substancialmente.

\subsubsection{Classificação da cor}

A avaliação da cor macroscópica envolve decisões de quanto a cor da pedra se aproxima do incolor colorless. No entanto, a maioria dos diamantes apresentam traços das cores amarelo e castanho, sendo o amarelo a cor mais freqüente entre os diamantes naturais. Excetuando-se os de cor fantasia azul, rosa, púrpura, violeta, laranja e vermelho, os incolores são os mais valiosos (Diamond Grading, GIA 1992). Durante a avaliação deve-se observar o matiz e a profundidade da cor, que é uma combinação de tom e saturação, conforme foi discutido no Capítulo 6.

Existem diamantes praticamente de todas as tonalidades de cores e como já foi dito, os amarelos são os mais freqüentes. Portanto, a cor do diamante é determinada mediante a comparação visual entre a pedra em exame e as de uma coleção graduada. Esta coleção, conhecida como "Série Amarela" é a forma de classificação mais importante do comércio, sendo constituída por um conjunto de oito diamantes padrão de tamanhos semelhantes, desprovidos de inclusões, variando de cor desde o incolor até o amarelo. A transição entre as cores não é claramente definida pelo master color. No Brasil, existe o sistema oficial da Associação Brasileira de Normas Técnicas (ABNT) que instituiu também uma escala de coloração para diamantes lapidados em uso desde 1991.

No sistema do GIA, a cor é descrita por uma letra que varia de D a Z. A cor D corresponde a um tipo de diamante absolutamente incolor enquanto a letra $Z$ a um diamante acentuadamente colorido, geralmente de cor amarela ou castanha. Assim sendo, cada letra representa um aumento gradual na intensidade do amarelo, conforme está mostrado na Tabela 7.1. A referida tabela contém também, para efeito de comparação as principais categorias referentes a cor dos sistemas classificatórios CIBJO, HRD e DNPM.

Qualquer outra cor além do incolor, amarelo, castanho ou cinza será considerada "cor excepcional" de que são exemplos os diamantes vermelho, azul, amarelo intenso, verde, rosa, lilás e roxo (tipos fancy), independentemente de sua 
Tabela 7.1 - Classificação da cor segundos os sistemas de classificação do GlA (1991), CIBJO, HRD e do DNPM (1991).

\begin{tabular}{|c|c|c|c|}
\hline GIA & CIBJO & HRD & DNPM \\
\hline $\mathrm{D}$ & Exceptional white $(+)$ & Excepcional white + & $\begin{array}{c}\text { Excepcionalmente incolor } \\
\text { extra }\end{array}$ \\
\hline$E$ & Exceptional white & Excepcional white & Excepcionalmente incolor \\
\hline $\mathrm{F}$ & Rara white (+) & Rare white + & Perfeitamente incolor extra \\
\hline $\mathrm{G}$ & Rare white & Rare white & Perfeitamente incolor \\
\hline $\mathrm{H}$ & White & White & Incolor \\
\hline 1 & Sliahtly tinted white. & Slightly tinted white $\uparrow$ & Cor perceptível \\
\hline J & Silgnuy inted white. & Slightly tinted white 2 & Cor visível \\
\hline K & Tinted white & Tinted white 1 & Cor acentuada \\
\hline$L$ & & Tinted white 2 & Cor levemente amarelada \\
\hline $\mathrm{M}, \mathrm{N}$ & Tinted colour & Tinted color 1 & Cor amarelada \\
\hline $\mathrm{O}, \mathrm{P}$ & & Tinted color 2 & Cor amarela \\
\hline $\begin{array}{l}\mathrm{Q}, \mathrm{R} \\
.\end{array}$ & & Tinted color 3 & Cor acastanhada \\
\hline$Z+$ & Fancy diamonds & & \\
\hline
\end{tabular}

Tabela 7.2 - Classificação das classes de pureza segundo os sistemas de classificação do GIA (1991), CIBJO e do DNPM (1991).

\begin{tabular}{|c|c|c|c|}
\hline Grau de limpidez & $\mathrm{GIA}^{*}$ & CIBJO & DNPM \\
\hline Totalmente livre de inclusões. & FL IF & LC & Perfeito \\
\hline $\begin{array}{l}\text { Inclusões minúsculas, muito } \\
\text { difíceis de serem observadas } \\
\text { com lupa de 10x. }\end{array}$ & VVS1 VVS2 & VVS1 VVS2 & $\begin{array}{l}\text { Imperfeições } \\
\text { mínimas }\end{array}$ \\
\hline $\begin{array}{l}\text { Inclusões pequenas, difíceis } \\
\text { de serem observadas com } \\
\text { lupa de } 10 \mathrm{x} \text {. }\end{array}$ & VS1 VS2 & VS1 VS2 & $\begin{array}{l}\text { Imperfeições } \\
\text { pequenas }\end{array}$ \\
\hline $\begin{array}{l}\text { Inclusões evidentes com a } \\
\text { lupa, porém difíceis de serem } \\
\text { vistas em } \\
\text { macroscópica. }\end{array}$ & Sl & Sl & $\begin{array}{l}\text { Imperfeições } \\
\text { médias }\end{array}$ \\
\hline $\begin{array}{l}\text { Inclusões grandes e/ou } \\
\text { freqüentes, que reduzem o } \\
\text { brilho da pedra; são fáceis de } \\
\text { serem vistas em escala } \\
\text { macroscópica. }\end{array}$ & 11 & Piqué 1 & \multirow[t]{3}{*}{$\begin{array}{l}\text { Imperfeições } \\
\text { grandes }\end{array}$} \\
\hline \multirow[t]{2}{*}{$\begin{array}{l}\text { Cristais de qualidade não } \\
\text { gemológica (tipo indústria). }\end{array}$} & 12 & Piqué II & \\
\hline & 13 & Piqué Ill & \\
\hline
\end{tabular}


intensidade (Quitete et al. 1994). Com relação a estes diamantes, utiliza-se um sistema de graduação de cores denominado GIA-GTL (GIA Gem Trade Laboratory), que contém 27 matizes associado com o sistema de Munsell (1976). Esse sistema é formado por uma sistemática e bem distribuida classificação de cores contendo 1.500 padrões na forma de plaquetas, utilizadas para identificar a tonalidade e a saturação da cor do diamante (King et al. 1994). Neste sistema é utilizado um código para a determinação da cor, composto por uma letra e dois números, onde a letra representa a cor, o primeiro número representa o brilho e o segundo número a saturação, ou o quanto a cor é viva. Os preços atribuídos aos diamantes coloridos dependem mais da raridade da cor do que da sua pureza, peso e lapidação. Existe também o conjunto de cores do IDC que foi composto em 1977 pelo World Federation of Diamond Bourses, pelo International Diamond Manufacturers Association e pelo CIBJO.

Outro procedimento para determinar a cor do diamante gemológico é pela utilização de aparelhos gemológicos, como por exemplo o Colormaster. Esta forma de classificação é mais utilizada em centros gemológicos. No comércio, por motivos práticos, a comparação da cor através de padrões pré-estabelecidos é a mais comum.

\subsubsection{Classificação da pureza}

O grau de pureza é representado por uma escala que abrange cristais perfeitos a imperfeitos. A pureza de uma pedra é classificada em função das inclusões e de suas características externas. As inclusões em gemologia abrangem todas as formas de defeitos internos perceptíveis (ABNT 1991) e constituem feições importantes para a diferenciação entre as gemas naturais e sintéticas.

Na gemologia, o termo inclusão abrange um conjunto amplo de feições externas e internas entre as quais se incluem as inclusões cristalinas representadas por minerais variados, superfícies de clivagens ou de fraturas escuras (carvão), superfícies de clivagens ou de fraturas claras (jaças), zoneamentos, superfície de tensão, linhas e planos de geminação, linhas e planos de crescimento, falta de homogeneidade óptica, entre outras (Gubelin \& Koivula 1984). As feições externas do cristal, são representadas por riscos, fraturas, buracos, restos de faces do cristal bruto e linhas de crescimento. Durante o processo da determinação do grau de pureza é necessário levar em conta não só a presença de defeitos internos e externos mas também o 
tamanho, o número, a posição, a natureza, a cor e o relevo das inclusões e dos defeitos. Estas observações devem ser feitas em conjunto tanto na pedra bruta para estimar o tamanho e as características resultantes da lapidação, bem como na pedra lapidada durante a avaliação de seu valor.

A avaliação do grau de pureza é referida sempre em relação a um aumento determinado, padronizado em 10 vezes. Nessa operação, utiliza-se uma lupa de 10x, aplanática e acromática, uma vez que a figura observada não deve apresentar deformações nas bordas e nem estar rodeada por contornos coloridos.

Segundo o GIA, as classes de pureza são $\mathrm{FI}, \mathrm{IF}, V S_{1}, V \mathrm{VS}_{2}, V_{1}, V_{2}, \mathrm{SI}_{1}, \mathrm{SI}_{2}$, $I_{1}, I_{2}$, e $I_{3}$ (Tabela 7.2). A classe FI flawless indica uma gema quase perfeita com no máximo alguns defeitos insignificantes que de modo algum prejudicam a beleza da pedra. Já a classe $\mathrm{I}_{3}$, imperfect representa o limite entre diamantes de natureza gemológica e diamantes de uso industrial. Poucos diamantes são absolutamente isentos de impurezas flawless. Entretanto, certas pedras de boa qualidade, porém portadoras de pequenos defeitos, podem transformar-se em pedras de excelente qualidade após a eliminação dos defeitos durante a lapidação. Obviamente, durante esses processos a pedra original sofre uma perda de peso reduzindo seu valor inicial.

Na maior parte das tabelas de preços, as maiores diferenças de preço para uma

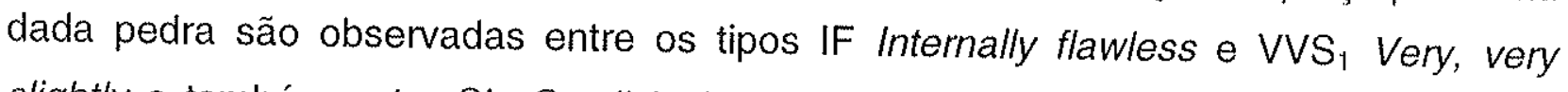
slightly e também entre $\mathrm{Sl}_{2}$ Small inclusion e $\mathrm{I}_{1}$ Inclusion. Em todos os tamanhos o preço dá um grande salto entre o tipo FI Flawless e IF Internally flawless. Entretanto, diamantes pertencentes à categoria Flawless são tão raros que não participam do comércio diário dessa gema.

Apesar de todas as padronizações, existem algumas diferenças nos sistemas internacionais no tocante à graduação da pureza, tendo por um lado o conceito europeu e por outro o americano. No sistema europeu, a avaliação da pureza leva em conta somente as características internas da pedra, ficando as características externas incluídas na avaliação da lapidação. Por outro lado, no sistema americano a avaliação da pureza leva em conta as características tanto internas quanto externas. Esta diferença não tem influência na fixação do preço uma vez que os europeus consideram as características externas, como características de lapidação (Souza 1984). 


\subsubsection{Classificação da lapidação}

Os diamantes lapidados são classificados de acordo com as suas proporções, dimensões e qualidade de sua lapidação. As proporções da pedra compreendem o seu tamanho, a relação entre os ângulos de suas faces, bem como os diferentes elementos que compoem o desenho da pedra. O acabamento do processo de lapidação inclui o polimento, a colocação e os detalhes das facetas, levando em conta os desvios que ocorrem na simetria. O corte afeta o peso do cristal bruto e as propriedades ópticas da pedra lapidada. Portanto, a lapidação trata das proporções da pedra, sendo responsável pelo britho e pelo "fogo" que emanam da pedra lapidada. Os técnicos referem-se à "pedras vivas"e a "pedras mortas", designando com essas expressões a presença ou a falta de vida (brilho e efeito arco-iris). A lapidação perfeita requer um equilíbrio entre estas características tornando desta forma a pedra mais valiosa.

A Figura 7.1 apresenta de forma simplificada, os principais tipos de lapidação empregados no diamante. O talhe brilhante, ou lapidação redonda é de longe o mais importante no comércio do diamante (Bruton 1984). Outros tipos de lapidação utilizados incluem os talhes esmeralda, navete, gota, oval, coração e baguete. A lapidação é um trabalho que combina técnica e arte, uma vez que cada mineral se destaca mais com um certo tipo de lapidação do que com outro. No caso do diamante a lapidação preferida é o brilhante.

A lapidação abrange quatro operações que são clivagem, serragem, corte e polimento das facetas. A clivagem envolve a quebra da pedra segundo planos paralelos segundo à face octaédrica. Essa operação é realizada com o propósito de isolar a parte da pedra que contem inclusões, obtendo-se desta forma uma parte limpa adequada para a lapidação. Após a clivagem, a pedra é serrada em duas peças, que podem ser paralelas preferencialmente às faces de cubo e rombododecaedro, uma vez que na direção do octaedro a dureza é a máxima possível. A serragem pode ser feita em roda metálica embebecida com pó de diamante ou a laser. A vantagem de se usar - laser é que a pedra pode ser serrada em qualquer direção, fato que não ocorre na mesa convencional, uma vez que a roda diamantada só corta nas direções de menor dureza. Após a divisão da pedra as faces são polidas em estágios de acordo com o tipo de lapidação escolhida (brilhante, esmeralda, navete, oval, gota, coração, etc.). No processo de lapidação, aproveita-se de 40 a $55 \%$ do peso das pedras brutas de boa 


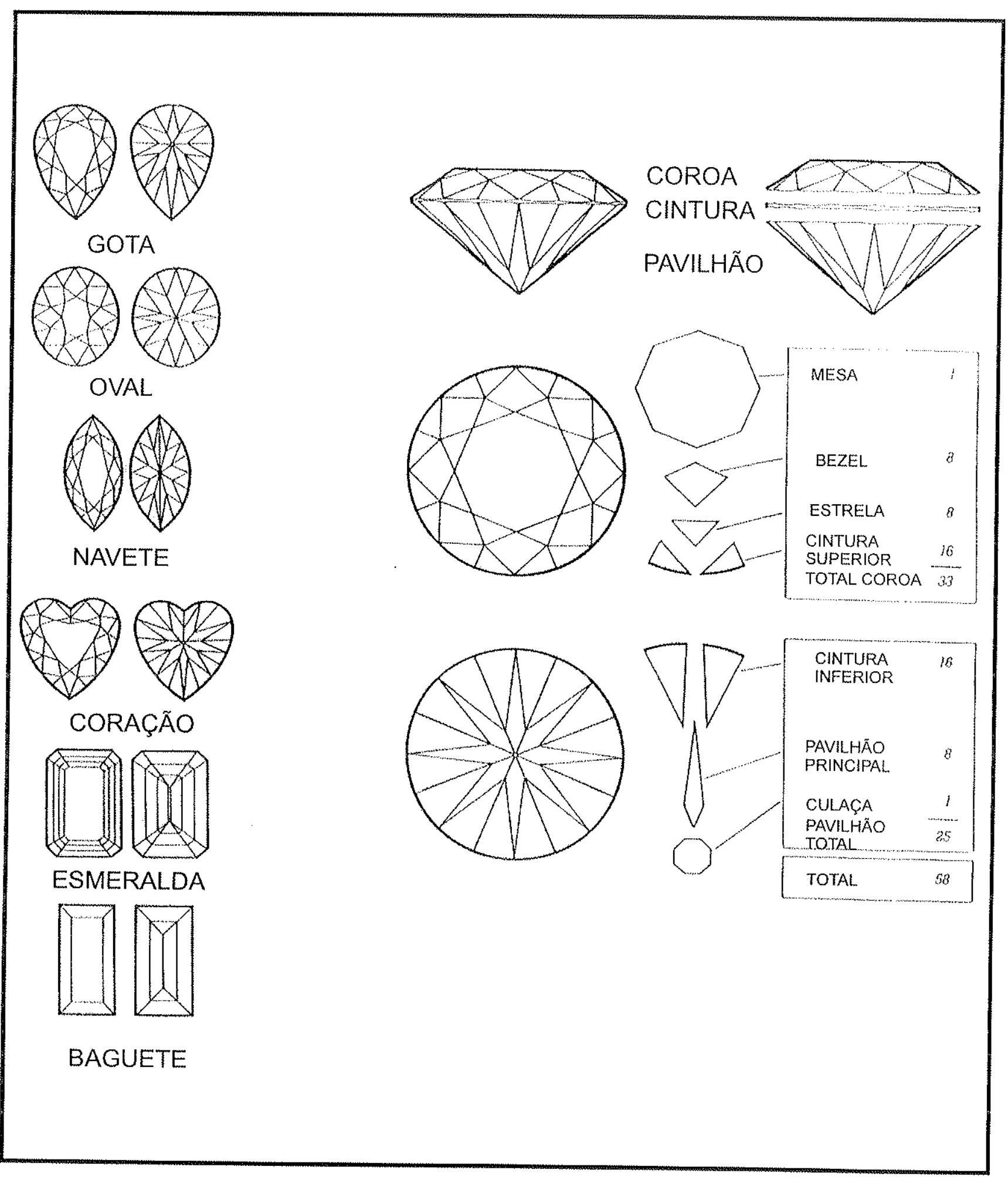

Figura 7.1 - Esquema simplificado do talhe brilhante. Outras lapidações utilizadas são gota, oval, navete, coração, esmeralda e baguete. 
qualidade, ou seja, pedras com formas de octaedros e rombododecaedros proporcionados. No caso de pedras de qualidade inferior o índice de aproveitamento oscila em torno de $25 \%$, ou menos, dependendo do grau de regularidade da pedra (Romboust 1997). A Figura 7.2 ilustra a influência da forma original da pedra na lapidação. Observa-se que algumas formas cristalográficas como o octaedro e o rombododecaedro são mais favoráveis à lapidação brilhante. Outras formas como o rombododecaedro alongado favorecem as lapidações oval e navete. Pedras irregulares podem ser aproveitadas usando-se outros tipos de lapidação tais como gota, navete, baguete, entre outras.

Os desvios no grau de acabamento dos diferentes tipos de lapidação do diamante muitas vezes não são devidos ao descuido ou à falta de habilidade do lapidário. Muitas vezes esses defeitos ocorrem propositalmente procurando-se conseguir uma pedra de maior peso, aumentando desse modo o seu valor. Este conceito é errado pois a lapidação deve ser planejada com o objetivo de se obter um acabamento perfeito com a menor perda de peso possível.

A avaliação da qualidade da lapidação também pode ser feita utilizando-se um aparelho gemológico denominado Proporcionômetro. A pedra é colocada dentro do aparelho e projeta uma imagem que é comparada com o corte ideal de uma lapidação brilhante. Qualquer defeito relativo à variações nos ângulos de lapidação, dimensões principais das facetas e número de facetas extras, entre outros defeitos possíveis, são imediatamente anotados e computados para a avaliação do preço.

A lapidação é um fator que influi menos nas classificações quando comparada com a cor e a pureza. Ela assume um papel mais decisivo no caso de pedras grandes e raras. Esse fato pode ser explicado levando em conta que a maior parte dos comerciantes possuem um pequeno treinamento nas técnicas de lapidação. O GIA classifica a lapidação em quatro classes onde são levados em conta as proporções entre os elementos da lapidação (mesa, coroa, cintura e pavilhão), conforme está mostrado na Tabela 7.3. As pedras da classe 1 possuem um valor aproximadamente $15 \%$ maior do que os da classe 2 , mesmo que o peso, a cor e a pureza sejam os mesmos. O mesmo ocorre em relação à classe 2 para a 3 , onde o valor varia de 5 a $15 \%$ a menos. Finalmente na classe 4 observa-se que o valor pode chegar até $50 \%$ a menos do que na classe 2 (GIA 1991). 


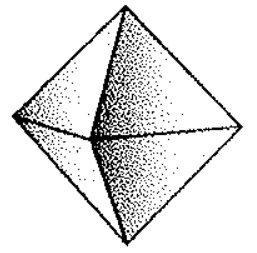

Octaedro

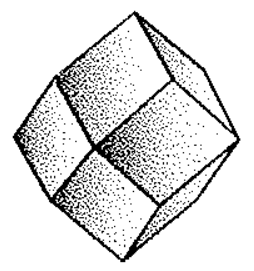

Rombododecaedro

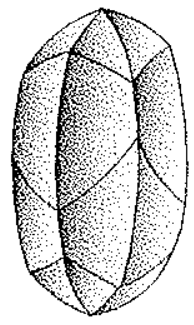

Rombododecaedro alongado

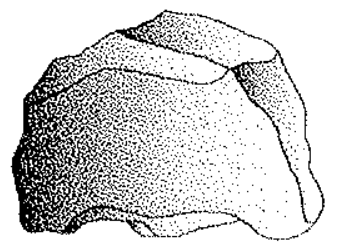

Forma irregular

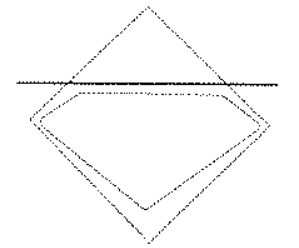

Aproveitamento

na lapidação
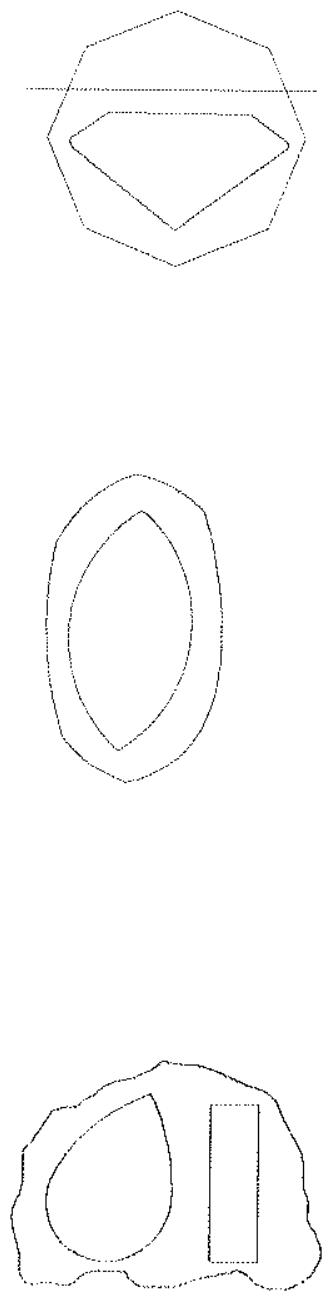

Gota

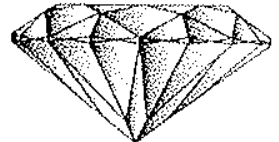

Brilhante

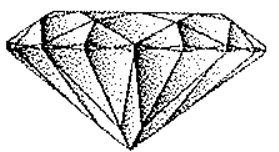

Brilhante

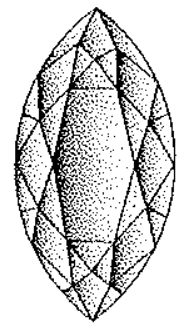

Navete

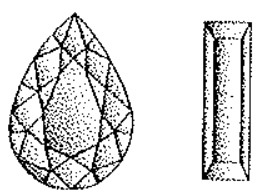

Baguete

Figura 7.2 - Influência da morfologia cristalina no tipo de lapidação. A escolha do tipo de lapidação depende também de outros fatores físicos tais como presença e posição de defeitos cristalinos, inclusões minerais, plano de geminação e valor relativo entre os talhes possiveis. 
Tabela 7.3 - As quatro classes de lapidação usadas no mercado de diamante lapidado, segundo o GIA (1991).

\begin{tabular}{|c|c|c|c|c|}
\hline Classe & 1 & 2 & $3^{*}$ & $4^{* *}$ \\
\hline mesa & $53-60 \% * *$ \\
coroa & $34-35^{\circ}$ & $61-64 \%$ & $65-70 \%$ & $+70 \%$ \\
\hline rondiz & média & fina/grossa & $\begin{array}{c}\text { muito fina/ } \\
\text { muito grossa }\end{array}$ & $\begin{array}{c}\text { extremamente fina/ } \\
\text { extremamente grossa }\end{array}$ \\
\hline pavilhão & $43 \%$ & $42-44 \%$ & $\begin{array}{c}41-46 \% \\
\text { levemente } \\
\text { grande }\end{array}$ & $\begin{array}{c}-41 /+46 \% \\
\text { culassa }\end{array}$ \\
\hline nerihum & médio & médio & pobre \\
\hline
\end{tabular}

* A classe 3 inclui também pedras com 51 ou $52 \%$ de mesa, ou com ângulo de $37^{\circ}$.

** A clase 4 inclui também pedras com mesas menores que $51 \%$, ângulos de coroa maiores do que $37^{\circ}$, ou variações maiores de simetria.

${ }^{* * *}$ A tabela de tamanhos para a classe 1 sobe para 61 ou $62 \%$ em pedras abaixo de 0,50 ct.

Tabela 7.4 - Determinação do peso do diamante lapidado a partir do diâmetro da cintura da pedra (praça).

\begin{tabular}{|c|c|c|c|}
\hline Diâmetro em mm & Peso aproximado ct & Diâmetro em mm & Peso aproximado em ct \\
\hline 1,3 & 0,01 & 2,8 & 0,08 \\
\hline 1,7 & 0,02 & 2,9 & 0,09 \\
\hline 1,8 & & 3,0 & 0,10 \\
\hline 1,9 & & 3,1 & 0,11 \\
\hline 2,0 & 0,03 & 3,2 & 0,125 \\
\hline 2,1 & & 3,3 & 0,14 \\
\hline 2,2 & 0,04 & 3,4 & 0,15 \\
\hline 2,3 & & 3,5 & 0,16 \\
\hline 2,4 & 0,05 & 3,6 & 0,17 \\
\hline 2,5 & & 3,7 & 0,18 \\
\hline 2,6 & 0,06 & 3,8 & 0,20 \\
\hline 2,7 & 0,07 & & \\
\hline
\end{tabular}




\subsubsection{Determinação do peso}

Assim como as demais gemas, o diamante é medido e avaliado em quilates (ct), sendo $1 \mathrm{ct}=200 \mathrm{mg}=1 / 5 \mathrm{~g}$. De acordo com as normas internacionais essa unidade deve ser indicada com duas casas decimais. No comércio o quilate é dividido em 100 partes, onde cada parte desta divisão centesimal é denominada de ponto. Deste modo, $1 \mathrm{ct}=100$ pontos ou 1 ponto $=0,01 \mathrm{ct}$.

O peso exato do diamante pode ser obtido através de balanças de precisão que fornecem a leitura direta. O peso aproximado, por outro lado, pode ser obtido através de um calibrador milimétrico, que por sua vez, baseia-se nas partes componentes da pedra, ou seja diâmetro, altura e ângulos entre as facetas principais. Existe uma relação aproximada entre o peso e o diâmetro principal da pedra (praça), conforme está mostrado na Tabela 7.4. Observa-se que para cada valor do diâmetro dado em milímetro, existe um valor correspondente em quilates. Essa relação é usada rotineiramente pelos gemólogos experientes na avaliação de grandes lotes de diamante, os quais pela simples inspeção visual avaliam rapidamente o peso de cada diamante componente do lote. Tratando-se de cristais lapidados segundo os tipos brilhante, oval, coração, baguete, entre outras, e estando a peça montada, existem fórmulas para estimar o peso que podem ser encontradas no Diamond Grading do GIA (1991).

O GIA distribui a classificação do peso em intervalos, sendo esse procedimento adotado também pelas tabelas de preços usadas no comércio (Rapaport e The Guide). Os pesos mais populares no comércio são 0,25; 0,50 e 0,75 ct. A Tabela 7.5 reune as classes de pesos usadas na avaliação de brilhantes e outros talhes de lapidação

Os demais sistemas classificatórios, como já foi mencionado, são semelhantes em linhas gerais ao do GIA (Tabelas 1 e 2), e não serão tratados nesse trabalho. $O$ resultado da classificação de um diamante é apresentado sob a forma de Certificado de Autenticidade, sendo emitido por gemólogos de grande experiência. Com base na classificação do diamante apoiada nos 4c's, obten-se o valor comercial da pedra, seguindo-se os procedimentos constantes das tabelas de preços internacionais.

As duas tabelas mais utilizadas no comércio atualmente são a Rapaport e a The Guide, publicadas nos Estados Unidos da América. Ambas fornecem listas de preços para os principais tipos de lapidação do diamante, levando em conta, cada uma delas, 
as especificidades do mercado. Por exemplo, o Rapaport não inclui preços para diamante de cor fantasia, os quais podem ser obtidos nas listas do The Guide. Além disso, as listas do Rapaport são específicas para pedras de lapidação perfeita não levando em conta pedras com defeito de lapidação. Já o The Guide apresenta listas de preços que variam em função dos defeitos de lapidação. De um modo geral, tanto o Rapaport como o The Guide são constituídos por um conjunto de tabelas que relacionam a cor macroscópica, o peso e a forma da lapidação. A reprodução destas tabelas mesmo que de forma ilustrativa não é permitida.

Tabela 7.5 - Classes de peso em ct para a lapidação brilhante e outras formas de lapidação, usadas no GIA (1991) e nas listas de preços Rapaport (1999) e The Guide (1998).

\begin{tabular}{|c|c|}
\hline Lapidação brilhante & Outras formas de lapidação \\
\hline $0,01-0,03$ & - \\
\hline $0,04-0,07$ & - \\
\hline $0,08-0,14$ & - \\
\hline $0,15-0,17$ & - \\
\hline $0,18-0,22$ & $0,18-0,22$ \\
\hline $0,23-0,29$ & $0,23-0,29$ \\
\hline $0,30-0,37$ & $0,30-0,37$ \\
\hline $0,38-0,45$ & $0,38-0,45$ \\
\hline $0,46-0,49$ & $0,46-0,49$ \\
\hline $0,50-0,69$ & $0,50-0,69$ \\
\hline $0,70-0,89$ & $0,70-0,89$ \\
\hline $0,90-0,99$ & $0,90-0,99$ \\
\hline $1,00-1,49$ & $1,00-1,49$ \\
\hline $1,50-1,99$ & $1,50-1,99$ \\
\hline $2,00-2,99$ & $2,00-2,99$ \\
\hline $3,00-3,99$ & $3,00-3,99$ \\
\hline
\end{tabular}

\subsection{Diamante bruto}

Existem poucas publicações voltadas para a classificação do diamante bruto. De um modo geral, o processo de classificação das pedras brutas leva em conta também as mesmas propriedades já discutidas anteriormente, ou seja a forma, a cor, a granulometria e as imperfeições internas. Na maior parte das tabelas classificatórias o diamante bruto difere do lapidado apenas no item relativo à lapidação, que nesse caso é substituído pela forma geométrica externa. Algumas classificações para o diamante 
bruto podem ser encontradas em Bruton (1984), no Boletim de Preços editado pelo DNPM (DNPM 1991), e em Romboust (1997), entre outros.

Romboust (1997) discute uma tabela produzida através do software TERRAC que baseia-se no mercado livre de Antwerp, a qual avalia os diamantes brutos de forma fácil e prática. Nesse caso, os diamantes são descritos de acordo com a forma, o tipo e a intensidade da cor bem como as inclusões internas. Na classificação da forma são utilizadas as letras $A, B$ e $C$ dependendo das características geométricas externas do diamante. A forma A é usada se o diamante é um cristal único tendo as dimensões segundo os três eixos cristalográficos equidimensionais. Essa categoria refere-se a cristais nas formas de cubo, octaedro e rombododecaedro que são os mais perfeitos possíveis. A forma B é usada quando a pedra é um geminado, usualmente de forma triangular (de contato), um agregado de vários cristais, ou ainda quando a pedra é um cristal único mas não é equidimensional. Neste caso o cristal pode ser um cubo, octaedro, rombododecaedro ou formas associadas distorcidas. A forma $\mathrm{C}$ é usada quando a pedra é muito achatada, assemelhando-se a um geminado de hábito tabular.

Da mesma forma as categorias de cores são designadas por letras, sendo $W$ correspondente a pedras incolores white, $\mathrm{Y}$ a amarelas yellow, $\mathrm{G}$ a verdes green, $\mathrm{E}$ a cinzas grey, B a castanhas brown e $\mathrm{O}$ a qualquer outra cor other. A intensidade de cor varia em uma escala de 0 a 4, na qual o (zero) corresponde à uma pedra incolor, 1 se a cor for somente visível como um matiz fraco, 2 se o matiz for facilmente visível, 3 se a cor for forte e finalmente 4 se a cor for forte tornando a pedra opaca.

A escala correspondente à presença de inclusões e clivagens inicia-se com o número 0 (zero) no caso do cristal ser isento de inclusões e clivagens. Esta escala extende-se até o número 5 se o cristal possuir um grande número de inclusões e/ou clivagens.

Outro sistema classificatório é aquele adotado pelo Boletim de Preços do DNPM, editado regularmente até o ano de 1991, quando foi então desativado. De um modo geral este boletim segue de perto os critérios adotados por Bruton (1978). Apresenta uma tabela de classificação referente a diamante lapidado (Tabela 7.6) e três tabelas para bruto lapidável e bruto industria (Tabelas 7.7, 7.8 e 7.9). Para os diamantes brutos, os parâmetros considerados são a forma (tipo), peso em quilate e a qualidade, que é classificada como extra finest, primeira, segunda e terceira para diamantes lapidáveis e uma quarta para brutos industriais. A classificação da qualidade baseia-se no tipo e no número de defeitos cristalinos internos. 
Tabela 7.6 - Classificação do diamante lapidado (brilhante), baseada na cor e em defeitos cristalinos. Simplificada do Boletim de Preços do DNPM (1991).

\begin{tabular}{|c|c|c|c|c|c|c|}
\hline \multirow{2}{*}{$\begin{array}{c}\text { ESCALA DA } \\
\text { TONALIDADE DE } \\
\text { COR }\end{array}$} & \multirow{2}{*}{$\begin{array}{l}\text { PESO } \\
\mathrm{ct}\end{array}$} & \multicolumn{5}{|c|}{ ESCALA DE PERFEIÇÃO } \\
\hline & & $\begin{array}{l}\text { PERFEITO } \\
\text { LC }\end{array}$ & $\begin{array}{c}\text { IMPERF. } \\
\text { MÍNIMAS } \\
\text { VVSI }, \text { E VVSI }\end{array}$ & $\begin{array}{l}\text { IMPERF. } \\
\text { PEQUENAS } \\
\text { VSI }{ }_{1} \text { e VSI }\end{array}$ & $\begin{array}{l}\text { IMPERF. } \\
\text { MÉDIAS } \\
\text { SI }\end{array}$ & $\begin{array}{l}\text { IMPERF. } \\
\text { GRANDES } \\
P_{1}, P_{2} \in P_{3}\end{array}$ \\
\hline $\begin{array}{l}\text { Excepcionalmente } \\
\text { incolor extra }\end{array}$ & $\begin{array}{l}0,05 \\
1,00 \\
3,00 \\
\end{array}$ & $\begin{array}{r}\text { US\$ } \\
850,00 \\
15,300.00 \\
33,150.00 \\
\end{array}$ & $\begin{array}{c}\text { US } \$ \\
800,00 \\
8,925.00 \\
24,000.00 \\
\end{array}$ & $\begin{array}{r}\text { US } \$ \\
750,00 \\
5,822.00 \\
15,100.00\end{array}$ & US\$ & US\$ \\
\hline $\begin{array}{l}\text { Excepcionalmente } \\
\text { incolor }\end{array}$ & $\begin{array}{l}0,05 \\
1,00 \\
3,00 \\
\end{array}$ & $\begin{array}{r}800.00 \\
9,750.00 \\
25,000.00 \\
\end{array}$ & $\begin{array}{r}750.00 \\
7,300.00 \\
19,550.00 \\
\end{array}$ & $\begin{array}{r}700.00 \\
5,000.00 \\
12,750.00 \\
\end{array}$ & $\begin{array}{r}550.00 \\
3,315.00 \\
8,700.00 \\
\end{array}$ & \\
\hline $\begin{array}{l}\text { Perfeitamente } \\
\text { incolor extra }\end{array}$ & $\begin{array}{l}0,05 \\
1,00 \\
3,00 \\
\end{array}$ & $\begin{array}{r}780,00 \\
8,000.00 \\
22,100.00 \\
\end{array}$ & $\begin{array}{r}700.00 \\
6,000.00 \\
15,300.00 \\
\end{array}$ & $\begin{array}{r}680.00 \\
4,500.00 \\
11,500.00 \\
\end{array}$ & $\begin{array}{r}600.00 \\
3,360.00 \\
8,000.00 \\
\end{array}$ & $\begin{array}{r}400.00 \\
1,785.00 \\
3,000.00 \\
\end{array}$ \\
\hline $\begin{array}{l}\text { Perfeitamente } \\
\text { incolor }\end{array}$ & $\begin{array}{l}0,05 \\
1,00 \\
3,00 \\
\end{array}$ & $\begin{array}{r}700.00 \\
6,550.00 \\
17,000.00 \\
\end{array}$ & $\begin{array}{r}650.00 \\
5,100.00 \\
13,000.00 \\
\end{array}$ & $\begin{array}{r}600.00 \\
4,000.00 \\
10,200.00 \\
\end{array}$ & $\begin{array}{r}550.00 \\
3,180.00 \\
7,225.00 \\
\end{array}$ & $\begin{array}{r}375.00 \\
1,640.00 \\
2,860.00 \\
\end{array}$ \\
\hline Incolor & $\begin{array}{l}0,05 \\
1,00 \\
3,00 \\
\end{array}$ & $\begin{array}{r}680.00 \\
5,000.00 \\
13,175.00 \\
\end{array}$ & $\begin{array}{r}630.00 \\
4,375.00 \\
10,850.00 \\
\end{array}$ & $\begin{array}{r}600.00 \\
3,655.00 \\
8,700.00 \\
\end{array}$ & $\begin{array}{r}500.00 \\
2,975.00 \\
6,375.00 \\
\end{array}$ & $\begin{array}{r}350.00 \\
1,650.00 \\
2,700.00 \\
\end{array}$ \\
\hline Cor perceptível & $\begin{array}{l}0,05 \\
1,00 \\
3,00 \\
\end{array}$ & $\begin{array}{r}650.00 \\
4,250.00 \\
9,800.00 \\
\end{array}$ & $\begin{array}{r}600.00 \\
3,650.00 \\
8,710.00 \\
\end{array}$ & $\begin{array}{r}550.00 \\
3,100.00 \\
7,440.00 \\
\end{array}$ & $\begin{array}{r}480.00 \\
2,670.00 \\
5,820.00 \\
\end{array}$ & $\begin{array}{r}340.00 \\
1,530.00 \\
2,200.00 \\
\end{array}$ \\
\hline Cor visivel & $\begin{array}{l}0,05 \\
1,00 \\
3,00 \\
\end{array}$ & $\begin{array}{r}630.00 \\
3,740.00 \\
8,070.00 \\
\end{array}$ & $\begin{array}{r}570.00 \\
3,270.00 \\
7,430.00 \\
\end{array}$ & $\begin{array}{r}500.00 \\
2,880.00 \\
6,460.00 \\
\end{array}$ & $\begin{array}{r}450.00 \\
2,500.00 \\
5,310.00 \\
\end{array}$ & $\begin{array}{r}330.00 \\
1,440.00 \\
2,350.00 \\
\end{array}$ \\
\hline Cor acentuada & $\begin{array}{l}0,05 \\
1,00 \\
3,00 \\
\end{array}$ & $\begin{array}{r}550.00 \\
3,310.00 \\
6,970.00 \\
\end{array}$ & $\begin{array}{r}510.00 \\
2,970.00 \\
6,330.00 \\
\end{array}$ & $\begin{array}{r}465.00 \\
2,630.00 \\
5,480.00 \\
\end{array}$ & $\begin{array}{r}430.00 \\
2,300.00 \\
4,630.00 \\
\end{array}$ & $\begin{array}{r}300.00 \\
1,360.00 \\
2,200.00 \\
\end{array}$ \\
\hline $\begin{array}{l}\text { Cor levemente } \\
\text { amarelada }\end{array}$ & $\begin{array}{l}0,05 \\
1,00 \\
3,00 \\
\end{array}$ & $\begin{array}{r}500.00 \\
2,970.00 \\
5,250.00 \\
\end{array}$ & $\begin{array}{r}460.00 \\
2,720.00 \\
5,140.00 \\
\end{array}$ & $\begin{array}{r}430.00 \\
2,460.00 \\
4,590.00 \\
\end{array}$ & $\begin{array}{r}400.00 \\
2,080.00 \\
3,740.00 \\
\end{array}$ & $\begin{array}{r}250.00 \\
1,360.00 \\
1,930.00 \\
\end{array}$ \\
\hline Cor amarelada & $\begin{array}{l}0,05 \\
1,00 \\
3,00 \\
\end{array}$ & $\begin{array}{r}415.00 \\
2,300.00 \\
4,200.00 \\
\end{array}$ & $\begin{array}{r}385.00 \\
2,300.00 \\
4,000.00 \\
\end{array}$ & $\begin{array}{r}340.00 \\
2,100.00 \\
3,700.00 \\
\end{array}$ & $\begin{array}{r}300.00 \\
1,720.00 \\
3,000.00 \\
\end{array}$ & $\begin{array}{r}230.00 \\
1,270.00 \\
1,600.00 \\
\end{array}$ \\
\hline Cor amarela & $\begin{array}{l}0,05 \\
1,00 \\
3,00 \\
\end{array}$ & $\begin{array}{r}350.00 \\
1,500.00 \\
3,000.00 \\
\end{array}$ & $\begin{array}{r}320.00 \\
1,300.00 \\
2,750.00 \\
\end{array}$ & $\begin{array}{r}300.00 \\
1,000.00 \\
2,400.00 \\
\end{array}$ & $\begin{array}{r}260.00 \\
800.00 \\
2,000.00 \\
\end{array}$ & $\begin{array}{r}200.00 \\
600.00 \\
1,250.00 \\
\end{array}$ \\
\hline Cor acastanhada & $\begin{array}{l}0,05 \\
1,00 \\
3,00 \\
\end{array}$ & $\begin{array}{r}310.00 \\
1,200.00 \\
2,500.00 \\
\end{array}$ & $\begin{array}{r}300.00 \\
1,000.00 \\
2,250.00\end{array}$ & $\begin{array}{r}250.00 \\
800.00 \\
1,900.00\end{array}$ & $\begin{array}{r}230.00 \\
650.00 \\
1,500.00 \\
\end{array}$ & $\begin{array}{r}170.00 \\
500.00 \\
1,000.00 \\
\end{array}$ \\
\hline
\end{tabular}


Tabela 7.7 - Classificação do diamante bruto lapidável baseada na morfologia e em defeitos cristalinos. Simplificada do Boletim de Preços do DNPM (1991).

\begin{tabular}{|c|c|c|c|c|c|}
\hline \multirow[b]{2}{*}{ TIPO } & PESO & \multicolumn{4}{|c|}{ QUALIDADE } \\
\hline & ct & $\begin{array}{l}\text { EXTRA } \\
\text { "Finest" }\end{array}$ & $\begin{array}{c}\text { PRIMEIRA } \\
\text { "1st" }\end{array}$ & $\begin{array}{l}\text { SEGUNDA } \\
\text { "2nd" }\end{array}$ & $\begin{array}{c}\text { TERCEIRA } \\
\text { " } 3 \mathrm{rd}^{\prime}\end{array}$ \\
\hline \multirow{4}{*}{$\begin{array}{c}\text { octaedros } e \\
\text { rombododecaedros, } \\
\text { inclusive formas } \\
\text { combinadas }\end{array}$} & & US\$ & US\$ & US\$ & US\$ \\
\hline & 0,05 & 150.00 & 125.00 & 100.00 & 70.00 \\
\hline & 1,00 & 400.00 & 300.00 & 235.00 & 150.00 \\
\hline & 3,00 & $2,000.00$ & $1,000.00$ & 700.00 & 400.00 \\
\hline \multirow{3}{*}{$\begin{array}{l}\text { formas irregulares } \\
\text { "irregular shape" }\end{array}$} & 0,07 & 80.00 & 65.00 & 50.00 & 35.00 \\
\hline & 1,00 & 300.00 & 200.00 & 150.00 & 100.00 \\
\hline & 3,00 & $1,800.00$ & 800.00 & 500.00 & 230.00 \\
\hline \multirow{3}{*}{$\begin{array}{l}\text { clivagem } \\
\text { "cleavage" }\end{array}$} & 0,10 & 70.00 & 60.00 & 45.00 & 25.00 \\
\hline & 1,00 & 200.00 & 150.00 & 120.00 & 60.00 \\
\hline & 3,00 & $1,000.00$ & 650.00 & 400.00 & 130.00 \\
\hline \multirow{3}{*}{$\begin{array}{l}\text { triângulos } \\
\text { "macles" }\end{array}$} & 0,10 & 70.00 & 50.00 & 40.00 & 25.00 \\
\hline & 1,00 & 180.00 & 135.00 & 105.00 & 60.00 \\
\hline & 3,00 & $1,000.00$ & 650.00 & 400.00 & 200.00 \\
\hline \multirow{3}{*}{$\begin{array}{l}\text { planos } \\
\text { "flats" }\end{array}$} & 0,20 & 35.00 & 30.00 & 20.00 & \\
\hline & 1,00 & 100.00 & 90.00 & 55.00 & \\
\hline & 3,00 & 350.00 & 220.00 & 160.00 & \\
\hline \multirow{3}{*}{$\begin{array}{c}\text { fragmentos } \\
\text { (pedaços e lascas) } \\
\text { "chips' }\end{array}$} & 0,07 & 25.00 & 18.00 & 15.00 & 10.00 \\
\hline & $\begin{array}{l}1,00 \\
3,00\end{array}$ & $\begin{array}{r}90.00 \\
100.00\end{array}$ & $\begin{array}{l}85.00 \\
95.00\end{array}$ & 70.00 & 40.00 \\
\hline & & & 95.00 & 80.00 & 50.00 \\
\hline
\end{tabular}

Tabela 7.8 - Classificação das formas regulares do diamante bruto do tipo indústria baseada na morfologia e em defeitos cristalinos. Modificada do Boletim de Preços do
DNPM (1991).

\begin{tabular}{|c|c|c|c|c|c|c|c|}
\hline \multirow[b]{2}{*}{ TIPO } & PESO & \multicolumn{6}{|c|}{ QUALIDADE } \\
\hline & $\mathrm{ct}$ & $\begin{array}{l}\text { EXTRA } \\
\text { "Finest" }\end{array}$ & $\begin{array}{l}\text { SUPERIOR } \\
\text { "Fine }\end{array}$ & $\begin{array}{c}\text { PRIMEIRA } \\
\text { "1st" }\end{array}$ & $\begin{array}{c}\text { SEGUNDA } \\
\text { "2nd" }\end{array}$ & $\begin{array}{c}\text { TERCEIRA } \\
\text { "3rd" }\end{array}$ & $\begin{array}{l}\text { QUARTA } \\
\text { "4th" }\end{array}$ \\
\hline $\begin{array}{l}\text { triângulos } \\
\text { "macles" }\end{array}$ & $\begin{array}{l}0,20 \\
1,00 \\
2,50 \\
\end{array}$ & $\begin{array}{c}\text { US } \$ \\
240.00\end{array}$ & US\$ & $\begin{array}{l}\text { US\$ } \\
72.00 \\
144.00 \\
300.00 \\
\end{array}$ & $\begin{array}{l}\text { US } \$ \\
50.00 \\
88.00 \\
110.00 \\
\end{array}$ & US\$ & US\$ \\
\hline $\begin{array}{l}\text { hexaédros } \\
\text { "cubes" }\end{array}$ & $\begin{array}{l}0,25 \\
1,00 \\
2,50 \\
\end{array}$ & & & & & & $\begin{array}{r}8.00 \\
12.00 \\
12.00 \\
\end{array}$ \\
\hline $\begin{array}{l}\text { octaedros } \\
\text { "crystals" }\end{array}$ & $\begin{array}{l}0,05 \\
0,50 \\
1,00 \\
\end{array}$ & & & $\begin{array}{r}30.00 \\
95.00 \\
100.00 \\
\end{array}$ & & & \\
\hline $\begin{array}{l}\text { octaedros } \\
\text { "stones" }\end{array}$ & $\begin{array}{l}0,10 \\
1,00 \\
3,00 \\
\end{array}$ & $\begin{array}{l}325.00 \\
400.00 \\
\end{array}$ & $\begin{array}{l}190.00 \\
225.00 \\
\end{array}$ & $\begin{array}{r}32.00 \\
150.00 \\
175.00 \\
\end{array}$ & $\begin{array}{l}16.00 \\
73.00 \\
84.00 \\
\end{array}$ & $\begin{array}{l}13.00 \\
41.00 \\
41.00 \\
\end{array}$ & $\begin{array}{r}5.00 \\
24.00 \\
24.00 \\
\end{array}$ \\
\hline $\begin{array}{l}\text { rombodeca } \\
\text { edros } \\
\text { "diestones" } \\
\text { (fieiras) }\end{array}$ & $\begin{array}{l}0,05 \\
1,00 \\
3,00\end{array}$ & & & $\begin{array}{l}185.00 \\
325.00 \\
400.00\end{array}$ & $\begin{array}{r}85.00 \\
145.00 \\
176.00\end{array}$ & & \\
\hline
\end{tabular}


A Tabela 7.10 apresenta a classificação comercial de compra e venda de diamantes brutos utilizada atualmente pelos diamantários brasileiros. Esta tabela foi levantada no decorrer do presente trabalho, ocasião em que foram efetuadas diversas visitas a empresas e compradores/vendedores (capangueiros), tanto na cidade de São Paulo como em outros estados, particularmente em Mato Grosso. Trata-se de uma tabela relativamente simples, porém extremamente útil na rotina do mercado de diamantes brutos. Relaciona o número de pedras por quilate e o respectivo peso correspondente, incluindo desde pedras de granulação fina até pedras de vários quilates. Essa tabela se presta tanto para bruto lapidado como para bruto industrial. A tabela não leva em conta aspectos relacionados à cor e à forma porque pressupõe-se que o avaliador domine visualmente estas observações durante a estimativa de preços. O uso da tabela pressupõe que o comprador leve em conta na observação da cor o matiz e a saturação. A experiência é um pré-requisito para que o classificador ou avaliador perceba a eventual existência de diamantes coloridos fancy no lote mesmo que no momento da avaliação não possua nenhuma graduação de cores. No que diz respeito à forma, é necessário um conhecimento sobre lapidação para que o interessado considere a perda em peso que a pedra sofrerá após a sua lapidação.

Outra classificação usada para diamantes gemológicos brutos, na ordem decrescente de tamanho, é a seguinte: pedras; $2 \times 1 ; 3 \times 1$; fazenda fina (15 pedras por ct) e drill (microdiamante) $<2 \mathrm{~mm}$. Esta classificação, assim como as apresentadas anteriormente, requer do avaliador experiência e conhecimento na classifacação das formas e das cores do diamante.

Durante a avaliação dos cristais brutos, dependendo da forma exibida pelo cristal é passível estimar qual o tipo de lapidação bem como o peso que a pedra terá após a sua lapidação. Desta forma, octaedros e rombododecaedros, mesmo contendo algumas inclusões, são mais valiosos do que por exemplo um geminado, o qual por ser achatado e possuir linhas paralelas a subparalelas (costuras), produzirá uma pedra bem menor após sua lapidação. Também é importante durante a avaliação observar o número e a posição das inclusões dentro do cristal. Dependendo do tamanho e da posição, as inclusões podem ser removidas ou então, determinar o corte de um diamante grande em duas ou mais pedras menores. Como o valor final da gema depende também do seu tamanho (peso), verifica-se portanto que as inclusões exercem uma grande influência no preço do diamante lapidado.

Em diamantes brutos, é preciso levar em conta a possibilidade da pedra 
Tabela 7.9 - Classificação das formas irregulares e variedades do diamante bruto do tipo indústria baseada na morfologia e em defeitos cristalinos. Modificada do Boletim de Preços do DNPM (1991).

\begin{tabular}{|c|c|c|c|c|c|c|}
\hline \multirow[b]{2}{*}{ TIPO } & PESO & \multicolumn{5}{|c|}{ QUALIDADE } \\
\hline & ct & $\begin{array}{l}\text { EXTRA } \\
\text { "Finest" }\end{array}$ & $\begin{array}{c}\text { SUPERIOR } \\
\text { "Fine }\end{array}$ & $\begin{array}{c}\text { PRIMEIRA } \\
\text { "1st" }\end{array}$ & $\begin{array}{l}\text { SEGUNDA } \\
\text { "2nd" }\end{array}$ & UNICA \\
\hline $\begin{array}{l}\text { irregulares } \\
\text { "irregular shape" }\end{array}$ & $\begin{array}{l}0,05 \\
1,00 \\
3,00 \\
\end{array}$ & $\begin{array}{l}\text { US\$ } \\
100.00 \\
300.00 \\
325.00 \\
\end{array}$ & US\$ & $\begin{array}{l}\text { US\$ } \\
27.00 \\
143.00 \\
165.00 \\
\end{array}$ & $\begin{array}{r}\text { US\$ } \\
15.00 \\
65.00 \\
65.00\end{array}$ & US\$ \\
\hline $\begin{array}{l}\text { alongados } \\
\text { "elongated" }\end{array}$ & $\begin{array}{l}0,20 \\
1,00 \\
3,00\end{array}$ & $\begin{array}{l}144.00 \\
180.00 \\
264.00 \\
\end{array}$ & & $\begin{array}{r}44.00 \\
132.00 \\
187.00 \\
\end{array}$ & $\begin{array}{l}10.00 \\
40.00 \\
65.00\end{array}$ & \\
\hline $\begin{array}{c}\text { fragmentos } \\
\text { (pedaços e lascas) } \\
\text { "chips" }\end{array}$ & $\begin{array}{l}0,10 \\
0,50 \\
1,00 \\
\end{array}$ & & & $\begin{array}{r}33.00 \\
82.00 \\
100.00 \\
\end{array}$ & $\begin{array}{l}15.00 \\
40.00 \\
40.00 \\
\end{array}$ & \\
\hline $\begin{array}{c}\text { ballas } \\
\text { (esféricos) }\end{array}$ & $\begin{array}{l}0,10 \\
0,50 \\
1,00 \\
\end{array}$ & & & & & $\begin{array}{l}30.00 \\
70.00 \\
70.00 \\
\end{array}$ \\
\hline $\begin{array}{l}\text { carbonados } \\
\text { "carbons" }\end{array}$ & $\begin{array}{l}0,05 \\
1,00 \\
3,00 \\
\end{array}$ & & & & & $\begin{array}{l}4.00 \\
7.00 \\
7.00\end{array}$ \\
\hline $\begin{array}{l}\text { fundo (rejeito) } \\
\text { "boart" }\end{array}$ & & & & & & 2.00 \\
\hline
\end{tabular}

Tabela 7.10 - Classificação comercial de compra e venda de diamantes brutos utilizada no mercado de São Paulo.

\begin{tabular}{|c|c|}
\hline CLASSE & PESO EM ct \\
\hline crivo em 1 & Pedras que passam na peneira 6 \\
\hline fazenda fina & média de 0,10 ct por pedra \\
\hline $4 \times 1$ & $0,25 \mathrm{ct}$ \\
\hline $3 \times 1$ & $0,33 \mathrm{ct}$ \\
\hline $2 \times 1$ & $0,50 \mathrm{ct}$ \\
\hline $3 \times 4$ & $0,75 \mathrm{ct}$ \\
\hline $4 \times 4$ & $1,0 \mathrm{ct}$ \\
\hline $6 \times 4$ & $1,5 \mathrm{ct}$ \\
\hline $8 \times 4$ & $2,0 \mathrm{ct}$ \\
\hline pedras & $>2,0 \mathrm{ct}$ \\
\hline chips & pedaços, pedras mal formadas \\
\hline indústria & cor acentuada, presença de defeitos \\
\hline fundo & grande quantidade de defeitos \\
\hline &
\end{tabular}


apresentar uma capa colorida externa diferente do seu interior. Esse fato é muito freqüente entre diamantes da Serra do Espinhaço, os quais normalmente apresentamse revestidos por uma superfície rugosa de coloração esverdeada. Como o interior desses diamantes é geralmente incolor, após a lapidação obten-se pedras de excelente qualidade no que diz respeito a cor.

\subsection{Classificação gema/indústria do diamante estudado}

Os lotes de diamante bruto foram classificados nos tipos gema e indústria, após uma análise detalhada de todas as suas propriedades físicas tais como granulometria, forma cristalina, intensidade da cor macroscópica, bem como natureza, número e posição dos defeitos tanto internos quanto externos. As pedras foram analisadas individualmente, levando-se em conta os princípios já discutidos nos Capítulos 4, 5 e 6 .

A Tabela 7.11 mostra os dados obtidos no tocante à qualidade (gema e indústria) dos diamantes estudados, abrangendo quatro lotes da região do Alto Paraguai, três da região de Chapada dos Guimarães, dois de Poxoréu e um de Diamantino. Esses dados foram agrupados por regiões e estão ilustrados na Figura 7.3 na forma de diagrama de barras para facilitar a correlação entre as diferentes regiões. Observa-se que existe uma notável semelhança entre as quatro regiões estudadas. Esses resultados concordam com o padrão observado em diversos outros depósitos aluvionares do mundo, onde a proporção de gema é quase sempre superior ao número de indústria.

A Figura 7.4 apresenta um conjunto de histogramas mostrando a relação gema/indústria das principais áreas garimpeiras do Brasil, a saber: Poxoréu, MT (Souza 1991), Diamantina, MG (Chaves 1997), Romaria, MG (Svisero et al. 1981), Tibagi, PR e Juína MT (Svisero 1995), e Chapada Diamantina, BA (Andrade 1999). Em todas as áreas mencionadas predominam diamantes do tipo gema, com exceção dos garimpos de Juína, onde a porcentagem de gemas é baixa. Esse fato pode ser explicado admitindo-se que no caso de Juína, os garimpos estão próximos das áreas fontes. Nesse caso, o diamante foi pouco transportado não tendo havido seleção e eliminação das pedras defeituosas. Apesar de não haver registros oficiais, sabe-se que existem alguns kimberlitos mineralizados na região de Juína, os quais podem ser a fonte do diamante lavrado. Nota-se também, que existe uma proporção menor entre os 
Alto Paraguai (AP1)

Alto Paraguai (AP2)

Alto Paraguai (AP3)

\begin{tabular}{|c|c|c|c|c|c|c|c|c|c|c|c|c|}
\hline Lotes & \multicolumn{2}{|c|}{ gema } & \multicolumn{2}{|c|}{ indústria } & \multicolumn{2}{|c|}{ gema } & \multicolumn{2}{|c|}{ indústria } & \multicolumn{2}{|c|}{ gema } & \multicolumn{2}{|c|}{ industria } \\
\hline $\begin{array}{c}\text { Crivo } \\
\mathrm{mm}\end{array}$ & $\begin{array}{c}\text { peso } \\
\text { ct }\end{array}$ & $\begin{array}{l}\text { núm. } \\
\text { crist. }\end{array}$ & $\begin{array}{l}\text { peso } \\
\text { ct }\end{array}$ & $\begin{array}{l}\text { núm. } \\
\text { crist. }\end{array}$ & $\begin{array}{c}\text { peso } \\
\text { ct }\end{array}$ & $\begin{array}{l}\text { núm. } \\
\text { crist. }\end{array}$ & $\begin{array}{c}\text { peso } \\
\text { ct } \\
\end{array}$ & $\begin{array}{l}\text { núm. } \\
\text { crist. }\end{array}$ & $\begin{array}{c}\text { peso } \\
\text { ct }\end{array}$ & $\begin{array}{l}\text { núm. } \\
\text { crist. }\end{array}$ & $\begin{array}{c}\text { peso } \\
\text { ct }\end{array}$ & $\begin{array}{l}\text { núm. } \\
\text { crist. }\end{array}$ \\
\hline$<$ & 0 & 0 & 0 & 0 & 0 & 0 & 2,22 & 89 & 0 & 0 & 0,30 & 7 \\
\hline 1,7 & 0 & 0 & 0,29 & 8 & 1,71 & 32 & 0,83 & 17 & 0,40 & 8 & 0 & 0 \\
\hline 1,9 & 0,44 & 8 & 0,02 & 1 & 2,40 & 35 & 0,88 & 13 & 0,29 & 4 & 0 & 0 \\
\hline 2,2 & 1,14 & 10 & 0,63 & 6 & 3,24 & 31 & 1,02 & 10 & 1,70 & 15 & 0,24 & 2 \\
\hline 2,5 & 1,29 & 9 & 0,53 & 5 & 3,89 & 26 & 0,81 & 5 & 0,66 & 5 & 0,41 & 3 \\
\hline 2,7 & 3,63 & 19 & 0,57 & 3 & 3,37 & 18 & 0,38 & 2 & 0,54 & 3 & 0 & 0 \\
\hline 3 & 3,41 & 14 & 0 & 이 & 9,45 & 37 & 1,51 & 8 & 0,42 & 2 & 0,69 & 3 \\
\hline 3,3 & 2,17 & 7 & 0 & 0 & 5,06 & 17 & 0,25 & 1 & 0 & 0 & 0 & 0 \\
\hline 3,6 & 4,49 & 11 & 0,68 & 2 & 8,17 & 20 & 0 & 0 & 0,38 & 1 & 0 & 0 \\
\hline 3,9 & 1,3 & 3 & 0 & 0 & 5,16 & 11 & 0 & 0 & 0,39 & 1 & 0 & 0 \\
\hline 4,1 & 0 & 0 & of & of & 2,99 & 5 & 0,52 & 1 & 0 & 0 & o) & 0 \\
\hline 4,3 & 2,29 & 4 & 0 & 0 & 0 & of & 0 & 이 & 0 & 0 & 0 & 0 \\
\hline$>$ & 6,17 & 5 & 0 & 0 & 10,81 & 10 & 0 & 0 & 4,72 & 3 & 0 & 0 \\
\hline total & 26,33 & 90 & 2,72 & 25 & 56,25 & 242 & 8,42 & 146 & 9,5 & 42 & 1,64 & 15 \\
\hline
\end{tabular}

Alto Paraguai (AP4)

\begin{tabular}{|c|c|c|c|c|}
\hline Lote & \multicolumn{2}{|c|}{ gema } & \multicolumn{2}{|c|}{ indústria } \\
\hline $\begin{array}{l}\text { Crivo } \\
\mathrm{mm}\end{array}$ & $\begin{array}{c}\text { peso } \\
\text { ct }\end{array}$ & $\begin{array}{l}\text { núm. } \\
\text { crist. }\end{array}$ & $\begin{array}{c}\text { peso } \\
\text { ct }\end{array}$ & $\begin{array}{l}\text { núm. } \\
\text { crist. }\end{array}$ \\
\hline$<$ & 0 & 0 & 0,65 & 18 \\
\hline 1,7 & 1,88 & 36 & 0 & 0 \\
\hline 1,9 & 2,48 & 35 & 0,26 & 4 \\
\hline 2,2 & 8,88 & 77 & 0 & 0 \\
\hline 2,5 & 10,21 & 69 & 0 & 0 \\
\hline 2,7 & 3,22 & 16 & o) & 0 \\
\hline 3 & 16,24 & 68 & 0,38 & 2 \\
\hline 3,3 & 9,11 & 30 & 1,03 & 4 \\
\hline 3,6 & 16,67 & 42 & 0,72 & 2 \\
\hline 3,9 & 7,85 & 15 & 의 & 0 \\
\hline 4,1 & 13,21 & 22 & 1,15 & 2 \\
\hline 4,3 & 7 & 10 & 0 & 0 \\
\hline$>$ & 28,7 & 27 & 0,87 & 1 \\
\hline total & 125,45 & 447 & 5,06 & 33 \\
\hline
\end{tabular}

Tabela 7.11 - Classificação gema/indústria em função da granulometria dos diamantes estudados neste trabalho. Os dados foram obtidos a partir de quatro lotes da região do Alto Paraguai (AP1, AP2, AP3, AP4), três da Chapada dos Guimarães (CG1, CG2, CG3), dois de Poxoréu(P1, P2) e um de Diamantino (D1). 
Chapada dos Guimarães (CG1) Chapada dos Guimarães (CG2) Chapada dos Guimarães (CG3)

\begin{tabular}{|c|c|c|c|c|c|c|c|c|c|c|c|c|}
\hline Lotes & \multicolumn{2}{|c|}{ gema } & \multicolumn{2}{|c|}{ indústria } & \multicolumn{2}{|c|}{ gema } & \multicolumn{2}{|c|}{ industria } & \multicolumn{2}{|c|}{ gema } & \multicolumn{2}{|c|}{ indústria } \\
\hline $\begin{array}{l}\text { Crivo } \\
\mathrm{mm}\end{array}$ & $\begin{array}{l}\text { peso } \\
\text { ct }\end{array}$ & $\begin{array}{l}\text { núm. } \\
\text { crist. }\end{array}$ & $\begin{array}{c}\text { peso } \\
\text { ct }\end{array}$ & $\begin{array}{l}\text { núm. } \\
\text { crist. }\end{array}$ & $\begin{array}{c}\text { peso } \\
\mathrm{ct}\end{array}$ & $\begin{array}{l}\text { núm. } \\
\text { crist. }\end{array}$ & $\begin{array}{c}\text { peso } \\
\text { ct }\end{array}$ & $\begin{array}{l}\text { núm. } \\
\text { crist. }\end{array}$ & $\begin{array}{l}\text { peso } \\
\text { ct }\end{array}$ & $\begin{array}{l}\text { núm. } \\
\text { crist. }\end{array}$ & $\begin{array}{c}\text { peso } \\
\text { ct }\end{array}$ & $\begin{array}{l}\text { núm. } \\
\text { crist. }\end{array}$ \\
\hline$<$ & $\overline{0}$ & 0 & 이 & 0 & 0 & 0 & 0 & 0 & o) & 0 & 0) & 0 \\
\hline 1,7 & 0 & 0 & 0,32 & 4 & 0,13 & 3 & 0,06 & 1 & 0 & 0 & 0,07 & 2 \\
\hline 1,9 & 0,43 & 6 & 0,45 & 5 & 0,32 & 4 & 0,08 & 1 & 0,29 & 6 & 0,02 & 1 \\
\hline 2,2 & 0,73 & 6 & 0,72 & 6 & 0,77 & 8 & 0 & 0 & 0,57 & 8 & 0,15 & 2 \\
\hline 2,5 & 0,79 & 5 & 0,63 & 4 & 0,31 & 2 & 0,28 & 2 & 1,53 & 16 & 0 & 0 \\
\hline 2,7 & 1,45 & 9 & 0,9 & 4 & 0,40 & 2 & 0 & 0 & \begin{tabular}{l|}
1,43 \\
\end{tabular} & 10 & 0,16 & 1 \\
\hline 3 & 2,55 & 10 & 1,2 & 5 & 1,37 & 6 & 0 & 0 & 0,38 & 2 & 0,51 & 3 \\
\hline 3,3 & 0,34 & 1 & 0,82 & 2 & 0,41 & 1 & 0,26 & 1 & 3,24 & 14 & 0,64 & 3 \\
\hline 3,6 & 0,3 & 1 & 1,46 & 4 & 0,37 & 1 & 0 & of & 2,06 & 7 & 0 & 0 \\
\hline 3,9 & 2,54 & 5 & 0) & 0 & 0 & 0 & 0 & 0 & 3,8 & 10 & 1,02 & 3 \\
\hline 4,1 & 2,84 & 5 & 0 & 0 & 0,63 & 1 & 0 & o & 1,87 & 4 & 0,77 & 2 \\
\hline 4,3 & 8,6 & 8 & 요 & 0 & 0 & 0 & 01 & 0 & 1,31 & 2 & 0 & 0 \\
\hline$>$ & 0 & 0 & of & 이 & 5,69 & 3 & 0 & 0 & 13,51 & 9 & 1,32 & 2 \\
\hline total & 20,57 & 56 & 6,5 & 34 & 10,4 & 31 & 0,68 & 5 & 29,99 & 88 & 4,66 & 10 \\
\hline & & poxore & & & & xoréu & & & & Iamantir & D1) & \\
\hline
\end{tabular}

\begin{tabular}{|c|c|c|c|c|c|c|c|c|c|c|c|c|}
\hline Lotes & \multicolumn{2}{|c|}{ gema } & \multicolumn{2}{|c|}{ indústria } & \multicolumn{2}{|c|}{ gema } & \multicolumn{2}{|c|}{ indústria } & \multicolumn{2}{|c|}{ gema } & \multicolumn{2}{|c|}{ indústria } \\
\hline $\begin{array}{c}\text { Crivo } \\
\mathrm{mm}\end{array}$ & $\begin{array}{c}\text { peso } \\
\text { ct }\end{array}$ & $\begin{array}{l}\text { núm. } \\
\text { crist. }\end{array}$ & $\begin{array}{c}\text { peso } \\
\text { ct }\end{array}$ & $\begin{array}{l}\text { núm. } \\
\text { crist. }\end{array}$ & $\begin{array}{c}\text { peso } \\
\text { ct }\end{array}$ & $\begin{array}{l}\text { núm. } \\
\text { crist. }\end{array}$ & $\begin{array}{c}\text { peso } \\
\text { ct }\end{array}$ & $\begin{array}{l}\text { núm. } \\
\text { crist. }\end{array}$ & $\begin{array}{c}\text { peso } \\
\text { ct }\end{array}$ & $\begin{array}{l}\text { núm. } \\
\text { crist. }\end{array}$ & $\begin{array}{c}\text { peso } \\
\mathrm{ct}\end{array}$ & $\begin{array}{l}\text { núm. } \\
\text { crist. }\end{array}$ \\
\hline$<$ & 0 & 0 & 0,3 & 4 & 0 & 0 & 2,96 & 98 & 0,83 & 23 & 0,38 & 12 \\
\hline 1,7 & 0,4 & 7 & 1,1 & 12 & 1,5 & 29 & 0,65 & 13 & 1,55 & 30 & 0,45 & 10 \\
\hline 1,9 & 1,6 & 16 & 1,2 & 14 & 2,53 & 36 & 0,46 & 7 & 1,29 & 18 & 1,1 & 17 \\
\hline 2,2 & 6,3 & 60 & 1,7 & 18 & 7,42 & 72 & 0,54 & 5 & 5,6 & 54 & 1,44 & 13 \\
\hline 2,5 & 3,6 & 25 & 4 & 27 & 6,36 & 43 & 0 & 0 & 3,34 & 23 & 1,01 & 6 \\
\hline 2,7 & 2,3 & 13 & 0,75 & 5 & 2,13 & 12 & 0,69 & 4 & 1,43 & 8 & 0 & 0 \\
\hline 3 & 7,35 & 30 & 1,2 & 6 & 12,96 & 56 & 0,73 & 4 & 5,27 & 23 & 1,16 & 5 \\
\hline 3,3 & 5,6 & 14 & 1,1 & 4 & 6,84 & 21 & 0 & 0 & 2,85 & 9 & 0 & () \\
\hline 3,6 & 9,05 & 23 & 2,05 & 6 & 8,7 & 21 & 0,44 & 1 & 2,36 & 6 & 1,33 & 4 \\
\hline 3,9 & 4,05 & 8 & 0 & 0 & 5,36 & 10 & 0,8 & 2 & 0,95 & 2 & 0 & 0 \\
\hline 4,1 & 4,1 & 8 & 0,45 & 1 & 7,03 & 11 & o) & 0 & 0,41 & 1 & 0,65 & 1 \\
\hline 4,3 & 5,7 & 7 & 2,75 & 5 & 5,57 & 8 & 0 & 0 & 0,64 & 1 & 0,65 & 1 \\
\hline$>$ & 34,85 & 22 & 1 & 1 & 31,74 & 25 & 1 & 1 & 1,07 & 1 & 0 & 0 \\
\hline total & 84,9 & 233 & 17,6 & 103 & 98,14 & 344 & 8,27 & 135 & 27,59 & 199 & 8,17 & 69 \\
\hline
\end{tabular}




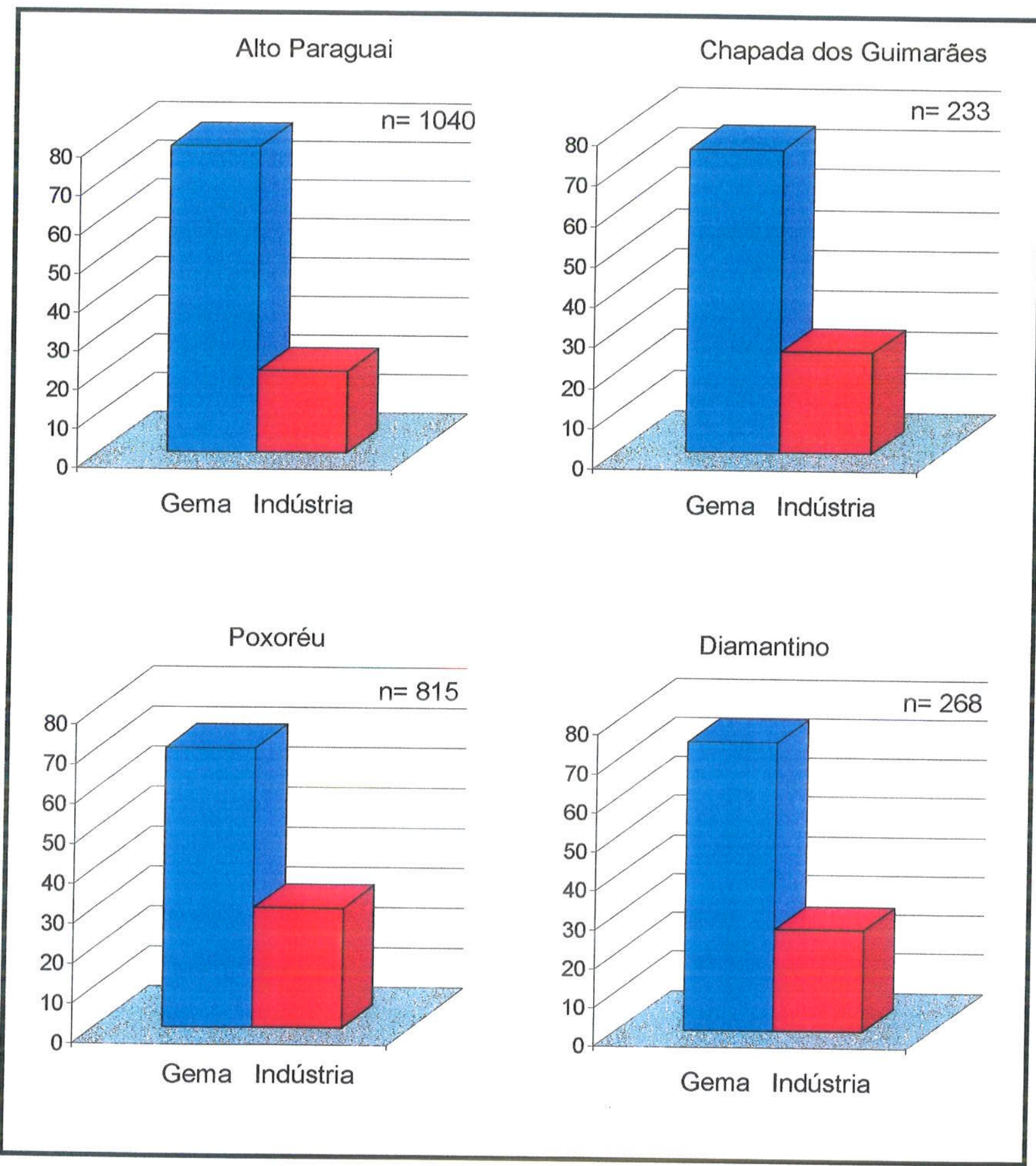

Figura 7.3 - Relação gema/indústria em função da porcentagem de cristais das regiões de Alto Paraguai, Chapada dos Guimarães, Poxoréu e Diamantino. Excetuando-se algumas pequenas diferenças na relação gema/indústria, observa-se uma grande similaridade entre as áreas estudadas. 


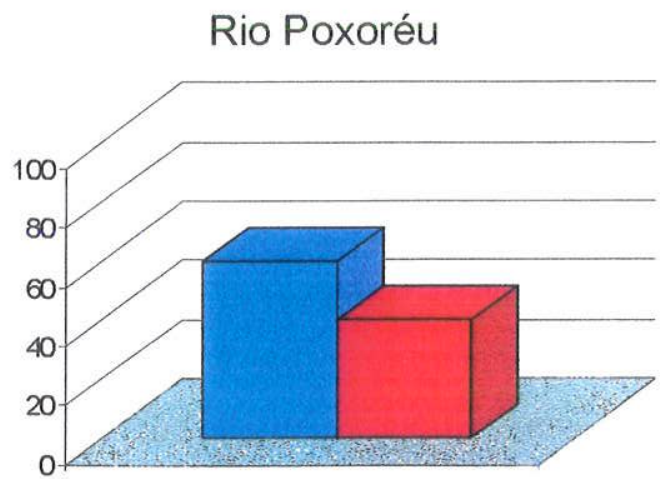

Gema Indústria

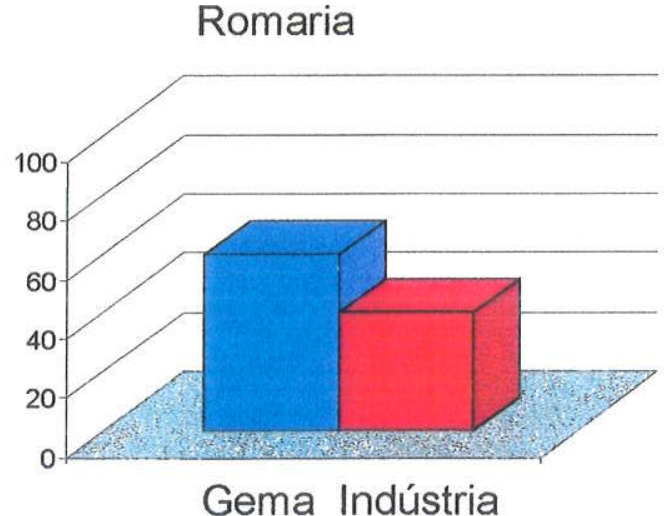

Juína

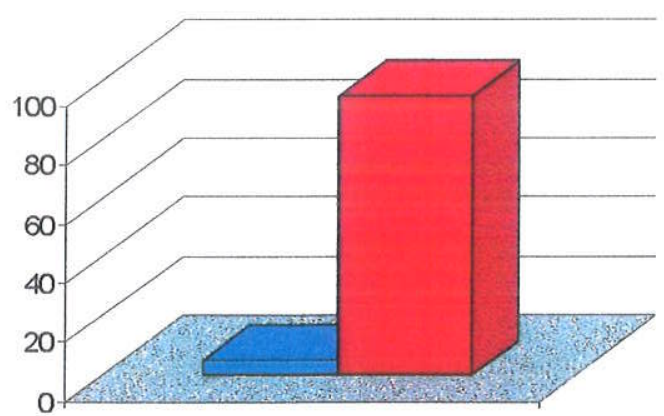

Gema Indústria
Diamantina

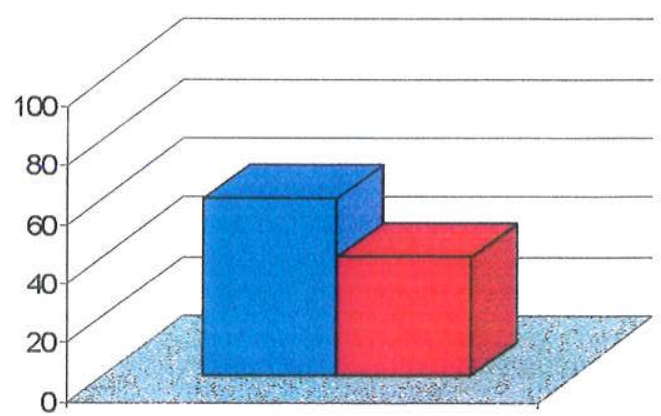

Gema Indústria

Tibagi

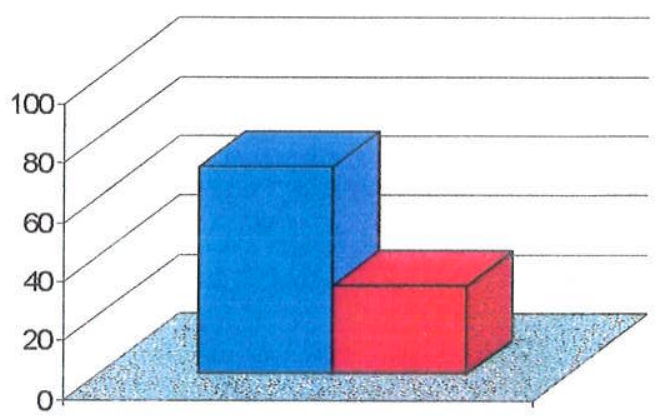

Gema Indústria

\section{Chapada Diamantina}

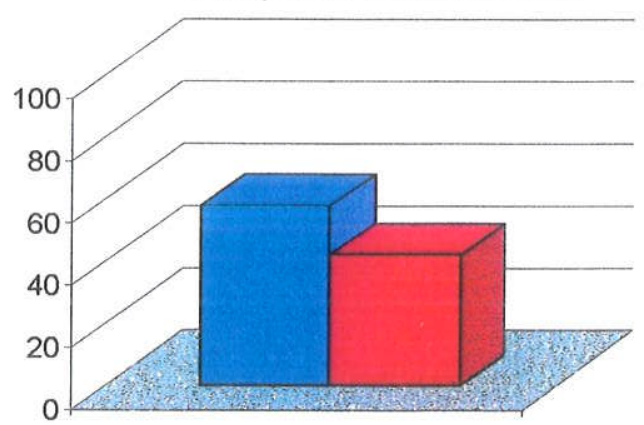

Gema Indústria

Figura 7.4 - Relação gema/indústria em função da porcentagem do número de cristais das principais regiões garimpeiras do Brasil incluindo Rio Poxoréu (Souza 1991), Diamantina (Chaves 1997), Romaria (Svisero et al. 1981), Tibagi e Juína (Svisero 1995) e Chapada Diamantina (Andrade 1999). 
tipos gema e indústria quando comparados com as outras áreas de Mato Grosso estudadas.

Os dados referentes às áreas brasileiras estão reunidos na Tabela 7.12, com informações adicionais de outras regiões do mundo, incluindo também dados de produção e natureza dos depósitos. Com relação a produção, observa-se que a contribuição brasileira é pequena, sendo menor de $1,0 \%$ do montante mundial. Todo diamante brasileiro é de origem detrítica, uma vez que não existe nenhuma mina primária em operação, apesar de já serem conhecidas rochas kimberlíticas mineralizadas em vários locais do país. A Figura 7.5 reúne os histogramas referentes à relação gema/indústria de todas as áreas mencionadas, notando-se características distintas entre os diversos locais. Merece destaque a pequena proporção de gemas nas Minas de Argyle (Austrália) e de Mbuji Mayi (Zaire), tal como observado nos garimpos de Juína. Da mesma forma, destaca-se a grande proporção de gemas mineralizadas nos depósitos marinhos da faixa litorânea da Namíbia e África do Sul (região da Namaqualândia). Esses diamantes foram transportados pelos rios Vaal e Orange ao longo de $1000 \mathrm{~km}$ aproximadamente, desde a região de Kimberley até as praias do Oceano Atlântico. Durante o percurso, os diamantes portadores de defeitos cristalinos foram destruidos, permanecendo os diamantes gemológicos que são aqueles destituídos de defeitos físicos (clivagens, inclusões, policristalinos, etc.). 
Tabela 7.12 - Relação gema/indústria, produçäo e tipo de depósito das principais regiōes diamantíferas do Brasil e do mundo.

\begin{tabular}{|c|c|c|c|c|c|c|}
\hline País & Localidade & Gema & Indústria & $\begin{array}{l}\text { Produção total } \\
(1998) \times 10^{6} \mathrm{ct}^{*}\end{array}$ & Observações & Referências \\
\hline \multirow{6}{*}{ Brasil } & Romaria, MG & 60 & 40 & \multirow{6}{*}{1,0} & $\begin{array}{c}\text { Conglomerados } \\
\text { Cretáceos }\end{array}$ & Svisero et al. (1981) \\
\hline & Poxoréu, MT & 60 & 40 & & \multirow{5}{*}{ Aluviões modernos } & Souza (1991) \\
\hline & $\frac{\text { Diamantina, } M G}{\text { Tibagi } \mathrm{PR}}$ & 60 & 40 & & & Chaves (1997) \\
\hline & $\begin{array}{l}\text { Tibagi, PR } \\
\text { Juína, MT }\end{array}$ & 70 & 30 & & & Svisero (1995) \\
\hline & $\frac{\text { Juína, MT }}{\text { Chapada }}$ & 10 & 90 & & & \\
\hline & Diamantina & & & & & Andrade (1999) \\
\hline \multirow{3}{*}{ África do Sul } & Premier & 20 & 80 & \multirow{3}{*}{9,1} & Kimberlito & \multirow{10}{*}{ Levinson (1998) } \\
\hline & Finsch & 20 & 80 & & Kimberlito & \\
\hline & Venetia & 40 & 60 & & Kimberlito & \\
\hline Austrália & Argyle & 5 & 95 & 108 & & \\
\hline \multirow{2}{*}{ Rússia } & Mir Zarnitsae & & & 40,0 & Lamproito & \\
\hline & Udachnaya & $20 / 25$ & $75 / 80$ & 40,8 & Kimberlito & \\
\hline Botswana & $\begin{array}{c}\text { Orapa, Jwaneng, } \\
\text { Letchakane }\end{array}$ & 40 & 60 & 16,8 & Kimberlito & \\
\hline Angola & Lunda Norte & 70 & 30 & 1,9 & Aluviōes modernos & \\
\hline Zaire & Mbuji-Mayi & 5 & 95 & 20,0 & Aluviões modernos & \\
\hline $\begin{array}{c}\text { Namíbia-África } \\
\text { do Sul }\end{array}$ & Namaqualândia & $90 / 95$ & $5 / 10$ & 1,3 & Aluviões modernos & \\
\hline
\end{tabular}




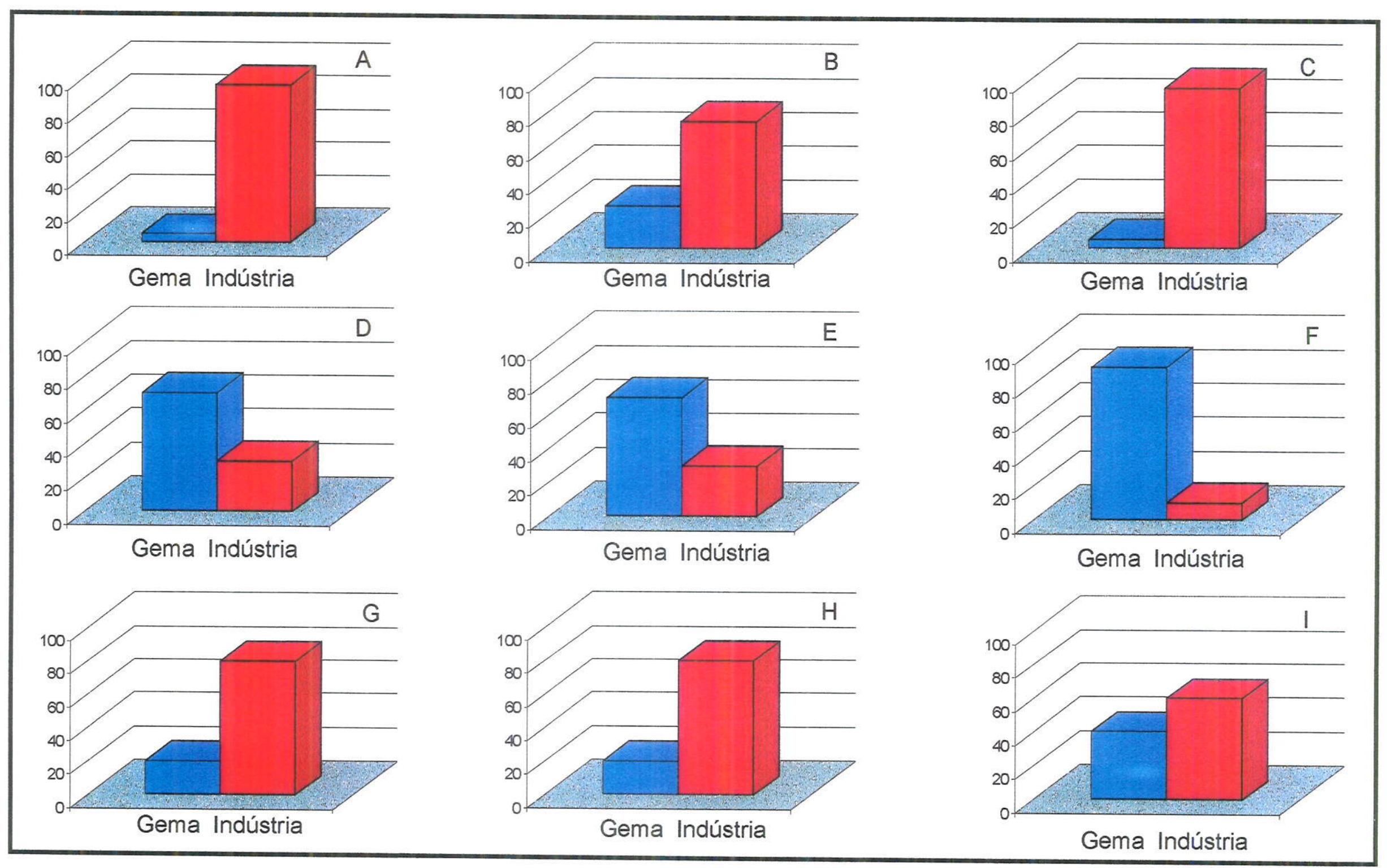

Figura 7.5 - Relação gema/indústria das principais minas de diamante do mundo: A)Argyle (Austrália); B) Mir, Zarnitsa e Udachnaya (Rússia); C) Mbuji Mayi (Zaire); D) Orapa, Jwaneneg e Letchakane (Botswana); E) Lunda Norte (Angola); F) depósitos marinhos NamíbialÁfrica do Sul; G) Premier, H) Finsch e I)Venetia (África do Sul). 


\section{REFERÊNCIAS BIBLIOGRÁFICAS}

ABREU, S.F. (1973) Diamante. In:__. Recursos minerais do Brasil. 2.ed. São Paulo, Edgard Blücher/EDUSP. v. 1, p. 237-308.

ABREU, S.F. (1975) Diamante. In: A riqueza mineral do Brasil. 2.ed. São Paulo. Nacional/ Brasiliana. p.100-115.

ALMEIDA, F.F.M. DE (1954) Geologia do Centro-leste Matogrossense. Boletim.Divisão de Geologia e Mineralogia. Departamento Nacional de Produção Mineral. Rio de Janeiro, n.150, p.1-97.

ALMEIDA, F.F.M. DE (1964) Geologia do Centro-leste Matogrossense. Boletim.Divisão de Geologia e Mineralogia. Departamento Nacional de Produção. Mineral. Rio de Janeiro, n.215, p.1-133.

ALMEIDA, F.F.M. DE (1984) Província Tocantins - setor sudeste. In: ALMEIDA F.F.M. DE ; HASUI, Y. (coords.). O Pré-Cambriano no Brasil. São Paulo, Edgard Blücher, p. 265-281.

ALMEIDA, F.F.M. DE; HASUI, Y. (1984) O embasamento da Plataforma Sul-americana, In: ALMEIDA F.F.M. DE; HASUI, Y. (coords.). O Pré-Cambriano no Brasil. São Paulo, Edgard Blücher, p. 1-5.

ALMEIDA, F.F.M. DE ; MANTOVANI, M.S.M. (1975) Geologia e geocronologia do Granito de São Vicente, Mato Grosso. Anais da Academia Brasileira de Ciências. Rio de Janeiro, v.47, n.3/4 p.451-458.

ALVARENGA, C.J.S. (1988) Turbiditos e a glaciação do final do proterozóico superior no cinturão Paraguai, Mato grosso. Revista Brasileira de Geociências, v.18, n.3, p. 323-327. 
ALVARENGA, C.J.S. (1990) Phenomenes sedimentaires, structuraux et circulation de fluides developpes a la transition chaine-craton - exemple de la Chaine Paraguai d'age Proterozoique Superieur, Mato Grosso, Brésil. Marseille, France. 177p. Thèse (Doctorat) - Université de Droit, d'Econimie et des Sciences d'Aix-Marseille.

ALVARENGA, C.J.S.; TROMPETTE, R. (1992) Glacial influeced sedimentation in the uppermost proterozoic and lower Cambrian of the Paraguai belt (Mato Grosso, Brazil). Paleogeography Paleoclimatology Paleoecology, v.92, p. 85-105.

ALVARENGA, C.J.S.; TROMPETTE, R. (1994) A Faixa Paraguai e a sua compartimentação estratigráfica e tectônica. In: CONGRESSO BRASILEIRO DE GEOLOGIA, 38., Camboriú, 1994. Boletim de Resumos Expandidos. Camboriú, SBG. v.1, p. 239-240.

ALVARENGA, C.J.S. DE; SAES, G.S. (1992) Estratigrafia e sedimentologia do Proterozóico Médio e Superior da região sudeste do Cráton Amazônico. Revista Brasileira de Geociências, v.22, n.4, p. 493-499.

ANDRADE, C.M. (1999) Aspectos mineralógicos, geológicos e econômicos de diamantes carbonado da Chapada Diamantina, Bahia. São Paulo, 359p. Dissertação (Mestrado) - Instituto de Geociências, Universidade de São Paulo.

ASSINE, M.L., PETRI, S. (1994) Caracterização faciológica da Formação Furnas no Estado do Paraná. In: , CONGRESSO BRASILEIRO DE GEOLOGIA, 39., Salvador, 1994. Boletim de Resumos Expandidos. Salvador, SBG. v.1, p. 242-244.

ASSOCIAÇÃO BRASILEIRA DE NORMAS TECNICAS -ABNT- (1991). Diamante lapidado. (NB-1394/1991).

BAKON, A.; SZYMANSKI, A. (1993) Practical uses of diamond. New York, Ellis Horwood, 248p.

BARBOSA, O. (1938) O diamante Minas Gerais. Mineração e Metalurgia. v.3, n.14, p. 69. 
BARBOSA, O. (1991) Diamante no Brasit: histórico, ocorrência, prospecção e lavra. Brasília, CPRM. 136p.

BARROS, A. M.; DA SILVA, R. H.; CARDOSO, O. R. F. A.; FREIRE, F. A.; DE SOUZA JR., J. J.; RIVETTI, M.; DA LUZ, O. S.; PALMEIRA, R. C. DE B.; TASSINARI, C. C. G. (1982) Geologia. In: Projeto RADAMBRASIL. Folha SD-21 Cuiabá. Rio de Janeiro, MME/DNPM. p.67-138. (Levantamento de Recursos Naturais, 26).

BATISTA, S.N. (1991) Depósitos diamantíferos de Poxoréu-MT. In: SCHOBBENHAUS, C.E.S.C.(coord.). Principais depósitos Minerais do Brasil. Brasília, DNPM-CPRM. v. 4-A, p. 149-154.

BAUER, M.; LARGHER, G.N. (1958) A preliminary report of the eastern central part of the State of Mato Grosso and a portion of the western part of the state of Goiás, Brazil, Ponta Grossa. In: DEBSP. Petrobrás. (Relatório Técnico Interno, 837).

BAXTER, M. (1988) Garimpeiros de Poxoréu: mineradores de pequena escala de diamantes e seu meio ambiente no Brasil. Brasília, Centro Gráfico do Senado Federal. $301 \mathrm{p}$.

BERGAMACHI, S. (1994) Aspectos faciológicos do devoniano inferior da Bacia do Paraná na faixa de afloramentos do flanco norte do arco estrutural de Ponta Grossa. In: CONGRESSO BRASILEIRO DE GEOLOGIA, 38., Camboriú, 1994. Boletim de Resumos Expandidos. Camboriu, SBG. v. 1, p. 88-89.

BEURLEN, K.A. (1956) A geologia pós-algonquiana do sul do Estado de Mato Grosso. Boletim. Divisão de Geologia e Mineralogia. Departamento Nacional de Produção Mineral. Rio de Janeiro, n. 163, p.1-137.

BOGGIANI, P.C. (1997) Análise estratigráfica da Bacia Corumbá (neoproterozóico) Mato grosso do Sul. São Paulo, 181p. Tese (Doutorado) - Instituto de Geociências, Universidade de São Paulo. 
BORGHI, L. (1998) Megaondulações produzidas por marés de tempestade na Formação Furnas (Silurio-Devoniano, da Bacia do Paraná). In: CONGRESSO BRASILEIRO DE GEOLOGIA, 40., Belo Horizonte, 1998. Anais. Belo Horizonte, SBG. p.107.

BRAGG, W. H.; BRAGG, W. L. (1913) The structure of diamond. Proceedings Royal Society. London. v. 89A, p.1-277.

BRUTON, E. (1978) Diamonds. 2 ed. Radnor, Chilton Book. 532p.

BURSILL, L.A.; GLAISHER, R.W. (1985) Aggregation and dissolution of small and extended structures in Type la diamond. American Mineralogists, v.70, p. 608-618.

CAMPOS, J.G.; GONZAGA, G.M. (1999) O transporte de diamantes por sistemas fluviais a longas distâncias: uma visão crítica. Revista Brasileira de Geociências, v.29, n. 2, p. 113-118.

CARVALHO, M. S. DE; AKABANE, T.; TESSER, M.A.; DA S. FILHO, L.T. (1991) Depósito de diamante da Fazenda Camargo, Nortelândia, Mato Grosso. In: SCHOBBENHAUS, C.E.S.C.(coord.). Principais depósitos minerais do Brasil. Brasília, DNPM-CVRD. v. 4-A, p. 161-176.

CASTELNAU, F. (1949) Expedição às regiões centrais da América do Sul. São Paulo, Nacional. 2v. p. 30-35.

CHAVES, M.L.S.C. (1997) Geologia e mineralogia do diamante da Serra do Espinhaço em Minas Gerais. São Paulo, 285p. Tese (Doutorado) - Instituto de Geociências, Universidade de São Paulo.

CHAVES, M.L.S.C.; DUPONT, H.; KARFUNKEL, J.; SVISERO, D.P. (1993) Depósitos diamantíferos de Minas Gerais: uma revisão. In: SIMPÓSIO BRASILEIRO DE GEOLOGIA DO DIAMANTE, 1., Cuiabá, 1993. Anais. Cuiabá, UFMT. p. 79-100. 
CHIEREGATI, L.A. (1989) Aspectos mineralógicos, genéticos e econômicos das ocorrências diamantíferas da região nordeste do Paraná e sul de São Paulo. São Paulo, 180p. Dissertação (Mestrado) - Instituto de Geociências, Universidade de São Paulo.

CLARK, C.D.; MITCHEL, E.W.J.; PARSONS, B.J. (1979) Colour centres optical properties. In: FIELD, J.E. (ed.). The properties of diamond. London, Academic Press. p. 23-77.

COLLINS, A.T. (1982) Colour centres in diamond. Journal of Gemmology, v.18, p. 3775.

COIMBRA, A.M. (1991) Antéclise de Rondonópolis, In: Sistematização crítica da obra. São Paulo, p.28-54. Tese (Livre Docente) - Instituto de Geociências, Universidade de São Paulo.

CORDANI, U.G.; BRITO NEVES, B.B.; FUCK, R.A.; PORTO, R.; THOMAS FILHO, A.; CUNHA, F.M.B. (1984) Estudo preliminar de integração do pré-Cambriano com os eventos tectônicos das bacias sedimentares brasileiras. Revista Ciência Técnica Petróleo, n. 15, p. 12-20.

CORRÊA, J.A.; CORREIA, FILHO, F.C.L.; SCISLEWSKI, G.; NETO, C.; CAVALLON, L.A.; CERQUEIRA, N.L.S.; NOGUEIRA, V.L. (1976) Geologia das regiões do Centro e Oeste de Mato Grosso: Projeto Bodoquena. Brasília, DNPM/CPRM. 111p.

COSTA, V.S. (1996) Estudo mineralógico e químico do kimberlito Batovi 6 (MT) em comparações com as intrusões Três Ranchos 4 (GO) e Limeira (MG). Campinas, 112p. Dissertação (Mestrado) - Instituto de Geociências, Universidade Estadual de Campinas.

DAVIES, R.; GRIFFIN, W.L.; PEASON, N.J.; ANDREW, A.; DOYLE, B.J.; O'REILLY, S.Y. (1998) Diamonds from the Deep: Pipe DO-27, Slave Craton, Canada. In: INTERNATIONAL KIMBERLITH CONFERENCE, 7., Cape Town, South Africa, 1998. Extended Abstracts. South Africa, GSSA/IAGC/SEG/SGA. p. 170-172. 
DAVIS, W.J.; KJARSGAARD, B.A. (1997) A Rb-Sr isochron age for a kimberlite from the recently discovered Lac de Gras field, Slave Province, Northwest Canada. Journal of Geology, v. 105, p. 503-509.

DAWSON, J.B. (1980) Kimberlites and their xenoliths. Springer Verlag. 252p.

DERBY, O. A. (1911) A notable brazilian diamond. American Journal of Science, v. 32, p. 191-194.

DEUTSCH, C.V.; JOURNEL, A.G. (1996) GSLIB: Geostatistical software library and user's guide. 2.ed. Oxford, University Press. 360p.

DNPM (1991). Diamante natural. Sumário Mineral. Departamento Nacional da Produção Mineral, v.11, p.44-45.

DNPM (1998). Diamante. Sumário Mineral. Departamento Nacional da Produção, v.18, p. $42-43$.

DRAGO, V.A.; PINTO, A.C.; DE MONTALVÃO, R.M.G.; DOS SANTOS, R.O.B.; SIMÕES, M.A.; OLIVEIRA, I.C.; BEZERRA, P.E.L.; PRADO, P.; FERNANDES, C.A.C.; TASSINARI, C.C.G. (1981) Geologia. In: Projeto RADAMBRASIL. Folha SD22 Goiás. Rio de Janeiro, MME/DNPM. p.102-211. (Levantamento de Recursos Naturais, 25).

EPPLER, W.F. (1961). Inclusions in diamond. Journal of Gemmology, v.8, p.1-3.

FERSMAN, A. VON; GOLDSHIMIDT, V. (1911) Der diamant. Heidelberg, Carl Winters. $274 p$.

FIGUEIREDO, A.J. DE A.; OLIVATTI, O. (1974) Projeto ALTO GUAPORÉ: relatório final integrado. Goiânia, DNPM/CPRM. v. 11, 173p. 
FILEMON, K.E.;JESUS, I.P.S.; WESKA, R.K. (1997) Intrusão kimberlítica Piranhas I ParanatingamT. In: SIMPÓSIO DE GEOLOGIA DO CENTRO-OESTE, 6. Cuiabá,Mato Grosso, 1997. Anais. Cuiabá, UFMT. p. 109-110.

FRAGOMENI, P.R.P. (1976) Controle tectônico da província kimberlítica de Paranatinga. Boletim. Informativo da Sociedade Brasileira de Geologia Goiânia. Núcleo Centro-Oeste. v.5, p. $3-10$.

FRITZEN, C.L.; LIVI, R.P.; SOUZA, J.P.; JORNADA, J.A. (1997) Changes in the CVD diamond nucleation density of scratched Si substrates due to ion implantation. Diamond Films and Technology, v.7, n. 1, p. 49-59.

FRITSCH, E. (1998) The nature of color in diamonds. In: HARLOW, G.E. (ed.) The nature of diamonds. London, Cambridge University Press. p. 23-47.

GEMOLOGICAL INSTITUTE OF AMERICA (1991). Diamond grading. 4.ed. Santa Monica, Gemological Institute of America. v.1

GESICKI, A.L.D.; RICCOMINI, C.; BOGGIANI, P.C.; COIMBRA, A.M. (1996) Evidências do avanço glacial na Formação Aquidauana (Neopaleozóico da Bacia do Paraná) no Estado de Mato Grosso do Sul. In: CONGRESSO BRASILEIRO, 39. Salvador, 1996. Anais. Salvador, SBG. v.1, p.124-127.

GIBSON, S.A.; THOMPSON, R.N.; WESKA, R.K.; DICKIN, A.P. ; LEONARDOS, O.H. (1997) Late Cretaceous rift-related upwelling and melting of the Trindade starting mantle plume head beneath western Brazil. Contributions to Mineralogy and Petrology, v.126, p. 303-314.

GOLDSCHMIDT, V. (1916) Diamant. In__. Atlas der krystallformen. Heidelberg, Carls Winters. p. 28-48.

GOLDSTEIN, J.I.: NEWBURY, D.E.; ECHIN, P.; JOY, D.C.; ROMING, JR., A.D.; LYMAN, C.E.; FIORI, G.L. (1994) Scaning electron microscopy and x-ray 
microanalysis: a tex for biologists, materials scientists, and geologists. 2.ed. New York, Plenum Press. 820p.

GONÇALVES, A.; SCHNEIDER, R.L. (1970) Geologia do centro-leste de Mato Grosso, Ponta Grossa. In: DESUL. Rio de Janeiro, Petrobrás. 43p. (Relatório Técnico Interno, n.394).

GONZAGA, G.M.; TOMPKINS, L.A. (1991) Geologia do diamante. In: SCHOBBENHAUS, C.E.S.C. (coord.). Principais depósitos minerais do Brasil. Brasília, DNPM-CPRM. v.4-A. p. 53-116.

GREENWOOD, J.C.; GIBSON, S. A.; THOMPSON, R.N.; WESKA, R.K.; DICKIN, A.P. (1998) Petrogensis of Cretaceous kimberlites from the Paranatinga region, Central Brazil, In: INTERNATIONAL KINBERLITE CONFERENCE, 7., Cape Town, South Africa, 1998. Extended Abstracts. South Africa, Geological Society of South Africa. p. 268-270.

GUIMARÃES, G.; ALMEIDA, L.F.G. de (1972). Projeto CUIABÁ: relatório final. Departamento Nacional da Produção Mineral, Cuiabá. (Relatório do Arquivo Técnico, n. 1872).

GUIRRO, A.C. (1991) Análise de fácies dos sedimentos da Formação Aquidauana (Neocarbonífero) no sudeste de Mato Grosso e nos poços da borda norte da Bacia do Paraná, Ouro Preto, MG. Ouro Preto, 187p. Dissertação (Mestrado) Departamento de Geologia de Minas, Universidade Federal de Ouro Preto.

GURNEY, J.J. (1989) Diamond. In: KIMBERLITES AND RELATED ROCK / INTERNATIONAL KIMBERLITE CONFERENCE, 4., Perth, 1986. Proceedings. Carlton, Blackwell Scientific. v.2, p.935-965. (GSA Special Publication, n.14).

GUBELIN, E.J.; KOIVULA, J.I. (1992) Photoatlas of inclusions in gemstones. 2.ed. Zurich, ABC. 532p. 
HAGGERTY, S.E. (1995). Upper mantle mineralogy. Journal of Geodynamics, v.20, p.331-364.

HAGGERTY, S.E. (1999) A diamond trilogy: superplumes, supercontinents, and supernoval. Science, v.285, n.5429, p. 851-860.

HALL, A.E.; SMITH, C.B. (1984) Lamproite diamond - are they different? In: GLOVER, J. E.; HARRIS, P.G. (eds.). Kimberlith occurrence and origin: a basis for conceptual models in exploration. Perth, Universith of Western Australia. p.167-205. (University Extention Publication 8).

HEAMAN, L.; TEXEIRA, N.A .; GOBBO, L.; GASPAR, J.C. (1998) U.Pb mantle zircon Ages for kimberlites from the Juina Paranatinga Provinces, Brasil. In: INTERNATIONAL KIMBERLITH CONFERENCE, 7., Cape Town, South Africa, 1998. Extended Abstracts. South Africa, GSSA/IAGC/SEG/SGA. p. 322.

HARRIS, J.W. (1968) The recognition of diamond inclusions. Syngenetie mineral inclusions. Industrial Diamond Review, n.28 p. 402-410;.558-561.

HARRIS, J.W. (1987) Recente physical, chemical and isotopic research of diamonds, In: NIXON, P.H. (ed.). Mantle xenoliths. Chichester, John Wiley \& Sons. p. $477-$ 500.

HARRIS, J.W.; GURNEY, J.J. (1979) Inclusions in diamond. In: Physical properties of diamond, J.E.Field Editor, Academic Press, London, p. 555-592,

HARRIS, J.W.; HAWTHORNE, J.B.; OOSTERVELD, M.M. (1979) Regional and local variation in the characteristics of diamonds from some southern African Kimberlites. In: BOYD, F.R.; MEYER, H.O.A. (eds.). Kimberlites diatremes and diamonds: their geology, petrology and geochemistry. Washington, Americam Geophysical Union. p. $27-41$. 
HARRIS,J.W.; HAWTHORNE, J.B.; OOSTERVELD, M.M.; WEHMEYER, E. (1975) A classification schene for diamond and a comparative study of south african diamond characteristics. Physics and Chemistry of the Earth, v.9, p. 765-783.

HARRIS,J.W.; HAWTHORNE, J.B.; OOSTERVELD, M.M. (1984) A comparison of diamond characteristics from the De Beers pool mines, Kimberley, South Africa. In: KIMBERLITES / INTERNATIONAL KIMBERLITE CONFERENCE, 3., ClermontFerrand, France, 1982. Proceedings. Amsterdam, Elsevier. v. 1, p. 1-13.

HASSUI, Y;; ALMEIDA, F.F.M. de (1970) Geocronologia do centro-oeste brasileiro. Boletim. Sociedade Brasileira Geologia, v.19, n.1, p. 5-26.

HENNIES, W.T. (1966) Geologia do centro-norte mato-grossense. São Paulo, 65p. Tese ( Doutorado) - Escola Politecnica, Universidade de São Paulo.

HOEL P.G. (1963) Estatística elementar. Rio de Janeiro, Fundo de Cultura. 311p.

JANSE, A.J.A. (1995). A history of diamond sources in Africa: part I. Gems \& Gemmology, v.31, n.4, p.228-255.

JOSWIG, W.; STACHEL, T.; HARRIS, J.W.; BAUER, W.H.; BREY, G.P.(1999) New Casilicate inclusions in diamonds traders from the lower mantle. Earth and Planetary Science Letters, v.173, p.1-6.

KAISER W.; BOND W.L. (1959) Nitrogen, a major impurity in common type I diamond. Physics Review, v. 115, p. 857-863.

KAMINSKIY, F.V. (1994) Carbonado and yakutite: properties and possible genesis. In: INTERNATIONAL KIMBERLITE CONFERENCE, 5., Araxá, Brasil, 1991. Proceedings. Rio de Janeiro, CPRM. v. 2, p. 136-143.

KING, J.M.; MOSES, T.M.; SHIGLEY, J.E.; LIU, Y. (1994) Color grading of colored diamonds in the GIA Gem Trade Laboratory. Gems \& Gemology, v 30, n.4, p.220242. 
LEINZ, V. (1939) O diamante Presidente Vargas. Mineração e Metalurgia, v.4, n.21, p. 185-186.

LEITE, C.R. (1969) Mineralogia e cristalografia do diamante do Triângulo Mineiro. São Paulo, 102p. Tese (Doutorado) - Faculdade de Filosofia Ciências e Letras, Universidade de São Paulo.

LEONARDOS, O.H. (1956) Recursos minerais do triângulo mineiro. Mineração e Metalurgia, n.140, p.71-77.

LEONARDOS, O.H; SALDANHA, R. (1939) Diamante "Darcy Vargas" e outros grandes diamantes brasileiros. Boletim.Faculdade Filosofia Ciências e Letras. Universidade de São Paulo. Série Mineralogia, v.18, n.3, p. 3-25.

LENZEN, G. (1983) Diamand and diamond grading. London, Butterworth . 258p.

LEVINSON, A.A. (1998) Diamond sources and their discovery. In: HARLOW, G.E. The nature of diamonds. New York, Cambridge University. p.72-115.

LEVINSON, A.A.; GURNEY, J.J.; KIRKLEY, M.B. (1992) Diamond sources and production: past, present, and future. Gems \& Gemology, v. 28, p. 234-254.

LUZ, J. DA S.; ARAÚJO, E.S.; GODOI, H. de O. (1980) Projéto COXIPÓ: relatório final. Goiânia, Departamento Nacional de Produção Mineral/Companhia de Recursos Minerais. v.1, 136p.

MCCALLUM, M.E.; HANTLEY, P.M.; FALK, R.W.; OTTER, M.L. (1994) Morphological, resortion and etch feature trends of diamonds from kimberlite populations within the Colorado - Wyoming State Line district, USA. In: INTERNATIONAL KIMBERLITE CONFERENCE, 5., Araxá, Brasil, 1991. Proceedings. Rio de Janeiro, CPRM. p. 32 50.

MCCALLUM, M.E.; MABARAK, C.D.; COOPERSMITH, H.G. (1979) Diamonds from kimberlite, in the Colorado, Wyoming State Line district. In:BOYD, F.R.; MEYER, 
H.O.A. (eds.). Kimberlites diatremes and diamonds: their geology, petrology and geochemistry. Washington, American Geophysical Union. p. 42-58.

MENDELSSHON, M.J.; MILLEDGE, H.J. (1995) - Morphological characteristics of diamond populations in relation to temperature-dependent growth and dissolution rates. International Geology Review, v. 37, p. 285-312.

MEYER, H.O. A. (1985) Genesis of diamond: a mantle saga. Americam Mineralogist, v. 70, p. $344-355$.

MEYER, H.O.A. (1987). Inclusions in diamond. In: NIXON, P.H. Mantle xenoliths. New York, John Wiley \& Sons. p. 501-522.

MEYER, H.O.A.; TSAI, H.M. (1976a) Mineral inclusion in natural diamond: their nature and significance. Minerals Science Engineering, v.8, p. 242-261.

MILANI, E.J. (1994) Bacia do Paraná. Boletim de Geociências da Petrobrás, v.8, n.1, p. 69-82.

MILANI, E.J.; RAMOS A.V. (1998) Orogenias paleozóicas no domínio sul-ocidental do Gondwana e os ciclos de subsidências da Bacia do Paraná. Revista Brasileira de geociências, v. 28, n. 4, p. 473-484.

MITCHELL, R.H. (1986) Kimberlites: mineralogy, geochemistry and petrology. New York, Plenum Press. 442p.

MOORE, M.; LANG, A.R. (1974) On the origin of the rounded rhombic dodecahedral habit of natural diamond. Journal Crystalography Growth, v.26, p. 133-139.

MOREIRA, M.I. (1998) Deformações glaciogênicas na Formação Vila Maria (siluriano, Bacia do Paraná). In: CONGRESSO BRASILEIRO DE GEOLOGIA, 40., Belo Horizonte, 1998. Boletim de Resumos Expandidos. Belo Horizonte, SBG. p.98 
MOSES, T.M.; REINITZ, I.M.; JOHSON, M.L.; KING, J.M.; SHIGLEY, J.E. (1997) A contribution to understanding the effect of blue fluorescence on the appearance of diamonds. Gems \& Gemology, v.33, n. 4, p.244-259.

MÜHLMANN, H. (1974) Revisão estratigráfica da Bacia do Paraná, Ponta Grossa. In: DESUL. Petrobrás, 186p. (Relatório Técnico Interno, n.444).

MÜLLER, G. (1967) Methods in sedimentary petrography (part 1). New York, Hafner. 283p.

MUNSELL COLOR COMPANY (1976). Munsell book of color: mattle finish collection. Baltimore, Munsell Collor. (ASTM Committee D-1 on Paint and related coatings and material. Standard method of specifying color by the Munsell system). v. 1-2.

NASSAU, K. (1976) A origem da cor dos minerais e das gemas. Gemologia, v.22, n. 43-44, p. 17-52 .

NASSAU, K. (1983) Physics and chemistry of color. New York, John Wiley \& Sons. 454p.

NASSAU, K.; McCLURE, S.F.; ELEN, S.; SHIGLEY, J.E. (1997). Synthetic moissanite: a new diamond substitute. Gems \& Gemmology, v.33, p.260-275.

NIXON, P.H. (1987) mantle xenoliths, John Wiley \& Sons, New York, 844p.

NOGUEIRA, V.L.; OLIVEIRA, C.C.; FIGUEIREDO, J.A.; CORREAA FILHO, F.C.L.; SCISLEWSKI, N.G.; SOUZA, M.R.; MORAES FILHO, J.C.R.; LEITE, E.A.; SOUZA, N.B.; SOUZA, J.O.; CERQUEIRA, N.L.S.; VANDERLEI, A.A.; TAKASCHI, A.T.; ABREU FILHO, W.; ROSITO, J.; OLIVATTI, O.; HAUSEN, J.E.P.; GONÇALVES, G.N.D.; RAMALHO, R.; PEREIRA, L.C.B. (1978). In: Projeto BONITOAQUIDAUANA - relatório final. Goiânia, DNPM/CPRM. $14 \mathrm{v}$. (Relatório do Arquivo Técnico, n. 2744). 
NORTHFLEET, A.A.; MEDEIROS, R.R.; MUHLMANN, H. (1969) Reavaliação dos dados geológicos da Bacia do Paraná. Boletim Técnico da Petrobrás, v.12, n.3, p. 291-343.

OLIVATTI, O. (1981) Problemas estratigráficos do Pré-Cambriano na região sudoeste do Estado de Mato Grosso - tentativa de correlação com a geologia do oriente boliviano. In: SIMPÓSIO DE GEOLOGIA DO CENTRO-OESTE, 1., Goiânia,1981. Atas. Goiânia, SBG. p. 196-211.

OLIVATTI, O.; RIBEIRO FILHO, W. (1976) Revisão da geologia do centro-norte de Mato Grosso. In: Projeto CENTRO-OESTE DE MATO GROSSO, ALTO GUAPORÉ E SERRA AZUL. Goiânia, Departamento Nacional da produção Mineral/Companhia de Pesquisa de Recursos Minerais. 51 p.

OLIVEIRA, A.I. DE ; LEONARDOS, O.H. (1943) Geologia do Brasil. 2.ed. Rio de Janeiro, Serviço de Informação Agrícola, 813p. (Série Didática, 2).

OLIVEIRA, M.A.M. DE ; MÜLHMANN, H. (1965) Geologia de semi-detalhe da região de Mutum, Jaciara, São Vicente e Chapada dos Guimarães. In: DEBSP. Ponta Grossa, Petrobrás. 62p. (Relatório Técnico Interno, n.300).

ORLOV, Y.L. (1966). Evidence that the rounding of diamons is caused by a dissolution process. Min. Sbor. Lwousk. Univ., v.20, p.129-134.

ORLOV, Y.L. (1977) The mineralogy of the diamond. New York, Wiley \& Sons. $235 p$.

OTTER, M.L.; MCCALLUM, M.E.; GURNEY, J.J. (1994) A physical characterization of the Sloan (Colorado) diamonds using a comprehensive diamond description scheme. In: INTERNATIONAL KIMBERLITE CONFERENCE, 5., Araxa, Brasil, 1991. Proceedings. Rio de Janeiro, CPRM. p. 15-31

PAGEL-THEISEN, V. (1986). Diamond grading: handbook for diamond grading. New York, Rubin \& Son. 275p. 
PAL'IYANOV, YU. N.; KHOKHRYAKOV, A.F.; BORZDOV, YU.M.; SOKOL, A.G. (1995) On the role of water in growth and dissolution of diamond Abs. 8 International Symposium on Water-Rock Interactions, $4 p$.

PERIN, A.L. (1993) Beneficiamento de cascalho diamantífero com alto teor de limonitas. In: SIMPÓSIO BRASILEIRO DE GEOLOGIA DO DIAMANTE, 1., Cuiabá, Mato Grosso. Anais. Mato Grosso, UFMT. p.199-207p.

PICCIRILLO, E.M.; MELFI, A.J. (1988) The mesozoic flood volcanism of the Paraná basin: petrogenetic and geophysical aspects. São Paulo, Instituto Astronômico e Geofísico. 600p.

PETRI, S.; FÚlFARO, V.J. (1983) Geologia do Brasil. São Paulo, Editora da Universidade de São Paulo. 631p.

PETTIJOHN, F.J. (1957) Sedimentary rocks. New York, Harper \& Row. 718p.

POPP, J.H.; POPP, M.B. (1986) Análise estratigráfica da seqüência deposicional devoniana da Bacia do Paraná (Brasil). Revista Brasileira de Geociências, v.16, n.2, p.187-194.

QUITETE, E.B.; COUTINHO, J.M.V.; RODRIGUES, E.P. (1994) Metodologia para identificação de diamantes lapidados do laboratório de certificação gemológica do IPT em Franca, SP. In: CONGRESSO BRASILEIRO DE GEOLOGIA, 38., Camboriú, 1994. Anais. Camboriú, SBG. p. 196-198.

REIS, E. (1959) Os grandes diamantes brasileiros. Boletim. Departamento Nacional da Produção Mineral. Divisão de Geologia e Mineralogia, n.191, p.1-65.

RIBEIRO FILHO, W.; LUZ, J. DA S.; ABREU FILHO, W. (1975). Projeto Serra Azul: relatório final. Departamento Nacional da Produção Mineral/Companhia de Pesquisa de Recursos Minerais. v. 1, $104 \mathrm{p}$. 
RICHARDSON, S.H.;GURNEY, J.J.; ERLANK, A. J.; HARRIS, J.W. (1984). Origin of diamonds in old enriched mantle. Nature, v.310, p.198-202.

ROBERTSON, R.; FOX J.J.; MARTIN, A.E. (1934) Two types of diamond. Philosophical Transactions Royal Society, v.232-A, p. 463-535.

ROMBOUTS (1995) Size and value distributions of diamonds. In: INTERNATIONAL KIMBERLITE CONFERENCE, 6., Russia, 1995. Extended Abstracts. Russia, UIGGM. p. 470-472.

ROMBOUTS, L. (1997) The evaluation of diamond depositis. In: BRAZILIAN DIAMOND SYMPOSIUM, 2., Cuiabá, 1997. Anais. 42p.

ROSA, D.B.; WESKA, R.K.; LIMA, P.R.M. (1993) Sobre certas formas de sílicas fibrosas associadas as mineralizações diamantíferas na região de Água fria, Município de Chapada dos Guimarães, MT. In: SIMPÓSIO BRASILEIRO DE GEOLOGIA DO DIAMANTE, 1., Cuiabá, Mato Grosso, 1993. Anais. Mato Grosso, UFMT. p. 152-163.

SALDANHA, R. (1941) O diamante Coromandel. Boletim. Faculdade Filosofia Ciências e Letras. Universidade de São Paulo, n.21, p.15-23.

SALDANHA, R. (1942) O diamante Governador Valadares. Boletim.Faculdade de Filosofia Ciências e Letras. Universidade de São Paulo. Série Mineralogia, n.5, p. 17-23.

SCHNEIDER, R.L.; MÜHLMANN, H.; TOMMASI, E.; MEDEIROS, R.A.; DAEMON, R.F.; NOGUEIRA, A.A. (1974) revisão estratigráfica da Bacia do Paraná, In: CONGRESSO BRASILEIRO DE GEOLOGIA, 28., Porto Alegre, 1974. Anais. Porto Alegre, SBG. v.1, p. 41-65.

SCHOBBENHAUS, C.; CAMPOS, A.D.; DERZE, G.R.; ASMUS, H.E. (1984) Geologia do Brasil: texto explicativo do mapa geológico do Brasil e da área oceânica 
adjacente incluindo depósitos minerais na escala 1:2 500 000. Brasília, DNPM. $501 p$.

SCHUBERT, G. (1994) Estratigrafia e sistemas deposicionais do devoniano da Bacia do Paraná na Borda NW, região de Chapada dos Guimarães - MT. In: CONGRESSO BRASILEIRO DE GEOLOGIA, 38., Camboriú, 1994. Boletim de Resumos Expandidos. Camboriú, SBG. v.1, p.92-94.

SILVA, G.D. DA; SILVA, J.A. DA; KATO, S.L.R.; OLIVEIRA, L.J. DE; COUTINHO, W.M.; ARAÚJO, S.A. DE ; BARROS, M.V.P. DE; MASSARI, V.M.; PAULA, J.P. de (1997) Levantamento das atividades mineradoras na sub-bacia do Alto Rio Paraguai, Mato Grosso. In: SIMPÓSIO BRASILEIRO DE GEOLOGIA DO DIAMANTE, 2., Cuiabá, Mato Grosso. Programas, Resumos, Palestras e Roteiro de Excursão. Cuiabá, UFMT. p. 47-48.

SIQUEIRA, L.P. de, (1989) Bacia dos Parecis. Boletim de Geociências da Petrobrás, v. 3, n. $1 / 2$, p. 3-16.

SIQUEIRA, L.P. DE; TEIXEIRA , L.P. (1993) Bacia dos Parecis: nova fronteira exploratória da Petrobrás. In: CONGRESSO INTERNACIONAL DA SOCIEDADE BRASILEIRA DE GEOFíSICA, 3., São Paulo, 1993. Expanded Absiracts. São Paulo, SBGF. v. 1, p. 168-173.

SMITH, C.B.; GURNEY, J.J.; SKINNER, E.M.W.; CLEMENT, C.R.; EBRAHIM, N. (1985) Gheochimical character of southern african kimberlites - a new approach based on isotopic constrains. Transactions Geological Society of South Africa, v. 88, n.2, p. $267-280$.

SOARES, P.C.; BAGGIO, S.B. (1994) Formação Botucatu: geometria, fácies elétricas e indicadores paleotectônicos. In: CONGRESSO BRASILEIRO DE GEOLOGIA, 38., Camboriú, 1994. Boletim de Resumos Expandidos. Camboriú, SBG. v. 1, p. 96-97. 
SOUZA, J.L. (1984) Diamante: propriedades, classificação e reconhecimento. Ouro Preto, Centro Gemológico do Departamento de Geologia da Universidade Federal de Ouro Preto. 55p.

SOUZA N.B. (1991) depósitos diamantíferos de Poxoréu, Mato Grosso. In: SCHOBBENHAUS, C.E.S.C. (coord.) Principais depósitos do Brasil. Brasília, DNPM/CVRD. V.4-A, p. 149-154.

SUNAGAWA, I. (1984) Morphology of natural and synthetic diamond crystals. In: Materials science of the earth's interior. Tokyo, Terra Scientific. p. $303-330$.

SUNDARAN, D.; QUADROS, R.; FERNANDES, A.V.L. (1997) A ocorrência de uma assembléia faunística (Malviocráfica) da Formação Ponta Grossa na borda norte da Bacia do Paraná. In: SIMPÓSIO DE GEOLOGIA DO CENTRO-OESTE, 6., Cuiabá, MaTo Grosso, 1997. Anais. Mato Grosso, UFMT. 83p.

SUTHERLAND, D.G. (1982) The transport and sorting of diamonds by fluvial and marine processes. Economic Geology, v. 77, n. 7, p. 1613-1620.

SUTTON, J. R. (1928) Diamond: a descriptive treatise. London, T. Murby. 118p.

SVISERO, D. P. (1971) Mineralogia do diamante da região de Alto Araguaia, MT. São Paulo, 137p. Tese (Doutorado) - Instituto Geofisico e Astronômico, Universidade de São Paulo.

SVISERO, D.P. (1984) Inclusões de diamantes naturais: uma revisão. Anais do $34^{\circ}$ Congresso Brasileiro de Geologia, v.11, p. 4954-4961.

SVISERO, D.P. (1995) Distribution and origin of diamond in Brasil: an overview. Journal of Geodynamics, v. 20 p. $493-514$.

SVISERO, D.P.; HARALY, N.L.E. (1978) O diamante Princesa Estrela do Sul. Mineração e Metalurgia, v. 42, n. 405, p. 38-41. 
SVISERO, D.P.; HARALYI, N.L.E. (1985) Caracterização do diamante da Mina de Romaria, Minas Gerais. In: SIMPÓSIO DE GEOLOGIA DE MINAS GERAIS, 3., Belo Horizonte, 1985. Anais. Belo Horizonte, SBG-MG. p. 140-153.

SVISERO, D.P.; FELITTI FILHO, W.; ALMEIDA, J.S. (1981) Geologia da mina de diamante de Romaria, Município de Romaria, MG. Mineração e Metalurgia, n. 425, p. 4-14.

SVISERO, D.P.; MEYER, H.O.A. (1986) New ocorrence of kimberlites in Brazil. In: Kimberlites and related rocks: their composition, occurrence origin and emplacement / INTERNATIONAL KIMBERLITE CONFERENCE, 4., Perth, Australia, Proceedings. Carlton, Blackwell Scientific. V.1, p. 145-147.

SVISERO, D.P.; ZOLINGER, I.T. (2000) Morfologia de diamantes da região da Serra da Canastra, Minas Gerais. (em preparação).

TOLANSKY, S. (1960). Surface microtopography. London, Longman. 296p.

TOLANSKY, S. (1965) Optical studies on diamonds. In: BERMAN, R. (ed.). Physical properties of diamond. Oxford, Claredon Press. p. 135-166.

TRAUTMAN, R.; GRIFFIN, B.E.; SCHARF, D. (1998) Microdiamonds. Scientific American, v.279, n.2, p. 62-67.

TRAUTMAN, R.; GRIFFIN, B. E.; TAYLOR, W.R.; SPETSIUS, Z.V.; SMITH, C.B.; LEE, D.C. (1997) A comparison of the microdiamonds from kimberlite and lamproite of Yakutia and Australia. Russian Geology and Geophysics, v. 38, n. 2, p. 341-355.

VAN DER VEEN, A. L. W. E. (1913) Die symmetrie der diamanten. Zentralblatt fur Krisallographie und Mineralogie, v.51, p.545-590.

VIEIRA, A.J. (1965) A geologia do centro-oeste de Mato grosso, Ponta Grossa. In: DEBSP. Petrobrás. 79p. (Relatório Técnico Interno, n.303). 
WESKA, R.K. (1987) "Placers"diamantíferos da região de Água Fria - Chapada dos Guimarães, MT. Brasília, 170p. Dissertação ( Mestrado) - Universidade de Brasília.

WESKA, R.K. (1996a) Geologia da região diamantífera de Poxoréu e áreas adjacentes, Mato Grosso. São Paulo, 219p. Tese (Doutorado) - Instituto de Geociências, Universidade de São Paulo.

WESKA, R.K. (1996b) A prospecção aluvionar de diamantes a partir do entendimento de armadilhas "traps". In: CONGRESSO BRASILEIRO DE GEOLOGIA, 39., Salvador, 1996. Anais. Salvador, SBG. p.189-191.

WESKA, R. K.; BITTENCOURT, R. D.; PISANI, J.R.T.; ARRAIS, J.C. DE P.; MACIEL, M. A. C.; RIBEIRO, J.M.; KATO, S.L.R.; ARAUJO, S.A. DE; ROSESTOLATO, F.A. (1993) A estratigrafia, a evolução tectônica e o diamante do Grupo Bauru da região de Poxoréu, MT, Brasil. In: SIMPÓSIO BRASILEIRO DE GEOLOGIA DO DIAMANTE, 1., Cuiabá, MT, 1993. Anais. Cuiabá, UFMT. p. 208228.

WESKA, R.K.; DANNI, J.C.M.; DARDENNE, M.A.; PERIN, A.L. (1988) Contribuição à estratigrafia do Grupo Bauru da Chapada dos Guimarães, MT, In: CONGRESSO BRASILEIRO DE GEOLOGIA, 35., Belém, 1988. Anais. Belém, SBG-Núcleo CentroOeste. v.1, p.200-210.

WESKA, R.K.; PERIN, L.A.; FERREIRA, I.A. (1984) Placers diamantíferos da bacia do Alto Paraguai-MT, Caracterização geológica como critérios e guias de prospecção, In: CONGRESSO BRASILEIRO DE GEOLOGIA, 33., Rio de Janeiro, 1984. Anais. Rio de Janeiro, Sociedade Brasileira de Geologia. v. 8, p. 3877-87.

WESKA, R.K.; PERIN, A.L.; ROSA, D.B. (1991) "Placers"diamantíferos na Chapada dos Guimarães - Mato Grosso - Brasil. In: SIMPÓSIO DE GEOLOGIA DO CENTRO-OESTE, 3., Cuiabá-Mato Grosso , 1991. Anais. Cuiabá, UFMT. p. 200206. 
WESKA, R.K.; SVISERO, D.P. (1997) Microdiamante na intrusão Tamburi, região de Poxoréu, Mato Grosso. In: SIMPÓsIO BRASILEIRO DE GEOLOGIA DO DIAMANTE, 2., Cuiabá, Mato Grosso, 1997. Programas, Resumos, Palestras e Roteiro de Excursão. Cuiabá, UFMT. p. 37-38.

WESKA, R.K.; SVISERO, D.P.; LEONARDOS, O.H. (1996) Contribuição ao conhecimento do Grupo Bauru no Estado de Mato Grosso, Brasil. In: SIMPÓsıO SOBRE O CRETÁCEO DO BRASIL, 4., Rio Claro, 1996. Anais. UNESP, Campus de Rio Claro, p. 289-295.

WHITE, I.C., (1908) Relatório final da comissão das minas de carvão de pedra do Brasil. Rio de Janeiro, Imprensa Nacional. 607p.

WHITELOCK, T.K. (1973) Morphology of the Kao diamonds. In: Nixon, P. H. (ed.). Lesotho kimberlites. Lesotho National Development. p. 128-140.

WILLIAM, A.F. (1932) The genesis of diamond. London, Ernest Benm. 536p.

WILDING, M.C.; HARTE, B.; HARRIS, J.W. (1991). Evidence for a deep origin of São Luís diamonds. In: INTERNATIONAL KIMBERLITE CONFERENCE, 5., Araxá, 1991. Extended Abstracts. Brasilia, CPRM. p.456-458.

WILKS, E \& WILKS, J. (1994) Properties and applications of diamond. ButterworthHeinemann Ltd, London, 525p.Robinson, D.N.; Scott, J.A.; van Niekerk, A. e Anderson, V.G. (1989) The sequences of events reflected in the diamonds of some Southern African kimberlites. In: Kimberlites and Related Rocks. v.2 Their Mantle/Crust Stting Diamonds and Diamond exploration: 990-1000.

YACOOT, A.; MOORE, M. (1993) X-ray topography of natural tetrahedral diamonds. Mineralogical Magazine, v. 57, p. 223-230.

YURK, Y. Y. (1966) Crystallomorfhology and physical properties of diamonds from Ukraine placer deposits. Min. Sbor. Luovsk. Univ., v.20, p. 490-497. 
ZALÁN, P.V.; WOLF, S.; CONCEIÇÃO, J.C.J.; MARQUES, A.; ASTOLFI, M.A.M.; VIEIRA, I.S.; APPI, V.T.; ZANNOTO, O.A. (1990) Bacia do Paraná. In: GABAGLIA, G.P.R.; MILANI, E.J. (coords.) Origem e evolução de bacias sedimentares. Rio de Janeiro, Petróleo Brasileiro/SDRH/SDRHS. p. 135-168. 